\title{
AMERICAN JEWRY AND THE OSLO YEARS
}

\section{By}

Neil Rubin

A thesis presented to the faculty of

\section{Towson University}

In partial fulfillment

Of the requirements for the degree

Doctor of Philosophy in

Judaic Studies

May 2010

Towson University

Towson, Maryland 21252 
(C) By Neil Rubin

All Rights Reserved 


\section{Abstract \\ American Jewry and the Oslo Years \\ Neil Rubin}

By the early 1990s the themes binding American Jewish life were experiencing irrevocable change. Formal emigration and religious barriers for Jews in the former Soviet Union had ended. The task of commemorating the Holocaust was entrenched. Finally, the 1993 IsraeliPLO signing of the Olso Accords seriously challenged American Jewry's unity in politically defending an embattled Israel. Meanwhile, mounting internal American Jewish communal concerns included confronting intermarriage, declining Jewish identity measurements, and rising tensions between Orthodox and non-Orthodox Jews over Israeli government attempts to redefine the "Who is a Jew?" issue. At the same time, membership groups declined, the influence of "mega-donors" rose, and the sense being in a collective community weakened.

By the end of the Oslo period and the start of the Second Intifada, American Jewish groups quickly again rushed to defend Israel, but they found an overall smaller, less interested and more divided community than in the past. 


\section{Table of Contents}

\section{Chapter I. Introduction to the Study}

I.1 Rise and Fall of the Oslo Accords 1

I.2 How Oslo Changed American Jewry 6

I.3 American Jewry's Pre-Oslo Triumphs and Challenges 12

$\begin{array}{ll}\text { I.4 Oslo's Opportunities and Crises } & 20\end{array}$

I.5 Rationale For This Research Project 26

I.6 Research Materials and Resources 31

\section{Chapter II. U.S. Jewry on the Eve of Oslo}

II.1 The Importance of American Jewry in the U.S. Political Landscape 35

II.2 A Disproportionate Influence on the Electorate 40

II.3 Israel on the Agenda $\quad 42$

II.4 The 1967 Revolution 46

II.5 Fighting for Political Loyalties $\quad 50$

II.6 Loan Guarantee Battles 52

II.7 American Jewry's Awkward Position 57

II.8 George H.W. Bush's Strategic Error 60

II.9 Baker Outrages American Jews 62

II.10 Rabin Becomes Prime Minister $\quad 64$

II.11 Intermarriage and a 'Continuity' Agenda 66

II.12 Distancing and Dissent on Israel $\quad 70$

$\begin{array}{ll}\text { II.13 Rising Religious Politics } & 74\end{array}$

$\begin{array}{ll}\text { II.14 A Holocaust Agenda Achieved } & 75\end{array}$

\section{Chapter III. The Rabin-Peres Years}

III.1 How Washington Became Israel's Top Ally 79

$\begin{array}{lll}\text { III.2 The Rabin-Clinton Bond } & 85\end{array}$

III.3 Rabin's Rocky Relationship With American Jews 88

III.4 Washington and the Oslo Accords 93

III.5 American Jewry's Response to the Oslo Accords 95

III.6 A Post-Oslo American Jewish Agenda 97

III.7 Tensions Within Organized Jewish Life 103

$\begin{array}{lll}\text { III.8 Orthodox and Non-Orthodox Divide } & 106\end{array}$

III.9 Washington's Response to Rabin Assassination 108 
III.10 Rabin Assassination and American Jews

\section{Chapter IV. The Netanyahu Years}

IV.1 Post-Rabin Assassination to Wye 116

$\begin{array}{lll} & 125\end{array}$

IV.3 Netanyahu, American Jews, and the Conversion Crisis 128

$\begin{array}{ll}\text { IV.4 Netanyahu's Addresses to the G.A. } & 135\end{array}$

IV.5 American Jewish, American Catholic Ties Grow 139

IV.6 Strains With Mainstream Protestants 141

$\begin{array}{lll}\text { IV.7 An Evangelical Alliance } & 144\end{array}$

IV.8 Shifts in American Jewry's Attachment to Israel 149

IV.9 Changes in American Jewish Identity 153

IV.10 Israel At 50: American Jews Take Stock 156

IV.11 Netanyahu Loses Power 159

\section{Chapter V. The Barak Years}

V.1 From Camp David II to Intifada II 162

$\begin{array}{ll}\text { V.2 Negotiations Jumpstarted } & 166\end{array}$

$\begin{array}{lll}\text { V.3 Camp David to Intifada } & 168\end{array}$

V.4 The Al-Aksa Intifada 172

V.5 Barak and American Jews 176

$\begin{array}{lll}\text { V.6 Pluralism and Peace } & 180\end{array}$

$\begin{array}{lll}\text { V.7 Confronting an Israel At Peace } & 185\end{array}$

V.8 Population Surveys and Jewish Interests 188

V.9 Spirituality and Religious Shifts 194

V.10 The Impact of the Camp David Failure 199

V.11 American Jews and the Al-Aksa Intifada 202

$\begin{array}{ll}\text { V.12 Media Monitoring } & 207\end{array}$

V.13 Breakdown of Ties With American Arab Groups 211

V.14 A Changed American Jewry 214

\section{Chapter VI. Conclusions}

VI.1 Lessons for American Jews 220

VI.2 Lessons for Israeli Governments 224

VI.3 An Era of Broad Shifts $\quad 227$

VI.4 How it All Happened 229

$\begin{array}{lll}\text { VI.5 Shifting Priorities } & 230\end{array}$

VI.6 Jewish Political Power 235 
VI.7 Why the Pro-Israel Agenda Matters 237

VI.8 The Shock of Oslo $\quad 240$

VI.9 A Move Inward 246

VI.10 New Efforts at American Jewish-Israeli Ties 248

VI.11 Response to Rabin Assassination 249

$\begin{array}{ll}\text { VI.12 Netanyahu's Tenure } & 251\end{array}$

VI.13 Lessons From the Conversion Crisis 252

VI.14 Camp David II Talks and Renewed Violence 254

$\begin{array}{ll}\text { VI.15 Final Thoughts } & 258\end{array}$

Selected Bibliography and Sources $\quad 260$

$\begin{array}{ll}\text { Curriculum Vita } & 281\end{array}$ 


\section{Chapter I. Introduction to the Study}

\section{I.1 Rise And Fall of The Oslo Accords}

The general sense of optimism surging through the Jewish and diplomatic world on September 13, 1993 clearly rivaled that of other key moments in modern Jewish history, included heralded events such as David Ben-Gurion's much-anticipated proclamation of Israeli statehood on March 14, 1948, and the seemingly miraculous success of the Arab-Israeli Six Day War (June 5-10, 1967).

Yet, the first event was tempered by the belief even amongst top Israeli military officials that the fledgling Jewish state's survival was uncertain, which meant the pending battles could result in a newly acute refugee crisis, not to mention tens of thousands of dead Jews, including Holocaust survivors who had recently arrived from Europe's emptying Displaced Persons (DP) camps. ${ }^{1}$ The joyous relief greeting the second event was preceded by weeks of fear of imminent attack by a numerically overwhelming multinational Arab force that might launch a "second Holocaust." after the Six-Day War, a few veteran Israeli political leaders as well as Diaspora activists

\footnotetext{
${ }^{1}$ On May 12, 1948, Yigal Yadin, head of military operations during Israel's War of Independence, told Ben-Gurion and other pre-state leaders in a lengthy briefing that, among other things: the situation in Jerusalem remained extremely critical; the Jordanian Legion had overwhelmed the Etzion bloc of settlements; and the Arab forces' numbers of weapons were superior as were their numbers of troops. He personally preferred a truce because even if manpower and weapons could come in quickly after May 15, when the British would formally no longer control the country, the chances of a successful defense were even. Howard M. Sachar, A History of Israel From the Rise of Zionism to Our Time (New York: Alfred A. Knopf, 2007 ) pp. 310-311.

${ }^{2}$ Before the war, Israel Defense Forces (IDF) Chief of Staff Yitzhak Rabin instructed schools and public buildings to be readied as hospitals and 10 rabbis from the chief rabbinate went through public parks, sanctifying them as cemeteries. Rabin told cabinet minister Zerah Warhaftig that the IDF could suffer "tens of thousands" of soldiers killed in combat. As the author and journalist Tom Segev has since written, "Only a society drenched in the memory of the Holocaust could have prepared so meticulously for the next one." Tom Segev, 1967: Israel, the War, and the Year that Transformed the Middle East. Trans. Jessica Cohen (New York: Metropolitan Books, 2005) p. 286.
} 
began wondering what burden the newly acquired territories would place on the state, given the fact that the Arab world refused to recognize, negotiate or make peace with Israel. $^{3}$ And while both the 1948 and 1967 events were one-sided celebrations for the Jewish world and its friends, they were mourned as both physically and morally devastating episodes by the Arab states and their allies. ${ }^{4}$

By comparison, the Washington-hosted 1993 event - the signing of the first Oslo Accords -- was a moment of globally poignant and highly choreographed peacemaking. It captivated the hearts and minds of most Jews, Arabs, Muslims and governments across the globe. Indeed, the now familiar photograph of a reluctant Israeli Prime Minister Yitzhak Rabin reaching for the hand of an eager Palestine Liberation Organization Chairman Yasser Arafat - a beaming U.S. President Bill Clinton urging them onward could be modern diplomacy's most indelible snapshot. ${ }^{5}$ The initiation alone of the Oslo Accords resulted in a joint 1994 Nobel Peace Prize for its three principal actors -Palestine Liberation Organization (PLO) chairman Arafat, Israeli Foreign Minister Shimon Peres and Israeli Prime Minister Rabin. The reward came simply for the act of

\footnotetext{
${ }^{3}$ On September 1, 1967, leaders of 13 Arab countries gathered in Khartoum, Sudan to pledge to continue a non-military struggle with Israel. The resulting Khartoum Declaration declared there would be "no peace, no negotiations and no recognition" of Israel. As Howard M. Sachar has written, "[It] was the first serious warning to the Israelis that their expectation of an imminent "phone call' from the Arab world [for permanent peace talks] might be a pipe dream." Sachar, p. 676.

Also, the late Rabbi Arthur Hertzberg relates how at the end of June 1967, he was in Israel when he attended a meeting with former Prime Minister David Ben-Gurion. The "father of the State" surprised his audience when he "asserted that if Israel did not now give back, immediately, all the territory that it had captured in recent days - with the exception of East Jerusalem - it would be heading for historic disaster." Arthur Hertzberg, The Fate of Zionism: A Secular Future for Israel \& Palestine. (New York: Harper Collins Publishers, Inc., 2003) pp. ix-xi.

${ }^{4}$ The Palestinians refer to what Israelis call the 1948 War of Independence as An Nakba - or "the great tragedy."

${ }^{5}$ The full text of the first Oslo Accords can be found in Shimon Peres, Battling For Peace (New York: Random House, 1995) pp. 316-327. Peres, then Foreign Minister, signed on behalf of the State of Israel.
} 
signing the document, not for successfully implementing its extremely ambitious plan of setting into motion negotiations for a permanent settlement to conflict.

Other benefits for principal actors were fast in coming as well. First there was a promise of at least $\$ 2.4$ billion in aid for the Palestinians at an October 1, 1993 Washington-hosted international donors conference. ${ }^{6}$ Other results included the improvement of official political and economic relations between Israel and Arab states (particularly Jordan, which on October 26, 1994 signed a peace treaty with Israel), ${ }^{7}$ the acceptance by Israel of the PLO as the legitimate political representative of the Palestinian people (enabling it to shed the global terrorist label gained since its members' series of sensational commercial airliner hijackings and terrorist events of the 1970s) ${ }^{8}$ and the warming within the United States of ties between American Jewish and Arab/Muslim groups.

\footnotetext{
${ }^{6}$ Showing the rapid change of the PLO's standing, only one week after the first Oslo Accords were signed, the United States announced it would jump start the aid process with $\$ 250$ million and called for the donors' conference to take place rapidly. Elaine Sciolino, "U.S. To Contribute \$250 Million In Aid For Palestinians," New York Times. 21 September 1993. For the very negative Israeli perspective on the role of international aid to the Palestinians from 1993-2002, see the detailed report listed as from "Israeli Defense Forces/Military Intelligence," "International Financial Aid to the Palestinian Authority Redirected to Terrorist Elements." 5 June 2002. For an overview of U.S. economic aid during the peace process to the Israelis, Palestinians and the region, see Stuart Eizenstat, "Treasury Deputy Secretary Stuart E. Eizenstat Remark At The Van Leer Forum Jerusalem, Israel," 31 October 1999. U.S. Department of the Treasury. Web. 9 April 2009.

${ }^{7}$ The thrust of the Jordanian peace treaty was spelled out in "The Washington Declaration," signed by Israel, Jordan and the United States on 25 July 2004. See Martin Indyk, Innocent Abroad: An Intimate Account of American Peace Diplomacy In The Middle East. (New York: Simon \& Schuster, 2009) pp. 430433.

${ }^{8}$ Rabin and Arafat exchanged letters on September 9, 1993, in which Arafat wrote in part: "The PLO recognizes the State of Israel to exist in peace and security" and commits itself to "a peaceful resolution of the conflict between the two sides." Rabin tersely recognized the letter in a one paragraph statement that included "Israel has decided to recognize the PLO as the representative of the Palestinian people and commence negotiations with the PLO within the Middle East peace process." Peres, pp. 329-330.
} 
There were, of course, dissident voices from the American Jewish community, which mirrored similar ones in Israel. A loud cry came in particular from the Zionist Organization of America, which around this time began its vocal sharp turn to the right. In fact, on September 20, 1995, the ZOA formally broke ranks with the organized American Jewish community by arguing in front of the U.S. Congress against $\$ 500$ million in American aid to the Palestinian Authority. The acrimony during the testimony became so intense that during a break, Richard Hellman, president of the Christians' Israel Public Action Campaign and a strong pro-Israel advocate, was overheard asking ZOA head Mort Klein and AIPAC head Neal Sher, "Why can't you guys in the Jewish community just get along?"9 Also, giving a hint of the Jewish organizational infighting that would occur throughout the Olso years on the local level as well, the Baltimore chapter of the ZOA would break off and form the independent Baltimore Zionist District (BZD), standing by its notion that Diaspora Jews should not publicly criticize the democratically elected government of the State of Israel. ${ }^{10}$

Such voices aside, in retrospect the celebrated 1993 signing was both the beginning and apex of what became known as the Oslo Process (1993-2000), named for the Norwegian city in which Israeli and Palestinian negotiators - with the mediation of their Scandinavian hosts - secretly crafted their agreement during the previous year. ${ }^{11}$ Israel and the PLO would in turn draft and sign the Interim Agreement on the West Bank

\footnotetext{
${ }^{9}$ Matthew Dorf. "Histrionics Over Peace Process Mark Palestinian Aid Hearing." Jewish Telegraphic Agency. 29 September 1995.

${ }^{10}$ Douglas Feiden. "Baltimore Balks At ZOA Prexy.” Forward. 12 August 1994.

${ }^{11}$ For a personal first person account by a principal participant of how the Oslo Accords came to fruition, see Uri Savir, The Process: 1,100 Days that Changed the Middle East. (New York: Random House, 1998).
} 
and Gaza Strip (often called Oslo II) in Washington, D.C. on September 28, 1995. It was a much more detailed blueprint for Israeli-Palestinian progress, ${ }^{12}$ one widely expected to lead to a Palestinian state and final settlement on what not long before were acknowledged as intractable issues in the more than 100-year-old conflict between Jewish Zionists and the heavily Arab-dominated Middle East.

Yet, after wild swings from progress to despair, the Mideast peace process known simply to those involved with it as "the process" -- collapsed in late September 2000. With that came the advent of the Second or Al-Aksa Intifadah (named for the silver domed mosque on the top of the Temple Mount, a structure revered in the Moslem world). ${ }^{13}$ Suddenly many interested observers were now stunned at not only how remote the prospect of peace between the beleaguered Palestinian and Israeli communities was, but also whether another Arab-Israeli war would break out.

Indeed, ever since that phase of the conflict was ignited in the days following then-Likud opposition leader Ariel Sharon's highly publicized and heavily secured September 28, 2000 walk upon the Temple Mount, ties between Israeli Jews and Palestinians (and by extension the Muslim world) have plunged to a level of deep pessimism and mistrust, not to mention outbursts of serious violence. This has included strings of horrifying Palestinian suicide bombings and shooting rampages throughout

\footnotetext{
${ }^{12}$ The text of the Interim Agreement can be found in Walter Laqueur and Barry Rubin, Eds. The IsraelArab Reader: A Documentary History of the Middle East Conflict. (New York: Penguin Books, 2001) pp. 502-520. Its various sections included stipulations on: elections for the Palestinian Authority, redeployment of Israeli forces, confidence building measures, and even mechanisms for settling disputes.

${ }^{13}$ The sacredness of the Temple Mount to both Jews and Muslims alike is shown in their respective Hebrew and Arabic names - Har HaBayit (Hebrew: Mountain of God's home) and Haram al-Sharif (Arabic: the sacred place). The location is significant in the stories of both the Hebrew patriarch Abraham and the Islamic prophet Mohammed.
} 
Israel, repeated Israeli reprisals (including targeted assassinations of Palestinian terrorists and counter-terrorism raids by Israel Defense Forces regular and undercover units), and three inconclusive minor Arab-Israel wars. ${ }^{14}$ Today, such conflict makes that warm 1993 September day on the White House lawn seem as distant in time as black and white images of Zionist pioneers clearing rock-strewn fields.

\section{I.2 How Oslo Changed American Jewry}

While much has been devoted to the years of the Olso process from a political and military perspective, less attention has focused on its profound effects on American Jewish identity and American Jewish organizations. Yet, events of the period have had a substantial impact in the United States, which in turn has made a mark on U.S. Jewry's lobbying for Israel, which is important to the general American electorate due to American Jewry's disproportionate influence on congressional and presidential elections. (American Jewry's role in U.S. politics will be covered in more detail in Chapter Two.)

Resulting changes for the American Jewish community due to the Oslo process were both external and internal. For the first, American Jewry was involved in a reshaping of old and forging of new coalitions due to Israel's changing challenges. The importance of such relationships to American Jews cannot be minimized. Despite the high visibility in national affairs of both Jewish organizations and individuals, at slightly

\footnotetext{
${ }^{14}$ These "mini-wars" are: the Second Intifadah (September 29, 2000-February 8, 2005). This is an increasingly accepted ending date for this round of the Israeli-Palestinian conflict as it marked the Bush administration-led Sharm el-Sheikh summit, which brought together Israeli and Arab leaders. Others could argue that the Second Intifada ended on August 15, 2008, the date Israel unilaterally set for the start of its withdrawal from the Gaza Strip and a portion of the northern West Bank); the Second Lebanon War (July 12-August 14, 2006); and the Gaza War (December 17, 2008-January 21, 2009). None of these were considered existential wars as were those of 1948, 1967 and 1973. Also, there were no border changes from these latter conflicts, as had been the case with the earlier wars.
} 
less than 2 percent of the overall U.S. population, the organized community needs friends. Noise is one thing, but political allies - the trade of Washington, D.C. and local lobbying efforts -- is another.

These new ties include (for many Jews) the uncomfortable Evangelical-Jewish coalition on pro-Israel advocacy, which unleashed a strong debate within American Jewry over the ultimate cost of such a partnership versus the immediacy of Israel's need for political friends. ${ }^{15}$ A subset here is how some Jews - particularly non-Orthodox ones - watched with rising concern the participation of Christians in major Jewish organizations such as the American Israel Public Affairs Committee, the organized Jewish community’s principal pro-Israel lobbying operation in Washington, D.C. ${ }^{16}$ Meanwhile, new strains arose between Jews and mainstream Protestants regarding Israel. What happened in this era lay the groundwork for major organizational conflict in the immediate post-Oslo years as some mainstream Protestant groups pushed for divestment

\footnotetext{
${ }^{15}$ For one view of the issue, see David Brog, Standing With Israel: Why Christians Support the Jewish State. (Lake Mary, Flor.: Front Line, 2006) pp. 133-157. Brog, who is Jewish, is the executive director of the conservative evangelical group Christians United For Israel, which was founded by the Rev. John Hagee. Brog seeks to persuade American Jews that it is in their and in the State of Israel's interest to embrace the pro-Israel evangelical effort. The internal Jewish debate became even stronger at the outbreak of the Second Intifadah. That's because the political influence of the pro-Israel evangelical community grew during the presidency of George W. Bush, who saw evangelicals as part of his conservative political base.

${ }^{16}$ During the past 20 years, evangelical Christians' participation at local and national pro-Israel events has steadily grown. This is now being manifested again through the 2008 agreement by the Jewish Agency for Israel to bring a member of the International Fellowship of Christians and Jews - an evangelical organization whose head is an Orthodox-ordained American rabbi - onto its board of governors in recognition of the latter's groups tens of millions of dollars donated to Israeli and Russian Jewish immigrant social service projects. Likewise, certain individuals, such as Rabbi Daniel Lapin, an Orthodox rabbi with a conservative political view, often addressed the Christian Coalition's national conventions, such as in Atlanta in 1996.
} 
in pension funds that had dealings with either Israeli corporations or ones that did business with Israel. ${ }^{17}$

Finally, during the Olso process many American Jewish groups established ties with American Muslim counterparts, something reflected on the local level as well. ${ }^{18}$ Not surprisingly, these relationships would be strained anew as the Oslo process imploded and shriller, more uncompromising voices on both sides gained prominence.

As for internal Jewish community shifts, for American Jews the Oslo Process occurred at a precipitous moment in a diverse community whose internal bonds of unity were already fraying on pro-Israel issues. This was clearly seen in the founding and strengthening around this time of both pro-Oslo and anti-Oslo groups that took more ideological stands than the traditional mainstream pro-Israel advocates such as AIPAC, the American Jewish Committee (AJCommittee), the American Jewish Congress (AJCongress), the Anti-Defamation League (ADL) and the National Jewish Community Relations Advisory Council (NJCRAC). This dynamic was evident in the founding of the Israel Policy Forum (IPF, originally known as Project Nishma) and the strengthening of Americans for Peace Now (APN), both of which favored the Oslo Accords. On the other side of the spectrum, this era saw the hard right shift of the Zionist Organization of

\footnotetext{
${ }^{17}$ For an overview of national U.S. church groups and the Arab-Israeli conflict, see Eugene Korn, "Meeting The Challenge: Church Attitudes Toward The Israel-Palestinian Conflict." (New York: Anti-Defamation League, 2002). Since the publication of this document the Israel divestment push of groups, such as the Presbyterian Church, have increased significantly, leading to some divisions within church groups over the policies.

${ }^{18}$ For example, the Baltimore Jewish Council (BJC) has established a dialogue with the regional Muslim community. It includes participation in the BJC's "trialogue," in which Muslims join Christian and Jewish counterparts for a bi-monthly lunch meeting on exploring how the different religions address a topic. BJC members also have an annual kosher dinner at an area mosque and Muslims are invited to various Jewish community events.
} 
America (ZOA) and Americans For A Safe Israel (AFSI), constant and sharp critics of the peace process, the U.S. government's role in promotion of the talks, and the rest of organized Jewry's seeming acceptance of the inevitable success of the negotiations.

There also was an overall recalibration regarding the most effective role for American Jewry's general pro-Israel activities, including the old discussion of how and when American Jews could disagree with the democratically elected government of the State of Israel. ${ }^{19}$

The community even had to take into account the pros and cons of new media such as the World Wide Web, which gave both it and its detractors a chance to quickly spread news and perspectives around the globe that were unfiltered by newspaper or broadcast journalists. In fact, during this period Jewish groups - particularly grassroots ones - sought to shake up growing complacency amongst the rank and file by generating activism with a stream of e-mail alerts, e-letter writing campaigns and the like, basing their information not on news reports, but on what people in Israel were telling them with a stream of e-mail updates. ${ }^{20}$ This provided new challenges to the established American Jewish groups in terms of public posturing on issues such as addressing Palestinian

\footnotetext{
${ }^{19}$ This dynamic is portrayed by Rabbi Arthur Hertzberg, a veteran and outspoken leader of the American Jewish Congress. He writes of how he was reluctant to go public in 1971 when he concluded that he needed to oppose the Israeli government's refusal to give some land to the Egyptians to spur a peace process. "I felt that it was right, and necessary, to argue for my views within Jewish forums, but that I should not go the final step to break with the policies of Israel's government and its supporters in the Jewish world in the public arena." Arthur Hertzberg, A Jew In America. (New York: Harper Collins, 2002) pp. 376-377. Yet, Hertzberg's pen and tongue did not have any such compunction within a decade as he wrote numerous articles and essays criticizing Israel's policies. A vivid example came a decade later in his 1992 book Jewish Polemics (New York: Columbia University Press). The book is a compilation of his essays in national publications. The first section is titled "In Debate With Menachem Begin" and the second "In Debate With Israel."

${ }^{20}$ An example would be the Shomron News Service, which became an important news source for Jewish opponents of the Oslo Accords. It was replaced by the end of the period by Israel National News, both of which are run by Jewish West Bank settlers.
} 
violations of the Oslo Accords or Israeli settlement activities, because now almost instantly, refutations or confirmations of policy statements were available.

Another evident shift in this era was the open schism between the views of nonOrthodox and Orthodox Jews over Israel's course. This would play out in local and national lobbying of elected officials, inner-communal dynamics at national and local Jewish agencies, and even the ways in which Israeli politicians would interact with different segments of American Jewry. Most Orthodox Jews, as with the rest of American Jewry, initially welcomed the Oslo initiatives.

Yet, as the negotiations progressed, Orthodox Jews in general took a more skeptical attitude toward them, as did their organizations. One reason for this is that a greater percentage of U.S. Orthodox Jews than non-Orthodox ones had lived in, visited or knew people living in West Bank settlements. These were venues likely to be evacuated were the Oslo process to come to fruition. ${ }^{21}$

The prospect of such evacuations also clashed head on with theological considerations, which carry great weight in Orthodox circles; official Orthodoxy sees the dicta of various rabbis as binding and responds accordingly. Indeed, some leading

\footnotetext{
${ }^{21}$ While Orthodox Jews are only 10 percent of the American Jewish community, they are a well-organized and vocal segment that in this era formally cemented its Washington, D.C. lobbying presence and activities. Also, nearly 100 percent of Orthodox Jews are involved in Jewish life while only 50 percent of other Jews are engaged on some level with the organized community. Thus, Orthodoxy's strength in the organized community can rise over the 20 percent mark. In a community such as Baltimore, where Orthodoxy is 20 percent of the community according to the 1986 and 1999 demographic studies of the Associated: Jewish Community Federation of Baltimore, Orthodoxy's functional strength can rise to 40 percent of those involved with communal life.
}

For data on Orthodoxy Jewry as a subset of the U.S. Jewish population, see National Jewish Population Survey, 2000-2001. (New York: United Jewish Communities, 2002). For more on Orthodoxy and the Oslo Accords, see Orthodox Union President Mendy Granchow's biography, Journey Through the Minefields: From Vietnam to Washington, An Orthodox Surgeon's Odyssey (Silver Spring, Md.: Eshel Books, 2004) pp. 215-260. 
Orthodox rabbis in both Israel and the United States issued forceful rulings that forbade the relinquishing of the sacred Jewish lands of Judea and Samaria (the West Bank) to non-Jewish entities. ${ }^{22}$ Making this even more emotional was the sense of betrayal felt in Orthodoxy. That's because successive Israeli governments - from those led by the rightof-center Likud Party to those led by the left-of-center Labor Party -- financially invested in the settlements, enabling the purchase of residences in them at much cheaper rates than homes within pre-1967 Israel. ${ }^{23}$ A practical incentive was that some of the settlements were set up specifically for the needs of Orthodox Jews, always having synagogues and mikva'ot (ritual immersion baths), sometimes hesder (army) yeshivot and apartments designed to accommodate the larger families typical in the Orthodox community. Tens of thousands of Jews took advantage of this. While they were not all Orthodox, nearly all were at least traditional in their religious outlook and knew they would be living amongst Orthodox Jews. $^{24}$

At the same time, Orthodoxy in the United States - from centrist Orthodoxy's congregational organization the Orthodox Union to the ultra-Orthodox community's Agudath Israel (whose Israeli counterpart was a party in the Knesset) -- was building its

\footnotetext{
${ }^{22}$ The first major U.S. journal article that triggered the debate in this country - a spillover from the Israeli discussion prompted in 1988 by Rabbi Ovadiah Yosef's contention that Jews could relinquish sacred land to save lives (his pikuach nefesh ruling) - was David J. Bleich's "Withdrawal From Liberated Territories As A Viable Halachic Opinion,” Journal of Halachah and Contemporary Society. 18 (1989): 101-110.

${ }^{23}$ While the settlements began under the Labor governments of the mid-1970s, starting in 1983 their growth was accelerated when the ruling Likud Party and the Gush Emunim settler movement agreed to heavily subsidize new residences in the communities. [Ian Lustick, For The Land And The Lord: Jewish Fundamentalism In Israel. (New York: Council on Foreign Relations, 1988) pp. 156-159.

${ }^{24}$ An early example of how settlements were a powerful religious symbol of Jewish return to the Land of Israel, which naturally resonated within the religious sector, came with the 1977 election of Menachem Begin as Prime Minister of Israel. Soon after the election, he went to the religious settlement of Elon Moreh on the West Bank. There, he grasped a Torah and called for the establishment of "many more Elon Morehs." [Cited in Lustick, p. 40.]
} 
political infrastructure in Washington, D.C. and nationwide. This enabled these operations to emerge stronger and more active than ever in national policy debates both within and outside of the Jewish community. This, too, created a new series of challenges for the principle secular national "Jewish defense agencies" - the AJCommittee, AJCongress and the ADL, not to mention making consensus positions sought by NCJRAC (later renamed the Jewish Council for Public Affairs or JCPA) more difficult to forge. Finally, Orthodoxy's rising political power also created strains with liberal religious groups, such as the Reform movement's Union of American Hebrew Congregations. ${ }^{25}$

\section{I.3 American Jewry's Pre-Oslo Triumphs And Challenges}

Despite such simmering tensions, overall American Jewry had never seemed as viable or successful as it did both to insiders and outside observers in September 1993. This began with the broad social acceptance of Jews in America - too broad, as some sociologists would say, pointing to the disturbingly rising trends of intermarriage and assimilation since the 1970s. Meanwhile, American Jews were integral to the nation's political process and well-known as generous benefactors within and outside of the Jewish community. Finally, and most importantly for this study, when it came to a Jewish

\footnotetext{
${ }^{25}$ The Reform movement is very active in Washington through its Religious Action Center (RAC). The Conservative movement has never had a Washington, D.C., presence, which has made its impact in the nation's capital almost non-existent.

The strains between non-Orthodox and Orthodox groups increased with the advent of the politically conservative administration of President George W. Bush from 2001-2009. It gave Orthodox groups more formal and informal access to top administration planners than in previous years, as reflected in the invitations sent out to White House events such as the annual Chanukah party.
} 
activist agenda, two of the three of the community's widely agreed upon collective tasks since the end of World War II could be deemed undeniable successes.

The first was the political fight to free Soviet Jews (now Russian/Eastern European Jews), which energized Jewish college students in particular. By the start of the 1990s, with the fall of the Soviet Union and the end of the Cold War, ostensibly any Jew who wanted to leave the Former Soviet Union (FSU) could now do so. ${ }^{26}$

Second was the formalization and recognition of Holocaust commemoration throughout the country, including ceremonies and programs funded by national, state, and local governments, and in public and private schools. There also was the construction or expansion of dozens of local Jewish community Holocaust museums. Nationally, the most visible event was the April 22, 1993 dedication ceremony for the U.S. Holocaust Memorial Museum in Washington, D.C., which was attended by President Bill Clinton, Vice President $\mathrm{Al}$ Gore and numerous other national and international dignitaries. The structure's physical presence alone on the National Mall assured a constant flow of visitors and visibility. ${ }^{27}$

However, the third great pillar that had once had broad support among U.S. Jews - staunch support for the democratically elected government of Israel, nearly regardless of its actions -- was already under attack in the immediate pre-Oslo years. In fact, the Oslo Process only made these strains more evident, and certainly deeper, when it came to

\footnotetext{
${ }^{26}$ For the perspective of U.S. Jewish activists on this campaign, see: Philip Spiegel. Triumph Over Tyranny: The Heroic Campaign that saved 2,000,000 Soviet Jews. (New York: Devora Publishing, 2008) 227-240 and Shoshana Cardin. "Marching for Soviet Jewry," in Shoshana: Memoirs of Shoshana Shubin Cardin. (Baltimore: Jewish Museum of Maryland, 2008) pp. 111-126.

27 According to the Museum's promotional material in early 2009, by 2008 it had seen 30 million visitors, including eight million school children, pass through its doors. The Museum estimates that 90 percent of those guests are not Jewish.
} 
presenting a united Jewish front on the State of Israel's policies to America's public and to its elected representatives. This trend toward discord was reflected in the actions of national Jewish organizations, rabbis from different Jewish theological streams, and highprofile individual Jews offering widely discussed criticism. ${ }^{28}$ Most of this dissension focused on how to respond to the increase in the West Bank/Gaza Strip Jewish settlement building of the Begin-Shamir governments from 1977-1992 on lands that the Palestinians wanted for their own state, as well as Israel's strong physical response to the First Intifadah, which began in December $1987 .{ }^{29}$ In addition to the internal American Jewish splits, there also were clashes that openly pitted portions of organized American Jewry against the State of Israel's government itself. Indeed, by 1993 three particular splits among American Jewry regarding Israeli policies had already erupted in loud verbal battles:

1) The noshrim ("drop outs") debate of the 1970s and 1980s over whether emigrating Soviet Jews were obligated to resettle in Israel instead of moving to the United States;

2) the 1988 "Who Is A Jew?" controversy, which exposed the difference in conception and concerns of Israeli and American Jews regarding Jewish identity;

3) Israel's 1991 request for a U.S. guarantee for $\$ 10$ billion in bank loans to build the Jewish state's infrastructure as it absorbed hundreds of thousands of Soviet Jews.

\footnotetext{
${ }^{28}$ One example of high profile criticism from a Jewish individual came in the penning of a 28 January 1988 opinion piece for the New York Times by Woody Allen, a self-proclaimed non-activist, but nationally renowned actor/director. "As a supporter of Israel," he wrote, "and as one who has always been outraged by the horrors inflicted on this little nation by hostile neighbors ... I am appalled beyond measure by the treatment of the rioting Palestinians by the Jews." The op-ed released a storm of discussion and reaction amongst letters to the editor writers and was a topic of conversation for Jewish activists.

${ }^{29}$ Shimon Peres was Israel's Prime Minister from 1984-1986 during a national unity government between his Labor Party and Shamir's Likud Bloc. Yet, even then settlement building continued, albeit with less fanfare. In a rotation agreement, Shamir served as Prime Minister from 1986-88 and Peres became his Foreign Minister.
} 
In the noshrim debate, since the Soviet Jews had gained exit visas for the Jewish state, Israelis insisted they emigrate there. However, many of those fleeing their native land's anti-Semitism and economic stagnation preferred North America, whether for economic reasons or family reunification. American Jews, deeply steeped in both the principal of freedom of immigration and the desire to welcome Jews in distress (something many felt they did not fight hard enough for during the Holocaust era), openly welcomed the Soviet immigrants with financial, vocational and other forms of assistance. American Jewish federations, in fact, made the need to fund resettlement in America a major part of their annual campaign for both money and volunteers. In 1990, they ran an emergency Operation Exodus fundraising campaign, which called for contributions in addition to those sought for the annual campaign. (A portion of the latter's proceeds were already going to help Soviet Jews through funding the activities of the American Jewish Joint Distribution Committee and the Jewish Agency for Israel.)

The Israelis complained bitterly that American Jews were inducing Soviet Jews to bypass the Jewish state, which was materially less comfortable and militarily more threatened than life in, for example, Baltimore, Chicago or Los Angeles. That, the Israelis added, hurt them deeply in three ways: in the hopes for Diaspora solidarity; in the push for demographic strength in relation to the Israeli Arab minority (20 percent of Israel's population) and in relation to the overwhelming demographic majority of surrounding Arab states; and in the battle to attract technically trained immigrants. Soviet Jews were 
well known for their scientific and academic skills , not to mention their being highly regarded for participation in and appreciation for all forms of the arts. ${ }^{30}$

Another reason for this reluctance on behalf of American Jewry to force Soviet Jews to head toward Zion could have been psychological. If they themselves were not moving to Israel, how could they force others to do so? But it is more likely that the vast majority of American Jews, themselves descendants of Russian Jews who had arrived within the last century, felt a special bond to these Jewish immigrants that they did not feel for Jews from Arab lands. In fact, this gave present-day American Jews a sense of closeness to the Soviet Jews whom they saw figuratively as (and sometimes literally were) long-lost relatives whom they personally wanted to assist, a role that for a multitude of reasons - particularly minimal political power and wealth -- the community could not fill during the horrible years of the 1930s and early 1940s.

When it came to the second clash, the "Who Is A Jew?" battle - not a new fight and one that would reappear in 1997 for another round ${ }^{31}$ - in 1988 both Likud's Yitzhak

\footnotetext{
${ }^{30}$ For more on the tensions created and suggestions on dealing with this, see Fabian Kolker, "A New Soviet Jewry Plan," in Soviet Jewry in the Decisive Decade 1971-80. Ed. Robert O. Freedman (Durham, N.C.: Duke University Press, 1984) pp. 79-98. Kolker's plan was not adopted.

${ }^{31}$ The "Who Is A Jew" battle stems from the 1950 Law of Return, which states "every Jew has a right to come to this country as an oleh [immigrant]." However, the definition of "Jew" remains highly debated in the Jewish world. As such, it has been the subject of numerous debates between Israel's Orthodox and nonOrthodox communities (the former including Israel's small Reform and Conservative Jewish communities). The battles have become known as the "Who is a Jew?" controversy, which now primarily deals with who is allowed to perform conversions in Israel and the validity in Israeli secular law of conversions performed by non-Orthodox rabbis outside of Israel.

The law had a major challenge in 1970 when an Israeli-born Jewish naval officer, married to a non-Jew, sought to have his children registered as "Jewish." An amendment passed on March 10, 1970 did little to clarify this when it declared "For the purposes of this Law, 'Jew' means a person who was born of a Jewish mother or has become converted to Judaism and who is not a member of another religion." Thus, the definition of a "Jew" remains controversial because who could perform a conversion was not spelled out. As a result, the issue periodically became the subject of Israeli national debates, political demands of religious and secular parties, and various court cases. It remains contested as of this writing.
} 
Shamir and Labor's Shimon Peres toyed with amending the Law of Return. It declared that any Jew was automatically entitled to Israeli citizenship. The confusion came from the word "Jew," which is defined as anybody born of a Jewish mother, or converted to Judaism. What constitutes a valid conversion, however, has been a periodic source of controversy throughout the State of Israel's history. In the wooing of Orthodox parties for their potential new governing coalitions, both Shamir and Peres considered the Orthodox parties' request to formally introduce a definition of a Jew that stipulated either being born to a Jewish woman or converted by an Orthodox rabbi. Until this point, there was an informal understanding that anyone converted by any rabbi outside of the Land of Israel (including non-Orthodox ones) was to be accepted as Jewish by Israel's Ministry of Absorption. When Shamir and Peres began openly discussing shifting this, an outraged leadership of American Jewish life - some of whom had children married to non-Jews or were active in the Reform movement, which since 1983 had accepted patrilineal descent to determine if a child were Jewish -- continually made their concern and even anger on this issue felt to Israeli representatives in the United States and Israel. ${ }^{32}$

Finally, there was the loan guarantees issue, which needs to be understood in the context of the Shamir government's unrelenting support for Jewish West Bank settlement. This issue created strains not only within the American Jewish community,

For detailed background on the "Who is a Jew?" issue, see S. Clement Leslie, The Rift in Israel: Religious Authority and Secular Democracy (London: Routledge \& Kegan Paul, 1971), pp.35-47, and Norman L. Zucker, "The Coming Crisis in Israel: Private Faith and Public Policy (Cambridge, Mass.: The MIT Press, 1973), pp. 172-207.

${ }^{32}$ Shoshana S. Cardin relates how as chair of the Conference of Presidents of Major American Jewish organizations in 1987, she flew to Israel to tell Prime Minister Yitzhak Shamir that changing the law would outrage American Jews. When he responded, "American Jews will learn to live with it," she said she even surprised herself with her vehement response of, "Mr. Prime Minister, not this time!" Cardin, pp. 93-94. 
but became a national issue in the United States from 1991-1992. In short, in 1991 Israel signaled it would soon request an American guarantee for $\$ 10$ billion in loan guarantees not outright loans or grants, something that would have cost the U.S. taxpayers money to pay for infrastructure building to help absorb the continuing flow of Soviet Jews to the State of Israel.

President George H.W. Bush and Secretary of State James Baker III asked the Jewish state to agree to a 120-day delay. That, they said, would enable them to successfully launch the U.S.-driven and Madrid-hosted Israeli-Arab peace conference. Organized American Jewry - with the exception of a handful of liberal groups - fought with the administration publicly to not place what they considered a matter of humanitarian response on a political playing field. They also argued that Israel had honored Washington's request to sit out the 1991 Gulf War, even as dozens of Iraq SCUD missiles fell on the Jewish state and Israel did not respond militarily. This, American Jewish leaders argued, was a huge sacrifice which should be rewarded by signing the loan guarantees. Privately, however, some U.S. Jewish leaders virtually begged Shamir to not pursue the loan guarantees at this time. ${ }^{33}$ Much of the tension involved came from the Bush administration's linkage of the guarantees to an agreement by Shamir to stop building settlements, to which the Israelis would not consent.

Meanwhile, disturbing trends in American Jewish life were compounding an increasing sense of distance from the State of Israel. In fact, by 2000 the sociologist

\footnotetext{
${ }^{33}$ Shoshana Cardin writes about how in speaking to Prime Minister Shamir, "I urged him to delay the loan guarantees request at least until after the start of the pending Madrid Peace Conference. Our meeting was cordial, but the prime minister was famously stubborn and I didn't convince him to hold off." [Cardin, pp. 134-135.]
} 
Steven M. Cohen had found that for every 10-year age period, there was a 5 percent drop in support for Israel. ${ }^{34}$ Further confirmation of this trend came when a 1998 poll by the Los Angeles Times, published on the occasion of Israel's $50^{\text {th }}$ anniversary, found that the 58 percent of American Jews who felt close to Israel marked a 10 percent drop from a decade earlier; the decline was even greater when young adults alone were taken into consideration. ${ }^{35}$ Thus, while the leadership was wrapped up in important debates regarding how they would respond to policies from Jerusalem, fewer younger Jews seemed interested in the complicated challenges facing the Jewish State than were those of past generations, the latter often people who personally had experienced or in some way participated in advocating for Israel during its moments of existential crisis.

Ironically, the organized Jewish community unwittingly enhanced this trend of distancing from Israel with its general turn inward during this era, meaning away from the internationalist orientation that had so marked its activism of recent decades. This turn was primarily because the leadership was increasingly focused on countering alarming reports of how a majority of young Jews getting married were wedding Gentiles and not making Jewish choices when it came to raising their children. ${ }^{36}$

\footnotetext{
${ }^{34}$ Steve T. Rosenthal. Irreconcilable Differences: The Waning Of the American Jewish Love Affair With Israel. (University Press of New England for Brandeis University Press: Hanover, N.H. 2001), p. 171.

${ }^{35}$ Ibid, p. 171.

${ }^{36}$ A high profile example of this came with the July 19, 1986 wedding of Caroline Kennedy (daughter of the late President John F. Kennedy) to Edwin Schlossberg (the grandson of Ukrainian Jews and a noted designer, author and artist) at Our Lady of Victoria Church in Centreville, Massachusetts.
}

The 1990 National Jewish Population Study said that among recent marriages, 52 percent of Jews were marrying non-Jews. While that number was debated by columnists and demographers, it stood out for many as the most glaring statistic from the study and was often cited in speeches and meetings. 
This spurred funding of what became known as the "continuity agenda," a series of efforts designed to bolster American Jewish identity and affiliation at home. While a pro-Israel stance was a pro-forma part of the agenda, there was increasing focus on both the cultural zeitgeist of spirituality and serious adult education as a means to bolster allegiance to the Jewish community. This could be seen in the growth of the Florence Melton Adult Mini-School and CLAL-The National Jewish Center for Learning and Leadership. CLAL ran text study workshops at the General Assembly of the Council of Jewish Federations (a.k.a. the G.A.). That gathering, the largest and most important annual national Jewish conference, was once a bastion for a primarily secular Jewish leadership focused on political issues and social issues, as well as discussing policies on how to advocate for Jews in need at home and abroad. In the 1990s, it regularly featured both volunteer and professional leaders speaking in religious terms about American Jewry’s promise and responsibilities.

\section{I.4 Oslo's Opportunities And Crises}

The signing of the Oslo Accords themselves unwittingly provided another pretext for American Jewish leaders to further focus on their domestic Jewish community's immediate needs. After all, top Israeli leaders were urging just such a response, albeit not always in the most diplomatic of fashions. In fact, top Israeli leaders such as Yitzhak Rabin, Yossi Beilin and Avraham Shochet joined in clouding the sense of a defined role for American Jewry in Israel's unfolding new future with their dual message, words often delivered in undiplomatic tones more at home in the rancor of Israeli political dialogue than in the general politeness of American society. The first half of the Israeli 
communication was that to save Jews abroad, American Jews were foremost obligated to build their own Jewish identity, which intermarriage showed was slipping. The second was a "thanks but no thanks" declaration. That is, Israel - a First World country that could handle itself financially, politically and militarily -- no longer needed the charity or even political activism of American Jews, which for many American Jewish leaders had become their most visible expression of being Jewish. ${ }^{37}$ Such blunt language infuriated much of American Jewish leadership, many of whom were second and third generation activists in the effort of advocating for the creation of and then the well-being of the Jewish state.

As a result, and due to the previously mentioned continuity agenda, some of those shaping the American Jewish agenda were understandably no longer riveted to the increasingly complex nuances of Israel's daily being, whether regarding the peace process, or the state's intensifying cultural, religious and social internal strains.

None of this is to suggest that American Jewish leadership and their followers had simply walked away from the State of Israel's fate. Rather, it is to say that the agenda became more crowded and complicated. That naturally left less time to deal with the difficult matters emanating from Jerusalem. For sure, American Jewry had plenty to grapple with from 1993 to 2000 when it came to its pro-Israel docket. For the still attuned, the drama never seemed to stop. After the historic paradigm shift of the Olso signing, there was the struggle to implement what it called for as well as monitoring the

\footnotetext{
${ }^{37}$ As but one example, Yossi Beilin, who served as Rabin's Deputy Foreign Minister, continually made headlines on the topic. For example, he writes "Israel Bonds is classic of an organization that no longer has a role to play but still continues to function due to organizational inertia... The case of the Jewish National (JNF) fund is even more pathetic and severe." Yossi Beilin, Israel and Diaspora Jewry in the Twenty-first Century. (New York: Schocken, 2000) pp. 102-104.
} 
U.S. role in that effort, which introduced the recently unthinkable notion of having U.S. Jewish groups advocate for aid to the Palestinians.

Then came the devastating emotional impact of the Rabin assassination on November 4, 1995. That was followed by the surprise victory of Binyamin "Bibi" Netanyahu in the May 29, 1996 Israeli elections, which demanded a new need to navigate the sharp shifts in Israeli administrations from the "land for peace" oriented Rabin-Peres team to the Netanyahu team, which insisted on "reciprocity" from the Palestinians as a price for advancing the negotiations. Reciprocity was defined as an absolute clamp down on Palestinian terror by Palestinian Authority head Yasser Arafat. Further, while acknowledging the binding nature of the Oslo Accords - which Netanyahu had voted against in the Knesset -- on his government, the new prime minister made it clear that he was far from happy about the negotiations of the preceding two-and-one-half years. As such, he was in no rush to bring them to fruition along their existing path and pace. That brought rising tensions with the Clinton administration, which likewise put American Jewry on the defensive. After that came Labor Party leader Ehud Barak's victory in the 1999 Israeli elections, which brought immediate relief to pro-Oslo advocates. Yet, Barak's seemingly hasty and often secretive negotiating style would soon frustrate both the White House and the American Jewish leadership.

American Jews also began finding themselves part of the peace process. President Clinton and his top policymakers understood the important role U.S. Jews could play in creating success for the Mideast peace talks. This would come either through: contact with members of Congress who often looked to the local Jewish community for support; passing messages to or on behalf of Israeli leaders, with whom some American Jews had 
close personal friendships ${ }^{38}$; or pushing their own rank and file to lobby fellow citizens for the necessary U.S. political and financial support integral to the Oslo process's eventual completion. Indeed, some of these U.S. policymakers specifically note in their post-Oslo books and speeches the need to have good ties with and understand the innerworkings of American Jewry if an administration is to successfully persuade the Congress and public of the need for an activist U.S. role in the peace process. ${ }^{39}$

As Aaron David Miller, a former top U.S. State Department diplomat on the Israeli-Palestinian conflict wrote retrospectively in 2008, in part as a warning to future administrations, "No ethnic group, however, has the power and focus of the American Jewish community... it is the survival of Israel for which the Jewish community has consistently and tirelessly fought, organized and rewarded or punished politicians."

Yet when the Second Intifadah erupted in late September 2000, much of American Jewry's leadership seemed to easily drop its peace process enthusiasm and readily jump back to the familiar landscape of defending Israel's cause to the mass

\footnotetext{
${ }^{38}$ One example came with the tie between American Jewish philanthropist and Jewish National Fund leader Ron Lauder and Binyamin Netanyahu. The Israeli prime minister asked Lauder to secretly pass messages from him to Syrian President Hafez Assad. When Barak came to power, at Netanyahu's request, Lauder briefed a surprised President Clinton and Barak on those talks. Martin Indyk, Innocent Abroad: An Intimate Account of American Diplomacy in the Middle East. (New York: Simon \& Schuster, 2009), pp. 246-247.

${ }^{39}$ Vice President Al Gore made these sentiments clear during his May 23, 1999 speech to the AIPAC Policy Conference. He said in part, “....my sense of America's national security needs put me in alliance with all of you. Our shared commitment to a strong America and a strong Israel, to religious liberties and civil rights, to a progressive immigration policy and a humane social safety net -- all these caused my acquaintance with the American Jewish community to grow into a strong relationship that has now flowered into deep friendship."

${ }^{40}$ Aaron David Miller, The Much Too Promised Land; America's Elusive Search for Arab-Israeli Peace. (New York: Bantam, 2008) p. 88. Miller was the longest-serving high profile State Department negotiator working on the Arab-Israeli conflict. He served from the administration of George H.W. Bush (1989-1993) through that of Bill Clinton (1993-2001) and into the first two years of the administration of George W. Bush (2001-2003).
} 
media, the general public and the nation's leaders. A problem, however, was that many American Jews had moved on either from the organized community or from pro-Israel activism. One must reiterate this does mean that Israel was not important to most American Jews in a broad sense. It does mean that many of them were less interested than were previous generations in Israel's daily workings and the challenges of putting defense of the Jewish at the top of their concerns. For the younger Jews, Israel's story was a complicated one (and thus more difficult to relate to) and less pressing than Jewish concerns at home seemed to be - if they were even focused on Jewish concerns. Some younger Jews in particular often seemed more captivated by the very personal "spiritual" experiences being offered by the rise in popularity of the Jewish Renewal movement, private chavurot (small fellowship groups, which even some larger synagogues began offering in the hopes of creating a sense of intimacy in large congregations that could have more than 1,000 family units), and modern, if superficial, practices of the once nearcloseted study of Kaballah (Jewish mysticism) - something given particular attention by the celebrity world's fascination and participation with the Los Angeles-based Kabbalah Center. $^{41}$

\footnotetext{
${ }^{41}$ For more on the Jewish Renewal movement's rise in American Jewish life, see Rodger Kamenetz. "The Jewish Renewal Movement: From the Counter-Culture to the Mainstream." Moment, December 1994. pp. 42-49. Kamenetz has written several books that are important in the Jewish Renewal movement. The most popular, which details his being part of a delegation of American Jews that met with the Dalai Lama, is The Jew in the Lotus. (San Francisco: HarperOne, 1994).
}

For more on how Kabbalah plays among American celebrities and the Hollywood culture in general, see Yossi Klein HaLevi's article "Like A Prayer: Hollywood Goes Kabbalah" in The New Republic, 10 May 2004. pp. 18-21. Klein HaLevi, a modern Orthodox Jew raised in the United States and living in Israel, tries in vain to understand the spiritual grip of the Kabbalah Center and its leader, Rav Moshe Berg, on his followers. 
Complicating matters even more for pro-Israel activists as new violence spread, during the 1990s membership in Jewish organizations continued its slow decline of recent decades. That was clearly weakening the long-term fundraising capability and influence of once large membership-based groups. ${ }^{42}$ It is important to note that none of this happened in the Jewish world in a vacuum. In fact, there had been - and continues to be at this writing -- a general drive toward individualism in American society, a move away from the sense of collective purpose often provided by belonging to a range of social, religious and activist groups. Even in organizations that maintained their membership, volunteers were playing less of a role. As author Robert D. Putnam wrote in his acclaimed 2000 book Bowling Alone, between 1973 and 1994 the number of people involved in membership roles in "anything from an 'old-fashioned' fraternal organization to new age encounter groups" dropped by 50 percent. $^{43}$

This all laid the groundwork for a community whose leadership by 2000 was both struggling to advocate on behalf of Israel and to keep its broader membership involved and educated on the conflict (and basically Jewish life in general, at least as it was represented by American Jewry's major organizations). With that as a backdrop, this

\footnotetext{
${ }^{42}$ For a broad view on what this means to the organized American Jewish community, see James D. Besser. "In Deep Water: The World Is Award With Jewish Organizations Approaching Oblivion. Baltimore Jewish Times. 28 February 1992, pp. 50-55. Besser was widely considered a top reporter/commentator on the actions of American Jewish organizations in the 1990s, a period in which he served as the Washington correspondent for the Baltimore Jewish Times an the New York Jewish Week. His weekly analysis column was written for the Baltimore paper but often reprinted in numerous other Jewish newspapers around the United States.

${ }^{43}$ Robert D. Putnam, Bowling: Alone: The Collapse and Revival of the American Community. (New York: Simon \& Schuster, 2000) p. 60. The emphasis is Putnam's. The nexus of Putnam's book is that the dramatic decline of the social networks once provided by American bowling leagues was emblematic of the decline of American culture's sense of collectiveness. Thus, individualism - which worked in the opposite direction of strengthening organizations - had risen in prominence. This meta-principle was reflected in trends in the American Jewish community and its organizations.
} 
paper will analyze the dynamics of U.S. Jewry's identity shifts during the Oslo years regarding the community's once much more cohesive pro-Israel activism. This will be done by exploring how U.S. Jewry was a factor in and reacted to the policies of the U.S. government, the Israeli government's interaction with U.S. Jewry, and U.S. Jewry's increasing internal conflicts when it came to pro-Israel advocacy.

\section{I.5 Rationale For This Research Project}

While there have been essays exploring various aspects of how the Olso process made an impact on American Jewry, a comprehensive analysis reflecting upon, putting into broader context and weaving together the totality of what happened has yet to appear. To date, much of what is available has focused on one particular dimension, such as Steven T. Rosenthal's analysis of the shifting U.S. Jewish emotional allegiance to Israel in his 2001 book Irreconcilable Differences: The Waning of the American Jewish Love Affair With Israel. ${ }^{44}$ However, using this as an example, his work does not cover American Jewry's importance in the political sphere, religious shifts, communal dynamics and the impact that actions of Israeli leaders had on American Jewish attitudes. Rather, it is primarily reliant on opinion polls and organizational statements.

In addition, many articles and analyses have been snapshots of the moment in response to a trigger incident - such as the Rabin assassination or Binyamin "Bibi" Netanyahu's handling of the "conversion crisis" of 1997-1998. Some others are tinged

\footnotetext{
${ }^{44}$ Steven T. Rosenthal. Irreconcilable Differences: The Waning of the American Jewish Love Affair With Israel. (Hanover, N.H.: Brandeis University Press, 2001). Rosenthal explores how American Jews via organizations and as individuals related to the State of Israel from its inception to 2000. I consider his work strictly an "internal Jewish dialogue." Indeed, it is part of the Brandeis Series in American Jewish History, Culture, and Life.
} 
with the perspective of writers trying to prove a point. A particular example of the latter would be the series of essays in Commentary magazine in 1993 and 1994 by Norman Podhoretz, in which he expressed strong skepticism regarding the possibility of success in the peace process. ${ }^{45}$ As Podhoretz wrote in the June 1993 issue of the publication, he had yet to find an explanation by a Rabin government official that refutes his:

"...contention that a new Palestinian state is far less likely to bring harmony and peace than it is to trigger instability and then another war. Such a war, I maintained, fought against a weakened Israel, would give Arab countries (including the "sane" ones) one more chance to realize their dream - a dream they have not yet abandoned - of wiping the Jewish state off the map. ${ }^{46}$

With that in mind, this study will explore diverse sources including: Jewish and national newspaper reporting (reflecting internal communal debates and their impact on the community's public positions; biographical reflections of American Jewish and U.S. governmental leaders of the era; U.S. Jewish attitudinal studies and surveys; the speeches and actions of the very diverse Israeli leaders of the era; evaluations of U.S. Jewry's importance in the national electorate, and the personal relationships between key U.S. and Israeli leaders. It will also explore the Clinton administration's understanding of U.S. Jewry's role in Mideast peace making, and the impact of shifts in U.S. Christian perspectives on the State of Israel, particularly between mainstream Protestants and Evangelicals.

Such a more comprehensive undertaking is possible now, more than 16 years after the Oslo Process began, because perspective has been gained and new information has

\footnotetext{
${ }^{45}$ Those essays are: "On the Peace Process." Commentary. April 95.4 (1993): 12-23, "Another Statement on the Peace Process. Commentary. June 95.6 (1993): 25-30, and "The Peace Process So Far."

Commentary. February 96.2 (1994): 21-25.

${ }^{46}$ Podhoretz, “Another Statement on the Peace Process.” Commentary. June 95.6 (1993), p. 30.
} 
come to light. This is due in part to the post-Oslo publication of various memoirs and autobiographies of principal U.S. volunteer Jewish leaders and U.S. government actors of the era.

In addition, many top U.S. Jewish professionals from the 1993-2000 period either remain in their positions or have taken new ones within the Jewish communal world. Thus, they are either again or still interacting with familiar U.S. officials, drawing from and commenting upon past experiences along the way. ${ }^{47}$

Following this introductory chapter, Chapter Two will survey the importance of American Jewry in the U.S. political landscape and the weight of its views regarding Israel in that realm. It will review U.S. policy toward Israel on the eve of the Oslo era and American Jewish activity regarding those issues, focusing in particularly on the contentious final year of the presidential administration George H. W. Bush and the less than harmonious start of Yitzhak Rabin's tenure as Israeli Prime Minister (1992-1995) regarding his relationship with American Jews. In doing so, I will briefly review U.S. policy toward Israel until 1993, including the recognition of the difficulty of Middle East peace making as exhibited by the 1991 beginning of the Madrid Process.

This chapter will include an attitudinal profile of American Jewry and its major public advocacy activities on the eve of the Oslo era. The focus will be on the shifts in

\footnotetext{
${ }^{47}$ These individuals, all of whose organizations have a seat at the umbrella group the Conference of Presidents of Major American Jewish Organizations (popularly known as "the President's Conference"), include: Abraham Foxman of the ADL; David Harris of the AJCommittee; Morton Klein of the ZOA; Dan Mariaschin of B'nai B'rith International; Rabbi Eric Yoffie of the Union of Reform Judaism (URJ formerly the Union of American Hebrew Congregations); Rabbi David Saperstein, head of the URJ's Religious Action Center (RAC) in Washington, D.C.; and Nathan Diament, the Washington representative of the Orthodox Union. Also, Howard Kohr has headed AIPAC since 1996 and Rabbi Steve Gutow, now head of the Jewish Council for Public Affairs, was the founding director of the National Jewish Democratic Council (1990-1996).
} 
relating to the three traditional pillars of modern American Jewish identity - the struggle to free Soviet Jewry, the institutionalizing of Holocaust memorialization in general society, and the campaign for pro-Israel advocacy in Washington and among the general public. Finally, it will show how the "continuity agenda" began rising to the top of American Jewish concerns, inevitably competing with pro-Israel activism.

Chapter Three will explore how the U.S. government initially responded to the Oslo Accords and then the negotiating process itself. It will pay close attention to the role American Jews played in both expressing their views to the Israeli government and taking the administration's case to Capitol Hill - which from 1995 to 2000 was dominated by the Republican Party and not President Bill Clinton's Democratic Party. I will note how initially this task was made more difficult by Yitzhak Rabin himself as he chastised American Jewry in the months prior to and immediately following the Oslo Accord signing with his criticizing and minimizing of their pro-Israel activities.

This chapter will then look at how the American Jewish leadership - following the line from the Rabin administration - was so persuaded that peace was coming to the Arab-Israeli conflict that they began thinking about their agenda after that seemingly inevitable occurrence. Finally, this chapter will review the devastating impact the Rabin assassination had on American Jewry, the short-lived attempts at putting forward a face of Jewish unity, and how both American Jewry and the White House tried to energize the peace process in the short-lived Peres administration that unsuccessfully sought to carry forth the Rabin-sanctioned Oslo Accords.

Chapter Four will deal with the very different Israeli government of right-ofcenter Likud leader Binyamin Netanyahu (1996-1999). It will comment upon the tensions 
that his policies created between the Government of Israel and both the Clinton administration and much of American Jewry. Still, during this period, Netanyahu surprised some policymakers by giving up 80 percent of the West Bank city of Hebron to the Palestinians as well as pledging to move forward on an additional 13 percent withdrawal of the West Bank. Such a move, it was said at the time, ended the right's dream of "Greater Israel." This chapter also will look at the heated internal strains the Netanyahu government brought to Jews regarding the "conversion crisis" of 1997-98, which was a product of Netanyahu's seeking to appease Orthodox coalition partners whose vote of "no confidence" could end his tenure as Israel's leader by removing his majority of support in the Knesset.

Chapter Five will deal with the next shift in Israeli political life with the mid-1999 election of Ehud Barak. While it came in with much fanfare regarding White House response, and that of much of American Jewry, it ended in a loss of hope brought on by the failures of Barak's administration regarding the peace process and the outbreak of renewed, sustained violence. First came a failed summit with Syrian leaders in Shephardstown, West Virginia. And then the highly anticipated - and as it turned out vastly premature - Camp David II summit with President Clinton and Yasser Arafat in the summer of 2000. Within months, American Jewry and the White House were scrambling to respond to spiraling violence in what would become the Second (or AlAksa) Intifadah. As a result, American Jewish leadership returned to its "crisis mode" of responding to events in Israel. The problem, however, was that many Jews, particularly younger ones, had moved on to other concerns and felt less of an allegiance to the Jewish state than successive preceding generations since 1948. 
This period also will deal with the post-Camp David II scramble for negotiations first through President Clinton's "bridging proposals" of December 2000 and then the last-gasp negotiations held at the Taba resort in Egypt, just over the Negev Desert border with Israel.

Chapter Six, the final chapter, will draw conclusions from the research presented. In particular, it will trace lessons learned for both the American Jewish community and Israeli leadership as well as synthesize the material already covered.

\section{$\underline{\text { 1.6 Research Materials and Sources }}$}

This research will be accomplished by drawing on the increasingly diverse sources available. In addition to numerous works of academics both during and after the Oslo years, I will analyze the major works of the period about the political, sociological, and religious state of American Jewry and how that impacts its relationship to Israel. This will be done by looking at speeches by the leaders of American and Israeli communities of the period, including: at the annual General Assembly of the umbrella Jewish federation group the Council of Jewish Federations (from 1999-2009 the United Jewish Communities and since November 2009 the Jewish Federations of North America), at the annual AIPAC policy conference, at the annual plenum of the NJCRAC (now JCPA), at conventions of the Anti-Defamation League (ADL), and in addresses to other Diaspora Jewish groups (whose leadership is primarily comprised of American Jews). I also will examine the relevant major speeches of top U.S. policy makers of the era, such as President Bill Clinton, Vice President Al Gore, and Secretaries of State Warren Christopher and Madeleine Albright to Jewish and general audiences. 
I will draw on the numerous autobiographies, speeches and comments of principal players who dealt with U.S. policy toward Israel of the era. This will include: works by U.S. Presidents George H. W. Bush (1989-93) and Bill Clinton (1993-2001), U.S. Secretaries of State James Baker, Warren Christopher and Madeleine Albright; CIA Director George Tenet (1996-2004); U.S. Jewish volunteer leaders such as Conference of Presidents of Major American Jewish Organizations (Presidents Conference) Chair Shoshana S. Cardin, Orthodox Union (OU) President Mendell Granchow and long-time American Jewish Congress (AJCongress) leader Rabbi Arthur Hertzberg; U.S. Jewish professional leaders such as Abraham Foxman of the ADL, David Harris of the AJCommittee, and Rabbi Eric Yoffie of the URJ. Likewise, I will look at remarks by Israeli Prime Ministers Yitzhak Shamir (1983-84; 1986-92), Yitzhak Rabin (1993-95), Shimon Peres (1996-96), Binyamin Netanyahu (1996-99), and Ehud Barak (1999-2001) to and about American Jews.

Also analyzed will be press releases, statements, and initiatives of major U.S. Jewish groups. Numerous Jewish population studies and surveys will be explored, including the 1990 National Jewish Population Study (NJPS), the 2000-2001 NJPS, and in particular the annual population surveys of the AJCommittee. In addition, important texts to be analyzed are the resolutions passed by groups, particularly the NJCRAC/JCPA. These documents often have policy recommendations. Further, since these organizations are consensus-seeking groups, they reflect a broad popular opinion from member organizations with diverse opinions on specific issues. ${ }^{48}$ Thus, these

\footnotetext{
${ }^{48} \mathrm{JCPA}$ is comprised of representatives from 14 national Jewish bodies and 125 local Jewish community
} relations councils (CRCs), one of the latter of which is an agency or desk at nearly every Jewish federation 
resolutions can come closer than anything else at that moment regarding the often elusive common ground sought among American Jewry's diverse organizations regarding the state of Israel and other matters.

Other sources include books and studies by principal members of the U.S. negotiating team, which in part reflect on American Jewry's role in the process. This will include post-Oslo texts by Dennis Ross, Aaron Miller, Dan Kurtzer, Martin Indyk (all of whom happen to be Jewish). In addition, I will look at the Clinton administration's contact with Jewish groups via personal ties and the White House Office of the Jewish Community Liaison, whose role often was to brief American Jewish leaders as well as defend the president's policies.

Finally, the research will use reporting from newspaper articles, editorials and opinion pieces in major American dailies, leading American Jewish newspapers, and magazines, including the Atlanta Jewish Times, Baltimore Jewish Times, Forward, Jewish Telegraphic Agency, ${ }^{49}$ New York Jewish Week, New York Times, and the Washington Post, among others. These latter sources often give a strong snapshot of how rank and file Jews are reacting to events, giving depth to - and sometimes contrasting with - the perspective of national Jewish leadership. The work also will make use of major Israeli newspapers such as Ha'aretz and the Jerusalem Post, as well as Israeli journals and magazines such as Israel Affairs and the Jerusalem Report for their

in North America. The CRCs are the public policy/intergroup relations agencies of local Jewish federations.

${ }^{49}$ The Jewish Telegraphic Agency, also known as the JTA Wire Service or simply JTA, is the international wire service (and now website at www.jta.org) that has a cooperative with North American Jewish newspapers, often known as the "Anglo-Jewish media." Its articles are widely circulated amongst Jewish leadership and local reporting often is line with the national pattern via localizing national stories or by feeding JTA with local related reaction pieces. 
perspectives on American Jewish attitudes toward Israel. In addition, journals that often focus on American Jewish affairs from different partisan perspectives, such as Commentary and Tikkun, will be looked at as well. 


\section{Chapter II. U.S. Jewry On the Eve of Oslo}

\section{II.1 The Importance of American Jewry in the U.S. Political Lanscape}

American Jewry's important role in national politics had been well-established by the early 1990s. As David G.Dalin wrote in 2001, "In many respects, the 1990s were a historic - indeed, a golden era for Jews in American politics and government." ${ }^{" 50}$ It was in fact a remarkable period for Jews as individuals in the government and political parties, as well as an identified and desirable bloc in the U.S. electorate.

As individuals, Jews had unquestionably risen to the top of the U.S. government bureaucracy and politically appointed positions. For example, in Bill Clinton's two cabinets there were five Jews, including Treasury Secretary Robert E. Rubin, Labor Secretary Robert Reich, and Agricultural Secretary Dan Glickman. ${ }^{51}$ Further, the two U.S. Supreme Court Justices appointed by Clinton - Ruth Bader Ginsburg and Steven Breyer -- were Jewish. In addition, in 1993 there were 10 Jews in the U.S. Senate and 31 Jews in the House of Representatives. Thus, while representing around 2 percent of the U.S. population, Jews comprised 10 percent of the upper chamber and about 7 percent of the lower one. Many more Jews sat in the seats at State Houses around the country.

Many of these elected officials were well-connected to Jewish organizations and Judaism played an important role in their personal lives. The prime example came at the

\footnotetext{
${ }^{50}$ David G. Dalin, “At The Summit: Presidents, Presidential Appointments and Jews,” in Jews In American Politics, Eds. L. Sandy Maisel and Ira N. Forman. (Lanham, Md. - Rowman \& Littlefield Publishers, Inc., 2001), p. 46.

${ }^{51}$ In addition, the two most prestigious positions in the Clinton cabinet - Secretary of State and Secretary of Defense - were respectively filled at one point by Madeleine Albright and William Cohen, both of whom had Jewish ancestry. Further, cabinet-level rank was given to Office of Management and Budget Director Jacob J. Lew and U.N. Ambassador Richard Holbrooke. Numerous other high ranking officials in the State Department who achieved ambassador status and were Jewish included Stuart Eizenstat, Martin Indyk, Dan Kurtzer, and Dennis Ross.
} 
end of the Oslo years when Sen. Joseph I. Lieberman (D-Conn.) would make a celebrated (among Jews) vice presidential run for the Democratic Party with Al Gore - a Southern Baptist -- in the 2000 national elections. David M. Shribman captured the powerful meaning of Lieberman's candidacy to both American Jews and America as a whole in the prologue to Jews In American Politics. When it came to how co-religionists viewed Lieberman, he wrote:

“He keeps kosher. He walks to shul. He doesn't campaign on Saturdays. He has a wife named Hadassah. He gabs in Yiddish. Mainstream historians will remember the 2000 campaign for its emptiness, its closeness, its flirtation with endlessness. But Jews will remember it for the Democratic vice-presidential nomination and for his Jewishness. ${ }^{52}$

The fact that Shribman declared non-Jews would not remember Lieberman for his Jewishness is testimony of the wide acceptance of Jews into the American mainstream. Indeed, for the vast majority of non-Jewish Americans, pondering whether to vote for a ticket with this very visibly Jewish candidate on it - which if successful could put Lieberman within a heart's beat of the presidency, and did in fact set him up for a presidential run in 2004 - just did not matter. As Shribman quotes Lieberman from a speech in the Senate chamber after the contested election results were decided, "While my faith was the focus of much of the early media reaction to my candidacy, it was not even mentioned at the end of the campaign." ${ }^{53}$ Lieberman's religious practice was actually so prominent in the 2000 campaign's early phase - due to his own emphasis on it

\footnotetext{
${ }^{52}$ David M. Shribman. "The Lieberman Candidacy," in Jews In American Politics, p. xxv.

${ }^{53}$ Ibid, xxvi.
} 
in speeches -- that Anti-Defamation League Director Abraham Foxman (himself an observant Jew), asked the Senator to stop making "overt expressions" of religion. ${ }^{54}$

Surely, this was reflective of an era in which Jews had risen to the top of the American political apparatus. After all, a Jewishly observant vice presidential candidate was running around using Yiddish words such as chutzpah and was chided for it in the New York Times by another observant Jew who happened to be the nation's major voice in the fight against anti-Semitism, as well as a strong advocate of maintaining the separation of religion and state.

It was not just politicians, however, who reflected the rise of Jews in the political apparatus. Jews as voters were seen as desirable by both major political parties. This was due in part to the concentration of Jews in states often critical to gaining Electoral College votes - such as California, Florida, New York and Pennsylvania. Jews also were known as major donors and fund raisers for campaigns, which in turn encouraged the major parties to set up well-financed efforts to persuade Jewish voters to support their candidates. $^{55}$

In fact, in 1990 the National Jewish Democratic Council (NJDC) came into being. Five years earlier, the GOP had formed the Republican Jewish Coalition (RJC). Both

\footnotetext{
${ }^{54}$ Lieberman's remarks must be seen in the context of a presidential campaign in which religion had become a major issue, which reflected the rise of the GOP's Evangelical base. That is, Democrats, too, wanted to show that they would not push religious beliefs out of the public square. After all, Republican candidate Gov. George W. Bush had earlier in the campaign referred to Jesus as his favorite philosopher. In addition, in front of the U.S.-based Jewish group B'nai B'rith International, he said, "Our nation is chosen by God and commissioned by history to be a model to the world of justice and inclusion and diversity without division. Jews and Christians and Muslims speak as one in their commitment to a kind, just, tolerant society." Gustav Niebhur, "Lieberman Is Asked To Stop Invoking Faith In Campaign." New York Times, 29 August 2000.

${ }^{55}$ The 2000 presidential campaign was illustrative of the importance of courting Jewish votes. Ballots in heavily Jewish Florida districts became the crux of numerous local recount efforts and subsequent court battles.
} 
partisan groups were charged with raising the profile of their party with money from American Jews. They sought to accomplish this via building chapters around the country, holding events in cities without full-fledged chapters, and gaining media attention, particularly in local Jewish newspapers. During presidential conventions, a high-ranking representative of a candidate or the candidate himself often stopped by an official NJDC or RJC event held for Jewish delegates. Finally, both the NJDC and RJC were busy throughout the year reaching out to Jewish newspaper editors, on whose pages they hoped to persuade the broader community by influencing editorials and reported articles, or through paid advertisements. Beginning in the mid-1990s, both operations began making their latest stands and related background material available through their websites -- www.njdc.org and www. rjc.org. Finally, it was not uncommon for an NJDC or RJC official to stop by the annual American Jewish Press Association convention to network his or her cause amongst the editors present or to develop a professional relationship with newspaper editors in various cities.

For certain, everyone in politics understood that Jews were generous donors to campaigns in both parties. This had already been noted in a study of the 130 people who had served as a U.S. Senator from 1970 to 1982. It found that voting in a "“pro-Israel" manner - backing arms sales to Israel, opposing arms sales to Arab states, resisting administration efforts to pressure Israel" brought more contributions from "Jewish sources," which were defined as pro-Israel Political Action Committees and "donors with Jewish surnames.” In fact, 10 of the Senators with the strongest pro-Israel records received 15 percent or more of monies donated to their campaign from Jewish sources. 
By contrast, 53 Senators who gained under 2 percent of their funding from these same sources voted pro-Israel only about half of the time. ${ }^{56}$

So not surprisingly, during presidential campaigns intense media scrutiny on a candidate's stands on Israel and relationship to American Jews was standard, as was an appearance at the annual spring American Israel Public Affairs Committee (AIPAC) policy conference in Washington, D.C.. The speech a candidate gave there always made national headlines and was heavily analyzed by American Jewish organizations and the Israeli government. A typical example came on May 27, 1999 with the arrival of Vice President Al Gore, already a presidential candidate for the next year's election, at AIPAC's event. Gore wasted no time assuring the more than 3,000 people present that their concerns were his concerns. In describing his arrival in Congress 22 years earlier from a district with very few Jews, he said in only the second paragraph of his speech:

"That meant, of course, that on legislation relating to Israel I had very little input from my own constituents. I just voted my instincts. I voted my conscience. I voted the national security interests of the United States. I soon found that my instincts and my conscience and my sense of America's national security needs put me in alliance with all of you...

"I share your love for Israel, your energetic, enduring support of the U.S.Israel partnership, and I salute you for coming here to Washington every year for one of the key cornerstones of America's national security - a strong, secure, peaceful and prosperous State of Israel., 57

\footnotetext{
56 J.J. Goldberg, Jewish Power: Inside the American Jewish Establishment (Reading, MA: Addison-Wesley Publishing Co., 1996), pp. 266-267. The author is citing the work of political scientist A.F.K. Organski of the University of Michigan. Organski found that "Jewish and pro-Israel campaign funding goes mainly to lawmakers who have already shown they are pro-Israel." Thus, the money does not sway views, but helps in the effort to keep the pro-Israel community's friends in power. Goldberg, p. 267.

${ }^{57}$ Gore, Albert. “Text: Vice President Gore’s Remarks At AIPAC Conference, May 23.” Web. 15 January 2009.
} 
Finally, the importance of Jews in the electorate also is notable by the White House designation of a Jewish community liaison, an individual charged to meet with and update Jewish organizational leaders to explain and advocate an administration's positions - particularly when it comes to Arab-Israeli peace process initiatives. ${ }^{58}$

\section{II.2 A Disproportionate Influence On The Electorate}

Such attention paid to American Jews is remarkable when considering their numerical standing in the U.S. population alone. Indeed, at the height of American Jewry's numerical strength back in the 1930s and 1940s, they were only about three percent of the overall population. ${ }^{59}$ Today, if one takes a rounded estimate of six million American Jews - various population surveys have them ranging from 5.2 million (the 2000-2001 National Jewish Population Study) to 6.7 million (the “American Jewish Identity Survey 2001” by Egon Mayer and Barry Kosmin) - Jews constitute roughly two percent of the 300 million U.S. citizens. ${ }^{60}$

Even more remarkable is that when using the standard +- 4 point margin of error in most demographic studies, American Jews could be considered statistically negligible.

\footnotetext{
${ }^{58}$ While often in the last century an individual has been designated as an unofficial liaison to the Jewish community - often a Jew within the cabinet such as Secretary of Treasury Henry Morgenthau during the Franklin D. Roosevelt era, the task became a formal position only in the Reagan White House (1981-1989) when Marshall Breger was appointed to that position. The noted attorney and scholar is widely seen as having been the most senior and effective person in the position to date. The White House does have liaisons to other communities as well, such as the Hispanic, Asian-American, Pacific-islander communities.

${ }^{59}$ Goldberg, p. 253.

${ }^{60}$ There is a debate amongst Jewish demographers and policy makers as to whether "the Jewish community" includes self-identified Jews, "people in households with Jews," people who are involved in Jewish life on some level, and various derivations of such categories. This debate does not deal with the more complicated "Who is a Jew?" issue, which becomes a theological issue in the United States and a theo-political one in the State of Israel.
} 
Were one to err the other way, they would at most comprise 6 percent of the national population. Further putting their political strength into perspective is that this higher number does not equal even half of that of the African-American community, which has nowhere near the major impact on a single issue as does the Jewish community on U.S. policies regarding Israel. (When one includes estimates of the widely cited statistic of at least 10 million illegal immigrants in the country, the Jewish percentage of the population dips farther, although this obviously does not affect the percentage of registered voters.)

Further, something of which Jewish community activists are keenly aware of is that at any given time roughly only half of American Jews are said to be affiliated with the organized community, which is defined as membership in any organization synagogue, Jewish community center, simply paying dues to a Jewish organization (regardless of activity level), etc. In fact, the 1990 National Jewish Population Study by the Council of Jewish Federations found that only one-third of "core Jews" - defined as those born Jewish and still self-identified as Jewish, secular-ethnic Jews born Jewish but not considering themselves religious, and Jews by Choice (converts by rabbis of any denomination) - reported that they belong to a synagogue/temple or Jewish organization. $^{61}$

Helping make what Jewish newspaper journalist and author J.J. Goldberg has termed "Jewish power" in national politics so effective is that leading Jewish activists in both major political parties often were simultaneously veteran leaders of organized

\footnotetext{
${ }^{61}$ Sidney Goldstein, "Profiles of American Jewry: Insights from the 1990 National Jewish Population Study," in American Jewish Yearbook: Volume 92. (New York: American Jewish Committee, 1992), p. 140. However, in functional terms these numbers are likely higher as a number of Jews in any community participate in synagogue and organizational Jewish life without paying dues or making annual donations. Likewise, they may not be paying such funds in one year, but have done so for many years and still have a loyalty to such organizations - as well as join up again in the future, or make periodic donations.
} 
Jewish life. That obviously made these individuals sensitive to both Jewish community concerns and a bridge for their political parties' outreach to Jewish voters. A prime example on the GOP side was Max Fisher (1908-2005), the Detroit philanthropist who was a confidante of Republican presidents such as Richard Nixon (1969-1974) and Ronald Reagan (1981-1989). He was not only the driving force behind the founding of the RJC, but a venerated figure in communal affairs. At the time of his death, he served as honorary chairman of the United Jewish Communities. From 1965-1972 he had held the top volunteer positions in national Jewish organizations such as the United Jewish Appeal, Council of Jewish Federations and United Israel Appeal. On the other side of the aisle, Steven Grossman (b. 1946-present) stands out. The Boston-based philanthropist served as national chairman of AIPAC (1992-1997), which put him front and center during Oslo's formation and initial years, and then national chair of the Democratic Party (1997-1999) - both volunteer positions in which fundraising was a major goal and in which he interacted with both key American and Jewish leaders.

\section{II.3 Israel On The Agenda}

Just as Jews as both individuals and an organized community were undeniably a factor in national political affairs, one cannot overlook the primacy of pro-Israel activism on the Jewish agenda. ${ }^{62}$ In fact, in the decades leading up to the Oslo years, the wellbeing of the State of Israel had become central to American Jewry's philanthropic,

\footnotetext{
${ }^{62}$ For more on the background of how this came to be as well as the standing of Israel in various U.S. administrations and in the eyes of the American public, see Peter Grose, Israel In the Mind Of America. (New York: Knopf, 1983).
} 
political and educational structure. ${ }^{63}$ As the sociologist Nathan Glazer observed, by the end of the 1970s for many American Jews support for Israel had become the religion. ${ }^{64}$ Indeed, the hyper-focus of American Jews on the pro-Israel agenda in the political realm is a facet of what Jonathan Woocher, long-time director of Jewish Educational Services of North America, has called American Jewry’s "civil religion."65

That was, however, not always the case. Until the 1967 Six-Day War, there had been either ambivalence or outright hostility from some segments of the American Jewish community toward the Jewish state. When it came to ambivalence, after the intense years of fighting (and infighting) regarding the establishment of the State of Israel, American Jewry turned inward. Many were simply focused on personally furthering their economic standing and communally on building their institutions, such as synagogues and social service delivery agencies. Meanwhile, their spare time was spent socializing in membership organizations such as B'nai B'rith bowling leagues, or at the regular neighborhood synagogue sisterhood or brotherhood events.

A small, vocal number of Jews vociferously took up the cause of distancing themselves from even the concept of a Jewish state. The strongest reactions came from

\footnotetext{
${ }^{63}$ Chaim I. Waxman, "Center and Periphery: Israel in American Jewish Life," in Jews in America: A Contemporary Reader, Eds. Roberta Rosenberg Farber and Chaim I. Waxman. (Hanover, Conn.: University Press of New England, 1999), p. 212.

${ }^{64}$ Ibid, p. 214, citing Nathan Glazer, “American Jews: Three Conflicts of Loyalties," in Seymour Martin Lipset, ed., The Third Century: America as a Post-Industrial Society. (Stanford, Calif.: Hoover Institution Press, 1979), p. 233.

${ }^{65}$ Martin J. Raffel. “American Jewish Public Affairs and Israel: Looking Back, Looking Ahead.” The Reconstructionist (Spring 1998), p. 60. For more, see Jonathan Woocher, Sacred Survival: The Civil Religion of American Jews. (Bloomington, Ind. : Indiana University Press, 1986).
} 
opposite ends of the religious spectrum - elements within the ultra-Orthodox (Haredi) community and the "classical Reform" wing of Reform Judaism.

Until effectively dissipating in the late 1960s (following the Six Day War), the American Council for Judaism - originally founded by a handful of Reform rabbis - was a visible leader in the anti-Zionist effort. Its leadership, arguing from the classical Reform perspective's interpretation of prophetic Judaism, declared that the Jews' great global cause was to spread the values of social responsibility as espoused by the Hebrew Bible's prophets. To do so, these rabbis continued, Jews must reside everywhere and be loyal citizens of their countries; it was believed that having their loyalty questioned by advocating on behalf of a Jewish state would hurt their cause. At one point, this movement attracted the attention of some leading American Jews, including New York Times publisher Arthur Hays Sulzberger (1891-1968). ${ }^{66}$

The theological foundations of such beliefs were enshrined in the 1885 Pittsburgh Platform of the Central Conference of American Rabbis (CCAR), Reform Judaism's professional rabbinical association. Specifically addressing the nascent modern Zionist movement, it declared that nationalism violated the spirit of Judaism because "we consider ourselves no longer a nation, but a religious community, and therefore expect neither a return to Palestine, nor a sacrificial worship under the administration of the sons of Aaron, nor the restoration of any of the laws concerning the Jewish state."67

\footnotetext{
${ }^{66}$ Grose, pp. 225-227. For more on the American Council for Judaism, see Thomas Kolsky, Jews Against Zionism: The American Council for Judaism (1942-1948). (Philadelphia: Temple University Press, 1990). As of this writing the Council remains active and maintains the website www.ajcna.org.

${ }^{67}$ Marc Lee Raphael, Profiles in American Judaism: The Reform, Conservative, Orthodox, and Reconstructionist Traditions in Historical Perspective. (San Francisco: Harper \& Row Publishers, Inc., 1984), p. 28.
} 
Yet by 1937, Reform was changing in America due to factors including the influx of more traditional Jews with eastern European roots (where Zionism was strongest) and the increasing restrictions on Jews in Nazi-controlled Germany, which strengthened the argument for a Jewish refuge in Palestine, if not an independent Jewish state. As a result, the CCAR's 1937 Guiding Principles, dubbed the Columbus Platform for the Ohio city in which the rabbis met, called Palestine a land "hallowed by memories and hopes" and affirmed an "obligation" to make it a "Jewish homeland" that was not only a "haven of refuge for the oppressed," but a "center of Jewish culture and spiritual life."68

By 1969, with the Jewish state already in its second decade and having survived the tumultuous 1967 Six Day War, the Reform movement formally declared Israel Independence Day an official holiday to be celebrated by its congregations. One year later, the U.S. Reform rabbinical seminaries made a year of study in Israel obligatory for students, which enhanced their Hebrew literacy and gave them intimate awareness of the Jewish state's challenges, attributes that would obviously impact their service to congregations in the future. ${ }^{69}$ As a result, congregants of such rabbis were able to gain more informed opinions. In addition, many such attitudes were further shaped by congregational trips to Israel led by various rabbis, often ones that featured the Reform movement's activities and struggles in Israel. Reflective of all this, in 1978 the Association of Reform Zionists of American was formed.

\footnotetext{
${ }^{68}$ Ibid, p. 46. The platform did not specifically call for a "Jewish state," which was by this time the wellestablished goal of the international Zionist movement.

${ }^{69}$ Ibid, pp. 62-63. Previously the year in Israel for Reform rabbinical students was optional.
} 
In many regards, any distancing from the fate of the Jewish state was effectively over in the broad scope of mainstream American Jewry.

Those official declarations, as is often the case, reflected the established practices of an increasing number of congregants and spiritual leaders. In fact, in the preceding decades leading Reform rabbis and activists had taken top leadership positions in Zionist organizations. Prominent examples included Rabbi Stephen S. Wise, Rabbi Abba Hillel Silver, and U.S. Supreme Court Justice Louis Brandeis.

While diametrically opposed to Reform Judaism theologically, a much smaller group of ultra-Orthodox Jews practiced what Aviezer Ravitzky has called "radical antiZionism." The main proponents of this were and are the Neturei Karta, the Edah Haredit and the Satmar Hasidim, all groups that remain anti-Zionist to this day. ${ }^{70}$ Members of the Neturei Karta in particular are the most active on this front, as well as visible at various anti-Israel rallies in New York City, London, Jerusalem and elsewhere.

\section{II.4 The 1967 Revolution}

As mentioned, the nervous build-up to and then the triumphant battles of the 1967 war all but eradicated both the hostility and even ambivalence amongst American Jews who did not already consider themselves Zionists. Indeed, the powerful emotions conjured by a biblically significant and triumphant six-day campaign - echoing the period of creation in the Hebrew Bible - enthralled and captivated American Jews and much of the world. One poignant example came with the publishing of Israel: Echo of

\footnotetext{
${ }^{70}$ For the theological basis and historical development of Orthodox anti-Zionism, see Aviezer Ravitzky, Messianism, Zionism, and Jewish Religious Radicalism (Chicago: The University of Chicago Press, 1993), pp. 40-78.
} 
Eternity, by Rabbi Abraham Joshua Heschel, the influential Jewish Theological Seminary rabbi known for combining spirituality and civic activism in advocating for the Civil Rights movement and against the Vietnam War. As Heschel wrote about his visit to Jerusalem just after the war, the challenge now for Diaspora Jews "is the deep personal involvement of every Jew in the existence of Israel. It is not a matter of philanthropy or general charity but of spiritual identification." ${ }^{\text {71 }}$ Thus, for him aiding the State of Israel itself had become an integral pillar of modern Jewish identity; likewise, Israelis saw this as a central responsibility of diaspora (particular American) Jewry.

This solidification of the Jewish community's pro-Israel agenda only increased in the coming years. By 1989, an American Jewish Committee survey had found that 73 percent of respondents agreed that caring about Israel was a "very important part of my being a Jew." ${ }^{, 72}$ A little more than a decade later, the 2000-2001 United Jewish Communities National Jewish Population Study found that 81 percent of American Jews felt that being Jewish "involves caring about Israel." ${ }^{, 73}$ Further, around the same time the 2000 American Jewish Committee Survey of Jewish Opinion found that 74 percent of American Jews felt either "very close" or "fairly close" to Israel while only 25 percent felt "fairly distant" or "very distant." 74 When one considers that at any given time less than one-half of American Jews were affiliated with the organizational community, such

\footnotetext{
${ }^{71}$ Abraham Joshua Heschel, Israel: An Echo of Eternity (New York: Farrar, Straus and Giroux, 1973) p. 224.

${ }^{72}$ Cohen, Steven M. “Ties And Tensions: An Update: The 1989 Survey of American Jewish Attitudes Toward Israel. (New York: American Jewish Committee, 1989),

73 2000-20001 National Jewish Population Survey. (New York: United Jewish Communities, 2002), p. 7.

${ }^{74} 2000$ Survey of American Jewish Opinion. (New York: American Jewish Committee, 2000), p. 1.
} 
statistics point to strong residual attachment to Israel regardless of an individual's level of communal engagement.

Such beliefs were reflected in the orientation and activities of organized American Jewry as well. Indeed, connection to and concern for the State of Israel's well-being was an omnipresent factor on organized American Jewry's agenda. In fact, only events in Israel - and the response of the U.S. government - could bring out the masses to proIsrael rallies on but a few day's notice, ${ }^{75}$ such as happened on April 15, 2002 as Israeli troops returned to the West Bank in Operation Defensive Shield to counter a devastating string of Palestinian terrorist suicide bombings. Numerous smaller local rallies dotted the country either in response to a particular event, such as the Rabin assassination in 1995 or annual Israel Independence Day celebrations, the latter a staple on North American Jewish community calendars.

Any peripheral survey of the activities of major American Jewish organizations during this period clearly reflects such Israel focus. Some brief examples included:

- The major portion of the relationship between Presidents Conference members and the White House Liaison on Jewish affairs is consumed with discussions on Israel policy.

- A large focus of the American Jewish Committee's international diplomatic outreach is pro-Israel activism.

\footnotetext{
${ }^{75}$ While Soviet Jewry rallies, such as the December 6, 1987 one in Washington, D.C., brought out estimates of more than 200,000 people, it was planned for months to coincide with the visit of then-Soviet Premier Mikhail Gorbachev who was beginning to loosen the strict emigration regulations of recent years. In addition, former Prisoner of Zion Anatoly (Natan) Sharansky, for American Jews an extremely charismatic figure and symbol of Soviet Jewry's struggles, had been drumming up support for such an event for a year, speaking at venues such as the Baltimore Jewish Festival the previous summer.
} 
- The Anti-Defamation League puts a large focus on monitoring anti-Israel activity by journalists, cultural elites and political figures.

- B'nai B'rith International's office at the United Nations, which once spent much focus on the Soviet Jewry cause, is principally focused on helping Israel at the world body.

- AIPAC, arguably the most effective lobby in Washington, is solely focused on Israel. $^{76}$

Meanwhile, the daily rhythm of American Jewish life was replete with education on and promotion of the State of Israel's well-being. To enhance such connections, by the 1990s, a trip to Israel had become a right of passage for "committed Jews" and their families. So it was not surprising that a 1995-1996 study of Conservative Jews found that 81 percent of children about to have or who had just had a bar or bat mitzvah said they were willing to visit Israel with a teenage group. (While it might seem obvious that they would agree to go, the high percentage meant that Jewish education for the moment had their attention). Even more encouraging is that 73 percent said their parents discussed Israel and current events in the Middle East with them, and a surprising 75 percent said they would like to speak conversational Hebrew. ${ }^{77}$ In addition, study of modern Hebrew

\footnotetext{
${ }^{76}$ The most noted example of AIPAC's effectiveness is the "congressional role call" at the banquet of its annual policy conference. One by one, the names of representatives present are announced from the dais to the scattered applause of their constituents and acquaintances among the often 5,000 diners present. Likewise, administrations send top policy makers - if not the president or vice president - to address the conference. An appearance by a U.S. Secretary State is an expected and anticipated event, as is a showing of the Israeli prime minister (if not in person than by video hookup).

${ }^{77}$ Jack Wertheimer, Conservative Synagogues and Their Members (New York: Jewish Theological Seminary of America, 1996), p.28. Transferring such desires into action increasingly became a focus of the organized Jewish community and a small group known as "mega-donors" during this period through what would become the Taglit-Birthright Israel free 10-day trips to the Jewish state for young adults, aged 18-26 who had not previously taken such a journey on a trip with peers.
} 
became more common on secular college campuses, having expanded greatly in the 1970s, as did studies of Israel and Middle Eastern affairs. Not surprisingly, these efforts were often funded via new institutes or endowed chairs thanks to Jewish donors interested in finding new venues to deliver Jewish education in ways palatable to the recipients.

These developments echoed the long-standing tradition of supporting Jews in the Land of Israel for much of the past century, as best evidenced by the familiar Jewish National Fund pushkes, or coin boxes of donations sent to help fund efforts to "reclaim the land." The blue and white boxes were and remain common in countless Jewish homes, synagogues and organizational offices. Meanwhile, planting trees in Israel to mark a bar or bat mitzvah and other simchot (joyous occasions) was standard. Likewise, in an indisputable nod to the financial clout of American Jewry, by the 1990s every major Israeli university and hospital had set up a "friends of" group in this country. Finally, every Jewish Federation in North America expected at one point their top leadership to visit Israel on a mission in which they would be shown how their funds were helping the Jewish state.

\section{II.5 Fighting For Political Loyalties}

While American Jews were at the forefront of national politics, and the State of Israel was at the forefront of their advocacy agenda, their overall attachment to the Democratic Party also seemed unquestioned in this period. Indeed, by the Clinton White House of the Oslo years, American Jews were heavily valued as a voting bloc that was an 
important and loyal base for the Democratic Party. The results were clear: in the three presidential elections from 1992 through 2000, the Jewish vote for the Democratic presidential candidate was 80 percent, 78 percent and 79 percent. ${ }^{78}$

In fact, the Jewish-Democratic Party allegiance had been entrenched since early in the $20^{\text {th }}$ century. Since 1928 there was only one time when the Jewish vote dipped below 60 percent for a Democratic candidate. It even reached a high point of 90 percent in 1940 , 1944 and 1964. In 1980, the GOP thought it had cracked the Democratic lock on Jewish ballots when Jimmy Carter's reelection bid captured only 45 percent of the vote.

However, once again, a third party candidate - this time Democratic Congressman John Anderson, who ran as an Independent - siphoned votes, taking 15 percent of the Jewish electorate. That left 39 percent for Ronald Reagan, still not even a plurality of the Jewish vote. $^{79}$

Despite American Jewry's overwhelming electoral support for the Democratic Party, the GOP did not give up the hopes of gaining Jewish votes and financial support. The pro-Israel agenda was clearly its most likely attraction for the Jewish community. That is the point the scholar Daniel Pipes tried to emphasize in his October 1992 article in Commentary magazine - appearing just before the national elections. In tracing the Israel stands of the two major U.S. political parties, he said the tide had turned to the GOP when it came to standing with Jerusalem in good and bad times.

\footnotetext{
${ }^{78}$ Ira Forman, Jews In American Politics, eds. L. Sandy Maisel and Ira N. Forman. (Lanham, Md.: Rowman \& Littlefield Publishers, Inc., 2001), p. 153.

${ }^{79}$ Ibid, p. 153. The one exception that proved the proverbial rule of Jewish support came in 1920 , and even that was an endorsement of Democratic support. Back then, only 19 percent of the Jewish vote went for the Democratic candidate. However, that was augmented by 38 percent for Socialist Party candidate Eugene Debs, giving a total of 57 percent of the vote not going to the Republican candidate.
} 
The Republican move toward a pro-Israel stand represents an evolving long-term commitment. Though far from unanimous, the direction is clear. The Democratic position, in contrast, shifts opportunistically. At this moment, to be sure, forces friendly to Israel can out-muscle the opposition. But watch out. Just as soon as isolationist impulses grow stronger or Arab-Americans get organized, the pro-Israel stand will evaporate as quickly as ice on a summer afternoon in the Negev. ${ }^{80}$

Nonetheless, while the Republicans already had a strong following amongst Orthodox Jews (only 10 percent of the U.S. Jewish population), the party had little hold on the rest of American Jewry. Besides, the GOP did not favor pro-Israel stands just to gain Jewish votes. It This also satisfied the party's evangelical Christian base. Likewise, many Republicans were staunch supporters of Israel for its status as the only democracy in the Middle East, a time-tested partner in the Cold War and because of the general national sympathy for the plight of Soviet Jewry. ${ }^{81}$

\section{II.6 Loan Guarantees Battles}

A clear example of where the agenda of the organized Jewish community and the GOP would clash, came during the 1992 presidential campaign. By the early 1990s, American Jews and their allies could deem the movement to enable free emigration for Soviet Jewry a success. The gates of emigration for Jews from Eastern Europe had been flung open as part of Soviet Premier Mikhail Gorbachev's outreach to the West. For American Jewish activists, it was the realization of a long-sought dream. Indeed, in the 1970s and 1980s the freedom for Soviet Jewry movement had become a focus for North

\footnotetext{
${ }^{80}$ Daniel Pipes, “Bush, Clinton, and the Jews," Commentary 94.10 (1992): 19.

${ }^{81}$ Robert O. Freedman. "Soviet Jewry as a Factor in Soviet-Israeli Relations," in Soviet Jewry in the 1980s and the Dynamics of Resettlement. (Durham, N.C.: Duke University Press, 1989), pp. 61-96.
} 
America's Jewish community relations councils (CRCs), campus Hillel houses, and in D.C. lobbying. Bar and bat mitzvah children were dedicating their event to a peer in the Soviet Union. Every day (other than on Saturday, the Jewish Sabbath, and Jewish holidays) Jewish protestors picketed across from the Soviet embassy on $16^{\text {th }}$ Street in Washington, D.C.

Portraying the emotions the campaign raised, Shoshana S. Cardin wrote that as the emigration gates opened, "The American Jewish community could be proud. We had faced down Soviet oppression and had succeeded in rescuing an endangered Jewish community of historic size. ${ }^{\nexists 22}$ Likewise, her description of the motivations for being involved in the cause was reflective of American Jewry as a whole and certainly its leadership: "From the beginning," she wrote, "my interest in the problems of Soviet Jewry were personal: members of my father's family still lived there, and I was concerned about them." 83

A positive result of the open emigration policy rarely commented upon is that it effectively ended the noshrim battles between American and Israeli Jews. In that struggle, Israeli Jews expressed their anger with their American counterparts for seemingly luring Soviet Jews away from the Jewish state with attractive benefits such as help with housing, work and free memberships to Jewish institutions. ${ }^{84}$ Washington now limited to

\footnotetext{
${ }^{82}$ Cardin, p. 124. During the late 1980s, Cardin had served as national president of the National Council for Soviet Jewry, which was the main arm of Soviet Jewry activism amongst American Jewry. Its counterpart the Union of Councils for Soviet Jewry - was seen as more hard-line in its demands for action and much more of a grassroots organization than NCSJ, which was funded by the Council of Jewish Federations.

${ }^{83}$ Ibid, p. 111. Also, the passions the freedom for Soviet Jewry movement aroused in the United States were seen at a December 6, 1987 rally in Washington, D.C.

${ }^{84}$ The tensions between American Jewry and the Government of Israel had become so pronounced that a joint U.S.-Israeli committee of Jewish activists was formed and recommended that American Jewish groups
} 
50,000 annually the refugee visas for Soviet Jews who could prove "'a well-founded fear of persecution." ${ }^{, 85}$ When it came to the large numbers of Soviet Jews seeking exit visas, Israel was their only practical destination. In fact, the Jewish state was literally being transformed with the arrival of hundreds of thousands of Soviet Jews.

That set the stage for the loan guarantees battle. With Israel absorbing so many new immigrants so quickly, it notified the Bush administration that it would be seeking from Washington a very large loan guarantee for money that it would borrow from banks to build infrastructure needs such as housing and roads to help resettle the new immigrants. ${ }^{86}$ There was precedent for such action in that on May 25, 1990 the Bush administration had approved $\$ 400$ million in loan guarantees "for the purpose of providing housing and infrastructure for Soviet refugees." ${ }^{87}$ A telling stipulation in that earlier agreement, however, came with the provision that the funds should not be used over the "Green Line" (Israel's pre-1967 border) to expand existing and build new Jewish settlements, venues that sought to strengthen themselves with the former Soviet residents. As U.S. Secretary of State James Baker, III wrote, "unfortunately these pledges were

end such aid. However, the boards of the American Jewish Joint Distribution Committee and the Hebrew Immigrant Aid Society - both U.S.-based operations - rejected the proposal. Likewise, the Israeli government indicated its belief that Soviet Jews being permitted to divert themselves to the West had led to a drop off in emigration visas being granted. Robert O. Freedman, "Soviet Jewry as a Factor in SovietIsrael Relations," in Soviet Jewry in the 1980s: The Politics of Anti-Semitism and Emigration and the Dynamics of Resettlement, Ed. Robert O. Freedman (Durham, N.C.: Duke University Press, 1989), pp. 7981.

${ }^{85}$ Robert Pear, "U.S. Drafts Plan to Curb Admission of Soviet Jews.” New York Times. 3 September 1989, and Joel Brinkley, "Soviet Jews Leave At Record Pace, Mostly For Israel." New York Times. 14 December 1989.

${ }^{86}$ Israel's population at the end of 1987 was 4.4 million. At the end of 1997, it was 5.9 million, reflecting the dramatic impact the Soviet immigration was having on growth. In fact, in 1990 alone Israel's population grew by 200,000 for a 6.2 percent overall increase. Nurit Yaffee, "The Israeli Population," Tzohar (Jerusalem: State of Israel Central Bureau of Statistics, 1999). Web. 12 January 2009.

${ }^{87}$ Reuters, “Baker Agrees To Housing Aid For The Israelis.” New York Times. 3 October 1990. 
disregarded." That resulted in the U.S. government declining to release the original loan guarantees. ${ }^{88}$

Nonetheless, on January 22, 1991 Yitzhak Shamir's government informed the White House that it would formally request a $\$ 10$ billion guarantee later in the year. This took place in the context of an already acrimonious relationship between Washington and Jerusalem. The tensions had become so high that Baker seriously considered recommending to Bush that Israeli Ambassador Zalman Shoval be declared persona non grata status by the U.S. government. This came after Shoval told the Washington Post that the U.S. administration's cool reception to Israel's request gave him the feeling that his country was being given the "runaround" and that Israel had yet to receive "one cent of aid" to compensate for losses such as tourism as a result of the Gulf War. As Baker sarcastically wrote, “It was quite a Valentine’s Day present from a close ally." 89

Further, from the perspective of the U.S. government, Israel's request was extremely ill-timed, having been made only six days after the beginning of the 1991 Gulf War. The Bush administration wanted Shamir to delay the request, which would avoid tensions with Arab states that could both scuttle the U.S.-led coalition against Saddam Hussein's forces and the expected post-war effort to bring Israel and her Arab neighbors into a peace process. That would mean delaying what would be seen as provocative

\footnotetext{
${ }^{88}$ James A. Baker, III. The Politics of Diplomacy: Revolution, War and Peace 1989-1992. (New York: G.P. Putnam's Sons, 1995), pp. 543-45.

${ }^{89}$ Ibid, pp. 545-547. In calling Shoval in for a "formal dressing-down," Baker chided Shoval for going to the press and ignoring America's deployment of Patriot missile batteries on Israeli soil, which endangered the U.S. troops manning them, and Washington's Gulf War alliance that sought to remove Israel's "foremost strategic threat" in the form of Saddam Hussein. Finally, he left Shoval with this stinging reminder: "You don't have anyone in this administration who's going to go out and get you the money if I don't." (The emphasis is Baker's.)
} 
moves, a category in which the Bush administration clearly put the Israeli loan guarantees. As Baker wrote 13 years later, he had repeatedly heard from Arab governments that approving Israel's request would jeopardize the U.S. ability to be perceived as an unbiased broker. "Publicly," he wrote, "we said the United States would 'fully consider' the [Israeli] request. But we had no intention of doing so until a more appropriate moment." 90 Echoing the anger and confirming Baker's version of events, Dennis Ross, then the Secretary of State's coordinator of Middle East policy, wrote that he had told Bush that Shamir "would be a fool to jeopardize [loan guarantees] by violating the terms of the Levy letter," in which Baker and Israeli Foreign Minister David Levy agreed that Israel would give advance notice to Washington regarding expansion of settlements and not use U.S. guaranteed money at such venues. "As it turned out," Ross continued, 'I was wrong... basically, Shamir's approach became one of stringing us along." Ultimately, Baker agreed to a compromise suggested by Sen. Patrick Leahy that called for a "dollar for dollar" deduction from the loan guarantees when Israel spent money on expanding settlements. ${ }^{91}$

In the past, the U.S.-led Middle East peace process had been stymied by the Soviet bloc. However, that was no longer the case. The Soviet Union was literally in its last months; it would cease to exist on December 25, 1991 when Soviet Premier Mikhail Gorbachev resigned and declared his office extinct. Meanwhile, U.S. prestige was soaring as Washington became the seat of the world's sole super power and could

\footnotetext{
${ }^{90}$ Ibid, p. 544.

${ }^{91}$ Dennis Ross. The Missing Peace: The Inside Story of the Fight for Middle East Peace. (New York: Farrar, Straus and Giroux, 2004), pp. 82-85.
} 
seemingly set the agenda. Indeed, just after the Gulf War's conclusion, President Bush in a March 6, 1991 speech to a joint session of Congress called for "a new world order." Part of it, he said, should feature new, robust efforts toward Arab-Israeli peace making, and the United States was willing to take the lead. As he said:

"In the conflict just concluded, Israel and many of the Arab States have for the first time found themselves confronting the same aggressor... A comprehensive peace must ... provide for Israel's security and recognition and at the same time for legitimate Palestinian political rights... The time has come to put an end to the Arab-Israeli conflict." 92

\section{II.7 American Jewry's Awkward Position}

The loan guarantees, however, had still not been granted to Israel. This put American Jewry in an extremely awkward position. It was asked to go against a wartime President and then a post-wartime President at the height of his popularity. Nonetheless, American Jewish groups moved ahead with a public battle to secure Israel's request, which would have to be approved by the U.S. Congress. AIPAC - officially charged by the New York-based Conference of Presidents of Major American Jewish organizations as the coordinator of Washington lobbying on policies to help the State of Israel - by the summer was meeting with State Department representatives Dennis Ross and Janet Mullins to further the request. As Baker tells it, these meetings were designed to persuade AIPAC, and by extension organized American Jewry, "that their timing was terrible, and that deferral was preferable to a fight that would be a lose-lose situation for all."

AIPAC's bravado came from its being told by some friends in the Congress that it could

${ }^{92}$ Cardin, p. 131, citing George H. W. Bush, "Address Before a Joint Session of the Congress on the Cessation of the Persian Gulf Conflict," March 6, 1991. While Israel was not formally part of the anti-Iraq coalition, it clearly wanted Saddam Hussein's forces - the strongest Arab army -- to absorb a punishing blow. 
win the fight. ${ }^{93}$ This reflected both a misunderstanding of American Jewry's realizations of the limits of its power and a sense of obligation to push for the Jewish state's most urgent need. Shamir himself saw American Jewry's dilemma in stark terms, saying that he understood "all too well the implication for American Jewry of what the President had said to them, which amounted to "Vote for me or for Israel.",94

There was some dissension amongst some smaller and liberal American groups who agreed with Baker that Shamir's government should not be allowed to use U.S. guaranteed funds to help build settlements. Prior to the mid-February 1992 NJCRAC plenum, the traditional arena for argument and the resulting quasi-consensus resolutions guiding organized American Jewish life, ${ }^{95}$ the AJCongress, UAHC, and community relations councils of Milwaukee and Detroit introduced a resolution explicitly urging a settlements freeze. The OU, however, termed that "an effort to undermine Israel" and Israeli government officials said that a vote against settlements would strengthen the Bush administration's hand in denying loan guarantees. Meanwhile, Americans for a Safe Israel (AFSI), a pro-Likud operation, released a poll showing that a solid majority of American Jews felt that "Israel should not give up any of the disputed territories." Some observers expressed doubt about the poll's validity. ${ }^{96}$

\footnotetext{
${ }^{93}$ Baker, pp. 548-549.

${ }^{94}$ Yitzhak Shamir, Summing Up. (Boston: Little Brown and Company, 1994), p. 235.

${ }^{95}$ NJCRAC at this time represented 117 local Jewish community relations councils and 13 national agencies.

${ }^{96}$ Lawrence Grossman, "Jewish Communal Affairs," in American Jewish Yearbook 1994 (New York and Philadelphia: The American Jewish Committee and The Jewish Publication Society, 1994), p. 184.
} 
The subsequent NJCRAC Joint Program Plan Committee, whose document provided policy guidelines and direction for local community relations councils during the year, brought a decision to not even vote on the question of settlements. Rather, it agreed to send a transcript of the discussion to the Israeli government if the highly unlikely threshold of two-thirds approval by a NJCRAC plenum was not met on the proposed resolutions on settlements. Ultimately, delegates at the plenum passed a toothless document urging Washington and Jerusalem to work out an agreement on the loan guarantees. ${ }^{97}$

The nexus of the argument for the loan guarantees - now the official position of organized Jewry -- was straightforward enough: Israel's needs were humanitarian and should not be held hostage to political concerns. Besides, they argued, the release of Soviet Jews had been a cornerstone of U.S. policy toward the Soviet Union since the 1973 passage of the U.S. Congress's Jackson-Vanik amendment, which made trade with the USSR dependent on its treatment of minorities such as Jews. ${ }^{98}$ Further, they noted, Israel had done the unthinkable during the Gulf War in response to a U.S. request Jerusalem did not strike Iraq after Saddam Hussein's forces hurled dozens of Scud missiles at the Jewish state during the U.S.-led invasion of Kuwait. Revealing the emotion of such a decision, Shamir wrote that he could think "of nothing that went more against my grain as a Jew and as a Zionist... to ask the people of Israel to accept the

\footnotetext{
${ }^{97}$ Ibid, p. 185.

${ }^{98}$ For more on the Jackson-Vanik Amendment see Robert O. Freedman, "Soviet Jewry and SovietAmerican Relations: A Historical Analysis," in Soviet Jewry in the Decisive Decade 1971-89 (Durham, N.C.: Duke University Press, 1984), pp. 44-45.
} 
burden of restraint in the faced of attack." 99 The time for gratitude for such adherence to Washington's wishes, Israel and its American Jewish allies argued, had arrived, and it should be in the form of loan guarantees.

\section{II.8 George H. W. Bush's Strategic Error}

Bush, however, made a strategic error when it came to efforts at persuading American Jews and their allies of his sincerity and to accept his request for a 120-day delay of the formal loan guarantee request. When 1,200 Jewish and other activists blanketed Capital Hill on September 12, 1991 for an "Education Day" to lobby on behalf of loan guarantees, the President held a press conference to counter their efforts. In doing so, he outraged American Jews with comments they believed at best questioned their right to lobby on behalf of Israel, and at worst raised anti-Semitic canards about lurking Jewish power. During remarks in a question and answer session, Bush stated in part:

We're up against very strong and effective ... groups that go up to the Hill. I heard today there were something like a thousand lobbyists on the Hill working the other side of the question. We've got one lonely little guy down here doing it... I don't care if I get one vote, I'm going to stand for what I believe here, and I believe the American people will be with me... 100

To be fair, Bush also made it clear that his comments should not be "viewed as an indication that there exists any question in my mind about the need for a strong and secure Israel." However, that did not register with either American Jews or the antiSemitic segment of the American public. In fact, Shoshana Cardin recalled hearing that

\footnotetext{
${ }^{99}$ Shamir, p. 217.

100 "Excerpts From President Bush's News Session on Israeli Loan Guarantees." New York Times. 13 September 1991.
} 
the White House switchboard was "flooded with phone calls from [white] supremacist groups supporting the statement." 101

A series of conciliatory letters then ensued between the President and Cardin, as well as other American Jewish leaders. The next day, Cardin was measured in her written comments to Bush, in which she first praised his push for Middle East peace. Still, she added, the lobbyists "were exercising their right - even obligation - as American citizens, consistent with democratic process, to advocate their position on this vital humanitarian issue. Thus, she continued, she had found some of the President's comments "disturbing and subject to misinterpretation." 102 One week later, Bush had responded with a letter to Cardin in which he both acknowledged their disagreement regarding loan guarantees and apologized for remarks whose perceived intentions, he wrote, did not reflect his true feelings. He wrote:

My reference to lobbyists and powerful political forces were never meant to be pejorative in any sense. As a veteran of many years in the governmental and political arena, I have a great deal of respect for the exercise of free expression in the democratic process. Politically organized groups and individuals are a legitimate and valued part of the decisionmaking process in a democracy. ${ }^{103}$

Revealing the President's understanding of the need to temper the agitation of Jewish voters, the letter was released to and printed in The New York Times before it even came to Cardin in the mail. ${ }^{104}$

\footnotetext{
${ }^{101}$ Cardin, p. 139-140.

${ }^{102}$ Ibid, p. 141-142.

103 "Bush's Letter To U.S. Jews." New York Times. 21 September 1991. Also see Andrew Rosenthal, "Bush Acts To Calm Israel Aid Uproar.” New York Times. 21 September 1991.

${ }^{104}$ Cardin, p. 143.
} 
Despite that, Israel and its U.S. allies lost the fight and the Congress agreed to the 120-day delay on October 2, 1991. Ironically, this was the second time that AIPAC lost a major fight on Capitol Hill that, by its capturing national headlines along the way, only

seemed to feed into its reputation as a force with which to be reckoned. ${ }^{105}$ Clearly, AIPAC was a political force in Washington, and while a sitting President could defeat the pro-Israel lobby, that would entail a nasty and distracting political fight.

\section{II.9 Baker Outrages American Jews}

Compounding this difficult period of relations between the Bush administration (and hence the Republican Party) and American Jewry even more were comments reportedly made by Baker in early 1992. The Secretary of State, who would soon leave his post to head the campaign to reelect the President, outraged Jewish voters with alleged comments in a White House meeting that touched on Jewish voters' attitudes toward the administration. 'F--- 'em. They [the Jews] didn't vote for us anyway [in the 1988 elections]," Baker said, according to former New York City Mayor and now New York Post columnist Ed Koch while citing anonymous sources. Using strong language, Koch condemned how Bush's and Baker's “continuing assaults on Israel and their constant demands for concessions from Israel without counter concessions from the Arab states fans the flames of anti-Semitism." Further, he wrote, "Jews and supporters of Israel [Koch was both] should not hesitate during the current political debate and election to let

\footnotetext{
${ }^{105}$ In 1981, AIPAC had lost the fight against the Reagan administration's proposed sale of five AWAC-F15 early warning airplane systems to the kingdom of Saudi Arabia in a larger package that also included conformal fuel tanks, AIM-9L Sidewinder missiles and KC-3 aerial tankers. Charles Mohr, "Senate, 52-48, Supports Reagan on AWACS Jet Sale to Saudis; Heavy Lobbying Tips Key Votes." New York Times. 29 October 1981.
} 
the candidates know that the security of Israel is a top priority for them. Other groups advance their priorities without fear of intimidation. Why not supporters of Israel?",106

The column, coming from an influential New York political leader with high standing both nationally and in the Jewish community, not to mention one with a good personal relationship with Bush, caught the President's attention. The President wrote to Koch that he did not "accept that Jim [Baker] would say such a thing" and that Baker was "working relentlessly to find a solution" to the Arab-Israeli conflict. ${ }^{107}$ (Sixteen years later, with the publication of his 2008 book The Koch Papers: My Fight Against AntiSemitism, the former mayor revealed that his source was none other than Secretary of Housing Jack Kemp - also admired as a friend by many American Jews. ${ }^{108}$ )

The damage, however, seemed to be deep amongst a community that potentially might be a swing vote for a Republican candidate in a close race. Bush and the GOP were originally hoping that the U.S.-led battle against Iraq could help them siphon off some Jewish votes from the Democratic Party. As a result, Bush's campaign dutifully sought to better its standing in the Jewish community. In fact, on March 30, 1992 Bush sent a letter to prominent Jewish Republicans in which he stated in part, "our fundamental commitment to Israel is just that - fundamental... I will do all I can to see that the current strains do not grow worse, but on the contrary, are put behind us...” Jewish response,

\footnotetext{
${ }^{106}$ Edward I. Koch, with Rafael Medoff. The Koch Papers: My Fight Against Anti-Semitism. (New York: Palgrave Macmillan, 2008.) pp. 92-94.

${ }^{107}$ Ibid, p. 95.

${ }^{108}$ Ibid, 91. Koch writes in the footnotes to the section that Baker's controversial comments were confirmed within a few days by the New York Post (March 10, 1992) and The Forward (March 13, 1992). pp. 230-231. Mr. Kemp was both taking a political risk in alienating his own party had word gotten out at the time, as well as potentially enhancing his standing with Jewish voters in the run-up to his own anticipated future campaign for the presidency, which took place in 1996.
} 
however, was qualified, as shown by American Jewish Committee executive director David Harris's comment that "deeds are still more significant. We will have to wait and see."109

\section{II.10 Rabin Becomes Prime Minister}

One of the few bright spots for the Bush administration in its courtship of American Jews came with the election of Yitzhak Rabin as Israel's Prime Minister in June 1992. The Israeli officially took office on July 13 that year, having formed a centerleft coalition as opposed to the center-right one of his predecessor. Rabin immediately signified that things would be different in that he would have a negative view toward building settlements and a positive one toward promoting the Middle East peace talks, known as the Madrid process, which had been languishing under Shamir's guidance. ${ }^{110}$ So not surprisingly, when in Jerusalem only six days after Rabin took office, Baker declared that it was "a pleasure to be going to Israel under circumstances in which I anticipate that we will not be met with the opening of a new settlement or settlements, but rather a suspension of contracts for the construction of new houses or settlement activity - something that I can think only inspires trust and confidence."111

\footnotetext{
${ }^{109}$ Grossman, pp. 187-88.

${ }^{110}$ Kenneth Jacobson, "The United States, Israel and the Middle East," in American Jewish Yearbook 1994 (New York and Philadelphia: The American Jewish Committee and The Jewish Publication Society, 1994), p. 161.

${ }^{111}$ Ibid, p. 163. Urged on by Shamir's Housing and Infrastructure Minister, Ariel Sharon, Israeli settlers were told to "grab the hilltops" and set up a new settlement to greet each of Baker's visits to the Jewish state.
} 
The warming of relations set the stage for Rabin's August 10, 1992 meeting with Bush at the latter's summer home in Kennebunkport, Maine. Not only was it portrayed as being held in a relaxed atmosphere, but at the conclusion of the 24-hour visit Bush announced that Israel's much sought after loan guarantees would now be granted to Israel. ${ }^{112}$ Truly signaling a different tone for Israel and to its American supporters, Rabin also agreed at the meeting to tacitly accept the U.S. sale of 72 advanced F-15 aircraft to Saudi Arabia. He did so by shifting the conversation to how the United States could ensure that Israel's qualitative military edge would not be adversely affected. ${ }^{113}$ Likewise, Rabin seemed to telegraph to American Jews his support for the incumbent President in the upcoming national elections. ${ }^{114}$

Such efforts, however, were to no avail for Bush as the $41^{\text {st }}$ U.S. President would be defeated in the November 3, 1992 presidential election. With an overwhelming 80 percent of American Jews having voted for Democratic Party candidate William Jefferson "Bill" Clinton, the GOP outreach effort to Jewish voters had resoundly failed.

Meanwhile American Jews were dealing with a new internal crisis when it came to Jerusalem's new Prime Minister. Shortly after taking office Rabin, known for his gruff persona, had criticized AIPAC for exacerbating tensions with Washington in the way it

\footnotetext{
${ }^{112}$ Ibid, p. 164.

${ }^{113}$ Marvin Feurberger, "Israeli-American Relations in the Second Rabin Era," in Israel Under Rabin. Ed. Robert O. Freedman. (Boulder, Col.: Westview Press, 1995), p. 11.

${ }^{114}$ This was not Rabin's first such statement of indirect support in a U.S. presidential campaign. As Ambassador to the United States, in June 1972 he said of incumbent Republican President Richard M. Nixon, "Never in America's history had any president gone so far in his pro-Israeli declarations or in expressing America's commitment to Israel's security." The remarks set off protest in both Israel and Washington, with the Washington Post publishing a June 15, 1972 editorial entitled "Israel's Undiplomatic Diplomat." Yitzhak Rabin. The Rabin Memoirs. (Berkeley, Calif.: University of California Press, 1996), pp. 232-233.
} 
plowed ahead with the loan guarantees request. As he bluntly told the AIPAC executive board, 'You've aroused too much antagonism, you make too many enemies for yourselves, and your record is poor." ${ }^{115}$ For certain, part of his anger was reflecting the difficulty for American Jews in having to switch from 15 years of Likud rule (including a power-sharing arrangement between Labor and Likud from 1984-1988) to a strong Labor-led government. ${ }^{116}$

The animosity went both ways as some American Jewish leaders did not spare their criticism of Israel's new government. For example, on June 6, 1993 AIPAC Vice President Harvey Friedman, accompanying a congressional delegation, met in Florida with Israeli Deputy Foreign Minister Yossi Beilin. Friedman reportedly told Beilin, "Where does Rabin get the chutzpah to give up territory?" AIPAC director Tom Dine apologized and said that Friedman spoke as an individual and not for the organization. Yet, on July 1 the Washington Jewish Week quoted Friedman as referring to Beilin as "this little slimeball." Friedman was forced to resign from AIPAC and Beilin was loudly lamenting that he and his colleagues had to "justify their desire to make peace.",117

\section{II.11 Intermarriage And A 'Continuity Agenda'}

While American Jewry was beginning to deal with increasing splits on Israel's new path under Rabin, pressing concerns at home would take their attention away from Jerusalem's decisions. This only fed into the worrisome distancing of American Jews

\footnotetext{
${ }^{115}$ Steven T. Rosenthal, Irreconcilable Differences: The Waning Of the American Jewish Love Affair With Israel. (University Press of New England for Brandeis University Press: Hanover, N.H. 2001), p. 121.

${ }^{116}$ Clyde Haberman, "Rabin and Pro-Israel Group Off to Testy Start.” New York Times. 22 August 1991.

${ }^{117}$ Grossman, p. 155.
} 
from both the State of Israel's well-being and Jewish identity itself. If unchecked, the thinking went, the trends could have dire implications for American Jewry as a whole, let alone the power of its pro-Israel advocacy.

Foremost on the minds of Jewish communal planners and leaders was the finding of the 1990 National Jewish Population Study (NJPS), which revealed that 52 percent of new marriages of Jews were to non-Jews. Two decades earlier, the 1970 NJPS found the intermarriage rate to be only 22 percent. ${ }^{118}$ This was combined with the concern of other studies that showed a strong majority of the children in these marriages were not being raised as Jews, which made them less likely to marry non-Jews. In fact, the 1990 NJPS found that 664,000 children were being raised in a mixed household, only 25 percent were being raised as Jews and 45 percent were being raised in another religion. As a result, "most children of mixed marriages will be lost to Judaism.",119

For some American Jewish leaders, there were deep personal dilemmas at stake. The feelings were captured by Charlotte Holstein, chair of the American Jewish Committee's Jewish Communal Affairs Commission. In 1991, as her group was preparing to vote on its controversial policy statement on intermarriage, she noted that her daughter was planning to marry her long-time boyfriend, a Catholic. "I love and respect my daughter and I would do anything to protect her happiness and her future,"

\footnotetext{
${ }^{118}$ The statistics were assailed by Jewish journalist J.J. Goldberg, who said the real number is likely 42 to 44 percent. The error, he said, comes from the complicated "weighting formulas" used by demographers to gain adequate representation of groups that pollsters do not always have equal access to, such as black, poor, rural and Southern Jews. Goldberg found agreement from leading pollster Steven Cohen. He said of the lower mark, "That's still high, but it's not the 'Oh my God, it's more than half' figure that everyone is talking about." Goldberg, pp. 67-68.

${ }^{119}$ Sidney Goldstein, "Insights from the 1990 National Jewish Population Survey," in American Jewish Yearbook 1992. (New York: American Jewish Committee, 1992), p. 127.
} 
she wrote. Nonetheless, she added, she knew she must "draw the distinction between what I felt emotionally and what rationally was good for the survival of the Jewish community as a whole.",120

So it was that in 1991 that her committee passed its Statement on Intermarriage, which was "as lengthy and complex a process as ever took place within the ranks of the AJC.” It took a strong position against intermarriage as weakening Jewish life, but also declared that the Jewish community's challenge was "to offer positive communal and personal connection to the intermarried while at the same time to develop and encourage programs that lead to Jews marrying other Jews."121

That was part of the rise of the "continuity agenda," which became the buzzword of organized Jewish life following the 1991 Council of Jewish Federations General Assembly meeting in Baltimore, Maryland. The gathering is North America's largest annual meeting of Jewish volunteer and professional leaders and its programming focus often both reflects and advances initiatives for the coming year. In 1991, the attention was on recognizing the need to build Jewish identity at home first, which would hopefully forge a Jewish identity that would naturally turn toward concern for Jews overseas.

Examples of the continuity agenda included: a rise in focus on Jewish religious roots, often referred to as "spirituality." This was reflected in the introduction of divrei Torahs, or commentaries on the week's Torah portion, now being given at the start of

\footnotetext{
${ }^{120}$ Marianne R. Sanua, Let Us Prove Strong: The American Jewish Committee 1945-2006. (Waltham, Mass.: Brandeis Univeristy Press, 2007), p. 380.

${ }^{121}$ Ibid, p. 381, citing “AJC 1991 Statement on Intermarriage.” (New York: American Jewish Committee, 1991).
} 
board meetings for Jewish organizations, sometimes by people who rarely studied traditional Jewish text. Likewise, more funding began flowing to Jewish summer camps and to helping children attend them. Modern Hebrew became more common in communal settings, such as calling the "Holocaust" the "Shoah." Adult learning efforts grew, as symbolized by the opening in communities around the country of The Florence Melton Adult Mini-School, which had begun in 1986. They were often hosted by Jewish Community Centers, which were now hiring Jewish education specialists to infuse their operations with Jewish values and learning from the pre-school settings to the senior adult programs.

Groups targeting young adults and teenagers were also energized with funding and focus. A prominent example was the rise of Hillel: The Foundation for Campus Jewish Life, which in 1994 became fully independent from its founder, B'nai B'rith International. Its energetic leader, Richard Joel, became the star of the Jewish communal world, challenging Federation funders and others with talks at venues such as the 1997 UJC General Assembly in which he told activists that they might as well be speaking Klingon - the alien language from the popular Star Trek TV series - when they tried outreach to young adults. ${ }^{122}$ Communities such as Atlanta founded agencies such as Atlanta YAD (Young Adult Agency) to engage both college students and young adults in their 20s, hoping to stoke Jewish loyalties in the years before these young adults would wed and begin families. Likewise, national groups such as the American Jewish Committee and the Anti-Defamation League would join Jewish federations in opening

\footnotetext{
${ }^{122}$ For more on Hillel's meteoric rise, see Jeff Rubin, “The Rise to Renaissance: 1923-2002.” (Washington: Hillel: The Foundation for Campus Jewish Life, 2002).
} 
young leadership groups that would mix social events with the more traditional issueoriented ones of speeches and conferences.

Also, in this period local Jewish communities began putting emphasis on the Jewish day school experience, particularly outside of Orthodoxy, where such attendance was already the norm. So, for example, in places such as Atlanta and Baltimore, Reform Jewish day schools - once anathema to their parent movement, which emphasized unequivocal integration into America -- came into existence. The Conservative movement's Schechter schools grew in number and Jewish summer camps began getting more attention from community leaders and - perhaps most importantly - foundations and individual donors.

\section{$\underline{\text { II.12 Distancing And Dissent On Israel }}$}

Still, concern mounted amongst communal leaders as surveys continued to reveal that the overall attraction to Jewish life by younger Jews showed softening support for the pro-Israel agenda. For example, in 1996, when comparing Americans ages 26-44 to those ages 46-64, Chaim I. Waxman found a growing discrepancy in support for Israel.

Amongst the younger cohort, only about 27 percent said they were either "very attached" or "extremely attached" to Israel. For the older group, however, the number rose to nearly 44 percent. ${ }^{123}$ While not quite as dramatically, the older group was more attached to Jewish life in other ways as well, such as through synagogue and organizational affiliation, and percentage of friends who are Jewish. Describing future implications,

\footnotetext{
${ }^{123}$ Chaim I. Waxman, "Weakening Ties: American Jewish Baby-Boomers and Israel," in Allon Gal, ed. Envisioning Israel: The Changing Ideals and Images of North American Jews. (Wayne State University Press: Detroit, 1996), p. 384.
} 
Waxman wrote that the question was not whether American Jews would continue to be pro-Israel - as most Americans were anyway ${ }^{124}$ - but "the nature and intensity of that support" could suffer. ${ }^{125}$ Steven M. Cohen, perhaps the leading demographer on the issue, found in 1996 both good and bad news on this front. American Jews as a whole, he argued, might be no more distanced from the State of Israel than they were in the previous decade. However, when broken down the numbers for younger Jews - who have more opportunity to visit Israel than counterparts of previous generations -- point to "an impending decline in American Jewish attachment to Israel at some point in the future." ${ }^{\prime 26}$ There were other disturbing general indications. Few could be more telling than a 1993 finding that just after Rabin's forming a government, only 51 percent of all American Jews even knew that he was the Prime Minister of the State of Israel. ${ }^{127}$

Meanwhile, within the pro-Israel community itself dissent was growing when it came to promoting an agreed upon agenda. The battle over what constituted a pro-Israel agenda was not a new one, but until now it had largely been a peripheral one. Indeed, activists in "Israel protest groups" from the 1970s and 1980s - Breira (founded in 1973),

\footnotetext{
${ }^{124}$ American general public opinion strongly favored Israel from 1988 to 2006 when respondents were asked, "In the Middle East are your sympathies more with Israel or with the Arab nations?" The highpoint came in 1991 with the Gulf War as 64 percent said Israel and 8 percent the Arabs. The rest had either no opinion or answered "neither." The low point came in 1996 during tensions with the Netanyahu government. Still, 38 percent favored Israel to 15 percent the Arabs. The complete statistics are at <http://www.gallup.com/poll/22063/Republicans-Religious-Americans-Most-Sympathetic-Israel.aspx >.

${ }^{125}$ Waxman, p. 392.

${ }^{126}$ Steven M. Cohen, "Did American Jews Really Grow More Distanced from Israel, 1983-1993? - A Reconsideration," in Allon Gal, ed. Envisioning Israel: The Changing Ideals and Images of North American Jews. (Wayne State University Press: Detroit, 1996), p.368.

${ }^{127}$ Rosenthal, p. 124, citing Jerusalem Post, 1 July 1993. This was even more shocking when one considers that Rabin, having served as Israeli Ambassador to the United States from 1968-1974, and then Prime Minister from 1974-1977, was a name presumably known to much of American Jewry.
} 
the New Jewish Agenda (founded in 1979), the New Israel Fund (founded in 1979), and Americans for Peace Now (founded 1981, three years after its Israeli counterpart) - had primarily been seen more as constituting an interesting subset of organized Jewish life than in a position to influence the mainstream. They did, however, jolt the discussion over new definitions of pluralism and acceptable dissent from American Jews when it came to Israel. $^{128}$

A prime motivator of such dissent was the 1977 election of Likud leader Menachem Begin, who immediately began putting resources into making Jewish settlement on the West Bank, Gaza Strip and Golan Heights (all taken by the IDF in the 1967 Six-Day War) a major policy. While the Labor governments of the 1970s had permitted some of these communities to spring up, those venues were relatively small and residence was not induced by government subsidies. ${ }^{129}$ Begin and his colleagues immediately set about to change that through their support of the Gush Emunim (Block of the Faithful) settlers group. ${ }^{130}$

Until this period, major American Jewish organizations had generally adhered to the practice of advocating the policies of Israel's government, which they saw as an extension of the desires of the majority of Israel's citizens. Begin did, however, find surprise support from some quarters. In the late 1970s, then chairman of the President's

\footnotetext{
${ }^{128}$ For a more detailed history of these groups and the controversies they caused in American Jewish life, see Jack Wertheimer, "Breaking the Taboo: Critics of Israel and the American Jewish Establishment," in Allon Gal, ed., Envisioning Israel (Detroit: Wayne State University Press, 1996), pp. 397-408.

${ }^{129}$ To understand how the inner dynamics of Labor Party politics between Rabin and Peres were a factor in Labor support for settlements, particularly Sebastia, see Michael Bar-Zohar, Shimon Peres: The Biography. (New York: Random House, 2007), pp. 306-311.

${ }^{130}$ Ian Lustick, For the Land and the Lord: Jewish Fundamentalism in Israel. (New York: Council on Foreign Relations), pp. 46-71.
} 
Conference, Rabbi Alexander Schindler - a staunch ally of Israel's dovish Labor Party, famously embraced the new prime minister. As Schindler told one reporter, "Dissent ought not and should not be made public because ... when Jewish dissent is made public in the daily press or in the halls of government, the result is to give aid and comfort to the enemy and to weaken that Jewish unity which is essential for the security of Israel."131

It would be difficult, however, to increasingly tow that line as American Jews kept creating and funding groups that disagreed with Jerusalem's policies. The issue came to a fore in early 1993 when Americans for Peace Now applied for membership to the President's Conference. Here was a group that openly criticized settlements and called for dialogue with the Palestine Liberation Organization, an organization still formally at war with the State of Israel. Groups on the right - such as the Zionist Organization of America - vehemently opposed the inclusion. However, the American Jewish community was confronted with a stark reality: How could it not allow in such a group if first that body reflected the desires of the Rabin government ${ }^{132}$ and second the group had some prominent supporters tapped for high positions in the Clinton administration? ${ }^{133}$ So it was that on March 29, 1993 the President's Conference, by a vote of 27 to 10 with eight abstentions, welcomed APN into its ranks. ${ }^{134}$ For the first time, an

\footnotetext{
${ }^{131}$ Sol Stern, “Menachem Begin vs. the Jewish Lobby.” New York Magazine. 24 April 1978, p. 62.

${ }^{132}$ Americans for Peace Now's stands were largely in line with those of Israel's Meretz Party, which with 10 seats was a key coalition party in the Rabin government.

${ }^{133}$ Wertheimer, "Breaking The Taboo," p. 417, citing David Twersky, "Welcome to Washington Now, Peace Now," Forward, 19 February 1993.

${ }^{134}$ Grossman, "Jewish Communal Affairs.” American Jewish Yearbook 1995. (New York and Philadelphia: The American Jewish Committee and The Jewish Publication Society, 1995), p. 152.
} 
American Jewish group that supported "land for peace" was part of the community's most influential body.

\section{II.13 Rising Religious Politics}

In a more subtle way, the strengthening of American Jewry's congregational arms during these years also led to a breakdown in American Jewish unity in publicly approaching Israel's policies. Synagogue-related organizations were a rising political force in Washington, D.C. Despite the traditional pro-Israel agenda of other groups, the majority of lobbying by religious groups was on domestic issues -- religion and state, education voucher programs, social action, religious freedom issues, etc. Israel policies, however, were soon to be part of the mix.

By the early 1990s nearly every major synagogue group had established a presence in Washington, D.C., to lobby on behalf of their organization's positions. This both increased the number of Jewish professionals lobbying in the nation's capital on Jewish issues and increased the likelihood of different positions emanating from groups saying they spoke from a religious perspective on behalf of American Jews.

The Reform movement was the most experienced when it came to the ways of Washington, having established its Religious Action Center for Reform Judaism in 1959. Meanwhile, Agudath Israel, an ultra-Orthodox group, opened its Washington office in 1988. ${ }^{135}$ The organization is an international one. In Israel it has a political party of the

\footnotetext{
${ }^{135}$ For a look at Agudath Israel's priorities during these years, see "Agudath Israel of America National Public Policy Position Paper," 29 June 1999. Jewish Law. <http://www.jlaw.com/LawPolicy/OU1.html>. This journal is only published on the Internet and does not have issue dates. Rather, it posts papers as they become available. The Agudath Israel paper takes generic stands such as pointing out that "treating Israel
} 
same name, which is often a partner in the government coalition with other Haredi groups in the Knesset. Thus, Agudath's Washington office logically espoused positions paralleled by those coming from its politicians in Jerusalem.

Not to be outdone, the "modern" or "centrist" Orthodox group, the Orthodox Union, opened a Public Affairs office in Washington in 1990. The OU's Public Affairs offices had already been in operation in the organization's New York City headquarters for several years, but recognized the need to be part of the lobbying scene in the nation's capital were its voiced to be heard. ${ }^{136}$

Only the Conservative movement did not have a Washington operation, despite some talk amongst the leadership that it needed just that. ${ }^{137}$ Conservative Judaism did have an official American Zionist operation, called Mercaz (which means "center" in Hebrew). However, Mercaz had a low profile and the movement traditionally worked to strengthen its congregations, Ramah camps, and its main university, the Jewish Theological Seminary of America, more than anything else.

\section{II.14 A Holocaust Agenda Achieved}

Beyond the pro-Israel agenda, until the advent of the Oslo years, American Jewry had focused on the campaign to free Soviet Jews. That was part of an overall strategy in

as the ally it in fact is indeed, the only truly reliable ally the free world has in the Middle East, is a policy that has reaped and will continue to reap substantial benefits for the United States."

${ }^{136}$ For the development of the OU's Institute for Public Affairs, and its move to Washington, D.C. from New York City, see Granchow, Mendy. Journey Through The Minefields: From Vietnam to Washington: An Unorthodox Surgeon's Journey. (Silver Spring, Md.: Eshel Books, 2004), pp. 159-160, 169.

${ }^{137}$ Rabbi Seymour Essrog, who served as the president of the Conservative movement's Rabbinical Assembly movement during the late 1990s, and I held several conversations on the topic. 
which American Jews would simply speak out on anything that they felt threatened their agenda. There is no doubt that one strong reason behind such activism was the permanently lingering shadow of helplessness felt by American Jews during the Second World War regarding their perceived failure to rescue European Jewry from the Nazis.

As Michael Berenbaum has written in describing the sense of empowerment that American Jewry felt by the start of the 1990s:

Ours is the first generation to stand at a distance from the Holocaust and the last to live in the presence of the survivors... The American Jewish community is a potent political force, able with the help of allies to achieve its political goals: to support candidates helpful to Israel and defeat those who are not; to convince the Congress and successive administrations that aid to Israel is in the vital national interest; and to encourage special efforts on behalf of oppressed Jews in the Soviet Union, Iran or Ethiopia. This achievement of power is silhouetted against the background of powerlessness and defeat of but one generation ago. ${ }^{138}$

With that in mind, it is not surprising that for many, a cause equally as critical as that of Soviet Jewry was making Holocaust education and awareness a permanent part of the American educational landscape. The effort had received a jolt forward in 1979 when President Jimmy Carter created the President's Commission on the Holocaust. That led to Carter's Executive Order 12903, which created a week-long national commemoration to coincide with Yom HaShoah - the Jewish community's Hebrew name for Holocaust Memorial Day. ${ }^{139}$ The President's Commission on the Holocaust itself led to the recommendation to create a U.S. Holocaust Memorial Museum in Washington, D.C. So on April 22, 1993, the $\$ 168$ million structure - mostly funded privately but governed by

\footnotetext{
${ }^{138}$ Michael Berenbaum, After Tragedy and Triumph: Modern Jewish Thought and the American Experience. (Cambridge: Cambridge University Press, 1990), p. 164.

${ }^{139}$ Ibid, pp. 33-42.
} 
federal laws -- opened in a well-publicized ceremony attended by most U.S. government leaders, including President Bill Clinton, Israeli President Chaim Herzog and Nobel Peace Prize Laureate and Holocaust survivor Elie Wiesel. ${ }^{140}$

By now, throughout the country Holocaust awareness had become a staple of American public discourse. Jewish communities across the country raised funds for local Holocaust memorials, which were the site of annual observances well-attended by politicians and communal leaders. In addition, countless public school systems introduced Holocaust education into their world history units during discussions of the Second World War. Civic organizations and local governments often held ceremonies featuring talks by Holocaust survivors and their G.I. liberators.

Enhancing this trend is that Hollywood, America's great purveyor of popular culture, caught on as well. In 1993, the acclaimed director Steven Spielberg made the film "Schindler's List," an emotionally grueling three hour and 15 minute portrayal of Nazi occupation and enslavement of Jews. It was hailed as one of the more important films ever made, and duly was nominated for 12 Academy Awards, walking away with seven of them. This "must see" film in turn spawned an industry of other high budget, star-packed Holocaust related theater and television films in the coming years such as "Jakob The Liar" and "The Holocaust: In Memory of Millions" (hosted by venerated TV news anchor Walter Cronkite).

Thus, as with the Soviet Jewry campaign, by the advent of the Oslo years, one of U.S. Jewry's core goals - institutionalizing commemoration of the Holocaust - was a

\footnotetext{
${ }^{140}$ Diana Jean Schemo, "Holocaust Museum Hailed As Sacred Debt to Dead." New York Times. 23 April 1993.
} 
success. ${ }^{141}$ That left pro-Israel advocacy as the last great shared goal of American Jewry.

The emotional debates over the Oslo Accords, however, would see battles simmering

below the surface of American Jewish life - particularly amongst various religious camps

- became a dominant factor in American Jewish life.

\footnotetext{
${ }^{141}$ This is not meant to suggest that many core activists on Holocaust and Soviet Jewry issues felt their job was done. Indeed, they took up new directions, such as ensuring that Holocaust programs would continue to be funded and oral testimonies collected. When it came to the former Soviet Jews, there was as much passion directed toward helping immigrants settle in Israel as there was in building Jewish communities and life for those who stayed put.
} 


\section{Chapter III. The Rabin-Peres Years}

\section{III.1 How Washington Became Israel's Top Ally}

If there was one thing successive U.S. administrations could agree on from 1967

until 1993, it was that progress on the Arab-Israeli front was slow, painful and at best incremental. Until the immediate aftermath of the June 1967 War, the United States had not played a major role in either being Israel's top defender on the world stage ${ }^{142}$ or pushing Israel forward into a peace process. That all changed in both the lead up to and the aftermath of the war. The conflict suddenly created a dramatically changed ArabIsraeli front, one that brought both new opportunities and fresh obstacles to the search for a lasting end of hostilities and normalization of relations between Israel and its Arab neighbors. That is because the map figuratively and literally changed from June 5-11, 1967 as the Israel Defense Forces swiftly humiliated the numerically overwhelming Egyptian, Jordanian and Syrian armies. ${ }^{143}$ The five major changes brought about by the war were:

1) Geographic: Israel now controlled the Gaza Strip, the launching pad of Palestinian terrorist raids since the end of the 1948-49 War of Independence; the Golan Heights, the base of Syrian shelling on Israeli northern settlements and the home of important regional water sources; the West Bank (including East Jerusalem and its Old City), the physical cradle of the Jewish biblical narrative; and Egypt's expansive Sinai peninsula, offering a broad land cushion between Israel and Egypt.

\footnotetext{
${ }^{142}$ In fact, the Eisenhower administration (1953-1961) in 1956 threatened to cut off all American economic aid to Israel to force Israeli withdrawal from lands captured in the 1956 Sinai campaign. Steven T. Rosenthal. Irreconcilable Differences: The Waning Of the American Jewish Love Affair With Israel. (University Press of New England for Brandeis University Press: Hanover, N.H. 2001), p. 28.

${ }^{143}$ See Michael Oren, Six Days of War: June 1967 and the Making of the Modern Middle East. (Oxford University Press: Oxford, England, 2002). Oren wrote at the end of his exhaustive study that as a result of the war, "Events in the region that previously converged only toward conflict, could also, post-1967, surge in the direction of peace," but the war also "opened the door to even deadlier conflicts." Oren, p. 327.
} 
2) Demographic: Israel now controlled 1 million Palestinians in the newly acquired territories (in addition to the roughly 20 percent of its citizens who were Israeli Arabs). As a result, it was no longer seen by others as a besieged nation; it was now a regional military power responsible for a large population under military occupation, which in turn made that population increasingly dependent on Israel's economic and political policies.

3) Domestic Political Debates: Israeli Jews were basically divided into two camps. One believed that the captured lands brought a tremendous bargaining chip for peace, ${ }^{144}$ the other that the Jewish people had been rightfully restored by God as the rulers of land that could never be voluntarily relinquished. ${ }^{145}$ This clash of visions reflected an increasingly sharpening Israeli political debate ever since and featured prominently in the 1995 Rabin assassination.

4) Diplomatic: The United States supplanted France as Israel's top military and diplomatic patron. The relationship - spurred in part by the Cold War (Israel was a staunch U.S. ally and most Arab states were Soviet patrons, Jordan being a notable exception) -- grew so close so quickly that only six years later, one week into the 1973 October/Yom Kippur War, U.S. President Richard M. Nixon authorized a massive U.S. resupply of the Jewish state with 22,000 tons of equipment on 566 military flights to replenish Israel's rapidly diminishing stocks of war materials. ${ }^{146}$

5) Energizing of Diaspora Jews: Jews around the world surged with Zionist pride, particularly in the Soviet Union (which sparked the Soviet aliyah and refusenik movements). In the United States, Jews, many of whom before the war were ambivalent about Israel's fate, became increasingly committed to its well-being. Indeed, advocating on behalf of the Jewish state quickly became the top item on U.S. Jewry's advocacy agenda.

\footnotetext{
${ }^{144}$ Indeed, this was the official position of Israel's government. The Israeli cabinet on June 19, 1967 voted that it would return to the pre-war borders with Egypt and Syria in return for "peace and demilitarization." While the government had already annexed East Jerusalem and expanded the city's borders, it added that the West Bank would be subject to negotiations. William Quandt, Peace Process: American Diplomacy and the Arab-Israeli Conflict Since 1967. $3^{\text {rd }}$ ed. (Washington, D.C., and Berkeley, CA: Brookings Institution Press and University of California Press, 2005), pp. 44-45.

145 Ravitzky, Aviezer. Messianism, Zionism, and Jewish Religious Radicalism. (Chicago: The University of Chicago Press, 1993), pp. 123-144. Ravitzky contrasts the philosophical approach of Rabbi Avraham Yitzhak HaCohen Kook (1865-1935) on the theological sacredness of the land to that of his son, Rabbi Zvi Yehuda Kook (1891-1982), who translated such emotions into political action to reject any geographic concession to the Arab states. The younger Kook was the spiritual/ideological mentor of the Gush Emunim (Bloc of the Faithtful) movement, which spearheaded the Israeli West Bank/Gaza settlement movement.

${ }^{146}$ Sachar, Howard M. A History of Israel: From the Rise of Zionism to Our Time. $3^{\text {rd }}$ ed. (New York: Knopf, 2007), pp. 769-770. Also see Kissinger, pp. 507-515.
} 
Meanwhile, the U.S. government increasingly became seen as the only country able to both bring Israel into a peace process as well as protect the Jewish State's interests. In fact, between 1967 and 1993, almost every major effort at Israeli-Arab peace making was initiated by high level U.S. involvement. The Oslo Accords would - at least in their formation - be a notable break in this pattern.

Following the Six-Day War, Washington took the lead by protecting Israel at international forums, particularly at the United Nations. After a few failed U.S. efforts, such as the 1969 Rogers Plan, the peace push gained major attention in the aftermath of the 1973 October or Yom Kippur War. In that conflict, Israeli troops were surprised by Egyptian and Syrian forces, only to eventually regain the upper hand. In its aftermath, U.S. Secretary of State Henry Kissinger spent exhaustive months engaged in what became known as "shuttle diplomacy," flying from Jerusalem to Cairo to Damascus and to various other regional capitals as he maneuvered the complicated pieces of the Middle East chess board in favor of disengagement accords. Ultimately, Kissinger negotiated two such accords between Israel and Egypt, and one between Israel and Syria. ${ }^{147}$

\footnotetext{
147 For the Rogers Plan, see William Quandt, Peace Process: American Diplomacy and the Arab-Israeli Conflict Since 1967. $3^{\text {rd }}$ ed. (Washington, D.C., and Berkeley, CA: Brookings Institution Press and University of California Press, 2005), pp. 67-70. The plan, named for U.S. Secretary of State William Rogers, called in part for a return to "the former international boundary between Egypt and the mandated territory of Palestine" to become "the secure and recognized boundary between" Israel and the Egypt. With adjustments, it basically became the foundation of future proposals meant to end the state of war.
}

For Kissinger's mission, see Henry Kissinger, Years Of Upheaval. (Boston: Little, Brown and Company, 1982), pp. 799-853, 935-978, 1,032-1,110. 
Next was President Jimmy Carter's (1977-1981) personal effort to force an Egyptian-Israeli peace treaty, which came to fruition in $1979 .{ }^{148}$ It not only set an example of extended presidential involvement, but created the first major paradigm shift for American Jews. They, and the rest of the world, began thinking that peace between Israelis and Arabs might become a reality. This even led to the establishment of some American Jewish advocacy groups who were more liberal than the mainstream ones. ${ }^{149}$

President Ronald Reagan (1981-1989), the next U.S. President to lend his name to Arab-Israeli peace efforts, announced on September 1, 1982 the "Reagan Plan." For the first time the U.S. government formalized U.S. opposition to both Israeli annexation of the West Bank ${ }^{150}$ and to an independent Palestinian state. ${ }^{151}$ Meanwhile, Israel's 1982 Lebanon War also brought new strains with Washington. While the U.S. criticized Israel's heavy bombing of Beirut and its surrounding area, tensions rose higher after the murder by Lebanese Christian Phalange forces of hundreds of Palestinians at the Sabra and Shatilla Palestinian refugee camps. The attacks were seen as revenge for the

\footnotetext{
${ }^{148}$ It is worth noting that this initiative began not at U.S. urging, but with the surprise visit of Egyptian President Anwar el-Sadat to Jerusalem in November 1977 where he addressed the Israeli Knesset. However, without the intervention of Carter and his team, it is difficult to imagine that a peace treaty would have developed. With the Oslo Accords, the two sides first agreed on a pact and then sought U.S. support.

${ }^{149}$ Jack Wertheimer, "Breaking the Taboo: Critics of Israel and the American Jewish Establishment," ed. Allon Gal, ed. Envisioning Israel (Jerusalem: Magnes Press; Detroit: Wayne State University Press, 1996), 397-408. Wertheimer details the rise of Breira, the New Jewish Agenda, the New Israel Fund, and Americans for Peace Now.

${ }^{150}$ The Israeli government in 1981 had created a de facto annexation of the Golan Heights by lifting military rule in that region and replacing it with Israeli civilian rule. Technically, by this action Israel could claim that it did not formally annex the Heights. David K. Shipler, "The Golan Heights Annexed By Israel In An Abrupt Move." New York Times, 15 December 1981.

${ }^{151}$ Reagan said he favored an association between Gaza, the West Bank and Jordan. Interestingly, Egypt had formerly controlled Gaza. Also, one should remember that Reagan's speech was made as Israel wound down the major fighting of the First Lebanon War, which was seen as weakening the PLO and thus creating an opportunity for negotiations. By then, Israeli troops controlled Southern Lebanon up to the edge of Beirut. Quandt, pp. 254-256.
} 
assassination of the country's pro-Israel president, Bashir Gemayel, but Israel - whose forces controlled the area - was seen by most of the international community as responsible for permitting the massacres on its watch.

Amongst Israel's backers in the United States, the resulting protests created the second major paradigm shift. This one saw the legitimization of massive public protest against the State of Israel's policies by Israeli Jews and their American sympathizers. In fact, an estimated 400,000 Israelis - almost one in ten people in the state - came out at one event alone to publicly criticize their government. ${ }^{152}$

One more major push by the Reagan administration came in 1988 with the U.S. decision to begin low-level conversations with the Palestine Liberation Organization. This occurred after PLO leader Yassir Arafat - after much U.S. pressure -- finally issued a statement that satisfied U.S. insistence that he recognize Israel's right to exist, favor a two-state solution to the conflict and reject terrorism as a tool to attain political goals. ${ }^{153}$ The U.S.-P.L.O. dialogue, which took place in Tunis, Tunisia, ended in 1990 when a renegade PLO faction (which rejected the dialogue with the United States) launched a failed attacked on Tel Aviv beach and Arafat refused to criticize the action or sanction those responsible.

The next major episode in U.S.-Israeli relations came during the administration of President George H.W. Bush (1989-1993). This was during the lead up to and prosecution of the 1991 Gulf War, which pitted a U.S.-coordinated international coalition

\footnotetext{
${ }^{152}$ The demonstration led to pressure for Prime Minister Menachem Begin to create a Commission of Inquiry, which brought even more self-criticism from Israelis and their American allies about the Israeli government's prosecution of the First Lebanon War. David K. Shipler, "Begin Agrees To Establish A Panel To Investigate The Beirut Massacre." New York Times. 29 September 1982.

${ }^{153}$ Quandt, pp. 277-285.
} 
against Saddam Hussein's Iraq, which had invaded and annexed oil-rich neighboring Kuwait. For the first time, the U.S. coaxed Arab nations such as Egypt, Syria and Saudi Arabia into a coalition that would attack a fellow Arab state. Israel, while an undeniable regional military power and a close U.S. ally, was formally left out of the effort. Washington and Jerusalem policymakers knew that the Jewish state's inclusion could negate the participation of Arab states, particularly Syria, which was still officially at war with Israel. Saddam Hussein knew this, too. Seeking to weaken the U.S.-led forces and rally the Arab masses to his side, his troops hurled 39 SCUD missiles toward Israel. The weapons, however, resulted in more hysteria than deaths due to Israeli fears of chemical warheads. Israel grudgingly restrained from responding. ${ }^{154}$

This was not only the first time the Jewish state did not quickly retaliate against a direct attack, but it did starkly reveal its junior status in its alliance with Washington. Still, to help restrain Israel, the U.S. brought Patriot anti-missile batteries staffed by U.S. soldiers to Israel's shores. The welcoming of foreign forces engaged in combat onto its soil also was a first in modern Israel's history.

In the aftermath of the Gulf War, U.S. Secretary of State James Baker set out to forge what would become the Madrid Peace Conference, the first face-to-face negotiations between leaders of Israel and its Arab neighbors since the Israel Independence War 1949 Rhodes Armistice Agreements. ${ }^{155}$ The multi-lateral Madrid Process was proceeding sluggishly by August 1993 when the third great paradigm shift

\footnotetext{
${ }^{154}$ Yitzhak Shamir. Summing Up: An Autobiography. (Diane Publishing Co.: Darby, Pa., 1994), pp. 223225. Shamir informed Washington that were Iraqi missiles hitting Israel equipped with chemical warheads "we would intervene at once."

${ }^{155}$ It's important to note that the Rhodes talks brought not peace treaties, but formal cessation of hostilities pacts.
} 
for U.S. Jewry rocked its pro-Israel agenda: With the Oslo Accord, for the first time Israel and an Arab neighbor achieved a major breakthrough without U.S. guidance.

\section{III.2 The Rabin-Clinton Bond}

When Gov. Bill Clinton defeated incumbent President George H.W. Bush in the 1992 U.S. presidential elections, no one predicted that a Mideast peace effort would become the signature foreign affairs event of his presidency. After all, the Governor of Arkansas not only personally had no policy experience in overseas diplomacy, but he had made economic recovery and domestic social issues such as health care reform and gays in the military major foci of his campaign. He did, however, offer the requisite words for any serious presidential candidate on Israel. He called the Jewish state "our strongest democratic ally in the Middle East" and was critical of the Bush administration's "onesided pressure on our democratic ally Israel." ${ }^{\prime 156}$ Still, the Clinton administration once in office was initially more concerned with the ethnic strife ripping apart the Balkans than the Arab-Israeli conflict. ${ }^{157}$

Besides, if personal chemistry was important in peacemaking, it was hard to imagine political figures more opposite than Bill Clinton and Yitzhak Rabin. The Israeli’s experience clearly dwarfed the American's when it came to politics, international relations and military affairs. Since the mid-1940s, Rabin had been a figure in nearly all of his country's military and foreign issues. By the time he had became the Jewish state's

\footnotetext{
${ }^{156}$ George Gruen, "Jewish Attitudes Toward Israel: Continued Support in the Face of Dramatic Change," Israel Under Rabin, ed. Robert O. Freedman (Boulder, San Francisco, Oxford: Westview Press, 1995), pp. 53-54.

${ }^{157}$ Quandt, p. 324.
} 
top elected leader in 1992, his previous titles had included: Israel Defense Forces Chief of Staff (1964-1968); Ambassador to the United States (1968-1972); Prime Minister (1974-1977); and Defense Minister (1984-1990). As such, he was a known entity in Washington, D.C. and could count leading political figures such as Henry Kissinger and philanthropists such as Abe Pollin as personal friends. By contrast, Clinton had been Governor of Arkansas from 1978-1980 and then from 1982-1992, but had no practical military or international affairs experience (a major issue raised by Bush supporters, albeit unsuccessfully, during the 1992 campaign).

Yet, in sharp contrast to the Israeli leader, the U.S. politician was gregarious, had a winning way with almost everyone and thrived in the public spotlight. Finally, their age difference - at the 1993 Oslo signing Rabin was 71 and Clinton was 46 -gave them different world views. The former's was shaped by the devastation wrought upon the Jewish people during World War II, which reinforced his Labor Zionist vision for an independent, militarily strong Jewish state. The latter's perspective was shaped by the 1960s protest generation regarding America's role in the Vietnam War as well as the Civil Rights movement. In short, the distance in the public profiles of the two seemed, just like Washington and Jerusalem, on different sides of a vast ocean.

Nonetheless, the two seemed to bond relatively quickly, much in the way an elder father figure takes a younger protégée under his wing. The powerful role Rabin played in the life of Clinton was captured by Steven Grossman when the latter was chairman of the Democratic Party. As an overnight guest in the White House, on April 1995, Clinton and Grossman were standing outside the Yellow Oval Room on the second floor at 2 a.m. The President pointed out to Grossman four gifts presented to him from the Israeli- 
Jordanian peace treaty signing the previous fall. One was from Leah and Yitzhak Rabin: a tray engraved with a Psalm. Clinton, Grossman related, "looked at the tray and said of Rabin, 'I admire that man, a great man, a hero. I so, so admire him.' I mean, it was two in the morning. There were no reporters there. He didn't have to say anything." ${ }^{158}$ Clinton himself writes in his memoirs, "By the time [Rabin] was killed, I had come to love him as I had rarely loved another man."159

Indeed, American foreign policy leaders from both the Democratic and

Republican camps alike trusted Rabin as a man of deep experience and, most of all, unquestionable integrity. ${ }^{160}$ His word - unlike that of the unpredictable and always shifting Yassir Arafat - could be trusted and he could show flexibility in understanding the needs of the Palestinian leadership. ${ }^{161}$

In general terms, Clinton seemed to embrace not just Rabin, but anything having to do with Judaism and the State of Israel. The President himself said his love for the Jewish state stemmed from his childhood preacher, who had a passionate attraction to the

\footnotetext{
${ }^{158}$ Netty C. Gross. “The Kinship.” The Jerusalem Report, 25 May 1998, p. 30.

${ }^{159}$ Bill Clinton. My Life. (New York: Random House, 2004), p. 679.

${ }^{160}$ While much has been written about the Rabin-Clinton bond, the brief-tenure of the Rabin-Bush administration ties were also warm. As the GOP's James Baker, III said just after Rabin's assassination, recalling how when in private together Rabin would drink Scotch-on-the-rocks as Baker would have chilled vodkas. "I loved this guy, I mean I really loved this guy." One cannot remotely envision a similar relationship with Arafat and U.S. officials. Elaine Sciolino, "Assassination in Israel: Washington; American Officials Warmly Remember Rabin As A Friend They Came To Trust Deeply." New York Times. 6 November 1995. For a critical view of how the Rabin-Clinton close relationship damaged the Oslo process, see Aaron David Miller, The Much Too Promised Land. (New York: Bantom Books, 2009), pp. 249-253. Miller writes,"None of us ever gave much thought to challenging the prime minister. Clinton was a quick study on the Middle East, but what did he, or any of us, know about matters relating to peace and war?" p. 252.

${ }^{161}$ Barry Rubin and Judith Colp Rubin, Yasir Arafat: A Political Biography. (Oxford, England: Oxford University Press, 2003), pp. 154-155. The authors, in this highly critical book on Arafat, quote Shin Bet head Carmi Gillon as saying about Arafat, "He cheated us a lot."
} 
State of Israel. After Clinton was defeated in his first reelection bid for Governor, the religious leader told him that he would some day become president - and then warned him that God would never forgive him were he to betray the State of Israel. ${ }^{162}$

Finally, to many American Jews, it was not just Rabin or Israel that Clinton - a Southern Baptist -- seemed so enamored with, but Jews themselves. As the Jerusalem Report's Netty C. Gross noted in a 1995 article on the topic:

"He has close friendships with many Jews; regularly delivers emotional, Scriptural-studded speeches to Jewish audiences; beamingly lights Hannukah candles in the White House; and has made three trips to Israel as president...; went jogging in an 'I met [Israeli cancer-stricken teen] Yoni Dotan' T-Shirt; [and] is said to particularly cherish Hebrewengraved gifts given to him by Jewish friends."163

Such sentiments were handsomely rewarded, as noted, in electoral support for Clinton by American Jews in 1992, 1996 and then in the 2000 presidential elections to Clinton's anointed successor, Vice President Al Gore.

\section{III.3 Rabin's Rocky Relationship With American Jews}

While Rabin and Clinton cemented their bond of friendship, the same could not be said of the Israeli and much of American Jewish leadership. In fact, when Rabin came into the office, still during the Bush administration, he seemed to garner more praise from the White House than from American Jewry. The former relaxed in no longer having to confront a combative and seemingly unbendable Yitzhak Shamir, but the latter were

\footnotetext{
${ }^{162}$ Gruen, "Jewish Attitudes Toward Israel: Continued Support in the Face of Dramatic Change," p. 54.

${ }^{163}$ Gross, p. 30.
} 
literally berated by Israel's prime minister, a behavior repeated periodically during the next three years.

Shortly after forming a government, Rabin came to the United States to see Bush. On that trip, he met with AIPAC's top staff and delivered a "blistering dressing down." He did so because of his anger over how the American lobbyists backed the Shamir government -- aggravating the Bush White House -- regarding settlement growth. That in turn held up the $\$ 10$ billion loan guarantees to settle former Soviet Jews in the Jewish state. Unlike Shamir, Rabin was scaling back West Bank settlement building in exchange for the guarantees. AIPAC, Rabin said, "had done more harm than good, waging battles 'that were lost in advance."' For good measure, he added that American Jews had no right to pursue their own policy initiatives and should instead "take instructions from the Israeli Embassy in Washington."

Then, while publicly meeting with members of the President's Conference, Rabin repeated similar comments. "Those who heard him at the public meeting were taken aback both by his angry tone and his insistence that Israel would make its own policy and convey it directly to the U.S. government."165 In other words, Rabin was telling American Jews to keep out of Israel's business. No doubt told by advisers to soften the blows, Rabin spoke via satellite on September 7, 1992 to the B'nai B'rith International

\footnotetext{
${ }^{164}$ Clyde Haberman. "Rabin and Pro-Israel Group Off to Testy Start." 22 August 1992. New York Times. Despite his tenure as Israeli ambassador to the United States, this episode revealed a surprising failure to understand the U.S. system. Were AIPAC to "take instructions" from the Israeli embassy, it would have to register as a foreign agent, thus losing clout regarding the claim that it represented the best interests of the American public.

${ }^{165}$ Lawrence Grossman, “Jewish Communal Affairs.” American Jewish Yearbook 1994 (New York and Philadelphia: The American Jewish Committee and The Jewish Publication Society, 1994), p. 189. Haberman, "Rabin and Pro-Israel Group Off to Testy Start.” New York Times. 22 August 1992.
} 
convention. In his talk Rabin said he was only upset with "one organization," which obviously meant AIPAC, and that he admired "the devotion" of the American Jewish community to Israel. ${ }^{166}$

After the Oslo signing itself, Rabin remained concerned that some American Jewish leaders were too close to Likud policies. So he reportedly called for the resignation of leaders at AIPAC and the President's Conference. The idea was immediately rejected by all mainstream American Jewish organizations, ${ }^{167}$ no doubt scoffing at the idea that a foreign head of state - even Rabin - could pick their top strategists.

Also, only hours after he signed the Oslo II Interim Agreement in Washington, D.C., on September 24, 1995, Rabin met privately with U.S. Jewish lobbyists and harshly addressed them for their lack of financial and political support for Israel. His remarks were generally received well as it was understood that he was targeting groups such as the right-wing Zionist Organization of America and several Orthodox groups. The ZOA and the others had lobbied against the U.S. government's policy - favored by Rabin - of providing the Palestinian Authority with $\$ 500$ million in U.S. aid and loan guarantees for five years. ${ }^{168}$ Yet, it is telling that Rabin made the remarks to the largely mainstream Conference of President's group, of which ZOA was a member.

\footnotetext{
${ }^{166}$ Ibid, p. 189.

${ }^{167}$ Martin J. Raffel, "History of Israel Advocacy," Jewish Polity and American Civil Society: Communal Agencies and Religious Movements in the American Public Sphere. eds. Alan Mittleman, Jonathan D Sarna and Robert Licht. (Lanham, Md. And Oxford, England: Rowman \& Littlefield, 2002), p. 153.

${ }^{168}$ Alison Mitchel, "Rabin Rebukes U.S. Jewish Groups On Lobbying,” New York Times, 30 September 1995. Rabin, in fact, was lobbying the U.S. Jewish community to stop its bickering over congressional aid to the Palestinian Authority.
} 
In retrospect, none of this should have been surprising. Acquiescing in American

Jewry's desire to be integral to U.S.-Israeli ties and American politeness was not in

Rabin's composition. Further, despite his diplomatic background in Washington, D.C., no

one ever mistook him for being a schmoozer. As Clyde Haberman of the New York Times

put it, he could deliver his displeasure with "characteristic gruffness and looks that could

freeze mercury." ${ }^{169}$ Likewise, in Rabin's 1979 biography The Rabin Memoirs, one sees

uncensored directness ranging from navigating his occasionally tense relationship with

Henry Kissinger to his legendary political rivalry with fellow Labor Party leader Shimon

Peres. $^{170}$

Meanwhile, Rabin's political lieutenants were not making ties with American

Jewry any easier. Some examples include:

- Finance Minister Avraham Shochat said that Israel Bonds were overpriced and Israel could get better rates on the open markets. ${ }^{171}$

${ }^{169}$ Ibid.

${ }^{170}$ Yitzhak Rabin. The Rabin Memoirs: Expanded Edition With Recent Speeches, New Photographs and an Afterward. (University of California Press: Berkeley, CA., 1996) pp. 198-200 (on Kissinger) and pp. 307309 (on Peres).

${ }^{171}$ Steven Bayme, "Israel and American Jewry: Oslo and Beyond." Institute for Global Jewish Affairs. Web. 15 Jan. 2008.

Some observers have categorized such comments and similar ones from these years from Israeli officials as part of the "post-Zionism" that had gained a foothold in left-wing Israeli academic circles. The ideology which began in the 1980s, is the broad term given to the ideology amongst left-wing Israeli academics seeking to create "a state for its citizens" and not a "Jewish democracy." It combined with the notion that Israel was a nation like all others and did not need charity from Jewish communities abroad.

However it is likely that post-Zionism was part of Rabin's personal ideology. Indeed, in his remarks to the Knesset after returning from Washington in September 1993, he invoked the calls of Judaism and Zionism: "Three days from now," he said, "every Jew everywhere will be enveloped in the holiness of Yom Kippur, the day for both national and personal spiritual stocktaking... On the eve of the 5,754 ${ }^{\text {th }}$ Yom Kippur, the government of Israel is presenting the people of Israel with a chance of peace, and perhaps of an end to wars, violence and terrorism... For one hundred years and more, we have been seeking to build ourselves a home in the only place on Earth that ever was or ever will be our home, here in the land of Israel. ${ }^{171}$ 
- Israeli President Ezer Weizman, also highly outspoken, told the AJCommittee board of governors that U.S. Jews only need to make aliyah and the country "had no need of their influence within the American polity."172

- Avraham Burg, head of the Jewish Agency for Israel, called for a $100^{\text {th }}$ anniversary conference to mark the original Zionist congress. At the event, delegates would declare the Zionist goal of creating a Jewish state complete and disband the World Zionist Organization. ${ }^{173}$

- Justice Minister Yossi Beilin, addressing the International Conference of the Woman's International Zionist Organization (WIZO), "shocked" delegates by telling them that they no longer needed to support Israel and should instead focus on strengthening North American Jewish education. ${ }^{174}$

When one gets past the anger caused by some of these remarks, in the pre-Oslo days Rabin also was pushing for a major revamping of Israel-Diaspora ties - something perhaps lost to American Jews long-accustomed to hearing only flowery rhetoric about Israel's long-term desire for peace amidst their continual struggles against anti-Israel violence. Still, Rabin began laying the groundwork for major change shortly after forming his government when he told the $32^{\text {nd }}$ World Zionist Congress meeting that "it is our intention to take vigorous steps to bring about the end of the Arab-Israeli conflict. We will do this on the basis of the recognition by Arab states and the Palestinians that Israel

\footnotetext{
${ }^{172}$ Ibid. Ironically, Weizmann's comments came at a Jerusalem conference he had convened of international Jewish leaders to discuss the future of Jewish peoplehood, or sense of collective fate. U.S. Jewish leader Shoshana Cardin - herself born in Palestine -- responded bitingly that American Jewry did not perceive itself as "cannon fodder" for aliyah.

${ }^{173}$ Yossi Beilin, His Brother's Keeper: Israel and Diaspora Jewry in the Twenty-first Century. (New York: Schocken Books, 2000), p. 112. Burg sought to revamp Diaspora-Israeli relations in 1995 when, as chairman of the Jewish Agency for Israel, he authored a monograph entitled Brit Am: A Covenant of the People, Proposed Policy Guidelines for the National Institutions of the Jewish People. His ideas to restructure the agency were not accepted.

${ }^{174}$ Bayme, "Israel and American Jewry: Oslo and Beyond." Beilin is an unusual case in that - while employing typical Israeli bluntness -- he seemed sincere in the effort to move Israel-Diaspora ties onto a healthier plane, as seen throughout his book His Brother's Keeper: Israel and Diaspora Jewry in the Twenty-first Century. After reviewing the failure and outdated nature of the structure of Diaspora-Israel ties, he offers suggestions such as creating an international Jewish parliament and what became the TaglitBirthright Israel trip for young adults.
} 
is a sovereign state and has the right to live in peace and security." ${ }^{175}$ Nearly eight months later - and six months before the Oslo signing - he told the 1993 AIPAC Policy Conference in Washington, D.C.:

Peace you make not with friends, but with your enemies and, therefore, there is a need to solve practical issues and to overcome psychological barriers - barriers that have been built in tens of years of violence, war, terror, hatred on both sides, and backlogs of negative emotions. ${ }^{176}$

\section{III.4 Washington and the Oslo Accords}

Unlike past agreements between Israel and Arab states, the creation of the first Oslo Accords, which began as an unofficial dialogue between Israeli academics and PLO representatives hosted by the Norwegian government, was driven by the parties themselves. Even though the U.S. knew that this unofficial back channel was proceeding, it was caught off guard by its ultimate success. That became evident in late August, 1993 when Rabin sent Israeli Foreign Minister Shimon Peres, accompanied by Norwegian Foreign Minister Johann Holst, to California to inform a surprised vacationing Secretary of State Warren Christopher of the mutual Israeli-P.L.O. recognition. ${ }^{177}$ Exhibiting the important standing U.S. Jews had in the political process, the U.S. official asked whether American Jewish leaders had yet been briefed. ${ }^{178}$ They had not and it is somewhat remarkable that Christopher would think U.S. Jewish leaders would know of this before he would. Meanwhile, Peres was so eager to gain U.S. support for the agreement that he

\footnotetext{
175 “Address by Prime Minister Rabin to the 32 ${ }^{\text {nd }}$ Zionist Congress - 30 July 1992.” Web. 15 March 2009.

176 “Address by Prime Minister Rabin to AIPAC Conference - 21 March 1993.” Web. 15 March 2009.

${ }^{177}$ Quandt, p. 328.

${ }^{178}$ Gruen, “Jewish Attitudes Toward Israel: Continued Support in the Face of Dramatic Change," p. 68.
} 
even offered to Christopher that he would tell the world that the Clinton administration was its author. ${ }^{179}$

The need for official and unofficial U.S. approval again displayed how heavily dependent Israel had become on Washington. Indeed, with Washington now the only superpower - the political and economic strength of the Soviet Union and then Russia in rapid decline in the early 1990 s - it is unlikely that the world community's backing of the Olso process (particularly financially) would have been as enthusiastic.

The Oslo signing itself was a spectacular diplomatic event. Giving weight to the importance of the day, attending the White House signing ceremony were former U.S. Presidents Ford, Carter and Bush, former Secretaries of State, Congressional leaders and leading figures from the Arab world- not to mention the international media, particularly from Israel and many Arab states. ${ }^{180}$ As a prelude to the micro-managing role the U.S. would soon take in seeking to bring the peace effort to fruition, the moments before the event were spent by top U.S. aides trying to persuade Arafat not to show up in uniform and with his omnipresent pistol in holder. (He came without the pistol, but in uniform). Meanwhile, Rabin had to persuaded to even show up in the same venue with Arafat. ${ }^{181}$ After Clinton famously nudged Rabin to shake the hand of the beaming Arafat, with little fanfare the U.S.-backed, multi-national/multi-lateral Madrid process had

\footnotetext{
${ }^{179}$ Warren Christopher. Chances Of A Lifetime: A Memoir. (New York: Scribner, 2001), p. 200. Christopher rejected the offer but agreed that the United States would be pleased to host a signing ceremony.

${ }^{180}$ Thomas L. Friedman, "Rabin And Arafat Seal Their Accord As Clinton Applauds 'Brave Gamble.' New York Times. 14 September 1993. Also, see Clinton, pp. 542-545.

${ }^{181}$ Dennis Ross, The Missing Peace: The Inside Story of the Fight For Middle East Peace. (New York: Farrar, Straus and Giroux, 2004), pp. 119-121.
} 
become irrelevant; the major parties of the conflict - the Palestine Liberation Organization and the State of Israel - were for the first time in official, direct negotiations.

The Clinton administration then moved into high gear to ensure the success of the process. A major step came in the U.S. convening of a donors' conference to raise $\$ 2$ billion - including \$500 million form the United States - for a Palestinian governing civilian infrastructure to be controlled by the newly created Palestinian Authority. ${ }^{182}$

\section{III.5 American Jewry's Response To The Oslo Accords}

American Jewry's response to the Oslo Accord was overwhelmingly positive. In fact, 90 percent of American Jews viewed mutual recognition as a "positive development from Israel's point of view." ${ }^{183}$ After all, "a genuine Israeli military hero stood face to face, albeit uncomfortably, with a personality long regarded as one of the world's archterrorists." That had a major implication as "overnight, Jewish groups faced a radically altered landscape."184 The dilemma was clear immediately to many top activists. In reporting on the Oslo signing, the Baltimore Jewish Times quoted veterans of organized American Jewish life such as Earl Raab of Brandeis University, who worried that

\footnotetext{
${ }^{182}$ Leon Hadar, "The real Lesson of the Oslo Accord: 'Localize' the Arab-Israeli Conflict.” (The CATO Institute Foreign Policy Briefing No. 31.May 9, 1994, Washington, D.C.). Web. 1 March 2009. This money was intended specifically for the Gaza Strip and Jericho, which were to first experience full Palestinian autonomy as a test for expanding Palestinian rule. Hence, the initial Oslo Accord is sometimes referred to as the "Gaza-Jericho First Plan." The U.S. pledge was over five years and administered by the Overseas Private Investment Corporation.

${ }^{183}$ Lawrence Grossman. "Jewish Communal Affairs," in American Jewish Yearbook (New York and Philadelphia: The American Jewish Committee and The Jewish Publication Society, 1995), p. 156.

${ }^{184}$ Raffel, "History of Israel Advocacy.” (New York: Rowman and Littlefield, 2002), p. 152.
} 
financial contributions could dip in part due to "a decline in political activity on behalf of Israel.” Likewise, AJCommittee top professional David Harris echoed, "For many Jews, it's been the threat to Israel that has kept the bond as strong as it has been."185

The reaction of the board of the AJCommittee, which gathered in New York City to watch the signing ceremony on television, captured the intense optimism of many. The group's president, Robert S. Rifkind, asked everyone to recite a biblical prayer of thanks to God. ${ }^{186}$ Still, a note of caution was injected into the atmosphere when via telephone speaker AJCommittee Israel office director Michael Oren noted that he could look out his Jerusalem office window and see three things: rock bands playing on huge television screens that Peace Now had rented to rally in favor of the Accord, PLO flags waving over the city's eastern half (still technically illegal); and right-wing demonstrators saying Kaddish - the Jewish prayer for the dead - over a cauldron of ashes. ${ }^{187}$

Back in the United States, one byproduct of this new era was a warming of ties between U.S. Jewish and Arab-American groups. It began on the evening of September 13, 1993 in Washington, D.C., with a reception co-sponsored by Project Nishma (a Jewish pro-peace group that later became the Israel Policy Forum), the American Jewish Congress, and the Arab American Association. Afterwards, the AJCongress drew up a list of joint activities for U.S. Jewish and Arab groups. The head of the Arab group was so taken aback by the pace at which official attitudes had changed that he reportedly said,

\footnotetext{
185 James D. Besser. “What's Next For Jewish Groups?” Baltimore Jewish Times, 17 September, 1993, pp. 46-47.

186 Marianne R. Sanua, Let Us Prove Strong: The American Jewish Committee 1945-2006. (Waltham, Mass.: Brandeis Univeristy Press, 2007), p. 343.

${ }^{187}$ Ibid, 344. The choice of ashes was extremely powerful as it denoted the crematoria into which the Nazis shoved and burned Jewish corpses. In addition, cremation is a violation of Jewish law.
} 
"It's a positive development. But we want to make sure people do not hug each other to death."188

Nonetheless, about six months later, on May 4, 1995, the NJCRAC and the National Association of Arab Americans released an unprecedented joint "Statement of Principles on Jewish-Arab Relations." It stated in addition to moving to "condemn unequivocally all terrorist acts, defined as politically motivated acts of violence against civilians, whatever their origin," that they rejected stereotyping (long an issue for Arab American groups), applauded U.S. support for the peace process, and would not allow different perspectives "to damage our relationship, or to deter our two communities from continued cooperation on behalf of shared goals and interests."189

\section{III.6 A Post-Oslo American Jewish Agenda}

As the reality of the Oslo Accords began to sink in, a large swath of organized American Jewry began accepting its successful conclusion as a fait accompli. Major groups began wrestling with a question that until now had been as wistful as theoretical: If peace really is around the corner, and we have spent these past decades defending an Israel in physical danger, what shape will our relationship to the Jewish state now take?

The need for American Jewry to create a post-Oslo agenda was laid out forcefully by none other than Rabin himself, which on its own was a strong statement as to how events in Israel could set the agenda for North American Jewry. Two months after the

\footnotetext{
${ }^{188}$ Grossman, “Jewish Communal Affairs,” 1995, p. 156.

189 "Statement of Principles on Jewish-Arab Relations," 4 May 1995. Jewish Council for Public Affairs. Web. 20 March 2009.
} 
Washington signing, Rabin used his 1993 General Assembly of the Council of Jewish

Federations speech to tell North American Jewish leaders that he understood their security fears, but that:

We should be preparing now for the day in which new issues will occupy our hearts and minds because our support for Israel and our identification with Israel is based on more than the external threats to Israel... We are a land flowing with milk, honey and micro-chips. We welcome your investments, and you are welcome to the dividends.

Then, in language meant to evoke the grand nature of the Jewish state, he began his concluding section with these words:

I have met with many of you in Israel in the past months, and I have seen your eagerness to face the demands of our new reality in the contest of a true partnership. This is the time to rewrite the covenant between Israel and world Jewry. The thrust of that covenant must be Jewish continuity and survival through the reclamation of our youth. This is our challenge as a people. ${ }^{190}$

Rabin continued to embrace such themes. On December 12, 1994, from Jerusalem he held a video teleconference with Jewish activists throughout the United States in which part of the goal was to keep American Jews active in lobbying Washington to support the peace process as well as simply maintaining the State of Israel's primacy on the American Jewish agenda. ${ }^{191}$ As such, the AJCommittee 1994 Board of Governors meeting - held in Jerusalem -- was called "When Peace Comes." 192

In striking out to develop a new Diaspora-Israel relationship, the first challenge was to find consensus within the American Jewish community. At the first annual JCPA

\footnotetext{
${ }^{190}$ Yitzhak Rabin, “Address by Prime Minister Rabin to the General Assembly of the Council of Jewish Federations-Montreal-18 November 1993.” Web. 25 March 2009.

${ }^{191}$ James D. Besser, “Message For A Changing Era,” in Baltimore Jewish Times. 16 December 1994, pp. 24-25.

${ }^{192}$ Bayme, "Israel and American Jewry: Oslo and Beyond."
} 
Plenum since the Oslo signing, the body passed a "Statement on the Middle East Peace Process." It said the group "strongly supports the peace initiatives undertaken by the Rabin government," but added that the burden was with the PLO "particularly with respect to ending violence and terrorism" and "Israel's security is far from assured." Therefore, it continued, "it is essential that the U.S. continue to fulfill its longstanding commitment to maintain Israel's qualitative military edge."193

Further, on June 13, 1994, the JCPA executive passed a resolution that said the group "continues to strongly support the peace process" but that "additional efforts are necessary" since peace "depends in large measure on the success of the Palestinian Authority ... to curb terrorism and to develop the kind of economic institutions that will give confidence to an international community committed to Palestinian development." The document reemphasized "the unified commitment of world Jewry to maintain the city of Jerusalem as the eternal undivided capital of Israel." ${ }^{194}$ A near parallel document was passed the next year. ${ }^{195}$

Influential academics such as Dr. Steven Bayme laid out the challenges to the American Jewish Press Association in a 1994 address at the group's annual convention. He framed the shifting relationship between Israeli and American Jews in the context of the continuity agenda, describing both the shared and different challenges of the

\footnotetext{
193 "Statement on the Middle East Peace Process, adopted by the NJCRAC Annual Policy Conference, 21 February 1994.” Web. 5 April 2009.

194 “Resolution on Jerusalem, adopted by the NJCRAC Executive Committee, 13 June 1994.” Web. 5 April 2009.

195 "Statement on the Middle East Peace Process, adopted by the NJCRAC Executive Committee, 23 October, 1995 and "Resolution on Jerusalem, adopted by the NJCRAC Executive Committee, 13 June 1994.” Web. 5 April 2009.
} 
communities. "Too much confidence is being placed in the Israel experience as the centerpiece of the Jewish continuity agenda," he said. Rather, a commitment to leading a Jewish life - regardless of how one consciously defines that - should be broader and deeper while including a devotion to the well-being of a Jewish state. ${ }^{196}$

Also recognizing the need for new language, on February 11, 1995 the AJCommittee board of directors approved a policy statement on Israel-Diaspora Relations. In language unthinkable not long ago, the document declared:

As American Jews grapple with their critical task of ensuring their future continuity, Israel shares the responsibility to assist American Jewry in meeting their challenge. Moreover, American Jewry has a stake in and responsibility for helping ensure the continued salience and presence of Judaic values within Israeli society... For American Jewry, Jewish identity is generally personal and voluntary. For Israelis, by contrast, a Jewish society bestows a collective identity suggesting participation in a national endeavor. Both expressions enrich one another. ${ }^{197}$

Meanwhile, both the Oslo Accords and the growth of American Jewish foundations created new initiatives to help American Jews have a stake in shaping Israel's future. These were seen through the stepped up efforts of groups such as the Abraham Fun, and the growth of the New Israel Fund, both of which sought to address Israel's unmet social needs. ${ }^{198}$

\footnotetext{
${ }^{196}$ Steven Bayme, "Changing Patterns in Israel-Diaspora Relations.” (New York: American Jewish Committee, 1994), p. 11.

197 “AJC On Israel Diaspora-Relations: A Policy Statement Adopted by the Board of Governors, February 11, 1995.” Web. 20 April 2009.

${ }^{198}$ For more information see <http://www.abrahamfund.org>. The group, founded in 1989, focuses on Israeli Jewish/Israeli Arab co-existence efforts. For more information see <http://www.nif.org >. Founded in 1979, NIF works for "social justice and equality for all Israelis," which means funding projects for Israeli Arabs as well as Jews.
} 
Likewise, issues such as the absorption of Ethiopian Jews became more important for American Jewry as, under the leadership of the American Jewish Joint Distribution Committee, a coalition was formed to help these new immigrants integrate to the Jewish state. ${ }^{199}$ The National Council of Jewish Women pioneered the Israeli Home Instruction Program for Pre-School Youngsters (HIPPY), which helps Israeli mothers from low socio-economic backgrounds bolster their children's pre-school experience. ${ }^{200}$

Numerous Jewish foundations and federations pushed different forms of involvement in Israeli society. This came through starting or giving new emphasis to organizations designed to promote business ties, such as the Georgia-Israel Chamber of Commerce and the Maryland-Israel Development Center. Similar operations began appearing throughout the United States as various governors took trade missions to Israel with leading Jewish business figures.

People-to-people contacts were put into high gear as well. These included funding for scholarships for youth to attend trips to Israel as well as to bring Israelis to the United States. The most celebrated and visible effort was Taglit-Birthright Israel, which remains in existence today. The free 10-day trip seeks to bring every Jewish young adult, ages 18 to 26 to Israel for free, assuming participants had not already visited the Jewish state on another peer trip. But it also had both a larger intent and result beyond stoking Jewish identity in young adults. It sought to cement a partnership amongst its funding partners major philanthropists (primarily in the United States), the Government of Israel, and

\footnotetext{
${ }^{199}$ Martin J. Raffel, “American Jewish Public Affairs and Israel: Looking Back, Looking Ahead.” The Reconstructionist Spring 63:2 (1998): 63.

${ }^{200}$ Ibid, p. 64.
} 
North America's Jewish federations. This alone spoke volumes in terms of the shifts in Israel-Diaspora ties as Jerusalem was looked on by Jews abroad as a full partner in cultivating Jewish identity overseas, which in turn would bolster the Jewish state either through future immigration or sensitivity for Israel's concerns.

Meanwhile, volunteer groups such as the Israel Forum - a partnership between young professionals in both Israel and the United States - took off. Operations such as the U.S.-based Israel Democracy Institute, founded in 1991, which were primarily funded by North American Jews, grew.

Jewish sociologists and activists also began to give heavy focus to plans to energize the Diaspora-Israel ties. For example, Isi Liebler, a longtime World Jewish Congress leader, in 1994 published the monograph The Israel-Diaspora Identity Crisis: A Looming Disaster. He wrote of the need to kick start funding for Jewish education as well as the dual challenge to Diaspora Jews of relating to Israel's polar opposites - "religious radicalism" and "secular extremism."201

Still, an ongoing concern throughout the 1990s amongst American Jewish activists was the increasing erosion of grassroots activism. The Jewish continuity push of the early 1990s developed into what became known as "Jewish renewal" or "Jewish renaissance" (in large part spurred on by the successful use of such terminology by Richard Joel as head of Hillel: Foundations for Campus Jewish Life).

Spirituality became the zeitgeist not for all, but for an increasing array of Jewish activists. Indeed, at the December 1999 Union of American Hebrew Congregations

\footnotetext{
${ }^{201}$ Isi Liebler. "The Israel-Diaspora Identity Crisis: A Looming Disaster.” (New York: World Jewish Congress, 1994).
} 
(Reform movement) biennial, workshops on Israel and social activism drew fewer participants than in past years as ones on "God and Theology" and "Torah and Observance in the Principles of Reform" were the most popular offerings. ${ }^{202}$ Likewise, leaders such as Shoshana S. Cardin were publicly voicing concern that "Israel did eclipse our spiritual progress." ${ }^{, 203}$ Finally, theological leaders struggled with how to relate to an Israel advancing down the peace front. As such, the Spring 1998 journal of the Reform rabbinate dedicated itself to a symposium entitled "Reform Judaism and Zionism." Its entries included entries titled "The New Zionism for the New Zionist Century," “Missing: The Centrality of Israel," and "Hatzi [Half] Zionism.” 204

\section{III.7 Tensions Within Organized Jewish Life}

While all these newer initiatives were either being established or enhanced, the impressive pro-Israel bent of American Jewry was in turmoil. In fact, the peace process gave birth and emphasis to new and existing ideological groups, which in turn created additional tensions for American Jews.

One of the more visible internal fights came in December 1993 within the Zionist Organization America (which claimed 100,000 members at the time). Baltimore's W. James Schiller was defeated for a second term as President of the group by right-wing activist Morton Klein from Philadelphia. While ZOA had always taken a hard line on both Israel's negotiations, and on U.S. ties with the Arab states and the Palestinians, its

\footnotetext{
${ }^{202}$ Raffel, "History of Israel Advocacy,” p. 155.

${ }^{203}$ Arthur J. Magida. “The Peace Dividend,” Baltimore Jewish Times, 12 November 1993, pp. 60-63.

${ }^{204}$ CCAR Journal, Spring 46:2 (1998).
} 
leaders generally adhered to a philosophy of not publicly criticizing the democratically elected government of Israel. Klein, who openly opposed the Oslo Accords, vocally clashed with Schiller on that. ${ }^{205}$ He also went on to defeat Schiller for the organization's top spot -- but not without a cost. Schiller pulled his home group, the Baltimore ZOA chapter, out of the organization and formed the independent Baltimore Zionist District.

Meanwhile, a similar fight had taken place earlier in the year when pro-peace group, American Friends of Peace Now - the U.S. based affiliate of Israel's Peace Now successfully applied for membership to the President's Conference. The winning argument of the day became "How could the American Jewish community refuse to grant legitimacy to a group that had members serving in the cabinet of Yitzhak Rabin?" 206 A local echo was felt as the Baltimore Jewish Council, the central community relations organization, was petitioned by Baltimore Friends of Peace Now. There, the debate was minimal as the group was welcomed by a vote of 63 to 1 , the only dissent coming from the diminished but still functioning Baltimore ZOA chapter. ${ }^{207}$

There also was a disturbing trend developing amongst U.S. process supporters, one that did not at first garner much attention: Jewish support for the peace talks was slowly dropping. On September 12, 1994 - one day shy of the two -year anniversary of first Oslo Accord signing - the AJCommittee released a national survey that showed 68 percent of American Jews favored the peace process. While still a healthy majority, this

\footnotetext{
${ }^{205}$ James D. Besser. “ZOA Leadership Fight Reflects Mideast Changes,” Baltimore Jewish Times, 10 December 1993, pp. 39-40.

${ }^{206}$ Jack Wertheimer, "Breaking the Taboo: Critics of Israel and the American Jewish Establishment," ed. Allon Gal, Envisioning Israel (Jerusalem: Magnes Press; Detroit: Wayne State University Press, 1996), pp. 416-417.

${ }^{207}$ Ira Rifkin. “BJC Accepts Peace Now,” Baltimore Jewish Times, 22 December 1993, p. 22.
} 
was down from 77 percent the previous year and a much stronger 84 percent in $1993 .{ }^{208}$ This drop occurred amidst horrible suicide bombings by Palestinian terrorist groups on Israeli public buses and elsewhere.

In the United States, the anti-Rabin rhetoric was heating up. One example came in the popular ultra-Orthodox newspaper the Jewish Press. Week after week the Brooklynbased publication had "vitriolic anti-Rabin editorials and news columns, often drawing parallels between the Israeli government and the Nazis." ${ }^{209}$ Israeli representatives in the United States were also targeted. When speaking at a New York synagogue, Ambassador Itamar Rabinovich was pelted with an egg and New York Consul General Colette Avital was jostled during a local Israel Independence Day celebration. ${ }^{210}$

The tensions were also on display when NJCRAC hosted Arafat himself at a meeting in New York City on October 23, 1995. A number of national organizations declined to attend, saying that they had not been consulted about the invitation ${ }^{211}$ (an invitation they likely would have balked at anyway). NJCRAC had always prided itself on being one of the few agencies that could bring together all segments of the community to have civil conversations on what united and divided the community.

\footnotetext{
${ }^{208}$ Lawrence Grossman, "Jewish Communal Affairs.” American Jewish Yearbook 1997. (New York and Philadelphia: The American Jewish Committee and The Jewish Publication Society, 1997), p. 178. Also see Yale M. Zussman. "How Much Do American Jews Support the Peace Process?" Middle East Quarterly. December 1998.

${ }^{209}$ Grossman, "Jewish Communal Affairs," American Jewish Yearbook 1997, p. 176. While, as reviewed in Chapter One, the ultra-Orthodox community is technically non-Zionist, its general sentiment is right-wing on Israeli politics as seen in the votes of its community in Israeli national elections.

${ }^{210}$ Raffel, "History of Israel Advocacy,” p. 157.

${ }^{211}$ Grossman, “American Jewish Communal Affairs.” American Jewish Yearbook 1997, p.181.
} 


\section{III.8 Orthodox And Non-Orthodox Divide}

Orthodoxy Jewry's support for the Oslo Accords was never as high as that of the rest of the American Jewish community. Yet, it did start out with a slim majority - 52 percent initially favoring the document and only 32 percent saying they were opposed (about 15 percent remaining “not sure.”). By contrast, only 5 percent of Reform Jews and 9 percent of Conservative Jews were opposed to the negotiations. ${ }^{212}$ Since Orthodox Jews, as previously stated, were only about 10 percent of the U.S. population, the number of opponents to the peace initiative was relatively small. However, they were vocal and gained visibility in the media and at community events. Still, the leadership of the largest Orthodox group, the Orthodox Union, publicly did not criticize Rabin due to not wanting to criticize the democratically elected government. Still, in private doubts mounted. ${ }^{213}$

Peres did not help matters. On September 27, 1993, prior to an address to the United Nations, he said, that Orthodox rabbis “don't have permission of the Lord to give preference to territory over spirit." ${ }^{, 214}$ Certainly, from the perspective of those rabbis, Peres, a secular leader, did not have permission to embark on a land for peace path. By the time of the second Oslo signing in October 1995, the split between Orthodox and non-Orthodox Jews on the peace process was clear. In fact, during the

\footnotetext{
${ }^{212}$ Gruen, "American Jewish Attitudes Toward Israel: Continued Support in the Face of Dramatic Change," p. 60. A post-Rabin assassination survey by the AJCommittee did find a jump in support across the board. The overall American Jewish community's approval rose from 68 percent to 79 percent; within Orthodoxy opposition dropped from 64 percent to 56 percent - still a majority. See Grossman, "American Jewish Communal Affairs," American Jewish Yearbook 1997, p. 187.

${ }^{213}$ Mendy Granchow, Journey Through The Minefields: From Vietnam to Washington: An Unorthodox Surgeon's Journey. (Silver Spring, Md.: Eshel Books, 2004), p. 226.

${ }^{214}$ Lawrence Grossman. “American Jewish Communal Affairs.” American Jewish Yearbook 1995. (New York and Philadelphia: The American Jewish Committee and The Jewish Publication Society, 1995), p. 158.
} 
Washington, D.C. ceremony itself, competing blasts of the ram's horn - the ancient Jewish symbol heralding both great moments of peace or a call to war - were heard outside of the White House. The first set came from pro-Oslo supporters affiliated with Project Nishmah, who were demonstrating in Lafeyette Park across from the White House. Not long after a second set of blasts came from anti-peace process demonstrators on the other side of the White House, these coming from participants in a protest organized by the National Council of Young Israel, a Zionist modern Orthodox synagogue group. Some at the second rally held signs declaring "Rabin Has Betrayed Zion" and "One Holocaust Is Enough.",215

Also, on October 9, 1995 New York magazine interviewed Rabbi Abraham Hecht, who four months earlier had approved the assassination of anyone who handed Jewish land to non-Jews. In asking how he would feel if Rabin was assassinated, the Rabbi said, "I wouldn't feel... Rabin is not a Jew any longer. The man has done so much harm. I can't forgive him for that." ${ }^{, 16}$

Much of the Orthodox extreme distaste for the "land for peace" formula at the heart of the Oslo process came from their belief that Jews were not allowed to relinquish sacred lands - the West Bank being the core of the biblical homeland of ancient Judea and Samaria - to non-Jews. This clearly brought to the fore the clash between democracy

\footnotetext{
${ }^{215}$ Grossman, “American Jewish Communal Affairs.” American Jewish Yearbook 1997, pp.179-180.

${ }^{216}$ Ibid, 181. After a public outcry, Rabbi Hecht was forced to apologize for his remarks.
} 
and Jewish law, which met in the amorphous concept of the State of Israel being a Jewish democracy. ${ }^{217}$

In addition to interpretations of Jewish law, what can explain the gap between Orthodox and non-Orthodox Jews on the peace process? Orthodox Jews as a whole were unquestionably more focused on the State of Israel and its policies than most other American Jews. Orthodox families who send children to college are generally expected to first send their offspring to Israel for a year of study between high school and college. The results show: while only about one-tenth of the U.S. Jewish population, they represent about one-third of American Jews who have visited the Jewish state more than once and 40 percent of those who speak Hebrew. In addition, about two-thirds of U.S. Orthodox Jews report they follow the news from Israel "very closely."218 This closeness is logically attuned in part to the concerns of Israel's Orthodox Jews, a group more skeptical about giving up sacred West Bank lands than the rest of Israel's population. In fact, American Orthodox synagogues frequently hosted Orthodox Israelis from settlements or right-wing political parties, delivering a right-wing bent on the Oslo process.

\section{III.9 Washington's Response to the Rabin Assassination}

As such tensions mounted, the seemingly unthinkable happened. Rabin was assassinated on November 4, 1995 at the end of a large peace rally in Tel Aviv. The sense

\footnotetext{
${ }^{217}$ For more, see Gerald M. Steinberg, "Interpretations Of Jewish Tradition On Democracy, Land, And Peace." Jerusalem Viewpoints. (Jerusalem: Jerusalem Center for Public Affairs, 2000). Web. 20 May 2009.

${ }^{218}$ Yale Zussman, "How Much Do American Jews Support the Peace Process?” Middle East Quarterly 5.4 (1998): 9.
} 
of devastation for those in Washington who worked closely with Rabin was profound.

Dennis Ross, sitting at his kitchen table while trying to write a statement for Secretary of State Warren Christopher broke down and cried. ${ }^{219}$

The personal recollections flowed. Richard Haas, a senior Middle East staff member at the White House during the presidency of George H.W. Bush, recalled being Rabin's tennis partner at Mr. Bush's Maine vacation house in 1992. "Rabin kept hitting the ball out or into the net and he kept saying he was sorry ... That's what I liked about him - he was totally lacking in airs. He was tough but he wasn’t ideological.,"220

Nothing, however, could match the emotional response of Clinton. Indeed, the president's childhood preacher would have been proud to hear the president's impromptu and emotional remarks at a hastily arranged press conference after confirmation of the Israeli's assassination, words likely to be quoted by students of American Jewish history as the hallmark - at least until that time - of closeness between an American and Israeli leader. Clinton's "Shalom chaver" (goodbye friend) comment even became a bumper sticker printed in Israeli newspapers and handed out on the streets. The words were repeated two days later at Rabin's funeral in Jerusalem in front of an impressive gathering of the world's leaders, particularly Arab ones. ${ }^{221}$

\footnotetext{
${ }^{219}$ Ross, p. 210.

${ }^{220}$ Elaine Sciolino, "Assassination in Israel: Washington: American Officials Warmly Remember Rabin As A Friend They Came To Trust Deeply." New York Times. 6 November 1995.

${ }^{221}$ Clinton's eulogy at the funeral is available at <http://www.mfa.gov.il/MFA/MFAArchive/1990_1999/1995/11/Rabin\%20Eulogy$\% 20$ President $\% 20$ Clinton $>$. Clinton also spoke in his remarks about the last time he had seen Rabin. Two weeks earlier, he said, they were at a black tie event but Rabin, known for his informality, did not have a black tie. "And so he borrowed a tie and I was privileged to straighten it for him. It is a moment I will cherish as long as I live." The funeral marked Egyptian President Hosni Mubarak's first trip to Israel, despite having led his country for 12 years, a period that began after the Israeli-Egyptian Peace Treaty was signed. Jordan's King Hussein returned to Jerusalem for the first time since seeing his grandfather, King
} 
Immediately after the funeral, still in Jerusalem, Clinton and his negotiating team spent every moment in a meeting with a principle Arab or Israeli negotiator, trying to insure that the peace process would not stop. ${ }^{222}$

Suddenly, Washington was now dealing with Peres as prime minister. Yet, the former Israeli Foreign Minister - often described as the architect of the Oslo Accords could not match his predecessor's standing with Washington in experience or in trust. ${ }^{223}$ Besides, Peres was almost immediately in a reelection campaign, thus limiting his ability to act. A string of particularly bad suicide bombings in February and March 1996 and then the military campaign, Operation Grapes of Wrath (conducted in Southern Lebanon), were other major distractions. ${ }^{224}$

Still, the White House all but openly bolstered Peres's 1996 election bid. While not wanting to be seen as interfering in Israeli politics, the Clinton team clearly rooted for Peres, fearing that the Likud's Binyamin "Bibi” Netanyahu would at best dramatically slow down the peace process. At one point, senior Clinton officials agreed with Peres's request late in the campaign to announce that the U.S. was prepared to move its embassy to Jerusalem, figuring that could bolster confidence in the Labor Party Prime Minister in what was going to be a close election. Yet, Assistant Secretary of State Sandy Berger vetoed the idea. Peres lost the vote, which left Dennis Ross wondering if the embassy

\footnotetext{
Abdullah, assassinated there by a Palestinian afraid that the Jordanian would make a separate peace with Israel.

${ }^{222}$ Ross, pp. 212-215.

${ }^{223}$ Christopher, pp. 198-199. The Secretary of State notes that he was always aware of the distrust Rabin had for Peres and that "Rabin had indicated to me that my dealings on matters of substance should be with him, and that he, in turn, would brief Peres."

${ }^{224}$ Michael Bar-Zohar. Shimon Peres: The Biography. (New York: Random House), pp. 466-467.
} 
move - which he was certain Clinton would have approved - could have changed Peres's defeat. ${ }^{225}$

\section{III.10 Rabin Assassination And American Jews}

As in Israel, for many American Jews the murder was personal. They had either met or heard Rabin at some event during the past 25 years, or simply admired him from afar as the embodiment of the confident, strong new Jew that the State of Israel could produce. They, too, were in a state of shock. Within days, large memorial ceremonies were held in every Jewish community around the country, often attracting U.S. Senators, governors and other top elected officials. Orthodox opponents of the peace process were both stunned and concerned about being blamed. Sensing the depths of the tragedy, the Orthodox Rabbi Avi Weiss said, "This is time of grave darkness for the Jewish people. I hope there will be an outpouring of mourning, of such love and unity that it dispels the deep hate that has engulfed us." ${ }^{226}$ Some non-Orthodox leaders such as Gary Rubin of Americans for Peace Now vowed to continue their support for the peace process with renewed vigor. ${ }^{227}$

However, the intense tensions brought to the fore by Rabin's peace policies were not cast aside. A month after the murder, the Presidents Conference held a memorial ceremony in the slain prime minister's memory. While about 14,000 people packed Madison Square Garden on December 10 to hear from people such as new Israeli Prime

${ }^{225}$ Ross, p. 257.

${ }^{226}$ Clyde Haberman, “Assassination In Israel: American Jews, Leaders Lay Politics Aside To Mourn Death Of Rabin. New York Times. 5 November 1995.

${ }^{227}$ Ibid. 
Minister Shimon Peres and U.S. Vice President Al Gore, there was concern that Orthodox Jews would not show up. In fact, the largest American Orthodox Jewish group, the Orthodox Union, held a debate on whether to participate. They finally agreed to do so and even became a sponsor, but the fact that their official appearance was in question showed how divisive Israel's policies had become for a community once much more united over Jerusalem's decisions. While one-third of the crowd was estimated to be Orthodox, that was in part due to the location being New York City, which has high numbers of Orthodox Jews. The National Council of Young Israel (joined by the secular, right-wing ZOA) opposed the event as partisan as no speakers from the opposition Likud Party spoke. $^{228}$

A day after the Madison Square Garden event, the AJCommittee hosted a symposium with national Jewish leaders called “Are We Still One People?” Two months later, the organization followed the initiative with the printing of a 100-page booklet entitled "Rebuilding Jewish Peoplehood: Where Do We Go From Here?" It contained responses by 32 leading Israeli and American Jewish figures from across the religious and political spectrum. In 1997, the AJCommittee then held a second conference on the topic and published another series of essays, this one called "The Condition of Jewish Peoplehood," which reflected the views of a similar array of Jewish voices. ${ }^{229}$

\footnotetext{
${ }^{228}$ Cynthia Mann, "Hopes for Unity Prove Elusive at Memorial, Peace Rally in New York," Jewish Telegraphic Agency, 11 December 1995. This reflects the near uniform nature of response in Orthodox circles (particularly Haredi or ultra-Orthodox ones) to the desires of their leaders. Had the leaders signaled that the event was not appropriate for their community, the Orthodox attendance would have been minimal. Also see Peter Steinfels, "In Memorial For Rabin, Jews Forge Fragile Unity." New York Times. 8 December 1995.

${ }^{229}$ Sanua, 390-391. The final essays reflected that the concepts for Jewish unity had improved. However, that seemed more of a desired sentiment than an empirical reality.
} 
The U.S. Jewish media reflected the shock of the assassination. Tikkun, a national liberal Jewish magazine, devoted its January-February 1996 issue to the assassination's impact and what would come next. The Friday after the murder, the Baltimore Jewish Times, Atlanta Jewish Times and Detroit Jewish News ran an unprecedented 20 to 30 pages with no advertisements, but only articles about reaction to the assassination.

Jewish educators also saw the tragedy as a painful opportunity to focus positively on the emotions brought forward. No greater evidence came than in 1996 when the Journal of Jewish Education devoted an entire issue to the murder. Its 17 articles included "Confronting the Rabin Assassination in Our Educational Institutions," "Whither Jewish Education? The Educational Meaning of a Transformational Event," and "Grasping A Teachable Moment.",230

Also, the OU produced the "One Thousand Homes of Dialogue" program, in which small groups - aimed to be comprised of Orthodox and non-Orthodox Jews - held civil discussion in private homes on controversial issues. The OU put together packets on contemporary topics and how they played out in Jewish ethics as discussed in classical sources. $^{231}$

Not surprisingly, the assassination put Orthodox Jews on the defensive. After all, one of their own, one raised in a religious Zionist environment, had both murdered the leader of the Jewish state and used Jewish law as his justification. The American Jewish community "seemed perilously close to civil war," according to OU leader Mendy Ganchrow. He and other Orthodox leaders tried to distance their community from the acts

\footnotetext{
${ }^{230}$ Journal of Jewish Education. Vol. 62:2 (1996).

${ }^{231}$ Lawrence Grossman. “Jewish Communal Affairs,” in American Jewish Yearbook 1997, p. 183.
} 
of Rabin's assassin, Yigal Amir, even publishing newspaper announcements "to make the point that the Orthodox community mourned for Rabin and was determined to avoid further bloodshed.",232

For his part, Peres made attempts to shift the tone of the harsh dissent coming from the Diaspora during his brief tenure. He appointed Rabbi Yehuda Amital as a minister without a portfolio, charging the pro-peace process Orthodox rabbi with creating a dialogue with settlers and the Diaspora on the need to move forward with the Oslo Accords. ${ }^{233}$ Amital was not only the founder of a widely respected West Bank yeshiva, the Har Etzion Yeshiva in Alon Shvut, but a creator of the pro-peace religious political party Meimad. In short, he was a man whose religious legitimacy could not be questioned (although his left-center politics were), enabling him to speak with Orthodox opponents of the peace process in their own terminology.

Then it was back to lobbying. In December 1995 AIPAC, JCPA and the President's Conference organized a "National Peace Process Advocacy Day" in Washington, D.C. to dramatize American Jewish support for Israel. ${ }^{234}$

Nonetheless, Peres would lose by less than one percent of the vote in the May 29, 1996 Israel national elections. Suddenly, Washington, American Jewry and the world faced an Israeli prime minister who had voted against the Oslo signings in the Knesset and who had been elected with the slogan "Netanyahu will make a secure peace." By

\footnotetext{
${ }^{232}$ Ganchrow, pp. 233-234.

${ }^{233}$ Larry Derfner, “Lonely Man Of Faith.” Jerusalem Post. 22 December 1995. Amital also came to the United States to hold conversations with American Orthodox rabbis on behalf of Peres. Netanyahu did not continue Amital's government service. However, he put Bobby Brown, an American-born modern Orthodox resident of the West Bank town Tekoa, in charge of Diaspora-Israeli relations.

${ }^{234}$ Raffel, “American Jewish Public Affairs and Israel: Looking Back, Looking Ahead,” p. 59.
} 
that, Binyamin Netanyahu telegraphed that he would take a much harder line in the negotiations, even suspending them if Palestinian terror attacks and incitement did not halt. For American Jews, however, Netanyahu's time in office from 1996-99 would lead to challenges on the Diaspora-Israel front that went far beyond the simple like or dislike of Israel's peace process policies. 


\section{Chapter IV. The Netanyahu Years}

\section{IV.1 Post-Rabin Assassination To Wye}

For most close observers of the White House and its Mideast policy, there was no doubt that the Clinton administration had all but publicly tipped its hand toward incumbent Shimon Peres as Israel's 1996 elections drew near. As Baltimore Jewish

Times Washington correspondent James D. Besser wrote just prior to Israel's national elections:

"In 1996, the Clinton administration has gone farther than any of its predecessors in linking American Mideast policy to the outcomes of elections in Israel. The dramatic progress in the peace process since 1993, officials [in Washington] fear, will be jeopardized if Shimon Peres is not returned to the office." 235

Prior to the vote Clinton had tried to bolster Peres's image by bringing attention to the positive ties between Washington and Jerusalem under the Labor Party during the past four years. In fact, three weeks before the election Clinton hosted Peres and the two signed enhanced cooperation agreements, one in high-tech defense and the other in counter-terrorism. $^{236}$

So it is not surprising that Binyamin Netanyahu's surprising and narrow defeat of Shimon Peres disappointed Washington and brought familiar strains from the Shamir years - amidst the most serious and comprehensive peace effort to date, and one which

\footnotetext{
${ }^{235}$ James D. Besser. "Too Close For Comfort: The Clinton administration's embrace for Peres elicits cries of meddling and backlash fears if Netanyahu prevails." The Baltimore Jewish Times. 17 May 1996, p. 40.

${ }^{236}$ Ibid, p. 40.
} 
increasingly relied on U.S. guidance and supervision. ${ }^{237}$ That would put much of American Jewish leadership back on a defensive posture. Many mainstream leaders who supported Oslo's "land for peace" formula were now caught between their own sentiments of the need for a strong U.S. role in ushering the peace process forward, and a new Israeli administration seemingly more interested in slowing down the talks and supporting the settlement rights of Jews in the West Bank, Gaza Strip and on the Golan Heights. $^{238}$

From the start, American leaders were suspicious of Netanyahu. In her memoirs, Secretary of State Madeleine Albright refers to him as "both disarming and somewhat disingenuous" because "we would think we had reached an understanding and were moving toward an agreement, only to find that that wasn't his intention at all.,"239 Likewise, President Clinton diplomatically hinted at his distaste for Netanyahu by writing that the Israeli's victory came "with the help of a Republican media advisor ... I thought Shimon [Peres] had done a good job as prime minister ... but in 1996, by a narrow margin, Netanyahu had proved a better politician."240

\footnotetext{
${ }^{237}$ Alison Mitchell, "The Israeli Vote: The Policy: Clinton Is Shaken, But Reaffirms Tie," New York Times. 31 May 1996.

${ }^{238}$ David Stout, "The Israeli Vote: In America: In Reactions, Jewish Groups Echo the Split Of the Results." New York Times. 1 June 1996. Even AIPAC issued what the newspaper called a "terse statement congratulating Mr. Netanyahu and expressing the hope that relations between the United States and Israel would continue to be close." Gail Pressberg of Americans for Peace Now was much more blunt: "We're worried," she said.

${ }^{239}$ Madeleine Albright, Madam Secretary: A Memoir. (New York: Miramax Books, 2003), p. 375.

${ }^{240}$ Bill Clinton, My Life. (New York: Vintage Books, 2004), p. 714. For the diplomatic dances with Washington during Netanyahu's first U.S. trip as premier, see Steven Erlanger, "Netanyahu Airs Differences With Clinton On Peace Issues," New York Times. 10 July 1996. The adviser was the New York City-based Arthur Finkelstein, whom Netanyahu also used in the 1999 elections.
} 
Much to Clinton's chagrin, Netanyahu's strong knowledge of American culture and the U.S. political system gave the new prime minister a great advantage in opposing the White House. In fact, when elected in 1996, he had such knowledge of the ways of the United States that The New York Times dubbed him "the 'American premier." 241 Unlike his Likud predecessor Yitzhak Shamir, Netanyahu was fluent in idiomatic English, counted leading influential American Jews and non-Jews as personal friends, and understood the opportunity that a Republican Congress presented in going against a Democratic administration. All of this was highly useful to the Israeli, who had lived as a teen and young adult in the United States, but certainly not in ways that all American Jews and their political allies always appreciated. ${ }^{242}$ The Israeli leader indeed showed savvy in cultivating both the Republican leadership of the U.S. Congress and the influential Christian right as a counterbalance to pressure from the Clinton administration. The latter wanted Netanyahu to continue moving ahead with the "land for peace" process of the Rabin-Peres years. Netanyahu, however, countered that there had been land given, but no peace as Palestinian terrorists kept up with their suicide bombing campaign and Arafat refused to rein them in. He was demanding "reciprocity," by which he meant that without the Palestinian Authority acting against the radicals in its midst particularly followers of Hamas - as well as stopping anti-Israel/anti-Jewish incitement,

\footnotetext{
${ }^{241}$ Serge Schmemann, “The Israeli Vote: Man In The News: The 'American' Premier,” New York Times, 1 June 1996.

${ }^{242}$ At age 14, Netanyahu moved with his family to a suburb of Philadelphia; his father taught both in that area and at Cornell University. After graduating high school and returning to Israel to serve in the army, Netanyahu came back to the United States where he enrolled in MIT and received a Master's of Business Administration. He then became a furniture company's marketing director for a few years, before being tapped in 1982 to be Israel's Deputy Chief of Mission at its Washington embassy, which launched his diplomatic/political career.
} 
Israel would not feel bound to fulfill its obligations, particularly when it came to curtailing settlement building and enabling greater Palestinian freedom of movement.

Still, as the leader of an important U.S. ally, Netanyahu was warmly welcomed in Washington on his first trip as prime minister. In fact, as did his two immediate predecessors, on July 10, 1996, he addressed a joint session of Congress. In doing so, he fully employed his fluency in "American-speak" while offering the message, according to American Jewish Committee head David Harris that “I'm someone you can work with, who knows you and admires you" but "I can be uncompromising in my principles and successful in presenting my case and furthering Israel's cause.” He gained more appreciation from the cost-cutting minded Republican lawmakers when he declared:

There can be no greater tribute to America's long-standing economic aid to Israel than for us to be able to say: We are going to achieve economic independence... In the next four years, we will begin the long-term process of gradually reducing the level of your generous economic assistance to Israel. I am convinced that our economic policies will lay the foundation for total self-reliance and great economic strength. ${ }^{243}$

Meanwhile, the Republican-led Congress, not necessarily acting at Netanyahu's behest but certainly in part to harass President Clinton, had already been dissenting on the particulars of future U.S. involvement in insuring a Mideast peace. A prime example came in May 1998 at its leadership's negative response to the potential use of U.S. troops

\footnotetext{
${ }^{243}$ Steven Erlanger, "In Netanyahu, Congress Sees Familiar Spin.” New York Times. 11 July 1996. Also see “Address by Prime Minister Netanyahu to a joint session of the U.S. Congress, 10 July 1996." Netanyahu had Finance Minister Yaacov Neeman craft a 10-year phasing out of U.S. economic aid to Israel while subsequently increasing military aid, although to a level lower than the previous combined military and economic aid.
} 
being stationed on the Golan Heights to monitor a much hoped for - and at the time seemingly possible -- future Israel-Syria accord. ${ }^{244}$

Further, as is often the case, domestic politics thrust their proverbial creation of strange bedfellows into the equation. On May 8, 1995, GOP presumptive presidential nominee and Senate majority leader Robert Dole (R-Kansas), a former critic of Israel, introduced the Jerusalem Embassy Relocation Implementation Act, which had overwhelming support from American Jewry. ${ }^{245}$ It passed on October 23, 1995, by a 93-5 vote in the Senate; a parallel measure gained an equally impressive $374-37$ vote in the House of Representatives. The new statute declared that the U.S. embassy in Israel sitting near the Tel Aviv beach since the state's independence in 1948 - must be moved to Jerusalem. President Clinton signed the bill, which was toothless as it included a waiver that the shift could be deferred if the president felt it in the best interest of national security (a case every president since has made). ${ }^{246}$

\footnotetext{
${ }^{244}$ Neil Rubin, "Newt And Us: Where the Speaker Stands With Jews." Baltimore Jewish Times, 5 May 1995, p. 51. When asked about U.S. troops on the Golan Heights, Newt Gingrich, newly-elected Speaker of the U.S. House of Representatives, said, "I wouldn't close the door, but I'm very skeptical." He detailed the differences between the U.S.-led multi-national force in the Sinai that monitored the 1979 Israel-Egyptian peace treaty and the proposed Golan force. Ever the student of European history, he added, "I don't want to get into a British commitment to Poland and Belgium in 1914 when they couldn't or didn't honor their treaties." Republicans had captured the U.S. House in the 1994 mid-term elections. Gingrich had long been a favorite of Israel advocates.

${ }^{245}$ Katharine Q. Seelye, "Relocating Embassy in Israel: Move Could Backfire on Dole." New York Times. 18 May 1995. The U.S. embassy continued (and as of this writing continues) to be located in Tel Aviv, along with nearly every other embassy, despite Israel's long-standing declaration that Jerusalem was its capital city. Most governments felt that moving their diplomatic staff to Jerusalem would unnecessarily aggravate Arab states.

${ }^{246}$ Matthew A. Berger, “Jewish Groups Not Surprised Bush Won’t Move Embassy.” Jewish Telegraphic Agency, 12 June 2001. Both the Clinton and George W. Bush administrations decided that moving the embassy would inflame Arab sentiments against the United States, which would harm national security interests.
} 
Nonetheless, despite Republican negativism, with substantial U.S. assistance there were steps forward in the peace process during Netanyahu's tenure. These advances revealed how - unlike in the original Oslo agreement - the United States had become now the major steward of the peace process. Indeed, only with heavy U.S. prodding did the two major agreements of the Netanyahu years get signed -- the Hebron Protocol and the Wye Accord (both ostensibly being detailed plans to implement Oslo II).

The Hebron Accord (formally the Protocol Concerning the Redeployment in Hebron) came about because upon coming into office Netanyahu was left by Peres with the need to implement a future West Bank withdrawal; Peres did not have time to accomplish this during his short tenure due to distractions such as the election campaign and the 1996 Operation Grapes of Wrath against Hezbollah forces in southern Lebanon. This was no simple matter as Hebron, a large city in West Bank terms, was an extremely important venue for Palestinians and had been left out of the original Oslo II agreements in large part due to the presence of 400 radical Israeli settlers in its center. In addition to being the base of some of the most radical Palestinian terrorists, the city's history stretched to biblical times and contained the traditional burial tomb of Jewish patriarchs and matriarchs, figures also sacred in Islam. As such, both Jews and Arabs prayed at the same structure, the machpelah. ${ }^{247}$ Meanwhile, the small Jewish settlement in Hebron's center was always considered one of the more radical Jewish outposts in the West Bank.

\footnotetext{
${ }^{247}$ The machpelah also was the scene of the 1994 massacre of Muslims at prayer, an act perpetuated by Israeli settler Baruch Goldstein, who was subsequently beaten to death by Palestinians. At the time, revealing the intense emotional tinder box of Hebron, in response Rabin considered evacuating Hebron's Jewish settlers to the Kiryat Arba settlement just outside of the city. He elected not to do so because of concerns that the move would spark violent resistance. Dennis Ross, The Missing Peace: The Inside Story of the Fight for Middle East Peace. (New York: Farrar, Straus And Giroux, 2004), pp. 126-127. Instead, a "temporary" international monitoring force was placed in the city.
} 
The nationalist Netanyahu was steeped in the "Greater Israel" philosophy of his Zionist revisionist political ideological upbringing. He clearly had no desire to pullout from a city not only religiously important, but also the scene of a well-remembered, bloody massacre of Jewish residents during the 1929 Arab uprising; that incident was long part of the nationalist lore of his right-wing supporters. Yet, after substantial U.S. involvement, particularly by U.S. negotiator Dennis Ross, on January 15, 1997, he signed the Hebron Protocol. Its provisions included Israel handing over 80 percent of the city to the Palestinians (meaning military and civilian), but leaving the 400 hardcore Jewish settler families to remain in an Israeli-guarded enclave in the city's center. ${ }^{248}$

With the implementation of a further Israeli withdrawal from more of the West Bank bogged down by the Fall of 1998, both Arafat and Netanyahu accepted a U.S. invitation to come to a retreat center on Maryland's Eastern Shore. In some regards it was a welcome distraction for Clinton, who was being battered in the media both by the Monica Lewinsky scandal's fallout and the Republican-controlled Congress calling for his impeachment for allegedly lying under oath about his relationship with Lewinsky. ${ }^{249}$

There, from October 15-23 at the Aspen Institute on the Wye River, under President Clinton's personal guidance they hammered out an accord that would hopefully

\footnotetext{
${ }^{248}$ The full text is at: <http://www.mfa.gov.il/MFA/Peace+Process/Guide+to+the+Peace+Process/Protocol+Concerning+the+Re deployment+in+Hebron.htm>. The detailed agreement specifies security coordination between the two sides. For more on the U.S. role in crafting the accord, see William B. Quandt, Peace Process: American Diplomacy and the Arab-Israeli Conflict Since 1967. (Washington, D.C., Berkeley and Los Angeles: Brookings Institution Press and University of California Press, 2001), pp. 344-347. Also, see Ross, pp. 268322 .

${ }^{249}$ Clinton actually was impeached by the House of Representatives on December 19, 1998. On February 12, 1999, the U.S. Senate declined to charge him with perjury. See Clinton, pp. 834-842, 845.
} 
get the troubled peace process back on track. ${ }^{250} \mathrm{~A}$ dramatic last minute appearance by Jordan's ailing King Hussein, who literally rose from his hospital bed where he was being treated for late stage cancer, helped bring the deal to fruition.

Still, even that success provided the seemingly omni-present last minute crisis between Netanyahu and Clinton. This time it came in the reappearance of the Pollard affair. Jonathan J. Pollard, a U.S. Navy civilian intelligence employee, had been caught in late 1985 spying for Israel and eventually received a life sentence. ${ }^{251}$ Netanyahu, hoping to score points with his right-wing constituency, which he knew would oppose Wye's further withdrawals, lobbied the Clinton administration to have the American spy released into his custody as a payoff for signing the Wye River Accord. Clinton reportedly at first agreed, but then backed down after the strong objection of the U.S. intelligence community, including the threatened resignation of CIA Director George Tenet. $^{252}$

The U.S. spy chief's support was important as the CIA became increasingly involved in the Mideast peace process, including setting up a committee to monitor terrorism, training Arafat's forces, and setting up an Israeli-Palestinian-U.S. committee

\footnotetext{
250 "Israel and Palestinian Authority: Wye River Memorandum," in The Israel-Arab Reader: A Documentary History of the Middle East Conflict. (New York: Penguin Books, 2008), pp. 529-534. Eds. Walter Laqueur and Barry Rubin. For details on the Wye talks, see Ross, pp. 414-459.

${ }^{251}$ For an extensive retelling of the Pollard saga, see Wolf Blitzer, Territory Of Lies: The Fascinating Inside Story of Israel's All-American Spy. (Harper \& Row Publishers, Inc.: 1989). For how the Pollard affair rose and fell in the American Jewish consciousness, see James D. Besser, "A Reflection Of Our Insecurities." Baltimore Jewish Times, 26 July 2002, pp. 32-35.

${ }^{252}$ Clinton, pp. 818-819. Clinton agreed to review Pollard's status, but gave no commitment to his release. Pollard remains incarcerated as of this writing. Also see George Tenet with Bill Harlow, At The Center of the Storm. (New York: Harper, 2008), pp. 66-68, 70-71.
} 
on arms smuggling and incitement. ${ }^{253}$ At Wye, Tenet was called in to perform a diplomatic role by negotiating with the Israelis and the Palestinians their security protocols, which would include CIA oversight. After the Israelis and Palestinians developed a joint 30-day plan to enhance security, the American agency would host biweekly meetings with the two sides to assess the implementation of the plan. ${ }^{254}$

To help implement the Wye Accord, as well as again visibly display the U.S. commitment to the process to both Israelis and Palestinians, President Clinton made an historic visit to Gaza City on January 14, 1998 - the first by a U.S. president. There he personally witnessed the Palestinian Legislative Council's voice vote that revoked clauses in its charter calling for the destruction of the Jewish State of Israel. Clinton pressing his case to the Palestinians of the progress the negotiations were bringing them also cut the ribbon to open the new Palestinian airport, an important symbol of national independence. $^{255}$

Yet, Israeli Jews and their U.S. supporters easily found something to criticize on the trip. That came when First Lady Hillary Clinton awkwardly stood silent at another ceremony in which Arafat's spouse, Suha, in Arabic accused Israel of crimes such as poisoning Palestinian drinking water. Anti-peace process advocates used this as proof

\footnotetext{
${ }^{253}$ The CIA had already become integral to the implementation of the Oslo Accords. Since the establishment of the PA, the CIA had trained some key PA forces, including snipers, police, and intelligence officers. The CIA even held joint military exercise with Palestinian units and helped build the West Bank headquarters of the Palestinian anti-terrorism unit. Barry and Judith Colp Rubin. Yasir Arafat: A Political Biography. (Oxford, England: Oxford University Press, 2003), p. 172.

${ }^{254}$ Tenet, p. 65. For Tenet's take on the Wye talks, see pp. 59-72.

${ }^{255}$ For details on Clinton's three days in the region, see Ross, pp. 483-490.
} 
that the Clintons favored a Palestinian state, which even Rabin never publicly supported. $^{256}$

\section{IV.2 The Syrian Track}

Meanwhile, despite extensive efforts by both of Clinton's secretaries of state, Warren Christopher and Madeleine Albright, negotiations on the Syrian track never reached fruition. However, unlike the self-negotiated Israel-PLO Oslo Accords, from the start Israel knew that it would need U.S. intervention to deal with the cautious and intractable Syrian President Hafez Assad. Indeed, even as the Oslo Accord was heading into its final days of preparation - with the U.S. still unaware of its scope - Rabin asked U.S. Secretary of State Warren Christopher to take a question to Assad in Damascus: What would Syria do for Israel in exchange for a full Israeli withdrawal from the Golan Heights? What would the nature of peace between the two countries entail ${ }^{257}$

After the Oslo Accord in 1993, and then the Israeli-Jordanian peace treaty in 1994, the following year seemed as if it might be the one in which an Israeli-Syrian agreement could be signed. From December 27-29, 1995, the Wye River retreat center at the Aspen Institute served as the site of the first face-to-face negotiations between the two countries since their 1949 Rhodes Armistice talks (the Madrid process having been structured around multi-lateral negotiations). A second round of discussions took place through February 1996, after which the Israelis went home to focus on their pending

\footnotetext{
${ }^{256}$ Hillary Clinton subsequently made several other pro-Palestinian state comments, which some anti-Oslo advocates saw as a trial balloon for her husband. Barry Rubin, "The U.S. In The Middle East, 1998."

Middle East Review of International Affairs. Web. 23 June 2009. Also see Ross, pp. 388-389.

${ }^{257}$ Warren Christopher, Chances Of A Lifetime: A Memoir. (New York: Scribner, 2001), pp. 220-222.
} 
elections, which they and the Clinton administration expected Shimon Peres to win. However, there would be no renewal of talks as four suicide bombings within a few weeks hit Israel beginning on February 25, 1996. Both the Israelis and the Americans asked the Syrians to publicly offer condolences, which would be conducive to resuming peace talks. Nonetheless, there would be no sympathy from Damascus. ${ }^{258}$ A Summit of the Peacemakers, held in Sharm el-Sheikh, Egypt would come on March 13, 1996 as a last ditch effort to regain the momentum for Peres's government. Shortly after that, however, the shaky Hezbollah-Israel truce on the Israeli-Lebanese border fell apart, which resulted in the U.S. having to turn its diplomatic skills into keeping a low-scale conflict from turning into a larger war. By now, despite Peres's military response with Operation Grapes of Wrath, the Israeli electorate had lost confidence in him. ${ }^{259}$

By the time Binyamin Netanyahu was elected Israel's prime minister in late May 1996, Dennis Ross, the Clinton White House's chief Mideast negotiator, thought that the Syrian front in the peace process was dead. ${ }^{260}$ However, Netanyahu was to surprise both fellow Israelis and the Americans with his ongoing secret negotiations with Syria. The messenger was none other than U.S. Jewish leader Ronald Lauder, who in the late 1990s was serving both as the President of the Jewish National Fund and chair of the President's Conference. Shutting out the Americans entirely in the peace process for the first time since the Oslo Accords began, Netanyahu made the Lauder-Assad talks

\footnotetext{
${ }^{258}$ Ross, p. 244. Revealing the linked difficulties of the peace process, the Damascus-based Islamic Jihad took credit for the first bombing in Tel Aviv. Thus, Syria would have been criticizing a group that it supported.

${ }^{259}$ Ibid, pp. 246-254.

${ }^{260}$ Ibid, p. 244. Ross felt that if Peres had been elected, there would have been an Israeli-Syrian deal within a year.
} 
contingent on neither Israel nor Syria informing the Clinton administration about them. ${ }^{261}$ (This differs from the Oslo talks in that while the U.S. government was informed about that earlier dialogue, it was not aware of their scope and progress.)

This was not the first time that U.S. Jews as individuals or a group were understood as an important factor by either Israelis or Americans. In fact, on October 6, 1994 - when optimism remained strong about progress on the Israeli-Syrian front Assad had let his Foreign Minister meet in Washington with Jewish leaders of the Presidents Conference, sending the message that his boss in Damascus had made a "strategic commitment to peace."262

During this period, Clinton put his prestige on the line in personal meetings with Assad, two in Damascus and one in Geneva. The successive decline in optimism of the three gatherings spoke much about Assad's relationship with Israel and the United States. At the first one, in Geneva on January 16, 1994, the U.S. would not give into the Syrian demand to improve full relations between the two countries if Damascus did not give up support for terror groups - which it would not. However, Assad did say that peace with Israel would be "comprehensive" with other Arab states and that Syria's peace with Israel would entail "normal peaceful relations." 263 As Christopher wrote of the next meeting on October 27, 1994, Assad's failure to publicly deliver a promised denunciation of

\footnotetext{
${ }^{261}$ Indyk, p. 246. Netanyahu decided after his defeat that Lauder should brief Barak. For his part, Barak then told Lauder to brief Clinton, which began a diplomatic tussle between Assad, Barak and Clinton over to what both Netanyahu and previously Rabin had agreed.

262 “World News Briefs: Syrian Foreign Minister Meets American Jews,” New York Times. 7 October 1994.

263 Martin Indyk, Innocents Abroad: An Intimate History of American Peace Diplomacy in the Middle East. (New York: Simon \& Schuster, 2009), pp. 104-106. Syria was and of this writing is listed as a statesponsor of terror by the U.S. Department of State due to the presence in Damascus of the political offices of Hamas and other Islamic radical fundamentalists devoted to the State of Israel's destruction.
} 
terrorism (after terrorists had recently struck in Israel) "was beyond disappointing.,"264

Clinton would have one more meeting with Assad, this one on March 26, 2000 in

Geneva. This had come after the failed late 1999 Israeli-Syrian talks in Shephardstown, West, Virginia. ${ }^{265}$ The final Clinton-Assad meeting went so poorly that at one point the U.S. president told his translator, "What's the point? He's not listening." Clinton had tried in vain to have Assad accept Israeli proposals for dealing with regaining the June 4, 1967 border. The problem in part was Israel's returning the northeastern corner of the Sea of Galilee and the immediate adjacent land to Syria would again put Syrian troops significantly closer to Israeli population centers without the protective slopes of the Golan Heights. ${ }^{266}$

\section{IV.3 Netanyahu, American Jews and the Conversion Crisis}

Reflecting their general sentiment of supporting the Jewish state's democratically elected government, Netanyahu actually came to power with a higher level of approval amongst American Jews than those of Israeli voters. The latter had given him the smallest margin of victory in the nation's first direct vote for prime minister - a 50.1 to 49.9

percent victory over Peres. ${ }^{267}$ By contrast, according to a poll by the U.S.-based and pro-

\footnotetext{
${ }^{264}$ Ibid, p. 223.

${ }^{265}$ For a detailed description of the talks, see Ross, pp. 540-565.

${ }^{266}$ Indyk, pp. 273-276.

${ }^{267}$ Prior to the 1996 elections, Israelis only voted for political parties. Then the leader of the party with the most votes, and the one most likely to form a governing coalition, was tapped by the country's president (a largely ceremonial post) to form a government. In 1996 and 1999, Israelis had a split ballot, voting for both parties and prime ministerial candidates. The new system, which created an even more fractured Knesset due to the rise in small parties, was abandoned after those two ballots.
} 
peace process Israel Policy Forum (not a Netanyahu supporter), 62 percent of American Jews had a favorable view of the new prime minister and 85 percent felt that he would continue the peace process, albeit it at a slower pace. ${ }^{268}$

Meanwhile, American Jewish critics of the peace process were clearly emboldened by Netanyahu's triumph. When the prime minister addressed the President's Conference in New York City in July, loud hissing greeted the head of Americans for Peace Now when he asked about Palestinian national aspirations, and sustained applause greeted Netanyahu's response that he was more concerned with "the national aspirations of Jews." ${ }^{269}$ Likewise, upon his election the modern Orthodox activist leader Rabbi Avi Weiss declared, "It's only a Likud government that will be able to secure this peace."270

Yet, Netanyahu's tenure also saw the greatest sustained period of tensions to date between American Jews and an Israeli government. Despite Netanyahu's professed desires to keep the religious status quo, his Orthodox coalition partners were clear in cementing their influence on matters of personal status. So it was that as the peace process hemmed and hawed, and American Jews mirrored Israelis in showing an overall decline of support for the Oslo process, Netanyahu's domestic policies were bringing the most opposition from American Jews.

\footnotetext{
${ }^{268}$ Lawrence Grossman, “American Jewish Communal Affairs.” American Jewish Yearbook 1998 (New York and Philadelphia: The American Jewish Committee and The Jewish Publication Society, 1998), p. 109. While 59 percent of American Jews said they would have voted for Peres, their positive view of Netanyahu reflects their general support of any elected Israeli government, particularly at the start of its term.

${ }^{269}$ Ibid, pp. 108-109. For more on Netanyahu's trip and his interaction with American Jews, see N.R. Kleinfield, "Netanyahu, in New York, Promotes His Views on Peace and Invites Investments," New York Times. 12 July 1996.

${ }^{270}$ Ibid, p. 109. It's interesting to note that Weiss seemed to take it for granted that the peace process would continue and eventually result in an agreement.
} 
Such a development should have been no surprise. When Netanyahu came to power, his governing coalition of 66 Knesset seats included the largest showing of Israel's Orthodox parties in the country's history. The 23 members of Orthodox political parties included Shas (10), National Religious Party (9), and United Torah Judaism (4). No one was shocked that the promotion of Jewish religion - in this case an Orthodox interpretation of it - was an important domestic agenda item for these parties.

American Jews were given an early hint of Netanyahu's priorities. In September 1996, during a visit to the United States, his tight schedule did not allow the typical round of meetings with American Jewish leaders. However, he did have time to visit the grave of the late Hasidic leader the Lubavitcher Rebbe Menachem Mendel Schneerson, whose Israeli followers had voted for Netanyahu coalition partner United Torah Judaism. ${ }^{271}$

Then what became known as the "conversion crisis" erupted. In keeping with a campaign promise to the religious sector, Netanyahu moved to solidify Israel's "Who Is A Jew?" law. Until now, on a de facto basis it meant that in Israel only the conversions of Orthodox rabbis would be accepted, but that any such event outside of the Jewish state by any rabbi of any denomination would be acceptable in Israel. Thus, if someone was converted by a Reform rabbi in the United States, that person could make aliyah as a Jew. The Orthodox parties wanted to change this to validate Orthodox conversions only. Such a conversion, however, was not desirable by some converts to Judaism as it involved a rigorous process of study with an Orthodox rabbi for at least one year as well as being

\footnotetext{
${ }^{271}$ Grossman, “American Jewish Communal Affairs,” 1998, pp. 133-134. In Israel the Lubavitch
} movement is simply known as Chabad. It is formally known, however, as Chabad Lubavitch. 
shomer mitzvot, or observant according to Orthodox law - keeping strictly kosher, not violating Shabbat provisions, observing all minor and major holidays, etc. ${ }^{272}$

Making the issue even more controversial was the fact that from 1989 to 2001 the State of Israel was in the process of absorbing what would eventually be more than 1 million Soviet immigrants; at least one quarter of the immigrants, according to the Ministry of Absorption, were not considered Jewish according to an Orthodox interpretation of Jewish law. ${ }^{273}$

On the other side of the Atlantic Ocean, non-Orthodox American Jews were outraged. After all, about 90 percent of were not Orthodox. Thus, whether they were affiliated with a synagogue or not at the moment, some saw this as invalidating their own religious beliefs. A tweaking of the law, some feared, would alienate American Jews from supporting Israel at a time when Jewish political power and financial assistance to the Jewish federation movement was needed most. Leaders of the United Jewish Appeals - the umbrella federation movement (in 1999 renamed the United Jewish Communities and since November 2009 the Jewish Communities of North America) recognized the problem. They urged U.S. Jewish denominational leaders to sign a letter asking people to

${ }^{272}$ Peres dealt with this issue, too, in the wake of the Rabin assassination as he tried to reach out to the Orthodox political parties to support the Oslo process. Only one week after formally forming his government, Peres met with Israel's two chief rabbis and announced he would form a cabinet committee under the Justice Minister to seek a solution to the conversion issue. David Landau, "U.S.-Jewish Groups Battle Orthodox-Only Conversion Law," Jewish Telegraphic Agency, 1 December 1995.

For the context in which Netanyahu dealt with the issue, see David Horovitz, Leslie Susser, and Vince Beisser, "Who'll Be A Jew?" Jerusalem Report, 12 December 1996, pp. 12-16. For Shamir's dealing with the topic, see Thomas L. Friedman, "Israelis Bar Redefining Of A Jew, Posing Threat To Rule By Shamir," New York Times, 9 July 1987, and Joel Brinkley, "Shamir Promises New Definition of Who Is A Jew," New York Times, 12 November 1988.

${ }^{273}$ Etta Bick. "Sectarian Party Politics in Israel: The Case of Yisrael Ba'Aliya, the Russian Immigrant Party," in Israel At the Polls 1996. Eds. Daniel J. Elazar and Shmuel Sandler. (London: Frank Cass, 1998), p. 136, citing Haaretz, 9 June 1996. 
continue their charitable contributions and not make their philanthropy hostage to political matters. Yet, some key Reform, Conservative and Reconstructionist rabbis would not agree to this. As a result, when Rosh Hashanah arrived in the fall of 1996, at least one dozen Reform rabbis asked congregants to donate funds to Reform institutions in Israel in lieu of the UJA. Numerous others asked for a reduction in UJA donations, with the rest going to Israeli Reform operations. ${ }^{274}$

Also raising concern in the United States were reports of harassment by Israeli Orthodox Jews toward Israeli and American Reform and Conservative Jews praying in mixed gender groups in the Western Wall area during the late spring holiday of Shavuot. ${ }^{275}$

In mid-November, 1997 at the UJA General Assembly, delegates - over the protest of U.S. Orthodox groups - passed a resolution urging Israel not to "change the current situation regarding recognition of conversions' either in Israel or elsewhere.” In a satellite address to the delegates, Netanyahu stuck by his understanding that the acceptance of conversions outside of Israel would not change, but Orthodox ones only were likely in Israel. ${ }^{276}$ That brought a series of delegations of American Jews to Israel to argue one way or another as the topic dominated the Israel-Diaspora relationship.

\footnotetext{
${ }^{274}$ Grossman, "American Jewish Communal Affairs," 1998, pp. 117-118. Followers of Reconstructionist Judaism - originally an offshoot of Conservative Judaism and sometimes referred to as the fourth religious stream of American Jewish life - were roughly about 1 percent of the U.S. Jewish population during this period, according to numerous Jewish demographic surveys

${ }^{275}$ Larry Derfner. “A Wall Of Support,” Baltimore Jewish Times. 5 June 1998, pp. 36-37. The group, which was protected by Israeli police and mainly comprised of Reform and Conservative activisits, was greeted by ultra-Orthodox Jews with chants of "Nazis" and "Goyim" (non-Jews). A year earlier, they had been dragged off by police "for their own protection." As a result, the previous August, to commemorate the Jewish observance of Tisha B'Av, Israeli police would not even let the group convene.

${ }^{276}$ Grossman, “American Jewish Communal Affairs,” 1998. p. 119.
} 
Finally, on April 1, 1997, the conversion bill passed the first of three required readings in the Knesset. Netanyahu did not help his cause by telling reporters that some Reform and Conservative U.S. Jewish leaders were purposely misleading congregants by saying that the bill would give non-Orthodox Judaism a second-class status. Reform and Conservative leaders, in turn, upset Netanyahu by urging their congregations to not invite Israeli government officials and to withhold speaking invitations from Knesset members who supported the bill. Some, such as Rabbi Ismar Schorsch of the Conservative movement's Jewish Theological Seminary of America, called for the disbanding of Israel's Orthodox-controlled Chief Rabbinate. ${ }^{277}$

Ultimately, this led to the formation of the Ne'eman Commission, chaired by Israeli Finance Minister Ya'acov Ne'eman, a modern Orthodox Jew respected for his intellect and moderation. Prior to Rosh Hashanah in 1997, his commission's proposals were leaked to the press: There would be a joint conversion school representing all the denominations, but the actual conversion would be performed by an Orthodox rabbinical court. $^{278}$ While that joint conversion course actually did begin functioning, it operated at the relatively low rate of converting about 3,000 people a year (less than one percent of those eligible) and continually ran into criticism from Orthodox and non-Orthodox leaders alike. ${ }^{279}$

\footnotetext{
${ }^{277}$ Ibid, p. 122.

${ }^{278}$ Ibid, p. 124. For the text of the Ne'eman proposal, see Ne'eman Report on the Conversion Law. (Jerusalem: The Government of Israel Printing Office, 1998).

${ }^{279}$ For more on the conversion crisis, see: Serge Schmemann, “'Who's a Jew' Puzzle Gets More Tangled," New York Times, 27 January 1998; Schmemann, "Israel's Chief Rabbis Reject Call By Non-Orthodox on Conversion," New York Times, 10 February 1998; Deborah Sontag, "Non-Orthodox Rabbis Win A Court Skirmish in Israel," New York Times, 13 December 1998; Sontag, "Israel's 'Who Is a Jew' Perennial
} 
It is interesting to note here that with the peace process slowly, although far from smoothly, moving forward, this issue had become a rallying cry for Diaspora Jews in their relationship with Israel. Indeed, the notion of a forever embattled Israel that had to focus entirely on existential matters and not domestic ones - including the Jewish nature of the State and its role in the life of Diaspora Jewry - seemed fading fast as American Jews (when interested in Israel) appeared to be more focused on what the Jewishness of the Jewish state would be.

However, despite such concerns by American Jews, Netanyahu knew that it was the voters at home that mattered most. So while wrapping up a U.S. visit with a trip to New York City in September 1997, on a rainy Shabbat morning he skipped the usual police car escort that usually announced his arrival. Instead, the secular prime minister walked from the Stanhope Hotel where he was staying to the Orthodox Congregation Kehilath Jeshurun. Since Orthodox Jews are but 10 percent of the U.S. population - and some who attend Orthodox synagogues drive to services - Netanyahu was clearly playing to the crowd back home.

During his 10-minute remarks, he did try to quell the concerns of the nonOrthodox. On religious matters, he said, "we'll keep the status quo.” At the same time, he continued his theme of urging U.S. Jews to stem their overall slide from Jewish knowledge, telling them to study more Hebrew, bring more focus to Israel education and and Beyond." Institute for Global Jewish Affairs 15 Jan. 2008. 
to ask themselves "What have I done to insure that my children and grandchildren will not only remain Jews, but proud Jews?",280

\section{IV.4 Netanyahu's Addresses To The GA}

One set of signposts that can be used to determine how Netanyahu was interacting with American Jews were his addresses to the Council of Jewish Federation's General Assembly meetings. The annual gathering of up to 5,000 North American Jewish leaders (and some Israeli counterparts) is always seen as a showcase of the concerns and moods of the continent's Jewish community (or at least its organizational leadership). Likewise, the address of the Prime Minister of Israel is always a highly anticipated event that often becomes the buzz of the convention. Netanyahu addressed three General Assemblies. Tracing the structure and content of the speeches reveals a great deal about where Diaspora-Israeli ties as well as Netanyahu's position in the peace process were at the time.

In 1996, only five and a half months after being elected, Netanyahu could not appear in person due to the ongoing and difficult Hebron negotiations. As such, he spoke via a live video hookup. He devoted the first half of his talk to the Hebron talks, offering rallying points for the troops in America. Likewise, he went out of his way to pledge his loyalty to previously signed agreements by the Rabin-Peres administration. He also

\footnotetext{
${ }^{280}$ Rachel L. Swarns, "Netanyahu Stresses Cultural Bonds for Jews in New York and Israel.” New York Times. 14 July 1996.
} 
hammered home his theme of the need of Palestinian reciprocity to their commitments a strong indication that he would take a much stronger stand in this area than Peres did. ${ }^{281}$

The second half of his speech must have been music to the nervously attuned ears of the consensus-focused leadership of the Jewish federation system; he spoke strongly not only about Israel's centrality, but about the themes that united all Jews. In fact, Netanyahu did not avoid the concern of many to whom he was speaking when it came to concerns that non-Orthodox Judaism was being delegitimized by his Orthodox coalition partners. While saying that the status quo of Orthodoxy hegemony of conversions in Israel would remain, he declared:

Let me tell you that we are not going to change anything regarding the Reform or Conservative conversions that are done in the United States and elsewhere in the world... We will adamantly refuse and I will personally stand in the breach if necessary, [to stop] anyone who tries to tamper with the idea that youngsters who are Jews, or [who are] Jews who have converted into Judaism in the United States with Reform or Conservative rabbis would not be recognized as Jews. They will be recognized as Jews. They are recognized as Jews. They can come to Israel and marry as Jews and that will not change. ${ }^{282}$

The next year, with the conversion crisis as its height, Netanyahu personally came to the G.A., then meeting in Indianapolis, Indiana. His second paragraph, following a perfunctory "My fellow Jews, my friends, these are uneasy times in the Middle East...," dove into not the peace process, but the internal turmoil of the Jewish world. As he said,

\footnotetext{
${ }^{281}$ Binyamin Netanyahu. "Address by Prime Minister Netanyahu to the Council of Jewish Federations General Assembly, 15 November 1996,” Seattle, Washington.

${ }^{282}$ Ibid. Nonetheless, as Netanyahu well knew, Jews who were converted outside of Israel by non-Orthodox rabbis nearly universally had difficulty getting married in Israel if they wanted that marriage recognized in the Jewish state. That was particularly important if either the bride or the groom had been born in Israel and considered returning to live in the Jewish state one day. Likewise, Diaspora Jews who wanted to have a wedding in Israel by a member of the Israeli rabbinate had to have approval by a hometown Orthodox rabbi. That hometown rabbi - often not the personal rabbi of the couple - needed to be on a list approved by the Israeli Chief Rabbinate as an acceptable halachic decision maker.
} 
"We, too, are facing a crisis of our own inside the Jewish world." ${ }^{283}$ In this speech, Netanyahu flipped his usual two-themed approach to Diaspora audiences. The standard format had been first focusing on Israel's eternal, difficult quest for peace and then on the need for Jews to unite over Israel's centrality and to invigorate efforts to participate in realizing the dream of building a vibrant Jewish state.

Reflecting the tensions of the moment, and clearly aware that his audience would soon be debating his words, he asserted:

We are going to achieve a historic agreement inside Israel only with your help. And it is to seek your help that I have come here tonight. You are not a third party looking in. You are partners at the table, partners in the common cause of Jewish unity. ${ }^{284}$

Netanyahu basically begged those in front of him to "stop looking at each other as enemies." Finally, he returned to the traditional themes of the need for the Diaspora to combat assimilation - whose continuing results would after all damage Israel as it would reduce U.S. Jewish influence in the American political process. Finally, he briefed his audience on the peace process. ${ }^{285}$ This was the most contentious major speech Netanyahu had given to date to an audience normally offering reflexive support for his country's policies.

The following year, with the G.A. meeting in Jerusalem to celebrate the Jewish state's $50^{\text {th }}$ anniversary, Netanyahu first described the progress - minimal as it may have

\footnotetext{
${ }^{283}$ Benjamin Netanyhahu, "Address by Prime Minister Benjamin Netanyahu at the General Assembly of the American Council of Jewish Federations." 16 November 1997.

${ }^{284}$ Ibid.

${ }^{285}$ Ibid.
} 
been - on the conversion crisis front. He again began, much more confidently than in the previous year, by declaring:

We are all equal members of the same people. There is no such thing as a second class Jew!... We need good will, we need loyalty to our common heritage, and we need a sense of responsibility. This is what we have been trying to do over the last two years, as we tackle theological issues of immense importance for us. ${ }^{286}$

Following that, the Israeli leader spoke of his new definition for the role of the Diaspora in the State of Israel's future. As he said, "The first half-century of our life as a state was devoted to securing the life of the State. I believe that the next half century must be devoted to securing the life of the Jewish people." That would entail, he continued, combating assimilation and intermarriage outside of Israel with renewed emphasis on Jewish education and Hebrew literacy. Not forgetting the classic Zionist theme of the ingathering of the exiles, he also called for "massive aliyah from every country of the Diaspora, including the United States, including Canada." Finally, he thrilled the audience with his historic announcement that the State of Israel would be a partner with the Diaspora in funding efforts to draw American Jews closer to Israel. "You're shocked," he said. "Yes, Israel is going to give money to the Diaspora to help promote Jewish education, Jewish identity, visits of Jewish youngsters to Israel. At the $50^{\text {th }}$ anniversary of the Jewish state, it's time we gave something back." 287

\footnotetext{
${ }^{286}$ Benjamin Netanyahu, "Address by Prime Minister Benjamin Netanyahu to the UJA-CJA General Assembly." 16 November 1998. The Israeli leader was not foolish enough to delve into the incendiary definitions of "Who is a Jew?" which was at the crux of the matter for many in the audience.

${ }^{287}$ Ibid. Netanyahu did not give details. However, eventually the State of Israel, the Jewish Federation system, and the "mega-donors" began funding Taglit-Birthright Israel with each giving $\$ 70$ million for a total of \$210 million to get the program started.
} 
Then and only then did Netanyahu explore the peace process, albeit in much greater generalities than in his past two speeches. For example, he offered a phrase that had become a common theme in his administration: "We want to reach a final peace agreement with the Palestinians. But we are not prepared to give up land only to bolster hostility, encourage terrorism and endanger Israel's security." ${ }^{, 288}$ (It is interesting to note that at least publicly Netanyahu was saying that under certain conditions he would give more land to the Palestinians. Whether his definition of those conditions could be met is a matter for debate.)

\section{IV.5 American Jewish, American Catholic Ties Grow}

An often overlooked positive byproduct of the Oslo process was the continuing advancement of interfaith ties, particularly between American Jews and the Catholic Church. One major aid in moving this relationship forward came at midnight on December 31, 1994 when the Vatican established ties with the State of Israel. ${ }^{289}$ Since American Jews were the largest and most organized of Diaspora Jewish communities, they would often, in partnership with Catholic counterparts, visit the Vatican and have ongoing contact with the Holy See's officials regarding Israel and other matters of mutual concern.

The importance of this formal recognition should not be underestimated. As Baltimore's Archbishop Cardinal William H. Keeler - Pope John Paul II's interfaith

\footnotetext{
${ }^{288}$ Ibid. This was before the Wye River agreement, which caused the collapse of Netanyahu's coalition.

${ }^{289}$ The full text of the accord establishing diplomatic relations between Israel and the Holy See is at <http://www.mfa.gov.il/MFA/MFAArchive/1990_1999/1993/12/Fundamental+Agreement+-+IsraelHoly+See.htm>. Web. 30 June 2009.
} 
affairs point person in the United States - said in the months leading up to the diplomatic recognition, many Catholic-Jewish dialogue veterans - "especially in the Jewish community" - see the ties "as the only issue."290 For Jews in the dialogue, the importance of the event was self-evident. With more than one billion Catholics in the world, the Church (as now) was growing mostly quickly in Africa, Asia and South America - areas without many Jews and those absent the rich tradition of co-existence that marks most major urban U.S. areas. Thus, formal ties between Israel and the Holy See could both create formal diplomatic Christian channels for world Jewry as it advocates on behalf of the Jewish state, and act as a bulwark against any residual past Christian theological rejection of the State of Israel and the Jewish people.

In addition, the normalization of ties paved the way for the heralded spring 2000 visit to the State of Israel by Pope John Paul II. While there, he went to a Palestinian refugee camp, met with PA head Yasser Arafat, had an emotional visit to the Yad VaShem Holocaust Remembrance and Martyrs Museum, prayed at the Western Wall, and met Israel's chief rabbis in their offices (a significant display of respect). As IsraeliAmerican philosopher Rabbi David Hartman said, the pontiff came to Jerusalem "not just to visit holy sites but to acknowledge the Jewish people in its homeland. We are no longer a cursed people. We are no more a wandering people. This is a major revolution in Christian thought.",291

However, reflecting the deepening split of intra-Jewish thought on the peace process, not all Jews welcomed Vatican moves into the Israeli-Palestinian conflict.

\footnotetext{
${ }^{290}$ Arthur Magida, “A New Day For Interfaith Talks?” Baltimore Jewish Times, 18 October 1993, p. 46.

${ }^{291}$ Moshe Aumann, Conflict \& Connection:The Jewish-Christian-Israeli Triangle. (Jerusalem: Geffen Books, 2003), p. 66.
} 
Indeed, in February 2000 - already amidst the heated atmosphere of the second intifadah

-- the OU denounced the Vatican-P.A. pact on Jerusalem as "an attempt by the Vatican to inappropriately influence the peace process" by attempting to "redefine Jerusalem as an 'international city.'” Other Jewish groups, however, mostly remained silent on that particular matter. $^{292}$

\section{IV.6 Strains With Mainstream Protestants}

Due to their scope and diversity, U.S. Christian groups have never been as close to uniform in their approach to their baseline support for the State of Israel as have their American Jewish counterparts (specific policy differences amongst Jews not withstanding). As such, despite the growing interfaith dialogue of the 1990s, there were worrisome trends emerging when it came to the Israeli policy of many "mainline" Protestant groups ${ }^{293}$ - basically churches that were neither Catholic nor Evangelical. This was all the more troubling to some veteran Jewish activists as they had become accustomed to strong and positive ties with Protestant groups from the 1960s through the 1980s. Indeed, their shared agenda often included fighting for Civil Rights and poverty eradication programs, bolstering church-state separation, favoring public education, and

\footnotetext{
292 “Orthodox Union Criticized Vatican-P.A. Pact On Jerusalem.” Orthodox Union Institute For Public Affairs. 23 February 2000.

${ }^{293}$ Mainline Protestant churches generally take a more liberal view of early Christian text and documents than do Catholics. As such, they treat the works as historical documents open to greater interpretation. Like Roman Catholics, they rely heavily on biblical scholarship. Yet they also are influenced by "liberation theology." While the school of thought began in the Catholic Church in South America in the 1950s, it has spread in influence. It emphasizes Jesus' mission to the poor and downtrodden. The theology is particularly important when sympathizing with the plight of Palestinians, particularly Palestinian Christians. In Jerusalem, liberation theology is promoted by the Sabeel Ecumenical Liberation Theology Center, and particularly its leader, the Rev. Dr. Naim Ateek. For more, see Naim Ateek and Rosemary Radford Ruether, Justice and Only Justice: A Palestinian Theology of Liberation (Maryknoll, N.Y.: Orbis Books, 1989).
} 
seeking to ostracize South Africa's apartheid regime. For Jews, however, the concerns over Israel became increasingly clear in the post-1967 years when, in the eyes of some Christian groups (and the world), the State of Israel shifted from becoming the defiant biblical David to the ugly Philistine Goliath.

This was a rude wakeup call to some American Jewish leaders. While most had good ties with Protestants in the domestic realm, the energized arena of Mideast peace only accentuated differences as seemingly overnight real settlements might be possible. In part, the disconnect also came from secular Jewish agencies interacting with the religious Christian groups. In other words, the Jews spoke in secular language to their boards (and journalists always eager to report the latest), but the Christians spoke as theologians. ${ }^{294}$

In fact, Protestant groups such as Churches for Middle East Peace (CMEP) routinely reminded fellow Christian leaders that they were forsaking the Jesus's commands of justice for the downtrodden were they not pressing the Palestinian cause. For example, under the CMEP banner on March 6, 1995 - at the height of the Oslo process -- Roman Catholic, Protestant and Orthodox Christian leaders released an open letter to President Clinton entitled "Jerusalem: City of Peace." In it, they declared that the administration had failed "to recognize and support Palestinian rights and interests in Jerusalem" and that Mideast peace efforts would be jeopardized if Israel kept insisting on full control of all of Jerusalem. Perhaps further tipping their intent in publicizing the

\footnotetext{
${ }^{294}$ This was despite the presence of some rabbis guiding interfaith affairs for Jewish agencies. From 1973 to 1998, Rabbi Leon Klenicki directed such efforts for the Anti-Defamation League. Likewise, from 1968 to 2000 Rabbi James "Jim" Rudin was an interfaith affairs staffer and then director for the American Jewish Committee. However, both worked for secular organizations and their pronouncements did not have any theological weight.
} 
letter, the document also said that the Christian groups wanted a say in the negotiations because, after all, they too had a theological claim to Jerusalem. ${ }^{295}$

Likewise, on December 21, 1996, CMEP ran a full page advertisement in The New York Times that called on Israel to give up its claim to East Jerusalem, which shortly after the 1967 Six-Day War Israel had annexed as its "undivided capital." The ad even included a coupon for readers to cut out and send to the Senate Foreign Relations Committee; it urged "the concept of a shared Jerusalem," which was code for internationalizing the city, something Israelis resolutely rejected. Those signing included members of the National Council of Churches, a partner for many Jewish groups on separation of religion and state issues. That set into a motion a meeting between the Presidents Conference and the National Council of Churches, which failed to come up with statement of reconciliation on the issue. ${ }^{296}$

Such concerns were not new for individual churches as well. One example had come a dozen years earlier. In June 1987, the Presbyterian Church (USA) -- revealing both its own thinking and the internal strains within Christian America as mainstream Protestant fought to stem the growing membership of Evangelical churches - declared in part:

All, including the State of Israel, stand accountable to God. The State of Israel is a geopolitical entity and is not to be validated theologically... We disavow those views held by some dispensationalists and some Christian Zionists that see the formation of the State of Israel as a signal of the end

\footnotetext{
295 "Jerusalem: City of Peace: A Statement To President Clinton From Christian Leaders," Churches for Middle East Peace, 6 March 1995.

${ }^{296}$ Grossman, “American Jewish Communal Affairs,” 1998, p. 112.
} 
of time, which will bring the Last Judgment, a conflagration that only Christians will survive... ${ }^{297}$

It would take until 2002 - two years into the second intifada - for the ADL to fully acknowledge the problem. That came in a guide for local dialogue on Israel with Christian groups. In the introduction, ADL National Chair Glen A. Tobias and National Director Abraham H. Foxman candidly wrote:

As the Israeli-Palestinian conflict has worsened, the divide between the Jewish people and many Christian leaders has grown, and effective Jewish-Christian communications on the Middle East has decreased. Many churches in the United States have taken positions that are openly pro-Palestinian, paying insufficient attention to legitimate Israeli rights and interests. Due to the lack of ongoing dialogue, Jewish communities are sometimes surprised by these positions and are unprepared to respond effectively. ${ }^{298}$

\section{IV.7 An Evangelical Alliance}

On the other side of the Protestant Christian community, American Jews also seemed unprepared to deal with the pro-Israel Evangelical embrace that greeted them. In fact, Netanyahu's rise to power had revealed the depth of growing support for the Jewish state amongst this group, often referred to as Christian Zionists or Christian conservatives. ${ }^{299}$

\footnotetext{
${ }^{297}$ Aumann, pp. 234-237. In 2004, the Presbyterian Church (USA) would be at the forefront of Christian divestment efforts in the State of Israel as a protest against Israel's treatment of the Palestinians, which would in turn become a major issue for the JCPA and local Jewish community relations councils.

${ }^{298}$ Eugene Korn, Meeting The Challenge: Church Attitudes Toward the Israeli-Palestinian Conflict, (New York: Anti-Defamation League, 2002), p. 2.

${ }^{299}$ Netanyahu was far from the first Israeli leader to court American evangelicals. In 1971, Carl Henry, former editor of Christianity Today, hosted a "prophecy conference" in Jerusalem for 1,500 delegates from 32 countries. Then 85-year-old former Prime Minister David Ben-Gurion greeted the crowd and Golda Meir's Israeli government provided the hall free of charge. Prime Minister Menachem Begin (1977-1983)
} 
Yet most American Jewish leaders were uncomfortable with cultivating such support. That stemmed from a multitude of factors: their historical distrust of a group that sought to proselytize Jews; the Jewish community's heavy Democratic Party support; a tradition of working in urban areas with Catholic and mainstream Protestants; and the absolutist philosophy of the Evangelicals, which would allow no compromise. ${ }^{300}$

But Netanyahu knew well that the Evangelical community was a power base in the American political scene that could help advance his agenda and deflect pressure from the White House. Indeed, it had been rising ever since the Reagan era of the 1980s when Moral Majority leader the Rev. Jerry Falwell became a frequent guest at the Reagan White House. Likewise, the Rev. Pat Robertson - founder of the Christian Broadcasting Network - ran for president on the GOP side in 1988, putting Evangelical ideas into the political mainstream.

In addition, documents of American Evangelical groups had never shied from advocating for Jewish political independence. In 1945, in the immediate shadow of the Holocaust and while Great Britain still tenaciously hung onto its Palestinian mandate, the Evangelical church group Assemblies of God adopted a detailed resolution condemning anti-Semitism that included this language: "Every child of God who finds joy in the

took the relationship to a new level with his friendship of the Rev. Jerry Falwell by buying the Christian leader a Lear jet to fly around the United States to spread the pro-Israel word. This, too, was an issue of concern from many American Jewish leaders who distrusted both Falwell's attempts to back issues such as prayer in public school and the proselytizing of many of his followers.

${ }^{300}$ Laurie Goodstein, "Falwell Offers To Mobilize Churches To Oppose Israeli Pullback," Washington Post, 21 January 1998. Regarding compromises, the evangelicals greeted Netanyahu with chants of "not one inch!" 
revealed will of our Father delights in the glorious promise of Israel's restoration" as an independent Jewish state. $^{301}$

Netanyahu needed political allies in the United States. So throughout his tenure in office, he used the Christian support - sometimes to the dismay of mainstream Jewish groups - as a counterweight to the Clinton administration. The strategy was designed and pushed by Netanyahu's chief political adviser, the American-born David Bar-Ilan. ${ }^{302}$

As but one example, in early 1998 the Israeli leader came to the United States to see President Clinton to discuss Israel's next phased withdrawal from the West Bank. But his first stop in America was neither to confer with congressional supporters nor American Jewish leaders. Rather, he met with 1,000 Evangelical Christians gathered at the behest of the Rev. Jerry Falwell. In a gesture that could not have been to the liking of the Democratic White House, the crowd saluted Netanyahu as "the Ronald Reagan of Israel," the former U.S. President (1981-1989) being an iconic figure for the politically conservative community. For his part, Falwell promised Netanyahu the support of 20,000 evangelical pastors who would "tell President Clinton to refrain from putting pressure on Israel" to adhere to the Oslo Accords. ${ }^{303}$ Then Netanyahu met privately with Falwell and leaders of the Southern Baptist convention. As the American-Israeli journalist Gershom

\footnotetext{
301 Aumann, p. 71.

${ }^{302}$ Gershom Gorenberg, The End Of Days: Fundamentalism and the Struggle for the Temple Mount. (Oxford, England: Oxford University Press, 2000), p. 166.

${ }^{303}$ Donald Wagner, "Evangelicals and Israel: Theological Roots of a Political Alliance," in Christian Century, 4 November 1998, p. 1020.
} 
Gorenberg has written, "as a foreign leader visiting Washington, Netanyahu could hardly have been ruder to his host, the American president." 304

In Israel itself, Evangelical operations such as the International Christian Embassy in Jerusalem were warmly welcomed. Founded in 1980, the operation both served as a base for Christian Zionists visiting the Holy Land and supported their political advocacy for Israel abroad. The groups have raised tens of millions of dollars to bring many thousands of Jews from the former Soviet Union to the Jewish state, had twin community relationships with West Bank Jewish settlements and stood solidly against any territorial concession to the Palestinians. ${ }^{305}$

Sensing the political power and humanitarian assistance such support could bring from so many people (an estimated 60-70 million Americans alone), some American modern Orthodox rabbis - often to the uneasiness of their colleagues - created groups that allied with the Christian Zionists on both international and domestic issues. In the former category was Rabbi Yechiel Eckstein's International Fellowship of Christians and Jews (IFCJ). Founded in 1983, its goal is to foster Evangelical-Jewish ties in general. Yet, it bases its appeal almost entirely on biblical texts (both Jewish and Christian) that promote the humanitarian need to raise funds for Israeli Jews. From 1994 to 2004, Rabbi Eckstein estimated that the group had brought in about $\$ 100$ million to aid the State of Israel's humanitarian needs. ${ }^{306}$ Some Orthodox Jews also sought to further ties with Evangelicals on domestic issues such as favoring vouchers for private schools and

\footnotetext{
${ }^{304}$ Gershom Gorenberg, The End Of Days: Fundamentalism and the Struggle for the Temple Mount. (Oxford, England: Oxford University Press, 2000), p. 162.

${ }^{305}$ Bill Broadway, “The Evangelical-Israeli Connection,” Washington Post. 27 March 2004.

${ }^{306}$ Ibid.
} 
advancing a "morals" agenda including allowing for mandatory moments of prayer (or reflection) in public school. One example of this was Rabbi Daniel Lapin's Toward Tradition, which ties its Jewish-Christian outreach programs to advancing politically conservative ideas. $^{307}$

Still, the perception of anti-Semitism continued to hamper the U. S. JewishChristian relationship in this period (and today). For example, when asked in 1997 if they thought that the "Christian right" was anti-Semitic, 47 percent of American Jews responded either "most" (22 percent) or many (25 percent), meaning that nearly half felt at least many Evangelicals were anti-Semitic. ${ }^{308}$ By 2001 - well into the second intifadah - the distrust rose even higher, despite Evangelicals being in the forefront of defending the Jewish state nationwide. That year, the American Jewish Committee survey reported that 54 percent of American Jews felt that "most" or "many" on the Christian right were anti-Semitic individuals. ${ }^{309}$ While the new intifadah had given rise to a heightened debate amongst Jews regarding pro-Israel Evangelical support, the Evangelical support for now President George W. Bush was greeted with great suspicion by most American Jews, who feared an advance of conservative social policies favored by the Christians.

\footnotetext{
${ }^{307}$ For more on Lapin's thought, see Daniel Lapin, Buried Treasure: Hidden Wisdom From The Hebrew Language. (Waterbrook Multnomah Publishing Group: Colorado Springs, Col., 2001).

${ }^{308} 1997$ Annual Survey of American Jewish Opinion. (New York: American Jewish Committee, 1997), p. 20.

${ }^{309} 2001$ Annual Survey of American Jewish Opinion. (New York: American Jewish Committee, 2001), p. 9. In part, this came from the strong support of then Gov. George W. Bush in his 2000 presidential campaign, in which he made strong outreach to Evangelicals and American Jews overwhelmingly supported Democratic challenger Vice President Al Gore.
} 


\section{IV.8 Shifts In American Jewry's Attachment to Israel}

Netanyahu's move toward U.S. Evangelicals, away from how the vast majority of U.S. Jews saw Jewish pluralism, and tense relationship with the Clinton administration took its toll on American Jewish attachment to Israel. This is revealed when one compares the periodic surveys of American Jewish opinion from the start of Netanyahu's three-year term in office through the 18 months that his successor, Ehud Barak, was in power. The primary sources for this period are the American Jewish Committee's Annual Surveys of American Jewish Opinion.

When analyzing the five surveys that came out just before, during and after Netanyahu's term - 1996, 1997, 1998, 1999, and 2000 - it is clear that while American Jews remained reluctant to criticize Israel in general, they were increasingly willing to do so specifically. For example, each year respondents were asked: "Looking ahead 3 to 5 years, do you see Jews in Israel and in the United States becoming closer, drifting apart, or neither?"

The results were revealing:

\begin{tabular}{lccccc} 
Year & 1996 & 1997 & 1998 & 1999 & 2000 \\
\hline Closer & 34 & 31 & 26 & 31 & 32 \\
Drifting farther apart & 12 & 13 & 19 & 19 & 12 \\
Neither & NA & 54 & 48 & 41 & 50 \\
Not sure & NA & 3 & 4 & 3 & $6^{310}$
\end{tabular}

3101997 Annual Survey of American Jewish Opinion. (New York: American Jewish Committee, 1997), p. 39, 1998 Annual Survey of American Jewish Opinion. (New York: American Jewish Committee, 1998), p. 29, 1999 Annual Survey of American Jewish Opinion. (New York: American Jewish Committee, 1999), p.1, and 2000 Annual Survey of American Jewish Opinion. (New York: American Jewish Committee, 2000), p. 1. Numbers for 1996 come from a comparative chart in the 1999 study which did not list all responses. 
As the conversion crisis began seeping into American Jewish consciousness in 1998 - the study was taken between February and March 1998, meaning a few months after Netanyahu's late 1997 speech at the federation movement's General Assembly American Jews who said they felt that they were becoming "closer" to Israeli Jews fell from 31 percent to 26 percent (an eight point drop from two years earlier). The next year the numbers went back to 31 percent.

Why the drop and subsequent rise? On one level, these numbers can be seen positively as they reveal an overall resiliency to American Jewish-Israeli ties, albeit one that can be dented over a specific issue. Of more concern, however, is that when one looks at the periodic specific relationship questions, such as whether Reform and Conservative conversions should be recognized in Israel on equal par to Orthodox ones, the results directly mirrored the Orthodox/non-Orthodox split in the U.S. Jewish population. That is, 89 percent agreed while 9 percent did not (and two percent were not sure). ${ }^{311}$ Thus, as 26 percent of American Jews felt they were becoming “closer" with their Israeli counterparts, an overwhelming 89 percent rejected the Israeli government's moves into Jewish status issues.

In 1998 the conversion issue had cooled; an apparent compromise was in the works, U.S. Jewish groups were backing off their support for challenges in the Israeli Supreme Court, and the Wye agreement had been signed. This, in fact, was likely Netanyahu's high point in popularity in the United States. Meanwhile, Israel was preparing for another national election and Labor Party challenger (and eventual winner)

3111998 Annual Survey of American Jewish Opinion, p. 33. The following year, the numbers were nearly identical: 88 percent agreed while 9 percent disagreed. Showing the drop in importance of the issue with Netanyahu out of power, the 2000 survey did not even ask the question. 
Ehud Barak made several visits to the United States, which included conversations with American Jewish leaders.

Finally, in this same period Alan Dershowitz, the prominent Harvard University Law School civil rights activist and author wrote the second of his Jewish themed books. In it, he captured the drift apart amongst American and Israeli Jews in an era in which Jews had reached what until then was a peak in American political, financial and social standing:

"Why, after all, should we expect Jews - or Israelis - to have much in common, beyond common enemies, and fears of persecution as Jews?... In the absence of common enemies, Jews have no more in common with each other than do Americans, or Catholics, or Europeans, or Slavs, or Scandanavians." 312

Other data bore out what was not a dislike or disappointment of or about Israel, but a weakening of the relationship's intensity. For example, in 1997 Steven. M. Cohen authored a survey for the Jewish Community Centers Association. In it, 27 percent of American Jews said they were "extremely" or "very" attached to the State of Israel. That was a 10 percent drop from 1988. Meanwhile, 42 percent said they were "somewhat" attached in the later poll, while 25 percent - one in four American Jews - said they were "not attached" to Israel. ${ }^{313}$

At the same time, more American Jews were going to Israel than ever. According to the earlier National Jewish Population Study (NJPS); the overall number had risen

\footnotetext{
${ }^{312}$ Alan Dershowitz, The Vanishing American Jew: In Search of Jewish Identity for the Next Century. (Boston: Little, Brown And Company, 1997), p. 234.

${ }^{313}$ Eisen, p. 56, citing “The Fall of Public Judaism: The 1997 JCCA Survey of American Jews” (unpublished manuscript), p. 24. When one takes into consideration that only about 50 percent of selfidentified Jews are engaged in organized Jewish life at any given time, the 25 percent figure might not be seen as a strong negative, but a base of residual support that could be built upon.
} 
from 27 percent to 35 percent. ${ }^{314}$ However, during the 1990s initiatives to send teenagers and young adults to Israel were on the rise through additional funding from federation scholarships. That corresponded to the federation's emphasis on people-to-people ties with Israel, which included Project Renewal and its successor, Partnership 2000, both being "twin cities" programs between North American Jewish communities and Israeli towns or neighborhoods. Likewise, the founding and strengthening during the 1990s of non-Orthodox American Jewish day schools had an impact; in these venues an eighth grade or $12^{\text {th }}$ grade trip to Israel are part of virtually every curriculum.

Thus, a paradoxical trend was setting in. While more American Jews had been to Israel, an overall increasing number of them were less intensely affiliated with the organized Jewish community and Jewish identity in general. This had as much to say about the overall change of the American Jewish community as anything else. That is, while the overall numbers of those actively involved with the community was shrinking, the core remained vibrant and committed even as the marginally affiliated continued to see their Jewish identity wane in intensity. This was illustrated in the stark decline of numbers of overall American Jews, which declined from 5.85 million to 5.2 million in the decade according to the Nation Jewish Population Study, the most prominent of such publications. ${ }^{315}$ Clearly, intermarriage, assimilation, and lower fertility rates were taking

\footnotetext{
${ }^{314}$ Jonathan Ament, "Israel Connections and American Jews." (New York: United Jewish Communities, 2005), p. 5.

315 "Highlights of the 1990 National Jewish Population Survey." (New York: Council of Jewish Federations, 1990), p. 5. "National Jewish Population Survey 2000-2001: Strength, Challenge and Diversity in the American Jewish Population." While the studies were criticized by some observers for data collection methods and the representation of some groups (such as Orthodox Jews and intermarried couples), having the same organization produce the works in 1970, 1990, and 2000-2001 (including numerous additional reports on the data) gave general reliability to the trends revealed by the data.
} 
their toll as one would have expected Jewish population numbers to rise at least slightly in a decade due to natural birth.

\section{IV.9 Changes In American Jewish Identity}

The overall concern of distancing from Israel also can be seen when comparing other statistics from the NJPS surveys. Every demographer agrees that the more connected an individual is to synagogues and community institutions, the closer he or she is to Israel and the more informed he or she is about Jewish life in Israel and elsewhere. That's why community planners have continually worried about the rise of people who voluntarily take the label "just Jewish" over the more traditional responses of "Orthodox, Conservative, Reform, and Reconstructionist.” For example, in 1990 about 10.1 percent of American Jewish adults labeled themselves "just Jewish" while another 9.4 percent took the label "other."316 A decade later, the number for "just Jewish" (the "other" label was not offered in that survey) rose to 26 percent - an increase of more than five percent. $^{317}$

Meanwhile, those who were involved with the community were becoming more focused on their individual denominations than the community as a whole. In part, this was the spirituality movement in which Jews (and other Americans) sought to cultivate new forms of identity that were by their nature more personal and less communal. There was no longer a kneejerk response to communal needs for many, but a desire to

\footnotetext{
${ }^{316}$ Sidney Goldstein, "Profile of American Jewry: Insights From The 1990 National Jewish Population Survey.” (New York: Council of Jewish Federations, 1993),p. 170.

${ }^{317}$ Ament, p. 9.
} 
understand the whys of what were seen as traditional Jewish obligations for public actions. One result was that Jewish political activism - at least from non-Orthodox groups such as the Conservative and Reform camps which - was getting more text-based, of course using interpretations that fit the denomination's philosophy. That came as a result of the spirituality push of the day, a hybrid of the "continuity agenda" that focused on building Jewish identity as a means to long-lasting attachment to "Jewish peoplehood," to borrow the phrase popularized by Reconstructionist Judaism's founder Rabbi Mordechai Kaplan (1880-1982).

Examples were abundant. Reform Judaism under the leadership of Rabbi Eric Yoffie, who had succeeded the outspoken Rabbi Alexander M. Schindler in mid-1996, was becoming more text-based and spirituality centered, hoping to not jettison its longstanding allegiance to social action, but to infuse those activities with new meaning. As Yoffie had said in his installation sermon of his fellow Reform Jews:

They are searching for the poetry of faith, because the need for transcendental meaning is as present as an open sore. This is a generation that wants to believe; that is seeking a modicum of decency; that is yearning for the sacred. The modern Jew - so successful and sophisticated, so cynical and skeptical - is yearning, knowingly or not, for God. But the tragedy, of course, is that they have no idea how to proceed... What we do need is to declare a spiritual state of emergency, and to pledge ourselves, Josiah-like, to a Movement-wide effort of renewal and change. ${ }^{318}$

Yoffie even advocated the formal recognition by the World Zionist Congress that secular Zionism - which had built the organization from inception in the 1890s - was no longer viable. That is because, he said, it was time for "a full partnership between Zionism and the synagogue world [because] the synagogue is the only vehicle that exists

${ }^{318}$ Eric. H. Yoffie. "Installation Sermon.” 8 June 1996. 
- absolutely the only vehicle - that can reach the Jewish masses and turn them on to the Zionist enterprise." 319

Simultaneously, the Conservative movement sought to assert itself on the national scene through the public policy and Israel oriented Rabbi Seymour Essrog, president of the Conservative movement's Rabbinical Assembly. In 1998, in acknowledging the spiritual growth desires of American Jews, Essrog said, “There is a growing movement across the community that this is how you express yourself as a Jew. Social action is wonderful, but it has to be grounded in authentic Jewish belief and tradition." 320

Orthodox Judaism, in which attendance at Jewish day school is virtually mandatory, already had spirituality and text-learning at its core for actions and observance. Likewise, broader community events such as the 1998 annual UJA Young Leadership conference in Washington, D.C., a training ground for future community leaders, were taking on a tone of spirituality. In fact, talks on "spiritual epiphanies in the mundane" were as popular as ones with Dennis Ross and Israeli ambassador Eliahu BenElissar." 321

Recognizing this increasing sense of individualism and trying to give it a communal context, American Jewish funders and the organized community sought to cultivate personal ties to Israel. No greater effort came than the one to get what became Taglit-Birthright Israel, a free 10-day trip to the Jewish state for Jewish young adults ages

\footnotetext{
${ }^{319}$ Yoffie. "An Address to the $33^{\text {rd }}$ Zionist Congress." 24 December 1997.

${ }^{320}$ Besser, "Power Trip: An Orthodox group's new office typifies the trend toward religious Jewish political activism." Baltimore Jewish Times. 8 January 1998, pp. 34-35.

${ }^{321}$ Besser, "A Yeasty Mix: This year's UJA young leadership conference mixed Middle East politics with spiritual regeneration." Baltimore Jewish Times. 27 March 1998, pp. 42-43.
} 
18 to 26 , off the ground. A highlight of the operation was the mifgash, in which Israeli soldiers - often the same age as the participants - would tour with their American Jewish counterparts and hopefully form personal bonds that would last beyond the trip.

Signaling the importance of the effort, the Jewish Life Network - founded in 1994 and funded by "mega-donor" Michael Steinhardt - devoted the second issue of its publication Contact - the name itself telling for its emphasis on reaching younger Jews alienated from the high profile, well-established communal structure -- to "Israel and the Future of American Jewry." In it, Rabbi Irving "Yitz" Greenberg and Steinhardt explored the American Jewish connection to the Jewish state. Yet, even with Steinhardt as the top cheerleader for the program, Israel was far from the only focus of his magazine. For example, the next two issues had the respective themes "Is Hebrew School Dead?" and "The Lost Jewish Generation" (the latter geared toward plugging into the spirituality of young Jews). After dealing with topics such as Jewish life on college campuses, social action/volunteerism, and the general state of Jewish education in America, Israel would not again be a topic for the publication until the spring of 2001 when it devoted its issue to "Birthright Israel: The Next Phase.",322

\section{IV.10 Israel At 50: American Jews Take Stock}

Amidst all this, in May 1998 the State of Israel celebrated the $50^{\text {th }}$ year of its founding. Jewish communities throughout the United States and the world held widely publicized festivals, parades and other celebrations. In addition to the overwhelming support for a Jewish state - something not universal in 1948 - American Jews could take

${ }^{322}$ Contact, 1:2, (1998), 1:3 (1998), 3:3 (2001). 
heart in the response of their fellow Americans when it came to supporting Israel. A 1998 poll by The New York Times found that 58 percent of Americans sided with Israel over 13 percent for Palestinians. The rest either had no opinion or favored neither. ${ }^{323}$ This was all reflected in the national attention given to the event from special reports in major daily newspapers such as the The New York Times and the Los Angeles Times to the April 15 two-hour, prime-time TV extravaganza on CBS titled "To Life! America Celebrates Israel's $50^{\text {th }} .{ }^{324}$ Not surprisingly, U.S. Jewish weeklies ran special sections and cover stories, wrapping their coverage of the celebrations throughout the paper that week. ${ }^{325}$ But the State of Israel's successes were not the only thought for many American Jews. True, the bulk of the attention was given to Israel's impressive gains over the years - surviving five full scale wars, an intifadah, constant threats of terrorism, and absorbing millions of refugees while building the region's strongest economy. Yet, the focus also was a chance to ring alarm bells on the declining state of Israel-Diaspora ties. For example, political scientist Dr. Robert O. Freedman wrote that a major problem facing Israel over the next 50 years will be "working out a new relationship" with American Jews. ${ }^{326}$ In part, that's because Netanyahu's handling of the conversion crisis "has been a major blow to ties.” As James. D. Besser, Washington correspondent for several

\footnotetext{
323 “Opinion Poll: Israel and the Palestinians: American Impressions.” New York Times. 26 April 1998.

${ }^{324}$ The retinue of stars who turned out, Jewish and non-Jewish were an acknowledgement of Israel's role in the American mindset.- Kevin Costner, Michael Douglas, Harry Connick, Jr., and Steven Spielberg were among those appearing. There was even a videotaped appearance by President Clinton. J.J. Goldberg, "Love Letters," Baltimore Jewish Times. 24 April 1998, pp. 56-57.

${ }^{325}$ See, for example, Atlanta Jewish Times, Baltimore Jewish Times, Detroit Jewish News and the New York Jewish Week editions of 24 April 1998. James. D. Besser, "Separation Anxiety," Baltimore Jewish Times, 24 April 1998, p. 54.

${ }^{326}$ Dr. Robert O. Freedman, “Israel At 50.” Baltimore Jewish Times, 24 April 1998, p. 12.
} 
prominent American Jewish weeklies, added, “American Jews love Israel... [but] many are finding it harder and harder to like it." ${ }^{327}$ The CCAR Journal - the intellectual magazine of the Reform rabbinical organization - tackled this by devoting its Spring 1998 issue to the new challenges of being a Reform Zionist with articles such as "The New Zionism for the New Zionist Century," "Toward A Post-Nationalist Paradigm of Zionism," and "Hatzi [Half] Zionism.",328

The increasing overall distance from the State of Israel was clear to Arnold M.

Eisen, a prominent academic in modern Jewish thought. On the occasion of Israel's birthday, in an essay published in the 1998 American Jewish Yearbook, he wrote:

Most American Jews are profoundly grateful for Israel's existence, and many understand its importance to their own existence. For them to draw closer to Israel, however, would require a degree of distinctiveness from Gentile America and an intensity of engagement with the burdens of Jewish history and traditions that the majority of American Jews are simply unwilling to undertake. Such Jews will likely not draw closer to Israel any time soon... ${ }^{329}$

Still, Eisen noted that the State of Israel had created an inalterable difference in the weltanschaaung of the American Jewish psyche. As he also wrote:

It seems pointless to me to argue any longer, as Jews have often argued over the past five decades, over whether Israel deserves to be considered the political center of the Jewish people, or whether it has earned the right, culturally or morally, to be considered the spiritual center [because that was now de facto reality]... One

\footnotetext{
${ }^{327}$ James. D. Besser, “Separation Anxiety,” Baltimore Jewish Times, 24 April 1998, p. 54.

${ }^{328}$ Hirsch, Amiel et.al. "A Symposium: Reform Judaism and Zionism.” CCAR Journal Spring 1998. 26.3 (1998): 1-54.

${ }^{329}$ Eisen, Arnold M. "Israel At 50: An American Jewish Perspective.” American Jewish Yearbook 1998. (New York and Philadelphia: The American Jewish Committee and The Jewish Publication Society, 1998), p. 48. In the summer of 2007, Eisen became Chancellor of the Jewish Theological Seminary of America, the flagship academic institution of Conservative Judaism.
} 
shudders to think what American Jewish life would be like in the absence of Israel. ${ }^{330}$

\section{IV.11 Netanyahu Loses Power}

As Israel's May 17, 1999 election date closed in, Clinton found himself fending off the claims of Netanyahu's critics that the U.S. President was interfering in Israel's political process. His favoritism of Labor Party candidate Ehud Barak seemed clear to many observers. ${ }^{331}$ While Clinton rejected the claim, Democratic Party heavyweight strategists and pollsters James Carville, Stanley Greenberg, and Robert Shrum were hired by Barak's campaign to shape the race against Netanyahu. ${ }^{332}$ Again revealing the U.S. bipartisan nature of support for and deep interest in the State of Israel - Democrats for Barak and Republicans for Netanyahu - the incumbent Likud Party leader had some American help as well. That came, as it did in the 1996 campaign, with the help of GOP campaign manager Arthur Finkelstein, whom Netanyahu hired to help direct his reelection effort. ${ }^{333}$

\footnotetext{
${ }^{330}$ Eisen, p. 69, p. 71.

${ }^{331}$ James D. Besser, "Lessons Unlearned.” The Baltimore Jewish Times, 26 May 1999, pp. 36-37. Barry Rubin, however, writes that Clinton's public statements and actions did not overstep the bounds of showing general support for the consistency of U.S. policy in pushing the peace process forward. Barry Rubin, "External Influences on the Israeli Elections," in Israel At The Polls 1996. Eds. Daniel J. Elazar and Shmuel Sandler. (London: Frank Cass, 1998) pp. 1250-158.

${ }^{332}$ Daniel Kurtzman, “Carville And Company Credit Barak, Not Themselves, For Victory," Jewish Telegraphic Agency, 30 November 1999. Center Party candidate Yitzhak Mordecai was also in the prime minister's race, but was basically ignored by the two other campaigns in the final month of the race. Also, for comments by Barak's American pollsters just after the election, see Leslie Susser, "Brief Encounter." The Jerusalem Report, 7 June 1999. p. 11

${ }^{333}$ Larry Derfner, “The Americans Cometh,” Baltimore Jewish Times, 14 May 1999, p. 32. Finkelstein had helped shaped Netanyahu's successful 1996 campaign. In 1996, Finkelstein had come up with Netanyahu's winning slogan "Netanyahu will make a secure peace" - "shalom batuach."
} 
Nonetheless, American Jews seemed to be paying less attention to this Israeli ballot. That was understandable as a sense of Israeli election fatigue was likely setting in. After all, this was the Jewish state's third national election in eight years and one that could give Israel its fifth prime minister in nine years. In additional to the communal focus inward, the lack of attention also likely stemmed from the mutual distrust Netanyahu had cultivated from both American Orthodox and non-Orthodox Jews. The latter were angered by his handling of the conversion crisis while the former were upset with his withdrawing from 80 percent of Hebron and the pending promise of another 13 percent of the West Bank. ${ }^{334}$

That's not to say that there was no interest among American Jews. In fact, Israeli Americans in particular - such as Hollywood millionaire Haim Saban - were actively supporting candidates while paying careful attention to not violate Israel's campaign finance laws. As a result, they set up fundraising efforts for their preferred candidates (in Saban's case it was centrist party candidate Yitzhak Mordecai, who came in a distant third) and gave money to operations that enabled Israelis living in America to return home and vote. ${ }^{335}$

When the election results came in late in the evening in Israel on May 17, Israel had a new prime minister in Labor Party leader Ehud Barak. Rather than get smoothly back on track - at least as Washington and much of American Jewry would understand

\footnotetext{
${ }^{334}$ Adam Nagourney, "The World: For American Jews, Israeli Politics Is A World Away,” New York Times. 16 May 1999. Also, James D. Besser, "Yawning At Zion," Baltimore Jewish Times, 23 April 1998, p. 39.

335 Jonathan Broder, "Heeding The Call.” The Jerusalem Report. 29 March 1999, pp. 34-35. Israeli law allows anyone with an Israeli passport to vote in national elections if they are in the country. In this period there were wide ranging estimates of between 150,000 and 300,000 Israelis living in the United States (the range often having to do with how the children of Israelis born in America were counted).
} 
the term - for the next 18 months the U.S. role in the tumultuous peace process was about to become more intense and sustained than ever. Ultimately, American Jews, Israelis and an outgoing Clinton administration were about to see a comprehensive Arab-Israeli peace seemingly within their grasp only to fall to a spasm of violence that would become the Al-Aksa or second Intifadah. 


\section{Chapter V. The Barak Years}

\section{V.1 From Camp David II To Intifada II}

During the lead up to Israel's May 17, 1999 national election, the Clinton White House all but openly showed its favoritism of Israeli Labor Party leader Ehud Barak over Likud Party incumbent Binyamin Netanyahu. Yet, with the Barak campaign's hiring of people such as Democratic party strategist James Carville, that preference seemed clear. Indeed, U.S. Secretary of State Madeleine Albright expressed her colleague's sentiments when she wrote that Barak's strong victory "was greeted with smiles from the Oval Office to the corridors of Foggy Bottom" (home of her U.S. Department of State). ${ }^{336}$

More to the point, in Barak the U.S. president saw a chance to make the type of progress in the Arab-Israeli talks that seemed impossible during the strains of the Netanyahu years. In fact, during his first visit to Washington as Prime Minister, Barak directly told his American counterpart "that he wanted to complete the peace process and believed that his big election victory gave him a mandate to do so."337 That also fit well with the widespread speculation that Clinton - deep into his second and final term -- was looking for an historic agreement that would both create peace in the troubled region and cement his legacy in a positive light; he certainly did not want the 1998 Monica

\footnotetext{
${ }^{336}$ Madeleine Albright. Madame Secretary: A Memoir. (New York: Hyperion, 2003), p. 602.

${ }^{337}$ Bill Clinton. My Life. (New York: Vintage Books, 2005), p. 867. The comment came during one of Clinton's late nights with Mideast leaders. He and Barak stayed up until 3 a.m. at the Camp David presidential retreat on July 15, 1999. Showing Clinton's penchant for creating personal ties with Israeli leaders, he had invited Barak and his wife, Nava, to join him at the retreat with Hillary Clinton.
} 
Lewinsky scandal, which had led to impeachment proceedings against him, to become his administration's defining moment. ${ }^{338}$

Adding to Clinton's sense of urgency was the death of veteran Mideast leaders who had for decades been both partners (overt and covert) and obstacles in peace making efforts. Each had been part of a cadre of experienced, somewhat predictable leaders who - after surviving various challenges including assassination attempts -- were in solid control of their countries. Indeed, by mid-1999 Israel's Rabin had been dead for three and a half years. Jordan's King Hussein had died in February 1999. Morocco’s King Hassan II would die in July $1999^{339}$ and Syrian President Hafez Assad would die in June 2000. ${ }^{340}$

In Barak, Clinton and many others were eager to see the inheritor of Rabin's legacy of a proven strategic thinker unafraid of making controversial moves that would bring an expected vociferous political opposition. Also, unlike Shimon Peres and very much like Rabin, Barak had a fabled military background and had risen quickly through the political ranks. Barak, as press reports frequently included, was both the most decorated soldier in Israeli history and a former Israel Defense Forces Chief of Staff (1991-1995). As a military man, he was intimately involved with the implementation

\footnotetext{
${ }^{338}$ Martin Indyk. Innocent Abroad: An Intimate Account of American Peace Diplomacy in the Middle East. (New York: Simon \& Schuster, 2009), p. 304. Indyk also notes that Clinton wanted a peace deal done in the summer of 2000 so as to not overshadow Vice President Al Gore's campaign to be his successor in the November elections.

${ }^{339}$ Hassan had secretly helped arrange Egyptian President Anwar Sadat's visit to Jerusalem in 1977. He also had met clandestinely over the years with Yitzhak Rabin and Shimon Peres. He finally met openly with the former in 1993 as Rabin was traveling home after the Oslo signing. In 1986, to the dismay of most Arab rulers, Hassan met openly with Peres. Joseph R. Gregory, "Hassan II of Morocco Dies At 70." New York Times. 24 July 1999.

${ }^{340}$ As Albright summed up the failed Israeli-Syrian negotiations in early 2000 and the sense of time running out, "Meanwhile the sands of the hourglass continued to slip away. President Clinton did not have much time left. Asad [sic] had none. On June 10, 2000, the Syrian president died of a heart attack, having failed to recover an inch of his country's land." Albright, p. 612.
} 
phases of the Oslo Accords' early years. Meanwhile, just as did Rabin, he maintained the Defense Minister's portfolio. Echoing the American's reverence for Barak, even five years out of office Clinton remembered the Israeli as "a brilliant Renaissance man." "341 Reflecting the sense of excitement and hope the Israeli leader brought to peace efforts, during Barak’s July 1999 visit to Washington, D.C., the White House hosted its largest dinner ever. The Israeli prime minister was the guest of honor and much of American Jewish leadership was in attendance. ${ }^{342}$

Still, Clinton and other U.S. leading politicians and diplomats were not going to form the close bond with Barak that they had cultivated with Rabin. Indeed, for all the praise, Barak's personality became increasingly problematic for U.S. negotiators. On the one hand, when pushed, he could be candid and remarkably detailed with them regarding his ultimate desires. On the other hand, as exemplified during the Camp David talks in the summer of 2000, at times he did not trust the Americans enough to share with them his final positions; doing so would have enabled them to work in concert to craft bridging proposals to meet Palestinian demands. As Dennis Ross wrote of his time at the Camp David summit, "Barak, as usual, had his own sense of timing and his own game plan. It

\footnotetext{
${ }^{341}$ Clinton, p. 854. Barak was known not only for daring and heroic military exploits, but graduate work in economic engineering systems at Stanford University, being a concert level pianist, and having a hobby of taking apart and putting back together watches

${ }^{342}$ Lawrence Grossman, “American Jewish Communal Affairs.” American Jewish Yearbook 2000 (New York and Philadelphia: The American Jewish Committee and The Jewish Publication Society, 2000), p. 233. According to then Rabbinical Assembly President Rabbi Seymour Essrog, a ticket to the dinner was a hot item among Jewish leaders. Interview with Rabbi Seymour Essrog. 25 July 2000.
} 
was not ours",343 and "as usual, Barak was either underestimating or misreading the impact of his behavior on others." 344

Still, long-term peace was Barak's stated agenda, a desire that seemed a convergence of four factors: an extremely high level of self-confidence; ${ }^{345}$ his belief that the incremental steps of the Clinton administration would not work ${ }^{346}$ his own awareness of the pending exit of the Clinton administration, whose negotiators had gained trust by both Israelis and much of the Arab world; ${ }^{347}$ and the aging of Palestinian leader Yasser Arafat, whose successor was unclear. ${ }^{348}$

Likewise, Barak and the Americans felt that both Arafat and Assad were the most likely among their people's leaders who could both cement and keep a peace deal. While

${ }^{343}$ Dennis Ross. The Missing Peace: The Inside Story of the Fight for Middle East Peace. (New York: Farrar, Straus and Giroux, 2004), p. 654.

${ }^{344}$ Ross, p. 684.

${ }^{345}$ Aaron David Miller relates an amusing story of how Norwegian diplomat Terje Larson told him that shortly after Barak's election, he was in the Israeli leader's house. Barak, arms waving in karate chop motions, declared, "You Oslo people would chop the tail off like salami. I will chop it off... I will have the end of conflict, totally in one go." Aaron David Miller, The Much Too Promised Land: America's Elusive Search For Arab-Israeli Peace. (New York: Bantam Dell, 2008), p. 279.

${ }^{346}$ Barak had publicly criticized Washington for its obsession with the minutiae of the Wye agreement and said the CIA's role in Gaza of training Palestinian counter-terrorism forces was inappropriate. William Quandt, Peace Process: American Deiplomacy and the Arab-Israeli Conflict Since 1967. $3^{\text {rd }}$ ed. (Washington, D.C., and Berkeley, CA: Brookings Institution Press and University of California Press, 2005), pp. 358-359, citing Aluf Benn, “More Strategy, Less Tactics,” Haaretz. 16 July 1999.

${ }^{347}$ It is a well known axiom in American politics that - unless forced to respond to an emergency situation - a second term president nearing the end of his presidency is unlikely to take daring domestic or foreign policy moves, lest they provide fodder for the opposition and thus hamper the campaign of the president's anointed successor, in this case Vice President Al Gore. Likewise, a new administration could take many months to get its foreign policy team up and running, particularly if a new party came to power. Meanwhile, Barak increasingly sensed that without a peace breakthrough, his slipping Knesset majority could lead to his own political demise.

${ }^{348}$ George Gruen. "The United States, Israel and the Middle East." American Jewish Yearbook 2000. (New York and Philadelphia: The American Jewish Committee and The Jewish Publication Society, 2000) , pp. 189-191, citing an Associated Press interview with Barak on 23 September 1999. Arafat was almost 70 when Barak came to power, periodically rumored to be in ill health, and had no clear successor, which in turn could have led to a Palestinian internecine conflict that surely would have derailed peace talks. 
Arafat was far from a trusted figure, he certainly was preferable to Islamic resistance movements such as Hamas and Islamic Jihad, not to mention radical splinter factions within the PLO such as Dr. George Habash's Popular Front for the Liberation of Palestine (PFLP). Meanwhile, rumors about Assad's failing health continued to swirl; in the event of his death, his young, untested son, Bashir, was expected to become the country’s new president. The older Assad was widely understood to be an extremely difficult negotiator, but one who kept his word; indeed, he had scrupulously honored the post 1973 Yom Kippur/October War disengagement accord with Israel.

\section{V.2 Negotiations Jumpstarted}

As promised by Barak, the 18-month period in which he at the helm was the most sustained and comprehensive Israeli-Arab peacemaking effort yet. Yet they certainly did not end as either he, the U.S. government, or American Jews had initially expected.

The peace talks were jolted forward by what Dennis Ross called the "certain urgent, even manic quality" that Barak brought to peacemaking in his effort to "conclude historic peace agreements whatever the political risk." ${ }^{, 349}$ Indeed, both open and secret channels were reportedly bringing real progress to a process that seemed to have languished - at least in the public eye - in the past three years. In fact, there was such a rush to the proverbial finish line during Barak's brief tenure that drafts of final peace treaties with the Palestinians and Syrians were on various tables. If brought to fruition, they would likely pave the way for accords with first Lebanon and then the Arab League itself, literally bringing an "end of conflict" agreement.

\footnotetext{
${ }^{349}$ Ross, p. 521.
} 
However, these efforts all came to failure, despite breaking historic and deeply ingrained discussion taboos for leading Israelis, Palestinians, Syrians, and the entire Arab/Muslim world. First came the Israeli-Syria talks in Shepherdstown, West Virginia from January 6-10, 2000. While Assad's failing health - likely combined with his political caution -- prevented him from attending personally, he did send his trusted Foreign Minister Farouk al-Shara to meet with Barak. Those talks, however, were inconclusive. Both sides did agree to return to meet in nine days, but on January 13, 2000 the Israeli newspaper Haaretz leaked a draft of a potential Israeli-Syrian treaty, detailing Syrian concessions. That outraged Assad, who canceled subsequent talks. ${ }^{350}$

Clinton, however, pressed his team to keep trying, which ultimately brought a final face-to-face meeting between him and Assad. An exhausted U.S. President, on the way home from Pakistan and Oman, met with the Syrian leader in Geneva on March 26, 2000. By now, given the Syrian distrust of Israel due to the draft of the treaty's leak, Assad's failing health, and Israel's unwillingness to cede to Syria the northeast corner of the Sea of Galilee, there was not going to be a quick peace between the two warring nations. $^{351}$

With the Syrian front seeing no progress, Barak quickly switched to the Palestinian one, nearly demanding that Clinton invite him and Arafat to what would be an historic summit at Camp David - the site of the Menachem Begin-Anwar Sadat meetings that led to the 1979 Israeli-Egyptian peace treaty. From the start, some U.S. negotiators were expressing concern that Barak was moving too far, too fast - not fully preparing

\footnotetext{
${ }^{350}$ Albright, pp. 605-609. Also see Ross, pp. 549-565, Clinton, pp. 883-888, and Indyk pp. 257-268.

${ }^{351}$ Clinton, pp. 903-904. Also see Ross, pp. 583-590.
} 
either Israelis or the Palestinians, whose leaders had become accustomed to Israel's begrudging, slow, grinding discussions that were obsessed with security details. ${ }^{352}$

\section{V.3 Camp David To Intifada}

Barak's desires resulted in the Camp David II peace talks in which Clinton and his top foreign policy team hosted the leading Israeli and Palestinian leaders from July 11-24, 2000 at the presidential retreat adjacent to Thurmont, Md. Clinton bought into Barak's idea to go forward with a summit as a way of putting Arafat into a "hightemperature pressure cooker" in which, in the words of Martin Indyk, Clinton would "put Arafat in the pot and turn up the heat." ${ }^{353}$ Both Clinton and Barak hoped to press Arafat into a deal by making him realize that this was his best last shot. ${ }^{354}$ That was because by now Barak's coalition was falling apart, which was likely to result in either new Israeli elections that would likely be won by the Likud's Ariel Sharon or Binyamin Netanyahu, neither of whom were expected to be as generous as Barak would be regarding land for the Palestinians. In addition, Israeli security forces had been warning since February 2000 that without substantial process in negotiations there could be "an explosion of popular

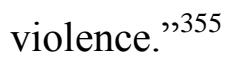

\footnotetext{
${ }^{352}$ Miller cites Dennis Ross's description of Barak during a Washington visit during this period "looking 'like a mad scientist, up all night, there's yellow pages spread around. He's disheveled, hasn't slept, and he's figured out what will work,' and of course he wanted to see the president." Miller, p. 290.

${ }^{353}$ Indyk, p. 290.

${ }^{354}$ Clinton had come to the realization that Barak would not give any more concessions without a Camp David summit. Yet, Indyk criticizes the U.S. President for not putting in more preparation for the summit. Indyk, p. 30.

${ }^{355}$ Ibid, p. 304-305. Netanyahu was still out of the Knesset, but widely discussing his political comeback. Barak, however, called for early elections. The timing meant that only sitting Knesset members could run for reelection, thus precluding Netanyahu running against him.
} 
Meanwhile, the clock on Clinton's time in office was ticking as his term would end in January 2001. In addition, both Barak and Clinton wanted to preempt Arafat from unilaterally declaring a Palestinian state; the second Oslo Accord said that final status negotiations were supposed to be finished within five years, which would be late 2000 . Were Arafat to unilaterally declare a Palestinian state, political pressure was expected to force an Israeli prime minister to annex portions of the West Bank with the majority of Jewish settlers. That, in turn, could set off an international outcry (particularly in the Moslem world), which could turn into a wide scale Israeli-Arab war that could drag in the United States.

For nearly two weeks, the delegations engaged in excruciatingly detailed, physically exhausting and mentally draining talks. There were formal conversations, "back channel talks" (actually "porch conversations"), and much tealeaf reading by and about the principals. Nonetheless, the negotiations failed to produce an agreement. ${ }^{356}$ In some regards, nothing had changed: the most intractable issues remained just that. But in another sense, everything changed at Camp David. That's because - for the first time and with a potential end-of-conflict agreement in sight - the Israelis and Palestinians had agonizingly discussed the most sensitive of issues confronting them. Indeed, the final borders of Jerusalem, control of the Har Habayit/Haram al-Sharif, Jewish settlements, Palestinian refugee repatriation, and more were openly discussed and debated as various creative potential compromises were laid out by American negotiators. For example, at

\footnotetext{
${ }^{356}$ For the most detailed first-person report on Camp David, see Ross, pp. 651-711. Also see Albright, pp. 613-627; Clinton, pp. 911-916; and Quandt, pp. 362-368. For a critical analysis of American response to Barak's insistence on calling a summit as well as general unpreparedness by all sides, see Miller, pp. 295 309. For an alternative view of what happened, one that blames Barak as much as Arafat, see Hussein Agha and Robert Malley, "Camp David: The Tragedy of Errors," The New York Review of Books. 9 August 2001.
} 
one point Israel was willing to give up control of Arab East Jerusalem and the Moslem and Christian Quarters of the Old City. Then, due to Arafat's refusal to accept this, Barak pulled back but still agreed to negotiate a "special regime" (whose details were not yet spelled out) on the Old City. The teams also discussed at length the possibility of Palestinian "custodial responsibility" over the Har Habayit/Haram al-Sharif while the Israelis would maintain "soft sovereignty." For Israel, these were remarkable shifts for a nation whose credo since 1967 of "Jerusalem, Israel's undivided eternal capital" was a broadly accepted political mantra. ${ }^{357}$

For their part, Palestinian negotiators, too, had made major compromises. They had for the first time in nearly seven years of negotiations shown they would compromise on their absolutist demands regarding control of East Jerusalem (but not necessarily on Har Habayit/Haram al-Sharif). Likewise on the repatriation of refugees from the 1948 war, they were talking about conceding that only Israel could decide who would be let back in. ${ }^{358}$

Even with the talks' failure, major change seemed to be taking hold. With pledges by all sides that the conversations would continue after Camp David, a new public attitude seemed to be emerging from some Arab states. While there had always been a vocal peace camp emanating from the Israeli political spectrum, one seemed to be openly

${ }^{357}$ Ross, p. 702, pp. 704-708.

${ }^{358}$ Ibid, p. 703. The idea was originally Ross's, but Palestinian negotiator Nabil Sha'ath accepted it and the sides began discussing how they could work with it.

A Major differences in the Israeli and Palestinian teams is that the Palestinians were clearly more divided due to the presence of hardliners as opposed to Barak's basically left-wing and centrist team. The Israelis after all represented a governing coalition from a nation with a long tradition of democracy, which had led to serious compromise in past negotiations. 
forming in the larger Arab world. As one Saudi official reportedly said, "Jerusalem has a very important religious value, but its political importance is just as great. Maybe both sides could agree on joint administration according to certain arrangements." 359 Coming from within the regime that protected the Muslim world's holiest shrines, the words were no doubt encouraging to Washington and Jerusalem. Some leading Israelis were even publicly welcoming the idea of United Nations control over the Har Habayit/Haram alSharif compound - something not long before unthinkable to nearly every Israeli due to the historic tensions between the world body and the Jewish state over numerous issues. Not the least of these past concerns with the U.N. was its "Zionism is racism" resolution of 1975 (repealed on December 17, 1991 under pressure of President George H.W. Bush as he sought to pave the path for U.N. co-sponsorship of the Madrid Peace Process). ${ }^{360}$

But there also was a bitter aftertaste for some after from the summit. Clinton blamed Arafat for the talks' failure, despite his previous promise to not do so. This was done in large part to help Barak at home; the Israeli leader now ruled over a minority coalition and with the return of the Knesset in the fall, he faced the likelihood of new elections. ${ }^{361}$ Clinton's words at the summit's end were clear to observers:

Prime Minister Barak showed particular courage, vision and an understanding of the historical importance of this moment. Chairman

\footnotetext{
${ }^{359}$ Susan Sachs. "Arabs Strive for New Consensus On an Israeli-Palestinian Treaty," New York Times. 5 August 2000.

${ }^{360}$ Deborah Sontag, "Israel Is Studying Negotiating Ideas Once Unthinkable," New York Times. 23 September 2000. Bush was at the height of his popularity in the aftermath of the Gulf War.

${ }^{361}$ On the eve of leaving for Camp David, Barak's coalition partners Yisrael B'Aliyah, the National Religious Party and Shas pulled out of his government to protest his stands in the peace talks, particularly the possibility of relinquishing Jewish sovereignty over Jerusalem and the Har Habayit/Haram al-Sharif. Barak eventually did call for new elections, in which he was trounced on February 6, 2001 by the Ariel Sharon-led Likud Party, bringing his temporary time-out from politics. Deborah Sontag, "Barak's Coalition Crumbles On Eve Of Summit Talks.” New York Times, 10 July 2000.
} 
Arafat made it clear that he, too, remains committed to the path of peace. $^{362}$

Five days after the negotiators went home, Clinton tried to help Barak further by announcing during an Israel TV interview that he was ready to move the U.S. embassy to Jerusalem as a reward for Israel's securing a peace treaty with the Palestinians. ${ }^{363}$

The two sides did indeed continue their contact after that inconclusive summit, and reported some progress. In fact, on September 26, 2000 negotiating teams sent by the Palestinians and Israelis met at the Ritz-Carlton in Pentagon City, Virginia, in what proved to be productive sessions. ${ }^{364}$ However, within a few days none of that seemed to matter.

\section{$\underline{\text { V.4 The Al-Aksa Intifada }}$}

Negotiations went on, but so did Israeli politics. So on September 28, 2000

opposition leader Ariel Sharon, head of the Likud Party and known for his hard line, nationalist views, took a highly publicized stroll across the Har Habayit/Haram al-Sharif compound. Several hundred Israeli policemen protected him along the way. ${ }^{365}$ (Sharon undertook the visit to boast of his nationalist credentials, part of his efforts to stop

\footnotetext{
362 "In the Words of Camp David Negotiators: 'Unprecedented in Both Scope and Detail." New York Times. 26 July 2000. As Albright put it regarding Clinton's words, "He lauded the Israeli for his vision and courage while crediting Arafat for little more than showing up." Albright, p. 627. Clinton's body language and tone clearly revealed that he was praising Barak and criticizing Arafat.

${ }^{363}$ John Kifner, "Clinton Hints That He Is Ready to Move Embassy to Jerusalem.” New York Times. 29 July 2000. There also was speculation that Clinton was trying to help his wife, Hillary, in her New York Senate campaign by presenting a policy that was favorable to the Jewish community.

${ }^{364}$ Ross, pp. 727-729.

${ }^{365}$ Indyk notes that Palestinian West Bank security chief Jibril Rajoub and Israeli Foreign Minister Shlomo ben-Ami had worked out an understanding that Sharon would not enter the mosques on the platform and there would be no violence. Indyk, p. 353. Clinton, pp. 923-924.
} 
Netanyahu from making a political comeback, which could have ended Sharon's reign as head of the Likud Party.)

The next morning, following services in mosques, Palestinian youth began scattered rioting, which spread in the coming days and developed into what would be called the Al-Aksa or Second Intifada. However, unlike in the first intifada (1987-1993), this time the Palestinians controlled some territory and had a plethora of light arms in the form of machine guns, mortars, jeeps and more - not to mention training from various European security forces and the CIA. Likewise, they had a cadre of suicide bombers that Arafat had until now at least periodically tried to keep in check. ${ }^{366}$

Still, U.S. negotiators tried to temper the violence and get peace talks back on track. On October 4, 2000, the sides met in Paris, which set up the October 17, 2000 Sharm el-Sheikh summit during which Arafat, Barak, Clinton and other world leaders gathered at the Egyptian resort town with much fanfare. ${ }^{367}$ This led to the Sharm elSheikh Fact-Finding Committee (or Mitchell report, named for its leader, former Sen. George Mitchell), which was set up to discover the causes of the Al-Aksa Intifada as well as get the dialogue rolling again. ${ }^{368}$

Finally, with violence continuing and his days in office soon coming to an end, Clinton gave a peace accord one last shot. On December 19, his administration brought key Israeli and Palestinian negotiators to Bolling Air Force Base outside of Washington,

\footnotetext{
${ }^{366}$ John Kifner, "Tale of Two Uprisings: This Time, the Palestinians Have Territory, and Guns." New York Times. 18 November 2000.

${ }^{367}$ Ross, pp. 734-742.

368 "Report of the Sharm el-Sheikh Fact Finding Committee." (Washington: U.S. Department of State, 2001). Also see Indyk, pp. 355-357.
} 
D.C. to continue their work. Four days later, he brought the delegations into the White House and read to them what have become known as the Clinton Parameters. He provided a succinct framework to close the gaps, one that he felt he could bring to fruition in a near non-stop negotiation until the end of his term if both sides agreed to their general direction.

The urgency of the moment was palpable. Not only would Clinton exit the Oval Office on January 20, 2001, but Israel faced national elections on February 6, 2000. It was unlikely that the incoming U.S. administration of Texas Gov. George W. Bush would be as active in the Arab-Israeli peacemaking front as its predecessor, following the logic that it had to first get up to speed (especially in light of the elongated and controversial vote certification of the 2000 campaign) and that it would seek to differentiate itself from the Clinton team. Likewise, were Barak to lose - which seemed increasingly likely without a final status deal with the Palestinians - he would be replaced by Likud leader Ariel Sharon, who simultaneously portrayed himself as a hard line nationalist and a national unifier. ${ }^{369}$

Perhaps the Clinton's most revolutionary idea was the notion that the Palestinians would gain sovereignty "over the Haram" while Israel would have sovereignty over the Western Wall, which formed one of its sides. ${ }^{370}$ The negotiators were told to return in four days with a decision on whether they felt they were prepared to engage in a short-

\footnotetext{
${ }^{369}$ Sharon would in fact set up a national unity government with the Labor Party, as he said he would during the campaign. Barak, however, would be out of office, having resigned from the Knesset after his poor electoral showing. That came despite Sharon's wanting him to stay on as Defense Minister.

${ }^{370}$ Clinton, pp. 936-938. Indyk, pp. 441-445. Also see Jane Perlez, “Clinton Sends Mideast Sides back Home With Deadline," New York Times. 24 December 2000, Albright, pp. 630-633, Indyk, pp. 366-371 and Ross, pp. 748-758.
} 
burst, marathon negotiation, centering on the parameters, to reach a final peace pact. While the Israelis accepted, with the condition that the Palestinians would, Arafat dragged out the talks, ostensibly making a deal on Clinton's watch impossible. ${ }^{371}$ Nonetheless, Clinton remained hyper-involved in trying to persuade Arab leaders to pressure Arafat to sign, which Barak had done - albeit with reservations that were within the presented outline. ${ }^{372}$ Arafat, however, did not consent but tried to string out the negotiations even longer. As Indyk wrote, "Clinton and his advisers had all become so keen to salvage an agreement in the last six months of the administration that we suspended disbelief when the artful dodger [Arafat] promised Clinton the moon." ${ }^{, 373}$

Even with Clinton gone from office, the Israelis and Palestinians - facing Barak's desperately fading chance for an electoral miracle in Israel's February 6, 2001 ballot gave final status talks one more shot. From January 21 to 27 they met at the Egyptian Taba resort without American interlocutors. While the Palestinians did present a West Bank map for the first time, they continued to reject Clinton's proposal - accepted by the Israelis - that the Jewish state would have sovereignty of the Western Wall and underneath the Temple Mount (but not atop it). Violence brought the negotiations to a close when two Israelis were shot while eating in a West Bank restaurant. Barak, reading

\footnotetext{
${ }^{371}$ Indyk, pp. 367-368, and Ross, pp. 751-753.

${ }^{372}$ Clinton, pp. 936-938. Clinton writes that "I was calling other Arab leaders daily to urge them to pressure Arafat to say yes. They were all impressed with Israel's acceptance and told me they believed Arafat should take the deal."

${ }^{373}$ Indyk, p. 376. Ross writes, "Those who argue that we just ran out of time ignore the many opportunities that Arafat refused... Yasir [sic] Arafat had definitively demonstrated that he could not end the conflict," $p$. 757.
} 
the political implications of continuing the talks, called his negotiators home. ${ }^{374}$ For all intents purposes, the once heralded Oslo process that had become a centerpiece of the Clinton administration's foreign policy efforts, had come to an inglorious end.

\section{V.5 Barak And American Jews}

Paralleling his changing stand with the Clinton White House, Ehud Barak's ties with American Jews went from being one of greeting a hero to disenchantment by the end of his time in office. Despite the high hopes of many that Barak would get the peace process back on track, he came into office with real disadvantages regarding his standing among American Jews, whose support he hoped to have to push the U.S. Congress to fund his hoped-for withdrawal of Israeli troops from Lebanon (a campaign promise) and subsequent advances in the peace process.

For starters, he did not bring to his position either a role in the State of Israel's founding years, as had Shamir, Rabin and Peres, or being part of a family with deep connections to modern Zionism's ideological figures. ${ }^{375}$ His immediate four predecessors always seemed to include in their major addresses to foreign Jewish audiences comments on the need to strengthen Jewish identity in the Jewish Diaspora, which in turn would bolster allegiance toward Israel and hopefully aliya. By contrast, when Barak veered from discussing the peace process, he often turned to the less emotional tie of the Diaspora's economic role in helping his country. For example, his November 1999 talk to

${ }^{374}$ Indyk, pp. 371-372.

${ }^{375}$ Netanyahu's father, Ben-Zion, was a prominent scholar of Jewish history and one-time secretary to Zionist Revisionist founder Vladimir "Ze'ev" Jabotinsky, whose ideology framed the basis of Netanyahu's Likud Party. Likewise, Netanyahu's brother, Yoni, was the only Israeli military casualty of the daring 1976 Entebbe raid in Uganda that freed Israeli hostages from the hold of Palestinian terrorists. 
the General Assembly gathering in Atlanta, Ga., at first dealt at length with the peace process. Then he spoke of business opportunities in Israel for Diaspora investors. ${ }^{376}$ Much of American Jewish leadership, however, were distracted with the difficult issues surrounding the structure and purpose of a merging of the Council of Jewish Federations, the United Jewish Appeal, and the United Israel Appeal into the newly named United Jewish Communities. $^{377}$

By the time of his next talk to the G.A., in Chicago in November 2000, the second intifada was in full force and Barak's political career was in serious trouble. As a result, he trumpeted the unity card with American Jewry in this time of crisis. ${ }^{378}$

In addition, as a newcomer to the political and diplomatic political scene, Barak had few long-term personal relationships with American Jewish leaders, something that could be valuable in creating backdoor contacts with various administration figures. Indeed, he had only been in politics since 1995, having become Rabin's Minister of Interior seven months after retiring from a highly successful 35-year military career. By June 1996 he was back in opposition with his Labor Party. ${ }^{379}$ That election, which saw Peres lose to Netanyahu by the thinnest of margins, was Barak's first professional political campaign.

\footnotetext{
${ }^{376}$ Amy Waldman. “Israel's Leader Highly Praises Hillary Clinton,” New York Times. 22 November 1999.

${ }^{377}$ Marilyn Henry. “GA Ends With United Body, Divisive Issues,” Jerusalem Post. 21 November 1999, p. 3. Also see "In The Same Boat,” Jerusalem Post. 19 November 1999, p. 8-A. Editorial.

${ }^{378}$ Ehud Barak, "Remarks by Prime Minister Barak to the General Assembly of the Council of Jewish Federations-Chicago 13 November 2000." Israel Ministry of Foreign Affairs. 13 November 2000.

${ }^{379}$ Barak was not even elected to the Knesset until the 1996 elections, having served as Minister of the Interior and then - after Rabin's assassination - as Minister of Foreign Affairs as a political appointee.
} 
Further, while Rabin's gruffness was often excused with subsequent apologies, Barak's overly confident personality did not lend to such fence mending. In fact, to the displeasure of most American Jewish leaders, Barak wasted little time echoing Rabin's disdain for what he deemed their interference in his affairs. Just as did Rabin, his political mentor, Barak came into office already on record as against AIPAC's hard-line stances when it came to compromising on Palestinian behavior. Not surprisingly, Barak criticized AIPAC's promotion of Netanyahu's policies.

AIPAC had made the situation worse by inviting Prime Minister Netanyahu, but not opposition Labor Party's Barak, to address its late May 1999 policy conference in Washington, D.C., always a high profile and closely watched event amongst the proIsrael community and Washington politicos. AIPAC leaders apparently assumed that with a three way race - immediate past Defense Minister and Center Party leader Yitzhak Mordecai dropped out of the race literally the day before the election - the vote would not produce a clear winner and there would be a runoff between the top two candidates two weeks later. ${ }^{380}$ Thus, Netanyahu would still be prime minister at the time of the AIPAC conference. However, Mordecai pulled out and endorsed Barak, who won convincingly. As a result, AIPAC actually disinvited Netanyahu and invited Barak, but the prime minister-elect turned down the offer. ${ }^{381}$

\footnotetext{
${ }^{380}$ A fourth candidate, right-wing legislator Benny Begin, also dropped out that same day. An Israeli Arab legislator, Azmi Bishari, had ended his unrealistic protest candidacy the previous evening. Deborah Sontag, “Two Candidates Quit In Israel on Day Before Elections,” New York Times. 17 May 1999.

${ }^{381}$ Gruen, 2000. p. 232. This revealed a basic flaw in Israeli leadership attitudes toward American Jews. Israeli politicians naturally wanted American Jewry to back their stands - as long as they were in power. The dilemma for mainstream American Jewish groups is particularly evident at the beginning of an Israeli administration, which often stakes its claim to legitimacy on reversing the attitudes of its predecessor. AIPAC, however, is charged with representing the government of Israel's interests in Washington, and
} 
Also mirroring Rabin's often tense relationship with American Jewry, it was not Barak alone among top Israeli officials who was irritating American leaders. When David Ivry, Barak's new ambassador, came to Washington in February 2000, the former Israeli Air Force head wasted little time in rattling nerves. In delivering his message - "Don't you dare challenge the security credentials of Israel's most decorated soldier" [Barak] he was perceived to be trying to give marching orders to those who were supportive while diminishing the invective of the right. However, to some it was just more criticism from Israeli leaders directed at well-intentioned American Jewish supporters. ${ }^{382}$

Finally, while Israeli President Moshe Katzav, elected by the Knesset on July 31, 2000, was not appointed by Barak, he contributed to the atmosphere of tension. On Wednesday, September 13, in public remarks to 400 Diaspora educators in Israel for the Jewish Agency for Israel-sponsored first World Congress for Directors in Jewish Informal Education, he bluntly offered the classic Zionist ideology line that "only aliya [immigration to Israel] can prevent assimilation." 383 To many, this simply continued the invective of Katzav's predecessor, Ezer Weizman, who had derided Diaspora Jewish leaders during a 1994 conference he had hosted on Diaspora-Israeli ties. As Yossi

changing perspective the day after an Israeli election is understandably difficult. Meanwhile, AIPAC has not made the same mistake of not inviting an Israeli opposition leader ever since its 1999 error with Barak.

${ }^{382}$ James D. Besser, “Fearless: Israel's new ambassador isn't wasting time in pushing his country's agenda - even if it irritates American Jews." Baltimore Jewish Times. 25 February 2000, p. 28. Ivry had defense credentials of his own. He saw combat as an Israeli Air Force in the 1956 and 1967 wars. He also headed the Israeli Air Force from 1977-1982, during which he oversaw the 1981 raid on the Iraqi nuclear reactor in Osirak.

${ }^{383}$ Gil Hoffman, “400 Visiting Diaspora Educators Say Katsav Has A Lot To Learn.” The Jerusalem Post. Internet edition. 14 September 2000. Web. 22 February 2009. 
Alpher, an American immigrant to Israel and expert on Diaspora affairs said of the latest episode, "It's one more contribution to the distancing of Israel and the Diaspora.",384

\section{V.6 Pluralism and Peace}

On the two most important matters on American Jewry's pro-Israel agenda religious pluralism and the peace process - the expected splits between Orthodox and non-Orthodox groups were clear.

When it came to the former, Barak already had been on record during the 1999 race as "against any campaign that divides the Jewish people." ${ }^{385}$ While that expression could be open to interpretation, there was little doubt that Barak - with no personal religious background and no long experience with Diaspora concerns - favored minimal involvement by the government in religious affairs. Despite that, upon his election the U.S.-based Orthodox Union (a traditional supporter of the soon-to-be Barak coalition partner the National Religious Party or Mafdal) warmly greeted Barak’s call for Jewish unity. Officially, it declared that Barak "has proven to be a man of appreciation for and great understanding of the role and importance of Jewish tradition in Israeli society and for the Jewish people as a whole." ${ }^{386}$ However, OU President Mendy Ganchrow would

\footnotetext{
${ }^{384}$ Michael Arnold, “'Don’t Legitimize Diaspora,' Israel's New President Warns.” Forward. Internet edition. 15 September 2000. Web. 22 February 2009. At the same time, Alpher noted that the sentiments expressed by Katsav were diminishing in the general Israeli population due to its increased contact with world Jewish communities through business, vacations, and Israeli relatives living abroad.

${ }^{385}$ Grossman, "Jewish Communal Affairs.” (2000), p. 230.

386 "OU Congratulates Prime Minister-elect Barak on Election Victory." Union of Orthodox Jewish Congregations of America. Press release. 24 May 1999.
} 
recall it differently. "Barak," he wrote, "like many Labor Party leaders before him, never figured out how to reach out to Orthodox Jews, whether in Israel or the diaspora."387

In fact, as Barak's support form the religious sector began falling apart with seeming advances in peace talks that could bring compromises on Jerusalem, the Israeli started pushing his "secular revolution." It called for an Israeli constitution ${ }^{388}$ that would abolish the Orthodox-controlled Ministry of Religious Affairs, allow for civil marriages and burials, create national service for all - particularly the Haredim (ultra-Orthodox) and Arabs, ${ }^{389}$ and make mathematics lessons mandatory in all Israeli schools, something not currently required in yeshivot, ${ }^{390}$ most of which received some form of government funding. That led groups such as the OU to express "profound concern" in the proposal for "sweeping changes" in the status quo. ${ }^{391}$

\footnotetext{
${ }^{387}$ Mendy Granchow, Journey Through The Minefields: From Vietnam to Washington: An Unorthodox Surgeon's Journey. (Silver Spring, Md.: Eshel Books, 2004), p. 255.

388 The Israelis government's quasi-constitutional documents are known as the Basic Laws, which cover areas such as the judiciary, Knesset, government, "human dignity and liberty," state comptroller and so on.

389 The minority Arab communities of the Bedouins and Druze do send most of their 18-year-old boys into the IDF for mandatory service. The exception was the Druze in the Golan Heights, who retained their Syrian citizenship and loyalties due in part to an expected future repatriation to Syria. In addition, a handful of Haredim did participate in the IDF, but not with the consent of their overall community. Meanwhile, modern Orthodox men were increasingly vaunted for their role in combat divisions and officer skills while most modern Orthodox women participated in at least one year of national service, often working in educational roles in development communities.
}

${ }^{390}$ Larry Derfner. "Secular Revolution: Ehud Barak has given up on Israel's religious parties and is pushing hard for an expanded secular base." Baltimore Jewish Times. 25 April 2000, pp. 33, 35. The lack of such secular learning skills was seen as keeping young men in the traditional learning system instead of eventually leaving it and earning a living, which turn them into tax payers instead of continuing to rely on state support and private donations.

391 "OU Urges Preservation of Jewish Character of State of Israel." Union of Orthodox Jewish Congregations of America. Press release. 25 September 2000. Also see Larry Derfner, "Secular Revolt: Ehud Barak pushes a new secular-religious formula." Baltimore Jewish Times. 22 September 2000, p. 38, p. 40. Much to Barak's regret, due to his government's implosion before the July Camp David talks and their failure, his secular revolution did not have time to catch on with non-Orthodox Jews, particularly the Russian immigrants it was aimed at, as he began preparing for a likely new election campaign after the failed attempts to expand his now minority coalition. 
Barak also strived to put the pro-peace process wing of American Jewry back in the spotlight after its three years of being set aside by the Netanyahu administration. So when he came to the United States in November 1999, his itinerary included an address to the Israel Policy Forum, which had been formed in 1993 at the urging of Rabin and Peres to bolster support for their policies amongst American Jews. Barak succinctly shared lines that were to become common in his public addresses: "In 1973, I went to Beirut as an undercover commando," he declared. "Now, in the bright light of day, with no camouflage or disguise, I am a fighter for peace."392

Meanwhile, the American Jewish left and right on Israel continued to fight over who represented the bulk of the nation's Jewish community. On the one hand, the Mideast Forum - comprised of peace process skeptics - was citing a late September 1999 survey that said by an almost three to one margin (60 percent to 22 percent) American Jews felt Israel should not sign a peace treaty with the Palestinians if it required an independent Palestinian state with Jerusalem as its capital. The poll also revealed that by a large 76 percent to 13 percent majority, American Jews did not want Clinton's promise of $\$ 900$ million in aid to the Palestinian Authority to be paid if the P.A. did not remove anti-Semitic and anti-Israel statements from its press and text books. ${ }^{393}$

On the other hand, a July 1999 poll by the Israel Policy Forum - conducted in the optimistic initial days of Barak’s premiership -- showed that American Jews supported the Israeli-Palestinian peace process by a lopsided 88 percent to 11 percent margin. That

\footnotetext{
392 Diana Jean Schemo, “Barak, Addressing American Jews, Stresses Israel’s Yearning for Peace.” New York Times. 21 November 1999.

${ }^{393}$ Daniel Pipes. “A View Of U.S. Jews.” Jerusalem Post. Internet Edition. 28 September 1999. Web. 27 July 2009.
} 
was a general statement that did not follow up on specifics, as did the Mideast Forum survey. Yet, it showed strong general support for the talks. Likewise, the same poll showed American Jews having a favorable view of Barak by a resounding 30 to one margin. ${ }^{394}$ While this second poll was conducted shortly after Barak took office and as a result there was as of yet little to criticize, it also suggested that the Israeli leader had great initial leeway (at least with American Jews) in bringing up controversial topics such as the potential division of Jerusalem. ${ }^{395}$

Despite his eventually promoting a secular revolution, Barak at first moved to pick up the Jewish unity mantle that many felt had been fumbled during Netanyahu's years. He appointed Rabbi Michael Melchior as the country's first Minister of Israeli Society and World Jewish Community, giving him specific responsibilities to keep Diaspora Jewry in the loop when it came to progress on the still simmering issues of conversion - never quite out of Israel's courts - and religious pluralism.

So it was no surprise that Rabbi Melchoir, an Orthodox Jew with political roots in Israel's religious peace movement, found himself in front of American Jewry at the 1999 G.A. in Atlanta. To the satisfaction of the Diaspora leaders, he criticized Israeli legislative attempts to define "Who is a Jew?" Yet, he also noted that he personally advocated Orthodoxy, but did not seek to invalidate other Jewish beliefs. He also backed

\footnotetext{
${ }^{394}$ Matthew Dorf. "Poll: We Like Barak,” Jewish Telegraphic Agency. 15 July 1999. Web. 15 April 2009.

${ }^{395}$ While the two polls asked different questions, they are indicative of how American Jewish groups can use those questions to guide responses that will likely reflect their own views.
} 
the conversion courts set up by Netanyahu's Ne'eman Commission, efforts whose early incarnations were supported by the Israeli Reform and Conservative movements. ${ }^{396}$

Polls and talk of unity aside, there was work to be done. One of American Jewry's first tasks for Barak was to help secure from the U.S. Congress the $\$ 1.8$ billion promised by Clinton to help fund the withdrawals required by the Wye River Accord; the money had been stalled in non-related budget fights between Republicans and Democrats. While there were splits in emphasis - liberal Jewish groups wanting more overall support for U.S. foreign policy and conservative ones seeking more restrictions on funding for the Palestinians - American Jewry in the end coalesced around the aid package and prevailed. $^{397}$

Yet, when it came time to press for a $\$ 450$ million request to help fund the May 2000 Israeli withdrawal from Lebanon, which the Clinton administration supported, the Congress was not in as giving a mood, in part because of the escalating violence in the Middle East and the desire to not put a new, large aid request into a budget that would have to be picked up by the incoming Bush administration. ${ }^{398}$

\section{V.7 Confronting An Israel At Peace}

\footnotetext{
${ }^{396}$ David Weinberg, "Melchior's Promising Moderation," Jerusalem Post, 14 November 1999, p. 6. Also see David Zev Harris, "Melchior to Establish Unity Council Soon,” Jerusalem Post, 6 August 1999, p. 2-A; Carl Schrag, "Barak to Address G.A. in Chicago Tonight," Jerusalem Post. 13 November 2000, p. 4; Marilyn Henry, "Melchior's Affirmative Views Charm Conference," Jerusalem Post. 19 November 1999, p. 6-A; and Neil Rubin, “Unity’s New Warrior.” Baltimore Jewish Times, 7 January 2000, p. 33. In addition, Melchior went out of his way to make himself available to American Jewish journalists, having his aide, Moni Mordecai, set up a press conference and one-on-one meetings at the G.A. and other venues between the minister and journalists.

397 Besser, "Behind the Wye Victory: Jewish groups played an important role - even in opposition to one another.” Baltimore Jewish Times. 12 November 1999, pp. 34-35.

${ }^{398}$ Besser, “Aid Bill Dies.” Baltimore Jewish Times. 22 December 2000, pp. 36-37.
} 
With peace negotiations back on track when Barak came into power, and rumblings of substantial progress emanating from them, American Jewry began grappling anew with a question that first surfaced in late 1993 in the wake of the first Oslo signing: How are we going to relate to an Israel that is no longer embattled? Rabbi Irwin Kula, head of the American Jewish pluralistic think tank CLAL: Jewish Center for Leadership and Learning, summarized the enduring sense of embattlement amongst American Jewry's veteran leadership and the difficulty it posed in exciting younger Jews, a generation raised with a declining sense of overt anti-Semitism and an Israel on the road to peace:

We're victims, we were vulnerable. Therefore, we have to support Israel, fight anti-Semitism and so on. For people who control American Jewish life, that tells them who they are and it's what gets their juices going, no matter what they say. ... What people are beginning to recognize is that this paradigm is not providing sufficient meaning for the younger generation. ${ }^{399}$

Indeed, there were substantial efforts in this period to redirect American Jewish attachment toward Israel from one of defending an existentially threatened spiritual homeland to reconnecting to its population through people-to-people ties, which would hopefully heighten a sense of personal attachment to the State of Israel. A prime example was the Partnership 2000 project of the United Jewish Communities, which created joint committees between Israeli and U.S. communities stocked with upper middle class activists in both venues who were interested in each other's needs beyond political lobbying. Unlike the previous effort on which it was built - Project Renewal - this was not designed to have a U.S. community provide funding for an underprivileged Israeli

\footnotetext{
${ }^{399}$ Rubin, “Peace: Are We Ready?” Baltimore Jewish Times. 24 December 1999, pp. 35-36.
} 
community, but to create joint educational and social opportunities for volunteer leaders in both venues. As a result, delegations of professionals such as Jewish educators and social workers, as well teens began flowing between the two communities. ${ }^{400}$

Likewise, an abundance of smaller attempts to link American and Israeli Jews were being run by various groups outside of the once all-dominating Federation system. They ranged from the primarily Orthodox-funded YESHA fund, which raised money for West Bank/Gaza settlements, to a kibbutz project that enabled American Jews to "adopt," name, and visit a cow. By 1997 alone, such diverse operations - literally hundreds -were estimated to be sending more money to Israel annually than the traditional UJA/Federation framework. ${ }^{401}$

Meanwhile, Taglit-Birthright Israel, the free 10-day trip to Israel for young Jewish adults ages 18-26, developed in 1999 from the Bronfman Foundation's Israel Experience trips. In the spring of 2000 alone, more than 6,000 American participants - chosen from 15,000 applicants -- enjoyed the program. Its $\$ 200$ million initial costs were split between

\footnotetext{
${ }^{400}$ Julia Goldman, "G.A. Helps Bridge The Division Between Israeli and Diaspora Jews," Jewish Telegraphic Agency. 18 November 1998. Also see Debbie Rowe, "Jewish Agency Takes Steps Aimed at Winning Federations' Confidence," Jewish Telegraphic Agency." 2 July 1997; and Rubin, "Coming Full Circle: Through Partnership 2000, can Baltimore's Jewish community re-energize its personal ties to Israel?" Baltimore Jewish Times, 10 March 2000, pp. 42-46.
}

The program actually began in 1994, but did not catch on for several years as various communities continued relationships with their Project Renewal partners as well, which had matched them up with disadvantaged Israeli communities in more of a paternalistic relationship. From 1994 to 2000, North American Jewish federations put about \$75 million into Partnership 2000, marking it as a major undertaking. For a comprehensive history and articles on the project's first 13 years, see "Partnership 2000 Supplement," Haaretz. 9 October 2000. For more on Partnership 2000 historically and today in numerous U.S. Jewish communities, see <http://www.jewishagency.org/JewishAgency/English/Israel/Partnerships>.

${ }^{401}$ Steven T. Rosenthal, Irreconcilable Differences: The Waning Of the American Jewish Love Affair With Israel. (University Press of New England for Brandeis University Press: Hanover, N.H. 2001), pp. 173174. For more, see Jack Wertheimer, "Current Trends in American Jewish Philanthropy," in American Jewish Year Book 1997. (New York: American Jewish Committee and the Jewish Publication Society, 1997), pp. 35-40. 
American Jewish "mega-philanthropists," Jewish federations, and the Government of Israel. $^{402}$

Many of these new efforts were financed by the growing financial and philanthropic power of the American Jewish community throughout the 1990s, a time that saw many new family foundations and private initiatives set up. By 1999, more than $\$ 2$ billion in Jewish family foundation funds were sitting in Federation-administered restricted and unrestricted funds. (Billions more were privately controlled by the same families.) Still, concern was deepening that many younger members of these wealthy families would not in the coming years guide their money toward Jewish community causes. Indeed, Dr. Gary Tobin - a prominent researcher in this area - warned that the growing drop in Jewish affiliation levels of the grandchildren of major donors made cultivating future such givers "one of the critical issues for Jewish life over the next 20 years." 403

Helping coordinate these efforts - and growing rapidly through the 1990s - was the Jewish Funders Network, which had been founded in 1990 by a group of prominent philanthropists. They hired a professional staff and opened membership to individuals or foundations that gave at least $\$ 25,000$ a year "through the lens of Jewish values" to

\footnotetext{
${ }^{402}$ Nina Gilbert, "Barak, Shohat OK $\$ 70$ Million for Birthright Project." Jerusalem Post. 13 October 1999, p. 5. Also see: Gil Troy, "Birthright Israel - Why I Was Wrong." Moment, (25:4), August 2000: 54; and Joel Greenberg, "Trips to Renew Jewish Ties Set Off Debate Over Costs," New York Times. 8 January 2000. The program was so popular in its first few years that participants were chosen by lottery. In the following years, the program expanded substantially. By 2007, more than 100,000 North American young adults had been to Israel via Birthright Israel. For more on the effectiveness of the program, see Shaul Kelner, et al., "Making Meaning: Participants' Experience of Birthright Israel." (Waltham, Mass.: Cohen Center for Modern Jewish Studies, 2000).

${ }^{403}$ Barbara Pash, "Foundations of Giving: Jewish philanthropic organizations are changing the face of Baltimore - and the world." Baltimore Jewish Times. 19 November 1999, pp. 50-56.
} 
philanthropic causes. It originally intended to focus on "supporting progressive secular and Jewish causes, such as Arab-Jewish dialogue, Jewish women's history projects, innovative Jewish and interdenominational education, environmental conservation in Israel.” By 1999, it had 600 members. ${ }^{404}$

\section{V.8 Population Surveys And Jewish Interests}

As all that happened, the profile of American Jewry continued to change. Indeed, the preceding decade had seen a once generally united community focused on three core issues - Holocaust memorialization, freedom for Soviet Jewry, and advocacy on behalf of any democratically elected government in Israel - was now at least as focused internally as it was on the increasingly complicated situation in Israel. Likewise, American Jews who were interested in the pro-Israel agenda now found themselves confronted with an unprecedented multiplicity of organizations. In addition to AIPAC, and the Israel stands of various national defense organizations, there was the Israel Policy Forum, Americans for Peace Now, the Zionist Organization of America (now much more of a right-wing organization than a right-of-center one), the Mideast Forum, and more.

Still, the diverse agendas of such groups competed in the minds of American Jewish leaders and on the pages of Jewish newspapers with other major stories and developments. One of the largest - just as it had been about a decade earlier-was the release of the latest American Jewish Population Survey. This one, the 2000-2001 NJPS, did not occur until the second half of 2003. Its numbers, however, were collected in 2000

\footnotetext{
${ }^{404}$ Kenneth Schultz, "Collaboration Is Name of Game in World of Jewish Philanthropy." Jewish Telegraphic Agency, 29 April 1999. Also see Chanan Tigay, "A New Trend in Jewish Giving?" Jewish Telegraphic Agency, 30 November 1999.
} 
and offer a stark contrast in some areas to the 1990 NJPS. ${ }^{405}$ The impact an NJPS could have on American Jewish priorities had already been demonstrated by that earlier document. Its report on the increasing rate of intermarriage and the waning of Jewish identity had triggered the continuity agenda. Once again, in 2000 statistics regarding intermarriage were a primary concern. While new marriages between Jews and non-Jews were was occurring at an alarming rate, the upward trajectory at least seemed to be leveling off, as they were 47 percent in $2001 .^{406}$

Meanwhile, reflecting a continuing paradoxical trend, those involved with Jewish life - the community's core -- were deemed to be growing in their religious/spiritual attachment to the Jewish people while those on the more quickly growing periphery moved away from communal attachment. As one indication, a record 29 percent of Jewish children were enrolled in Jewish day schools. That was due to both a natural increase in the Orthodox community and the rise in the 1990s of Reform, Conservative and community day schools. Yet, enrollment continued to drop in supplementary afternoon Hebrew and Sunday schools, which overall served a much larger population. At the same time, the later study showed that overall there had been a decline of American Jews from 5.8 million to 5.2 million. Thus, while the percentage of American Jews going to Israel had increased, so had assimilation. A higher percentage of Jews were going to Israel, but they were coming from an overall smaller pool. Helping pump the

\footnotetext{
${ }^{405}$ The document's release had been delayed over questions such as the counting of Orthodox Jews and various statistical debates amongst demographers. Also see Joe Berkofsky, "Population Study Poses Challenges.” Jewish Telegraphic Agency, 8 October 2003. Web. 15 April 2009.

${ }^{406}$ Laurie Goodstein, “Survey Find Slight Rise In Jews Intermarrying.” New York Times. 11 September 2003. In fact, the new report said that the 52 percent intermarriage rate of the 1990 document had been inflated as it should have been 43 percent.
} 
numbers of visitors to Israel to around the 41 percent mark from the 26 percent mark in 1990 was the fact that throughout the 1990s more money had become available for Israel trips, including the already discussed Bronfman Foundation's Israel Experience and then Taglit-Birthright Israel. ${ }^{407}$

The outbreak of violence in Israel created a sense of crisis, which brought a timehonored response by American Jewish identity - an increase in the sense of their attachment to the Jewish State. In fact, in 1997 when asked if they felt "very close" to Israel, 23 percent of American Jews agreed. ${ }^{408}$ By 2003, two years into the Second Intifada, 31 percent agreed. ${ }^{409}$ Parallel to that, more U.S. Jews "agreed" that they should not criticize the policies of the elected government of Israel when it came to peace talks, showing a rise from 55 percent to 63 percent from 1997 to $2003 .{ }^{410}$

Yet, studies continued to show an overall American Jewish distancing from Israel, particularly among younger Jews. Thus, when Israel again needed American Jews to fight its P.R. and political battles in the United States, a younger generation of Jews was not

${ }^{407}$ For the 41 percent mark, see Jonathan Ament, "Israel Connections and American Jews." (New York: United Jewish Communities, 2005), p. 6. Also see "American Jewish Attachment to Israel: An Assessment of the "Distancing Hypothesis." (Waltham, Mass.: Cohen Center for Modern Jewish Studies, 2008), p. 25. For Cohens' most recent slides, see <http://www.jewishdatabank.org/Reports/AJS2008_DistanceFromIsraelHypothesis_CohenVeinstein.pdf〉.

For the 26 pecent mark, see Sidney Goldstein, "Profile of American Jewry: Insights From The 1990 National Jewish Population Survey," in American Jewish Year Book 1992 (New York: American Jewish Committee, 1993), pp. 172.

${ }^{408}$ While the question posed was slightly different, numbers from a poll conducted in 1999 by Steven M. Cohen and Arnold M. Eisen were similar. When asked 'How emotionally attached are you to Israel?' 27 percent said they were either "extremely attached" (9 percent) or "very attached" (18 percent). Cohen, Steven M. and Arnold M Eisen. The Jewish Within: Self, Family, and Community in America. (Bloomington, In.: Indiana University Press, 2000), p. 218.

4092003 Annual Survey of American Jewish Opinion. (New York: American Jewish Committee, 2004), pp. $11-12$.

${ }^{410}$ Ibid. 
interested in the ways that previous ones were. Pro-Israel activism on campuses in particular brought a generation of younger American Jews without much background on Israel in direct confrontation with anti-Israel student groups, many energized by the presence of first-generation American Muslims and Arabs. ${ }^{411}$

More disturbing was the 1999 poll by Steven M. Cohen and Arnold M. Eisen for their book The Jew Within: Self, Family, and Community in America which- supporting an inward turn of American Jews - found a substantial gap between how American Jews felt about each other and about Israelis. When asked how close they felt to "other Jews," 92 percent said either "to a great extent" (37 percent) or "55 percent" (to some extent). When it came to Israelis, however, not only did the overall number drop to 49 percent, but 43 percent said they were "not at all" close. Only 6 percent said they were "not at all close" to "other Jews," by which one can extrapolate was interpreted as American Jews with whom they regularly interacted. ${ }^{412}$

Meanwhile, another survey was creating headlines and concern was The American Jewish Identity Survey: 2001 by Egon Mayer, Barry Kosmin, and Ariela Keysar. It had found that the number of born Jews identifying with another religion had doubled in the past decade from 625,000 to 1.4 million. ${ }^{413}$

\footnotetext{
${ }^{411}$ Beata Shneyer, "Anti-Semitism and Pro-Israeli Campus Activism: A Case Study: University of California, Berkeley." Jerusalem Center For Public Affairs Institute for Global Jewish Affairs. 5 June 2008. Web. 5 August 2009. Also see Jacob Berkman, "Student Spirit: Local college campuses grapple with the Middle East crisis." Baltimore Jewish Times. 20 October 2000, pp. 34-35.

${ }^{412}$ Cohen and Eisen, p. 219.

${ }^{413}$ Lawrence Grossman, “American Jewish Communal Affairs.” American Jewish Yearbook 2002 (New York and Philadelphia: The American Jewish Committee and The Jewish Publication Society, 2002), p. 228.
} 
Also, American Jewish attention was distracted in the last half of 2000 - along with that of the rest of the country -- with the seemingly never-ending presidential campaign, whose vote counting lasted five long, detail-laden weeks. For Jews, always highly attuned to and disproportionately participating in the political process, their focus was even more intense with the selection of Sen. Joseph I. Lieberman (D-Conn.) as the Democratic Vice Presidential candidate. Lieberman was a paradox. An observant modern Orthodox Jew, he was a Democrat and close to President Clinton. ${ }^{414}$ Win or lose, Lieberman's candidacy set him up to be next in line for leadership of the Democratic Party and thus a presidential run. ${ }^{415}$

Lieberman's candidacy electrified American Jews. For many it marked their final acceptance in a once-hostile America. Now not only was there no barrier to Jews at the highest levels of the United States, but they need not compromise their Jewishness by either changing their names or discarding religious practices. ${ }^{416}$ By the time the fall Jewish holidays rolled around, many rabbis of various denominations were delivering

\footnotetext{
${ }^{414}$ The two were leaders of the Democratic Leadership Forum, which helped bring the party back to the center in the early 1990s, thus helping present Clinton as a centrist candidate. Likewise, Lieberman was seen as a man of great integrity for his having been the first Democratic senator to publicly criticize Clinton on September 3, 1998 over the president's affair with Monica S. Lewinsky.

${ }^{415}$ Lieberman did in fact run in 2004, but faired poorly in the primaries and soon bowed out.

${ }^{416}$ Lieberman walked to rallies on Shabbat, kept kosher while campaigning, and regularly attending Shabbat services. David M. Shribman. "The Lieberman Candidacy," in Jews In American Politics, Eds. L. Sandy Maisel and Ira N. Forman. (Lanham, Md. - Rown \& Littlefield Publishers, Inc., 2001), p. xxv. Also see Robert D. McFadden, "The Man In The News: A Man of Steady Habits - Joseph Isador Lieberman." New York Times, 8 August 2000. Also see Richard Foltin, "National Affairs." American Jewish Yearbook 2002. (New York and Philadelphia: The American Jewish Committee and The Jewish Publication Society, 2001) 148-150. For the perspective of modern Orthodox Jews, see Mendy Ganchrow, Journey Through The Minefields: From Vietnam to Washington, an Orthodox Surgeon's Odyssey. (Silver Spring, Md.: Eshel Books, 2004), pp. 284-290.
} 
sermons on all the positive things Lieberman's candidacy said about the presence and acceptance of Jews in America. ${ }^{417}$

The candidate, in fact, spoke so much about his religion - perceived as an attempt to undermine the Republican's “family values" appeal toward religious Christians - that he earned, as noted above, the rebuke of the ADL national chair Howard P. Berkowitz and Abraham Foxman. ${ }^{418}$ Talk of religion was far from a Democratic Party phenomenon in the election. Republican nominee Gov. George Bush of Texas only heightened traditional Jewish concerns over his party by declaring June 19, 2000 to be Jesus Day in his state, in the process urging all Texans to "follow Christ's example by performing good works in their communities and neighborhoods."419

In part, this helped keep American Jews strongly within the Democratic fold. In fact, an overwhelming 79 percent of them opted for the Gore-Lieberman ticket over the GOP's Bush-Cheney team. ${ }^{420}$

\section{V.9 Spirituality and Religious Shifts}

${ }^{417}$ Gustav Niebuhr, "Religion Journal: Ascent of Lieberman Inspires Sermon Ideas," New York Times. 30 September 2000.

418 “ADL To Senator Lieberman: Keep Emphasis On Religion Out Of Campaign.” Press Release. AntiDefamation League. 28 August 2000. The ADL would offer similar warnings in the 2004 campaign to all candidates.

${ }^{419}$ Laurie Goodstein, “The Religion Issue: Bush's Jesus Day Is Called Insensitive and a Violation of the First Amendment." New York Times, 6 August 2000. Also see Foltin, "National Affairs," in American Jewish Yearbook 2002. (New York and Philadelphia: The American Jewish Committee and The Jewish Publication Society, 2001), p. 147.

${ }^{420}$ The Clinton-Gore ticket had gained 80 percent and 78 percent of the vote in the previous two elections. Ira Forman, Jews In American Politics, eds. L. Sandy Maisel and Ira N. Forman. (Lanham, Md.: Rowman \& Littlefield Publishers, Inc., 2001), p. 153. 
While the overall voting patterns of American Jews showed little change during the 1990s, there was substantial movement in the religious practice of many American Jews. The movement toward spirituality - which did not fit neatly into standard religious classification - had increasingly become part of the religious scene for many (as it had for Americans in general). A small but focused minority of Jews seemed to find comfort in more liberal and unaffiliated congregations or chavurot (small, informal prayer groups that build an intimate religious community). Some larger congregations broke members into chavurot, groupings of 10 or so families who met periodically in one another's homes. ${ }^{421}$ In fact, the National Havurah Committee held week-long summer institutes that attracted 300 people.

Meanwhile, authors such as Rodger Kamenetz were writing about how Jewish spirituality meshed with Buddhism, giving name to the so-called Bhu-Jews. ${ }^{422}$ Michael Lerner, a Jewish Renewal rabbi and vocal dove on Israel, had his Tikkun Community, which created conversations around the writings of the Tikkun journal that he edited. Lerner, who had briefly captured Hillary Clinton's attention in the early 1990s with his exploration of the "politics of meaning," seemed to always be working on a book, such as his 2002 title Spirit Matters. ${ }^{423}$ Meanwhile, Rabbis Zalman Schacter Shalomi - a.k.a. "Reb Zalman", the elder statesman of the Jewish Renewal movement - and social activist

\footnotetext{
${ }^{421}$ Some large synagogues, such as the 1,200 membership unit The Temple in Atlanta (Reform), and the 1,500 unit Chizuk Amuno Congregation in Baltimore (Conservative), formed chavurot within the synagogue in which members would meet monthly for Shabbat dinners and other Jewish social activities.

${ }^{422}$ Rodger Kamenetz, Stalking Elijah: Adventures With Today's Mystical Jewish Masters. (HarperOne: New York, 1997).

${ }^{423}$ Michael Lerner, Spirit Matters. (Charlottesville, Va.: Hampton Roads Publishing, 2002).
} 
Arthur Waskow ${ }^{424}$ were leading their followers in what had become a zeitgeist of social consciousness driven by religious spirituality. They wove concerns for environmentalism, nuclear proliferation, poverty, and related themes into writings on how Judaism could speak to global concerns.

There also was an increase in the popularity of Jewish spirituality from a women's perspective and academic Jewish women's studies in general. This was seen in the popularity of Anita Diament's books such as The Red Tent and The New Jewish Wedding. ${ }^{425}$ Numerous synagogues and Jewish women's groups began offering Rosh Chodesh meetings (to mark the beginning of the Hebrew month). Brit Bat ceremonies (similar to the brit milah for boys) marked the welcoming of girls into the Jewish community. There even were special prayers being rewritten - and sometimes rediscovered - that marked milestones in a women life. ${ }^{426}$

This was all part of what Lawrence Grossman has referred to as "privatizing Jewish identity," or "the emphasis on individual self-fulfillment that pervaded American society and that had affected American Jewish life through the 1990s."427 Steven M. Cohen and Arnold M. Eisen noted this in their book The Jewish Within: Self, Family, and

\footnotetext{
${ }^{424}$ Among Schacter-Shalomi's works were Spiritual Intimacy: A Study of Counseling in Hasidism (Lanham, Md.: Jason Aronson, 1996). Waskow's more popular books were Seasons of Our Joy (Boston: Beacon Press, 1991) and God Wrestling Round 2: Ancient Wisdom, Future Paths. (Woodstock, Vt.: Jewish Lights Publishing, 1998).

425 Anita Diamant, The Red Tent. (New York: Picador USA, 1997) and The New Jewish Wedding. (New York: Scribner, 2001). The second title was originally published in 1986, but re-released in a revised edition in early 2001.

${ }^{426}$ One example is Rabbi Nina Beth Cardin's book The Tapestry of Jewish Time: A Spiritual Guide to Holidays and Life-Cycle Events. (New York: Behrman House Publishing, 2000).

${ }^{427}$ Lawrence Grossman “American Jewish Communal Affairs.” American Jewish Yearbook 2002 (New York and Philadelphia: The American Jewish Committee and The Jewish Publication Society, 2002), p. 224.
} 
Community in America, devoting a chapter to "The Sovereign Self." 428 The continuity agenda was thus taking on new directions as numerous people increasingly focused on Jewish identity as it intersected with other concerns - feminism, environmentalism, and the like.

Recognizing both the challenges and the opportunities of this phenomenon, various initiatives were set up to personalize and invigorate the sense of spiritual connectedness and relevance of synagogue communities. One of the more well-known ones was Synagogue 2000, which was founded in 1995 by Rabbis Lawrence Hoffman and Ron Wolfson. ${ }^{429}$ They saw that the increasing push for spirituality and tradition was pervading the entire Jewish religious spectrum. The most striking example came in Reform Judaism. Since taking over the Union of American Hebrew Congregations from Rabbi Alexander Schindler in 1996, Rabbi Eric Yoffie emphasized the shift toward traditional Judaism, albeit through a modern lens. In his June 8, 1996 installation sermon, he noted:

We know that there are many kinds of authentic Jews less traditional and more traditional, activist and contemplative, believing and unbelieving. But this too we know: that whatever kind of Jews we are, we must all be competent Jews, and we must do the work that competence requires... At this critical juncture in Jewish history, it is study of Torah, and prayer, and encouraging the mitzvot of home and family life that come before anything else. Not instead of other things, but before them. ${ }^{430}$

\footnotetext{
${ }^{428}$ Steven M. Cohen and Arnold M Eisen. The Jewish Within: Self, Family, and Community in America. (Bloomington, In.: Indiana University Press, 2000).

${ }^{429}$ The operation has since been renamed Synagogue 3000. More information is at www.synagogue3000.org. A similar operation is STAR ("Synagogues: Transformation and Renewal"), which is at www.starsynagogue.org.

${ }^{430}$ Eric Yoffie, “Installation Sermon,” 8 June 1996. New York. Web. 7 July 2009.
} 
From that moment on he in particular pushed on Reform Jews the need for Hebrew literacy - he was known for reading Israeli papers on a train to his New York office every day - as well as worship and tradition, albeit not in the traditional binding manner of halachah (Jewish law). Following Yoffie's lead, on May 26, 1999, the Reform movement's rabbinical association, the Central Conference of American Rabbis, adapted a new Statement of Principals at their convention in Pittsburgh. Some 114 years earlier that city was the scene of another famous CCAR Statement of Principals, but one that emphasized Judaism's universalism and openness to overturning Jewish tradition for modern, rationalist perspectives and approaches to religious life. Reflecting the new turn toward tradition, the three main sections of the new Pittsburgh Platform were titled "God," "Torah," and "Israel," three words traditionally used to encapsulate the foundation of Orthodox Jewish belief. As but one example, the "Torah" section declared:

"We are called by Torah to lifelong study in the home, in the synagogue and in every place where Jews gather to learn and teach. Through Torah study we are called to mitzvot, the means by which we make our lives holy."431

Meanwhile, the Conservative movement was not without its own shifts during this period. On the one hand, it was acknowledging Reform's rise in popularity amongst affiliated American Jews by seeking to tighten its standards, thereby differentiating itself from Reform in the face of talks by some observers of the inevitability of the merger of the movements. So in 2000, the United

\footnotetext{
431 "A Statement of Principals For Reform Judaism.” Pittsburgh. 26 May 1999. Web. 7 August 2009. Also see Nadine Brozan and Gustav Niebuhr, "Reform Jews Mirror Return to Ritual." New York Times, 1 June 1999. Also see Marc Lee Raphael, "The Emergence and Development of Tradition in Reform Jewish Worship." Jewish History. 15.2 (2001) 119-130. "Mitzvot" literally refers to obligatory behaviors commanded by the Torah, but are often referred to colloquially as voluntary "good deeds."
} 
Synagogue expelled Congregation Ner Tamid of Bloomfield, N.J., which also maintained a previous affiliation with the Reform movement. Likewise, the movement's Ramah camps included on application for staff that they had to be Jewish according to the movement's halachic standards, meaning that either their mother had to be Jewish or they had been converted to Judaism by a Conservative or Orthodox rabbi. ${ }^{432}$

Orthodoxy, too, was undergoing changes. The modern Orthodox movement (sometimes called centrist Orthodoxy), was the organizational face of Orthodoxy for other Jews. Unlike Haredi groups, it participated in forums such as the Conference of Presidents and the Jewish Council for Public Affairs. Its members were increasingly being known for taking leadership roles in local Federations. Modern Orthodoxy, however, had been undergoing a much discussed shift to the right. An example came when a New York rabbi announced an end to social dancing at synagogue events as well as women reading Torah on the synagogue's premises - despite their never having done so in the sanctuary. ${ }^{433}$

One response to such moves was the rise of the Orthodox Feminist

Alliance, which saw 1,000 people turn out for its first conference in February 1997. Some of its early goals including collecting information on new rituals such as naming ceremonies for daughters, new prayers to be said after childbirth, and advocacy on behalf of agunot, Orthodox women who cannot remarry due to their

\footnotetext{
${ }^{432}$ Grossman “American Jewish Communal Affairs” (2000), p. 236.

${ }^{433}$ Ibid, pp. 239-240. Also see Julie Weiner, "YU Confronts Fault Lines of Modern Orthodoxy.” Jewish Telegraphic Agency, 20 March 2001.
} 
husbands' refusal to give them a religious divorce decree. ${ }^{434}$ In addition, some 1,500 people gathered in February 1999 for the first conference of Edah, a group led by Rabbi Saul Berman, a scholar who sought to promote modern Orthodox values within traditional Jewish law, including dialogue with non-Orthodox groups, feminism, and taking various public policy stands. ${ }^{435}$

Another response was the forming in the late 1980s and early 1990s of the Union for Traditional Judaism (UTJ). It brought together a small number of Conservative rabbis concerned with their movement's shift to the left - as seen in the ordaining of women - and Orthodox rabbis concerned with the move to the right of Yeshiva University.

\section{V.10 The Impact Of The Camp David Failure}

While the religious shifts were understandably incremental over the years, there was nothing slow about American Jewry's near unanimous response to the failed Camp David II summit in July 2000. Many American Jews - particularly with the intense general media coverage - anxiously anticipated a positive outcome of the event, despite warnings from American negotiators leaders that a breakthrough was far from guaranteed.

After the summit, Jewish organizations went into high gear, briefing top leaders, strategizing how to respond, and sending out information/analysis e-mails to the rank and

\footnotetext{
${ }^{434}$ Saundra Mandel, "Successful Conference Spawns New Orthodox Feminist Alliance.” Jewish Telegraphic Agency, 4 July 1997.

${ }^{435}$ Mandel, "Modern Orthodox Find Community Amid Struggle to Define an Identity. " Jewish Telegraphic Agency, 16 February 1999. Edah created an on-line journal called Edah Journal. A sample of articles in the first edition included "Reflections on the Possibility of Interfaith Communication in Our Day" and “"Ones Possessed of Religion': Religious Tolerance in the Teachings of the Meiri."
} 
file. A prime technique was to use long-cultivated local media contacts to insure that the American public would perceive that Arafat - not Barak - was behind the summit's failure, a notion that dovetailed well with Clinton's final words on that subject. One integral part of the message to Jews, as Phil Baum of the American Jewish Congress said, was that Barak's refusal to give the Palestinian leader everything he demanded showed that "he is just as careful about Israel's security interests as anybody else.",436

Not surprisingly, the largest American Jewish religious organization, the Reform movement's Union of American Hebrew Congregations, expressed both the disappointment in the effort's failure as well as firm belief that negotiations would ultimately lead to a peaceful solution because the negotiations were irreversible. ${ }^{437}$ M.J. Rosenberg of the Israel Policy Forum sought to reassure followers by comparing the Mideast peace process to that of similar efforts between Great Britain and Ireland when it came to Northern Ireland. That conflict seemed to be coming to a peaceful end thanks to U.S. mediation. ${ }^{438}$

On the other side of the spectrum, the ZOA put out a 48-page pamphlet that was a collection of articles on the dangers of the peace process. In it, prominent American and Israeli officials such as Natan Sharansky, U.S. Senator Jon Kyle (R-Ariz.), American

\footnotetext{
${ }^{436}$ Besser, "Lemon From Lemonade: American Jewish groups put the spin in high gear in the wake of the Camp David failure." Baltimore Jewish Times. 28 July 2000, p. 26.

437 “Nation's Largest Jewish Organization Reacts to End of Camp David Summit." Union of American Hebrew Congregations. Press release. 25 July 2000.

${ }^{438}$ M.J. Rosenberg, “Winners And Losers?” IPF Friday \# 7, 22 July 2000. Web 12 July 2009. The socalled Good Friday Accord was signed on April 10, 1998 by the British and Irish governments, most Irish political parties, and was passed by a referendum of the Northern Ireland's citizens. It was negotiated by former Sen. George Mitchell, whom President Clinton and then President Bush pressed into service to try and get the Mideast peace talks back on track after the outbreak of the Second Intifada.
} 
journalist A.M. Rosenthal and others made their case against Arafat in two to three page articles intended for further distribution. ${ }^{439}$

For its part, the ADL put on its website an extensive briefing entitled "Camp David II: The Aftermath.” It began by supporting President Clinton's notion of Barak's showing "particular courage and vision" while noting Arafat "failed to demonstrate a flexibility or willingness to compromise." Yet, it ended on a hopeful note about how all sides said negotiations would continue, although "a final status agreement is by no means assured."

\section{V.11 American Jews and the Al-Aksa Intifada}

Yet it was not until the outbreak of the Second Intifada that a real crisis mode kicked in for American Jewish organizations and leaders. Suddenly, domestic Jewishidentity building programs were again competing with the need to defend an embattled Israel. The United Jewish Community's General Assembly program in early November 2000 was the first major gathering of American Jewish leadership since the lateSeptember renewed violence. The conference, which in the past few years had been a battleground for religious pluralism between Netanyahu and much of American Jewry, was transformed into a three-day pro-Israel rally for some 4,500 leading volunteers, college students and Jewish organization professionals - the largest crowd yet in the G.A.'s history. That caused a quick refocusing of the planned programming on "learning and what it means to be a Jew today in all its diversity," noted UJC spokeswoman Gail

\footnotetext{
439 Jerusalem In Danger, (New York: Zionist Organization of America, 2000).

440 “Camp David II: The Aftermath,” Anti-Defamation League, 27 July 2000. Web. 12 July 2009.
} 
Hyman. Israeli Prime Minister Ehud Barak added emphasis to the sense of siege when he said in his G.A. address, "We are together at a fateful moment for our people. The times we are in will not only test our unity and faith as a people, but our wisdom as well." ${ }^{441}$

A few weeks earlier, on October 29, about 300 American Jewish leaders had taken off for Israel on a 60-hour solidarity visit with the Jewish state, an event run under the umbrella of the President's Conference and coordinated by the Jewish National Fund. They were part of some 1,000 Diaspora Jews - from Canada, France, the United States, and several major Jewish organizations such as the Jewish Agency for Israel - whose leaders had come to Israel to show their solidarity. While in Israel, the JNF-led group met with everyone from Barak to Netanyahu (who was now considering a political comeback), numerous military officials, and leading army officials at an Israel Defense Forces base at Gaza's edge. Driving home the reality of how Israel had changed, while en route to the Jerusalem suburb of Gilo, the group's busses had to turn around as residences there came under sniper fire from Palestinians in the adjacent village of Bet Jalla. Likewise, from October 18-20, some 50 top Jewish Federation professionals and lay leaders, representing 30 North American communities, undertook a similar trip. American Jewish leadership was reengaged with an Israel under attack - a familiar role for them, despite the seven-year lull of negotiations that periodically brought thoughts of the serious possibility of peace between Israel and her most truculent foes. ${ }^{442}$

\footnotetext{
${ }^{441}$ Julie Weiner, “Israel Returns to G.A. Spotlight.” Jewish Telegraphic Agency, 1 November 2000.

${ }^{442}$ Jerusalem Post Staff. "1,000 Here On Lengthy Support Mission,” Jerusalem Post. 31 October 2000, p. 4. Also see Chaim Chessler, "Solidarity - At All Times," Jerusalem Post. 30 October 2000, p. 6; Jerusalem Post Staff, "Solidarity Missions March to Western Wall," Jerusalem Post. 1 November 2000, p. 2; and Rubin, "Standing With Israel: Baltimore's presence on whirlwind national solidarity tour of Israel is strong." Baltimore Jewish Times 10 November 2000, pp. 42-43, 56.
} 
National and local Jewish organizations picked up the unity theme around Israel with programming, rallies, letter writing campaigns, and meetings with politicians. ${ }^{443}$ With news of daily attacks on citizens of the Jewish state, for the most part American Jewish leaders from across the spectrum publicly said this was no time to express differences on final status issues. Indeed, by late October American Jewish leaders were on almost daily conference calls jointly discussing their own policies as well as potential joint initiatives. ${ }^{444}$ Some were even willing to publicly change their tune. The American Jewish Congress even took out a full page advertisement in The New York Times in which it declared "It Takes a Big Organization to Admit It Was Wrong." 445 Rabbi Eric Yoffie of UAHC, a leader of the Jewish peace camp and himself a former head of the Association of Reform Zionists of America, dramatically declared in a June 1, 2001 speech at a national UAHC board meeting in Cleveland, Ohio:

We have been wrong about some very important things... We misjudged Palestinian intentions and misread Palestinian society. We failed to insist that steps be taken to reduce incitement against Jews and Israel. And we were inclined to focus overly much on the hard choices we had to make, and not enough on the hard choices that our Palestinian neighbors had to make. ${ }^{446}$

Despite the ongoing violence, and the sinking realization that it would not end any time soon, the UAHC joined other American Jewish groups in rededicating itself to

\footnotetext{
${ }^{443}$ Shani Itzkowitz, “At One With Israel: Thousands gathered at Chizuk Amuno last week to express their solidarity with Israel.” Baltimore Jewish Times 27 October 2000, p. 10, p. 12.

${ }^{444}$ Besser, "The Hope Deficit: American Jewish leaders are left wondering what message to offer the rank and file about Israel." Baltimore Jewish Times. 27 October 2000, pp. 36-37. See also by Besser, "Crisis For Left, Right, Center: Each part of American Jewry’s pro-Israel spectrum needs new directions." Baltimore Jewish Times. 12 October 2000, p. 25, p. 39.

445 Grossman, “Jewish Communal Affairs” (2001), p. 247.

${ }^{446}$ Eric Yoffie, "The Masks Are Off: Palestinians, Israelis, And The Problem Of Peace." Remarks to the UAHC National Board Meeting, Cleveland, Ohio. 1 June 2001. Web. June 182009.
} 
defending Israel's good name while holding out the possibility for the return to dialogue. In fact, using a large grant from the Ford Foundation, it launched the "Seeking Peace, Pursuing Justice Program," which was designed to "mobilize North American Jewry to support peace and justice in Israel." The effort was spread out over three years and had $\$ 500,000$ in funding. The goal was to produce materials for the movements' 900 congregations and 1,700 rabbis. The materials were intended to encourage U.S. Jews "to examine the real risks and potential rewards of peace for Israel, the United States, and Israel's neighbors, and to undertake critical, constructive public dialogue on the most pressing issues facing Israeli society — including the status of Israeli Arab citizens and other minorities, and other issues of inequality and discrimination in Israel today."447

Meanwhile, Federation campaigns pumped up the "Israel under attack" line in their annual campaigns and programming. In the first annual campaign after the outbreak of the Al Aksa Intifada - the 2002 one, which ran from July 2001 to June 2002 - the UJC launched an Israel Emergency Campaign to raise at least $\$ 175$ million. $^{448}$

Yet, when it came to actually showing up in the State of Israel, many American Jews far from fulfilled the desires of Israelis. Every major provider of trips to Israel, particularly Jewish youth organizations, saw their numbers plummet as the violence went on. In fact, in the year 2000 some 9,417 youth (not including Birthright Israel participants and students in long-term yeshivah/seminary programs) went to Israel. By the end of the

\footnotetext{
447 “Reform Jewish Movement Launches Major Mideast Peace \& Justice Initiative.” Union of American Hebrew Congregations. Press release, 4 December 2000.

${ }^{448}$ Danny, Ben-Moshe, “The Impact of the Al-Aqsa Intifada On Israeli-Diaspora Relations.” Israel Studies Forum 19.3 (2004): 31, citing Jerusalem Post Internet Edition, 15 October 2002. The 2001 campaign, which began in mid-2000, did not incorporate the Second Intifada into its planning.
} 
next year, the number had dropped to 1,977. In 2002, it fell even lower, bottoming out at 973. ${ }^{449}$ The Reform movement went so far as to cancel its summer 2001 trips to Israel, outraging both Israeli leadership and many other American Jewish organizations. ${ }^{450}$ American Jews were also dragged into the Israeli debate over the fate of Jerusalem, particularly as the fate of Har Habayit/Haram al-Sharif continued to feature prominently in the ongoing Israeli-Palestinian talks. On January 8, 2001, a massive rally in Jerusalem - wide ranging estimates put participants at between 100,000 to 400,000 -saw Jews surround the walls of the Old City, pledging their loyalty to the "eternal, undivided capital" of the Jewish people. Moreover, they were led by Natan Sharansky, a former Soviet refusenik who remained popular among American Jews for his valiant fight against the Soviet system in the 1970s and 1980s. Sharansky, who arrived in Israel in 1986 during a U.S.-engineered prisoner swap/spy exchange, had become leader of the Yisrael B'aliyah Russian-based political party and a prominent cabinet minister during Netanyahu's term. A few weeks earlier, Sharansky had come to the United States to help raise funds to pay for the rally. While there, he spoke to the President's Conference, asking it to be an official sponsor of the event - an offer the group declined due to lack of consensus. Still, he found a willing backer in President's Conference head Ron Lauder, who agreed to speak at the Jerusalem rally much to the consternation of some fellow

\footnotetext{
${ }^{449}$ Ibid, p. 43. The trend was similar from Canada, the United Kingdom, Europe, and South America.

${ }^{450}$ Eric Yoffie, "We Don't Make Political Statements With Children: Remarks to the UAHC Board of Trustees on the Suspension of Trips to Israel." 2 June 2001. Web. 22 July 2009. Also see Michael J. Jordan, "For Reform Head, Nixing Israel Trips Is Just Latest Controversy." Jewish Telegraphic Agency, 15 June 2001. Web. 16 July 2009.
} 
President's Conference members. ${ }^{451}$ Lauder was told that since the group had no consensus on his participation, he had to stress that he was appearing as an individual. Yet, Israeli and other news reports identified him as head of the Conference, much to the anger of groups such as the Association of Reform Zionists of America. ${ }^{452}$

With violence continuing and peace talks still ongoing, Barak was now seen by nearly everyone as grasping for a political miracle that would keep him in office after Israel's February 6 election. As such, he had worn out his enthusiastic greeting from American Jews from 18 months before. The ADL's Foxman noted that Barak, now a caretaker prime minister, was "stretching his mandate" in the ongoing peace talks. Rabbi Seymour Essrog, head of the Conservative movement's Rabbinical Assembly, a group that usually supported Israel's government, warned that compromise on the Temple Mount was something that could "explode the difference between secular and observant Jews in [the United States]."453

Finally, if only a year earlier Likud Party leader Ariel Sharon - nicknamed "the bulldozer" for his often boisterous, past non-compromising comments and actions- had been anathema to many American Jews, by late fall of 2000 he was emerging as the favored candidate in Israel's next elections both in Israel and by many Jews abroad. In no small part, this was due to a sense that Barak had failed to forcefully deal with the uprising and continued negotiating in the face of mounting violence. When Sharon won

\footnotetext{
${ }^{451}$ Deborah Sontag, "Huge Rally In Jerusalem Protests U.S. Proposal to Divide Sovereignty." New York Times. 9 January 2001.

${ }^{452}$ Besser, “The Great Divide.” Baltimore Jewish Times. 12 January 2001, p. 30.

${ }^{453}$ Besser, "Soul Battles: American Jews wrestle with their role in keeping Jerusalem and its Old City united under Jewish rule.” Baltimore Jewish Times. 5 January 2001, p. 41.
} 
convincingly, American Jews knew they had a new challenge: They had to sell to the American public a figure who brought with him a truculent image most recently reinforced by his visit to the Har Habayit/Haram el-Sharif. ${ }^{454}$ After all, even the hardtalking Netanyahu seemed more palatable to some in that he had given up 80 percent of Hebron and agreed to a 13 percent further withdrawal from the West Bank.

\section{$\underline{\text { V.12 Media Monitoring }}$}

A particular front that opened for U.S. Jewish activism because of the renewed violence was media monitoring to ensure that Israel's story was being fairly presented, if not over emphasized, by U.S. news organizations. In conducting these campaigns, e-mail and the Internet - not available to the general public at the start of the first intifada -were integral tools. ${ }^{455}$

In fact, for some American Jews, it seemed as if they decided their role in the battles faced by Israelis would be in waging energetic campaigns in the United States to insure pro-Israel coverage. Some even launched boycotts of prominent publications such as The New York Times, saying that a recent interview with a masked terrorist was far too sympathetic. A similar boycott was announced regarding the Washington Post. Yet, the once united wall of pro-Israel activism seemed irreparably cracked as some major

\footnotetext{
${ }^{454}$ As Lewis Roth of Americans for Peace Now put it, "I think Sharon will be a tremendous public relations challenge for Israel." Dexter Filkins, "The Sharon Victory: Support Mixed With Concern Among U.S. Jewish Groups.” New York Times. 7 February 2001. “ Also see Besser, "Selling Sharon.” Baltimore Jewish Times 9 February 2001, pp. 34, and "Charm Offensive." Baltimore Jewish Times 16 February 2001, pp. 3839.

455 David Herz, "Staying Informed: The Internet allows for up-to-the-minute information on the Mideast crisis.” Baltimore Jewish Times. 20 October 2000, p. 32.
} 
leaders, including Reform movement's Eric Yoffie, noted, "It's not a good idea to make the media the major enemy here."

Right-wing Jews in particular in local communities organized protests, such as against WYPR Radio Station in Baltimore. ${ }^{457}$ One national coordinator of such efforts was the Boston-based Committee for Accuracy in Middle East Reporting (CAMERA), which had been founded in $1982 .{ }^{458}$ It both lobbied mainstream media as well as Jewish newspapers, asking the latter to be a partner in exposing bias amongst local media. NPR nationwide and $\mathrm{CNN}$ were particular targets, which led to the distribution of bumper stickers that read "CNN Lies" and derisively calling NPR "National Palestine Radio." Another group, HonestReporting, was formed by a handful of British Jewish university students in October 2000. In mid-2001, it had opened a U.S. office, which was followed by a Canadian one. Since 2001 it has offered "Dishonest Reporting" Awards. ${ }^{459}$

On a handful of occasions, there was merit to the complaints, albeit they seemed to come more from human error than malicious journalistic behavior. One incident

\footnotetext{
${ }^{456}$ Peter Ephross, “Times Boycotts Launched.” Jewish Telegraphic Agency. 7 May 2001. Web. 5 August 2009.

${ }^{457}$ Jacob Berkman, "Rallying The Troops: Protesters charge anti-Israel bias against The Sun." Baltimore Jewish Times. 20 October 2000, pp. 28-29. Anthony Brandon, President of the WYPR Radio Station conducted private meetings with local Jewish leadership to make his case. National WYPR President Kevin Klose held a private dinner with six editors of leading Jewish newspapers during the June 2001 American Jewish Press Association annual convention. Also see Rubin, "Faulty Print, Frayed Footage: Is the media really biased against Israel, or is it just a product of its limitations?" Baltimore Jewish Times. 27 October 2000, pp. 29-31.

${ }^{458}$ CAMERA released numerous reports, press releases and opinion columns on a wide range of newspapers, TV stations, radio broadcasters and individual journalists. An electronic archive of the reports is at www.camera.org .

459 The operation also offers an electronic archive of media monitoring academic studies from 2001 that have appeared in reputable publications such as the American Journalism Review, Communication Journal, Columbia Journalism Review, and Jewish Political Studies Review. For more, see <http://www.honestreporting.com/a/mediaBias.asp>.
} 
prominently noted by pro-Israel media critics came in the first days of the Al-Aksa Intifada. An American Jewish student in Jerusalem, Tuvia Grossman, was traveling toward the Western Wall for Jewish New Year prayers. After being dragged from a cab, he was stabbed twice and beaten. A subsequently graphic Associated Press photo of the event -showing a battered Grossman on his knees, blood dripping down his forehead -ran in newspapers around the world with a caption misidentifying the Chicago resident as a Palestinian on Har HaBayit/Haram al-Sharif. The error was quickly admitted and corrections were sent out, which ran in most papers; as is standard they were not nearly as prominent as the original article and thus made little impact. ${ }^{460}$

Meanwhile, the World Wide Web, which had only begun being available commercially on a wide scale within the past decade, became a major factor in spreading news both internally via e-mails and organization websites. Nearly every group had a freely accessed website in which it sought to guide adherents and occasional visitors to that group's understanding of the news. The websites often included many links to sympathetic articles from an array of publications, addresses of elected officials to contact, and talking points to use with colleagues and neighbors. Were they interested in getting unfiltered news from Israel, American Jews and others could turn to English language websites from Israeli newspapers $\mathrm{Ha}$ 'aretz, Yediot Acharanot and the Jerusalem Post. Meanwhile, operations such as Israel National News - originally only a

\footnotetext{
${ }^{460}$ Robert D. McFadden, “Abruptly, a U.S. Student In Mideast Turmoil's Grip.” New York Times. 7 October 2000.
} 
radio station in Israel - focused on items of interest to the right-wing sentiments of West Bank/Gaza Jewish residents and their sympathizers, particularly in the United States. ${ }^{461}$

Also, there was hostile competition in English when it came to spreading the antiIsrael word on the Internet. In 1996, the oil-rich kingdom of Qatar in the Persian Gulf had set up Al Jazeera, an Arabic television broadcasting network with an extensive English and Arabic website. A professionally run station, one of its major focuses was the ArabIsraeli conflict and it offered a website reflecting its TV coverage. In particular, its live talk shows gave a platform to anti-Israel spokesmen to spread their influence around the Arab world, which was in turn creating dissension in Arab capitals for pro-western governments such as Egypt. ${ }^{462}$

As is often the case, American rabbis were in a better position than most Jewish organizational leaders were to impact the thoughts of large numbers of American Jews. A study on the American rabbinate, "Rabbi Engagement With The Peace Process In The Middle East," offered both the expected and a surprise. Taken in September 2000, just after the collapse of the Camp David Talks but before the Al-Aksa Intifada, it confirmed the divergence between more traditional and more liberal rabbis on the peace process. Yet, it also showed a deeply pessimistic outlook on the topic.

When asked if they agreed that "Israel and the Palestinians will achieve lasting peace in the near future," only 17.9 percent of Reform rabbis agreed; 12 percent of Conservative rabbis and 11.4 percent of Orthodox rabbis concurred. Those numbers, in

\footnotetext{
461 The news services can be found, respectively, at: haaretz.com, ynetnews.com, jpost.com, and israelnationalnews.com.

${ }^{462}$ Eric Silver, "'Arab CNN': A 24-hour Mideast television news station soars in the wake of the second intifada." Baltimore Jewish Times. 8 December 2000, p. 38. Al-Jazeera's website in English is <www.aljazeers.com>.
} 
such a close range, reflected little optimism in the American rabbinate as a whole.

Likewise, there was near unanimity on the position of moving the U.S. embassy to

Jerusalem (78.2 percent of all the rabbis agreed). However, when read the statement

"Israel should not be willing to dismantle Jewish settlements in the West Bank," 17.9

percent of Reform rabbis agreed, which is surprisingly high considering the Reform

movement's long-time embrace of land for peace. Meanwhile, 19.1 percent of

Conservative rabbis agreed, and 59.8 percent of Orthodox rabbis agreed. Overall, 28.2

percent of the rabbis agreed that Israel should not need to take down West Bank

settlements. $^{463}$

\section{V.13 Breakdown of Ties With American Arab Groups}

Ties between American Arab and American Jewish groups had languished from 1996 to 1999 as tensions in the peace process grew. Barak's arrival did not diminish this trend even before the outbreak of the Second Intifada. In fact, Disney World - an international symbol of family vacations and escape from the modern world's woes became a verbal battleground as Arab Americans pressed their cause upon the American public that Israel's position was not necessarily the valid one. In September, Arab American and Muslim groups (joined by the Arab League) called for a boycott of Walt Disney, Inc. - which would include theme parks around the world, movies and

\footnotetext{
${ }^{463}$ Anan Edward Sokhey and Paul A. Djupe, "Rabbi Engagement With the Peace Process In The Middle East," 1 July 2005. Web 24 July 2009. The rabbis polled were selected randomly from membership lists of the four major American Jewish rabbinical associations, representing the Orthodox, Conservative, Reform, and Reconstructionist movements. About 1,600 rabbis -- half the ones in these movements - were randomly selected to participate. After three mailings, 517 rabbis fulfilled the poll's initial requirements, but only about 400 eventually participated. Rabbis from the Reform movement form a slight majority, roughly corresponding to their percentage of the American pulpit rabbinate. The data is weighted to reflect the proportion of the rest of the rabbis regarding their percentage of the American rabbinate.
} 
paraphernalia displaying Disney's internationally recognized characters. Their concern centered on an Israeli exhibit at Disney’s EPCOT Center in Orlando, Florida. The \$8 million project ( $\$ 1.8$ million of that funded by the Government of Israel) intended to depict Israel's history by using cutting-edge Israeli technology. The Arab groups balked at the display of Jerusalem as Israel's capital. Despite Disney's protest that the exhibit was apolitical, the Arab groups did not budge. Ultimately, a compromise was worked out where Israel made some slight changes. Meanwhile at the exhibit's opening Eitan BenTsur, Israeli director general of the Foreign Ministry, referred three times to "Jerusalem, the capital of Israel.",464

Certainly not helping the cause of American Jewish-Arab relations was the aggressive campaign of the ZOA's Morton Klein to overturn the appointment of Joseph Zogby - son of prominent Arab American James Zogby ${ }^{465}$ - as special assistant to the U.S. Secretary of State for Near Eastern Affairs Martin Indyk (who would in November 1999 become Ambassador to Israel for the second time). Before coming to the State Department, the younger Zogby had published two letters comparing Israeli behavior on the West Bank to the South African apartheid regime as well as criticized U.S. support for Israel. Then in July, House Minority Leader Richard Gephardt was forced to rescind an offer to California Arab-American activist Salam al-Marayati to a spot on the National Commission on Terrorism. The Los Angeles resident had made comments in the past that seemed to condone Palestinian terrorism against Israelis. While local Jewish groups

\footnotetext{
${ }^{464}$ Richard Foltin, "National Affairs," American Jewish Yearbook 2000. (New York and Philadelphia: The American Jewish Committee and The Jewish Publication Society, 2000), pp. 158-159.

${ }^{465}$ Zogby was head of the Arab American Institute.
} 
backed the Arab-American's appointment, they found themselves pitted against their national parent organizations. Marayati eventually did not get the appointment. ${ }^{466}$

Meanwhile, in a move highly disturbing to American Jewish groups, 11 Arab American and Muslim American groups began a campaign to bring light to the "imbalance" of American Jews working in the State Department, including in senior foreign-policy positions. ${ }^{467}$ James Zogby said he felt uncomfortable raising the issue, but that an "imbalance that exists" because "it appears that Arab Americans are excluded from policy positions in the administration." This outraged American Jewish groups who responded strongly to what ADL national director Abraham Foxman called "crude antiSemitism" as it implied that the views of American Jews were antithetical to America's foreign policy goals. ${ }^{468}$

Also, on October 13, 2000 more than 10,000 U.S. Arabs and Muslims protested against Israel in front of the United Nations and Israeli consulate. At the time, Khalil Jahshan, vice president of the American-Arab Anti-Discrimination League candidly admitted that there was no longer systematic dialogue. That also went for areas such as metropolitan Detroit, which had long standing ties between the two communities. ${ }^{469}$

Sadly, about the only thing American Jewish and Arab leaders could agree on was that they did not want the violence in the Middle East spreading to their communities in

\footnotetext{
${ }^{466}$ Grossman, "Jewish Communal Affairs” (2000)), p. 235.

${ }^{467}$ Ironically, many Jews had historically criticized the "Arabists" in the State Department.

${ }^{468}$ Ibid, pp. 169-170. As noted, American Jews were key figures in the Clinton administration's Mideast peace team, where top spots were held by Sandy Berger, Dennis Ross, Aaron David Miller, and Martin Indyk.

${ }^{469}$ Yigal Schleifer, "U.S. Jews Mourn the Absence of Dialogue With Arab Americans." The Jerusalem Report. 6 November 2000, p. 5.
} 
the United States. That came in the wake of a Yom Kippur firebombing at Adath Israel Synagogue in Riverdale, N.Y and an early morning fire set by an arsonist at Temple Ohev Shalom in Harrisburg, $\mathrm{Pa}^{470}$

With the outbreak of the Second Intifada and the Oslo process now seemingly more about saving a remnant of hope than making progress, official conversation between American Jews and Arabs about their mutual hopes and goals seemed at an end.

\section{V.14 A Changed American Jewry}

The breakdown of American Jewish/Arab ties was one facet of an American Jewish community markedly different at the start of the Al-Aksa Intifada than in the beginning of the Oslo years (and particularly the Madrid Process). Despite the increasing inward turn of the overall community, some American Jews and their leaders had made real progress since the June 1992 election of Yitzhak Rabin in the effort to set up a framework of advancing the community's relationship with an Israel at peace. Yet, by the end of the 1990s American Jewry had spent about a decade honing its "continuity agenda." It called for a building of Jewish identity at home, particularly among children and young adults. The hope was that this would reduce assimilation and the disturbing trend of children of intermarried Jews having dramatically lower Jewish affiliation rates than the offspring of endogamous unions. In addition, American Jewry was adjusting to

\footnotetext{
${ }^{470}$ Rona Hirsch, "Call To Arms? Jewish and Arab-American leaders discuss the possibility of violence spreading to their communities." Baltimore Jewish Times 13 October 2000, pp. 32-33. Adding to the anxieties of American Jews were several similar attacks in Europe, particularly in France where several synagogues were firebombed and the Chief rabbi of Paris informed his followers to wear baseball caps and not kippot in public, lest they be harassed by radical Moslem immigrants and their children.
} 
the trend of cultivating spirituality, which was often a personal - not a communal experience.

That's not to say that a connection to Israel dropped off the planning table for American Jews, their synagogues, and their organizations. Indeed, time spent in Israel as a means of enhancing one's Jewish identity was a proven stimulus of Jewish identity. As a result, projects such as Taglit-Birthright Israel gained substantial backing. In fact, the effort's funding mechanism signaled a major change in Jewish life. Having an equal amount of finances come from "mega-philanthropists," the North American Jewish federations, and the Government of Israel was a first. It signified a maturing of the relationship between the Diaspora and Israel (even though two of the three partners were primarily North American Jewish leaders). The bottom line: Israel was no longer seen solely as a charitable cause; indeed, both Prime Ministers Netanyahu and Barak reinforced that message during their addresses to the United Jewish Community's General Assembly meetings and at other forums.

Still, it was innovation in cultivating Jewish identity that was on the minds of most American Jews. So programs to reenergize synagogues arose as did new efforts for non-degree Jewish study in academic settings. Private foundations helped spur this, pumping hundreds of millions of dollars into a number of new non-Orthodox day schools, existing ones and adult education initiatives. Hillels across the country helped bring a higher profile to Jewish life on college campuses (including being a key promoter of the Birthright Israel program). Jewish summer camps, too, began gaining more attention and funding. 
For his part, at the end of the 1990s Ehud Barak would bring both strengths and weaknesses to the inevitable impact any Israeli prime minister will have on the DiasporaIsrael relationship. On the one hand, he provided continuity for American Jews to the powerful figure of Yitzhak Rabin as an Israeli warrior turned peace maker. Rabin, particularly in his tragic death, had been lionized by many as one whose mantle for daring peace moves - albeit with Israel's long-term security at the core -- needed to be fulfilled. Since Barak was Israel's most decorated soldier ever, his claim that far-reaching compromises on once unapproachable red lines would not endanger the Jewish state seemed plausible to many. "If he of all people thinks it's doable," went the thinking, "we should trust him." Barak, who understood that the United States was his best partner in forging an Israeli-Palestinian peace, felt that peace with immediate neighbors would allow the Jewish state to focus on long-range existential threats such as Iran, which funded Hamas and Hezbollah, not to mention had an increasing desire for nuclear weapons.

Of course, vociferous disagreement came to Barak's peace moves as well, particularly from Orthodox Jews and secular groups such as the Zionist Organization of America and its boisterous leader Morton Klein. Yet, polls repeatedly showed that they were a minority - albeit a loud one -- in the overall community, particularly in Barak's first year in office.

The Israeli leader also gained the initial trust of many American Jews by saying the right things when it came to how most of them favorably viewed Jewish religious pluralism and Jewish unity. As a result, he was greeted during his first few trips to 
Washington with great regard and high hopes by both Clinton administration officials and most American Jews.

On the other hand, Barak's overly confident personality that drove him to seek to control the pace and content of negotiations - enhanced by the Clinton administration's deferral to him - increasingly alienated White House officials. Meanwhile, Barak did little if anything to reach out to American Jews. This pattern differed from that of his immediate predecessors, who periodically sympathized with the concern over the waning of American Jewish identity. Indeed, it seemed that Barak simply could not speak about internal American Jewish concerns. That's not necessarily surprising in that he was more removed from Jewish tradition and American Jewry than any previous Israeli prime minister. Rabin and Peres had long-standing ties to American Jewish leaders and groups; the partially U.S.-educated Netanyahu came from a family steeped in classical Zionist ideology, which included a respect for Jewish tradition despite not specifically adhering to it. Barak, however, was a secular Jew through and through. His background was military, not diplomatic. He had no practical experience in dealing with Diaspora concerns. He did not speak of Jewish identity and continuity. Rather, he discussed strategic threats and military capabilities. The best he seemed to do in understanding American Jews' connection to the State of Israel was to tell them that they must unquestionably follow his lead in the peace talks and that they could invest in Israeli businesses and make money. In other words, do not see Israel as a charitable cause but as a place for financial gain.

Still, the intensely powerful connection to the Jewish state did not ebb amongst American Jewish leadership. After the failure of the Camp David talks, the American 
Jewish groups wasted no time in publicly defending Barak's positions. After all, Clinton was leading the way for them with his praise of the Israeli leader at the summit's final press conference. Ironically, the collapse of the talks made defending Israel easier for American Jewish groups. Had Barak given up even partial control of Har Habayit/Haram al-Sharif, the divisions in American Jewish life - reflecting expected tumultuous responses in Israel - would have been accentuated.

So American Jewry, after years of increasing division, seemed at least for the moment to again have a unifying theme to rally around: "Israel was ready for peace, but the Arabs were not." Not surprisingly when the Palestinian violence did come in late September 2000, much of American Jewish leadership easily took to the role of vocally defending the Jewish state.

The problem was that assimilation and individualism had not slowed. In fact, between 1990 and 2001 there was a strong decline in the overall number of Americans who identified as Jews. Not only that, but that smaller number of Jews had organizationally divided themselves more than ever before with the founding and nurturing of an increasing array of Jewish special interest causes. That meant that those active in Jewish life were putting their energies into specific causes, not necessarily large, sweeping ones such as defending an embattled Israel.

Meanwhile, the American Jewish community was understandably disillusioned with talk that the long road to peace was still achievable in the coming years. As a result, again reflecting the concerns of a majority of Jewish Israelis, by the February 2001 Israeli elections many American Jews were welcoming a not-long-ago unthinkable Israeli prime minister: Likud Party leader Ariel Sharon. After all, Sharon had campaigned for and then 
formed a national unity government with the Labor Party (from which Barak took a temporary time out after his electoral loss). ${ }^{471}$

With Sharon's election, a new era had begun. The previous one had started with the most robust efforts toward peace yet amongst Israelis and Palestinians. In the United States, it had spawned American Jewish-Arab cooperation, revealed the depths of the bonds of the U.S. and Israeli governments (and populations), saw the rise of new Jewish organizations, accentuated the shifting of internal priorities, and brought serious efforts to promote an American Jewish identity without Israel at crisis at the core. Now, a much more diverse and much more divided American Jewry faced anew an embattled Israel.

${ }^{471}$ Sharon tried to woo Barak into becoming his Defense Minister, which created opposition within the Labor Party Eventually, Labor's Binyamin "Fuad" Ben-Eliezer, a Brigadier General (Res.) was given the post. Ben-Eliezer served as Labor Party leader after Barak's resignation until Amram Mitzna was elected to the post on November 19, 2002. 


\section{Chapter VI. Conclusions}

\section{VI.1 Lessons for American Jews}

The Oslo era of 1993 to 2000 left an Arab-Israeli conflict with a substantially different reality than prior to the era, new lessons for U.S. government officials due to their unprecedented sustained level of involvement in settlement negotiations, and especially a new reality for ties between U.S. Jews and the State of Israel. Those changes and lessons, this dissertation has shown, can be best understood by analyzing the multiple shifts in American Jewish life during the period under study.

The following presents some conclusions drawn from the research presented in the previous five chapters, beginning with American Jews.

- American Jewry's advocacy for Israel has a better chance of success with both the U.S. government and the general U.S. public when framed in the values of what is best for the United States. In the case of the Oslo years, advancing Mideast peace had already been a long-established element of U.S. foreign policy. It was now strengthened by both the political maturity of the U.S. Jewish community (a backbone of the Democratic Party) as well as being a rising concern of conservative Christians (a core constituency of the Republican Party). Earlier examples of this link between Jewish concerns and national values came with the campaign to bring freedom for Soviet Jewry. That was tied to human rights and freedom of religion. In addition, the commemoration of the Holocaust was linked to both U.S. participation in ending World War II and striving to have a moral element be a feature in U.S. foreign policy, which would hop0efully insure that 
such a tragedy would "never again" occur. As a result, when it came to advocating on behalf of the State of Israel, American Jews intrinsically understood the need to promote a "shared values" agenda as a bedrock of the need for a strong U.S.-Israeli relationship.

- As the continuity agenda advanced, it needed a strong Israel component to prevent American Jews from becoming more isolationist when it came to relating to the world/Israeli Jewish community. The reasons for this were two fold: First, personal experience with the State of Israel was a proven identity builder for Diaspora Jews and thus good for overall Jewish identity. Second, the Oslo years proved that substantial advances can be made in negotiations, but that there is no quick road to Israeli-Palestinian peace. As such, American Jews could not afford to reduce their interest in the Jewish state. That's because events could prove (and did prove) that American Jews would be soon be called upon to defend the Jewish state anew. Thus, was the sense of concern for Israel's well-being weakened, rallying the masses would be more difficult.

- The effort to maintain focus on Israel could successfully be molded to meet domestic Jewish needs. A prime example was the Birthright Israel-Taglit program, which not only brought tens of thousands of young adults to Israel, but gave more relevance (and traffic) to the campus Hillels that coordinated much of the recruiting efforts. Since not all of the participants were college students, American Jewish federations and other sponsoring organizations received contact information about members of a generation increasingly distanced from Israel 
when compared to previous ones. They also were less likely than past generations to forge an adult identity that revolved around Jewish life.

- The need to continue and to cultivate person-to-person bonds between Israeli and American Jews was paramount. That is because while headlines and crises came and went (such as the conversion crisis of 1997-98), maintaining a personal sense of attachment to Israelis was a high motivating factor for both visiting the Jewish state and caring about its fate. The Federation-sponsored Partnership 2000 (P2K), which was preceded by Project Renewal, presented a good example. P2K also marked a maturation of the Israel-Diaspora relationship. Unlike the Project Renewal effort, it gave joint decision making power to equal numbers of community leaders in the United States and Israel regarding how to further the relationship between the two communities. It also included an array of focused exchange visits for groups such as high school students, social workers, educators, community center staff and more.

- American Jews needed to understand that despite such increased personal ties, due to the coalition politics back home, for Israeli leaders it was domestic politics - i.e. staying in power - that shaped how they often responded to situations that could impact world Jewry. That tendency could and did clash with the desires of a majority of American Jews. This was particularly seen in the Netanyahu administration's moving forward with potential changes to regulations on the validity of non-Orthodox conversions. Indeed, despite long-standing ties to the non-Orthodox majority of American Jews, during his first visit to New York City as prime minister, Netanyahu walked in the rain to an Orthodox congregation on 
Shabbat and did not attend a non-Orthodox one, which pleased his Orthodox coalition partners back home.

- With this in mind, just as when acting on behalf of a "shared values" agenda with other U.S. ethnic groups on domestic issues, American Jews were more likely to succeed in advancing their agenda in Israel by partnering directly or indirectly with Israeli advocates that shared their cause. For example, during the conversion crisis, American Jewish religious pluralists capitalized on an issue that had importance in domestic Israeli politics due to the needs of the large immigrant Russian population, up to one-third of whom were not Jewish according to strict interpretations of Jewish law. American Jews naturally teamed up with the Israeli Reform and Conservative movements on this matter as well, but those Israeli groups were minor ones not large enough to influence their country's dynamic political climate.

- American Jews also could influence the Israeli government's policies regarding Jewish religious pluralism if they were willing to publicly challenge Israel's leaders, particularly at high profile forums such as the Council of Jewish Federations (later the United Jewish Communities) General Assembly. These events were heavily covered by national U.S. Jewish, general, and Israeli media. No Israeli prime minister welcomed U.S. or Israeli headlines about American Jewish strife over the Jewish state's policies, particularly with claims that Israel is the world's only democracy where the government discriminated against Jews.

- It was important for American Jewish groups to give voice to Israel's opposition parties at key forums such as the AIPAC annual policy conference. Israel is a 
vibrant, noisy, and complicated democracy. American Jews needed as much exposure to that as possible, which would enable them to understand the possibility of dramatic shifts in Israeli government policies and leadership. Indeed, today's opposition leader may be tomorrow's prime minister, as the experience of Ehud Barak and AIPAC showed in 1999. That means that maintaining good ties to all major Israeli political leaders was important for American Jews to achieve their goal of advancing the state of Israel's desires.

\section{VI.2 Lessons for Israeli Governments}

- The reservoir of support for the State of Israel among many American Jews and their leading organizations was strong and deep. Despite being insulted first by Yitzhak Rabin and his top officials, and then by Barak for not showing 100 percent unified support for controversial Israeli government peace process policies, American Jewry was more than ready and willing to defend the Jewish state upon the outbreak of the Al-Aksa Intifada. In fact, some American Jews and their leaders seemed more comfortable in again fulfilling this historic role, one that had been undermined by the possibility of real peace (particularly in the Rabin era) with the Palestinians.

- Nonetheless, Israeli officials needed to understand that American Jews would not support their every move. That was particularly true when it came to policies that impact the standing of pluralistic approaches to Judaism in the Jewish state. With the separation of religion and state as a bedrock principle of American civic life, Americans - Jews or otherwise - often approached these issues from an entirely 
different perspective than did Israelis. Indeed, for citizens of the Jewish state, Orthodoxy's control over personal status issues was part of daily life. That is part of why the Ministry of Religion (now part of the Prime Minister's office) was always a desired prize of Orthodox parties negotiating to enter a coalition.

- It was important to maintain a dialogue with American Jewish groups on these matters. Appointing a minister or high ranking adviser of the prime minister to such a position sent a welcome signal of concern and engagement to many American Jews. Indeed, after the Rabin assassination Shimon Peres did this with Rabbi Yehuda Amital, a Haredi Orthodox rabbi and peace process supporter. Likewise, Netanyahu put Finance Minister Yaakov Ne'eman, a highly respected modern Orthodox Jew, in charge of creating a compromise during the conversion crisis. For his part, Barak put Rabbi Michael Melchior, also a Haredi rabbi and peace process supporter, in this position.

- American Jewish groups, due in large part to the politically dynamic nature of their community, had disproportionate access and influence to top policy makers. Thus, they could be a conduit for Israeli politicians of messages to American policymakers and could help make the Government of Israel's case in Washington, D.C., which is another good reason why an Israeli prime minister should have been extremely careful when it came to potentially angering American Jews by shifting his country's status quo on religious matters. Likewise, because a number of leading American Jewish organizational volunteer leaders were international business and political figures, they could be used confidentially to create backdoor channels to Arab leaders. In fact, Netanyahu 
successfully used former U.S. ambassador and American Jewish leader Ronald Lauder as a conduit for secret messages to Syrian President Hafez el-Assad.

- For the most part, especially if there was a generally agreed upon goal between U.S. Jews and the Israeli government, the White House would give great leeway to an Israeli leader's desires. This was particularly true, as Barak understood, early on in an Israeli administration's term as well as toward the end of a U.S. administration deeply invested in the success of the peace process. In fact, a large White House state dinner in Barak's honor, held during the Israeli's first trip to the country as Prime Minister, reinforced for the Clinton administration the enthusiastic support of a strong majority of American Jewry for helping Israel pursue the peace process.

- There are multiple levels of support within the U.S. polity for the State of Israel, all of which had to be cultivated carefully due to strains between some of these groups. The strongest example was the obvious base of support from proDemocratic Party American Jews and the pro-GOP Evangelical Christians (often known as Christian Zionists or conservative Christians). Netanyahu, for example, courted the Evangelicals, which angered both the Clinton administration and many American Jews. Most of American Jewry opposed much of the domestic agenda of the Christian conservatives, which included enhancing Christianity's visibility in the public square. The Evangelicals also had long-standing ties to groups that targeted American Jews, particularly young adults, for conversion to Christianity. 


\section{VI.3 An Era of Broad Jewish Shifts}

While those are some of the specific lessons learned during the Oslo years, a broad summary of the era determined that American Jewry underwent substantial shifts during this period. In particular, its organized structure became much more focused on internal needs as it confronted the dilution of American Jewish identity for many; this was widely perceived as threatening the long-term health of the community, which in turn would impact the ability to advocate the pro-Israel agenda.

Still, despite increasingly diverse definitions and options, promoting the proIsrael agenda and deepening personal ties to Israel maintained a primary role on the communal agenda. In fact, even the Birthright Israel experience was positioned as enhancing the Jewish identity of the next generation of American Jews. It was well understood that cultivating the relationship to the State of Israel for its participants was an important part of building the Jewish identity the organized community hoped participants would develop.

At the same time, on the one hand the overall community was shrinking due to increasing assimilation as seen not just in intermarriage statistics, but in the resulting weak Jewish identity of many of the children raised in such families. On the other hand, the overall smaller core community was becoming more intensely ideological, as seen in the formation of new groups and the now standard public attacks on one another's positions on Israel and other matters. Indeed, with the State of Israel considering once unthinkable compromises with the Palestinians and the Arab world, shrill voices on both sides were heard in Israel and the United States. 
By the conclusion of the period under study, with the outbreak of the Al-Aksa Intifada and the slow realization that it had ended the Oslo process, nearly all of the Jewish community's leadership and much of its rank and file were prepared to fight again for Israel in the media (and now on the Internet), in the political world, and in the court of public opinion. But some others now had different interests, Jewish and otherwise. The challenge was compounded by general trends away from both activism and consensus amongst Jews and non-Jews alike. Some of those who identified as Jews sought to build a personal sense of spirituality and identity, which was spurred on by the continuity agenda. That had these people focusing inwardly as well as building the sub-communities of which they had become a part, leaving less time for connecting with broader world Jewish (i.e. Israel) matters.

By the end of the Oslo years, this all left an American Jewish community with the sense that it was fighting on all fronts - on behalf of Israel, on behalf of threatened Jews in Europe (particularly in France), and most of all on behalf of its own well-being in the face of weakening Jewish identity markers and shrinking organizational memberships.

\section{VI.4 How It All Happened}

American Jews, while never more than a few percentage points of the overall U.S. population, successfully used sometimes latent, sometimes overt understandings of mutual interests between Israel and the United States to further ties between the two countries. In doing so the American Jewish leadership strived to insure that its own members, particularly younger ones, continued to feel a deep sense of connection to and 
shared fate with the residents of the Third Jewish Commonwealth. That, however, became increasing difficult by the 1990s as the forces of assimilation (as evidenced by a high rate of intermarriage, decline in organizational membership, and sense of individualism instead of communal collectivism) grew at an alarming rate.

This pattern was occurring despite the increasing financial success of many American Jews, which was bolstering new Jewish identity efforts, as seen in the rise of private Jewish family foundations. The new dollars families and individuals pumped into the system of organized Jewry helped fund large initiatives such as Birthright IsraelTaglit, non-Orthodox Jewish day schools, new social service agencies, expanded campus Hillels, an array of Jewish summer camps, the Partnership 2000 Diaspora-Israeli relationship building program, and a vast array of smaller, local efforts.

Also in this period, American Jews began cultivating alternative forms of involvement in Israeli society that favored financial investment over the traditional notion of charitable giving. One example came through the state run business development offices (which in most venues were funded in part by the organized Jewish community), various youth and professional exchanges, and specialized programs ranging from "adopt a cow" on a kibbutz to funding amenities on Jewish settlements such as playgrounds.

Meanwhile, within American society Jews were experiencing a moment of unprecedented social acceptance (one of the causes for the increased intermarriage rate). An example of this was how being openly Jewish in religious behavior was no longer a barrier to public prominence. This was best symbolized by the 2000 Democratic vice presidential campaign of Sen. Joseph I. Lieberman (D-Conn.). As a candidate, the national board member of the Orthodox Union was so overt in discussing his traditional 
Jewish observance that it was a major Jewish group, the Anti-Defamation League - long a champion of the separation of religion and the public sphere - that gained headlines for chastising him for interjecting personal religious beliefs into the nation's top political race.

\section{VI.5 Shifting Priorities}

Meanwhile, by the early 1990s the major concerns of American Jews were undergoing large shifts. Ever since the nerve-wracking lead up to what would become the 1967 Six Day War, the communal leadership had three unifying items at the top of its agenda: memorializing the Holocaust, advocating the relief and rescue of Jews behind the Iron Curtain (as well as resettling them in Israel and the United States), and lobbying on behalf of the democratically elected government of the State of Israel.

By the second half of 1993, the first two items on the agenda had been achieved. On April 22, 1993, the world's media focused on a politically star-studded dedication of the U.S. Holocaust Memorial Museum in Washington, D.C. The result of 14 years of work by the U.S. Holocaust Memorial Commission started by then-President Jimmy Carter, the privately funded $\$ 168$ million center was formally opened by President Bill Clinton, Vice President Al Gore, Nobel Laureate Elie Wiesel and others. The Museum's high profile venue on the National Mall helped it to quickly become a major attraction in the nation's capital. Likewise, annual Holocaust Memorial events sponsored by the Museum in the U.S. Capital Rotunda - ones mirrored in state houses, government buildings, schools around the country, not to mention numerous small privately funded Holocaust museums - seemed to have cemented the memory of the Shoah in the nation's 
civic consciousness. Finally, Hollywood, that great shaper of the American cultural mindset, embraced projects delving into the Holocaust in the form of acclaimed and highly watched films such as "Schindler's List," which spawned a generation of quality major films that made exploring the Holocaust experience a broadly acceptable theme.

In addition, while the impact of the Holocaust would continue to be a powerful factor in the lives of many U.S. Jews, the community could proudly note that in the physical form of memorials as well as educational curricula taught in nearly every corner of the nation, the Shoah was now remembered and discussed, particularly in the context of how its moral lessons related to current events - such as the Clinton administration's initial reluctance to becoming involved in the Bosnia crisis of early 1993. Thus, the powerfully motivating project of memorializing the Holocaust for both American Jews and non-Jews seemed to have set a permanent foundation in the nation's civic and social weltanschaaung.

Equally successful, but seemingly with much more speed, the hopes of securing free emigration rights for Eastern Europe's Jews was accomplished. This cause progressed rapidly with the massive political changes sweeping through the Soviet Union in the late 1980s under the premiership of Soviet leader Mikhail Gorbachev and then with the formal demise of the USSR on December 25, 1991. One factor in the collapse of the once communist superpower was the crippled Soviet economy, something spurred on in part by the U.S. Congress's Jackson-Vanik Amendment. Its passage and enforcement since the early 1970s had been heavily advocated for by American Jews and their political allies. It made large scale credits to the Soviet Union contingent on relaxing strict Soviet emigration rules (for Jews and non-Jews). 
Through this effort, American Jews had learned a large lesson that would pay off in their pro-Israel advocacy: Framing Jewish interests in generic terms palatable to the broad American public - in this case the freedom of religion and emigration - could be a powerful uniting issue for all Americans. In other words, Jewish political power in coalition with diverse groups could help shape the nation's foreign policy agenda to the great benefit of endangered Jews and other minorities abroad. This "shared values" agenda was always a major factor in advocating for strong U.S.-Israeli ties.

The Soviet Union's disappearance and replacement by successor states (led by the Russian Federation) ended formal barriers to what for several years had already been a strong flow of Jews from Eastern Europe to Israel and the West. As a result, by the end of the 1990s more than one million former Soviet Jews found themselves in new countries. In response to the wave of immigration, North American federations ran special campaigns, raising hundreds of millions of dollars, to help integrate the emigrating Jews and their families around the world, but primarily in the United States and Israel. Meanwhile, the heated debate of the 1970s and 1980s between Israel and the Diaspora Federation system over the noshirim - those who had "fallen out" because they switched in transit their desire to immigrate to Israel to the United States as a destination - was also at an end. That was because the U.S. government had formally stopped granting political refugee status to Eastern European Jews, and the vast majority now went to Israel.

In retrospect, the noshrim fight remained a glaring example of political and priority differences between the American and Israeli Jewish communities. American Jews, reared on freedom of choice as a core value (also a deeply ingrained American 
value), favored emigration to the country of one's choice. By contrast, Israelis wanted the Russian Jews to bolster their demographics and to provide an always needed technically skilled workforce. Likewise, the time-honored strain of American Jews opting to stay put, which defied classical Zionism's desires, was a factor as well. After all, it would be hard to insist that Soviet Jews - some of whom were literally long-lost relatives - had to go to Israel when American Jews themselves continually rejected that long-available choice.

Meanwhile, some Jews would remain in the Former Soviet Union, and there would be a push by American Jewish-funded groups to help them build sustainable communities there. Still, without question the attention of the Federation world and the National Conference on Soviet Jewry (which it funded) turned to helping the immigrants build new lives in the country of their choice. This marked the realization of a several decades long struggle by American Jewry, one that had seen numerous public rallies, b’nai mitzvah twinning projects, college campus awareness campaigns, clandestine trips to the Soviet Union, and more.

The third major agenda item, advocating on behalf of democratic Israel, had also for the most part been a unifying force in the diverse American Jewish community until the 1990s. With the Oslo signing on September 13, 1993, concerns over a strong, safe Israel certainly did not diminish. However, with the real possibility of an IsraeliPalestinian long-term peace in sight, the question as to how to achieve that goal and American Jewry's role along the way became increasingly contentious. That mirrored an even more raucous debate in Israel, one that always impacted the American scene.

That is not to say that since the early 1970s, and particularly since the EgyptianIsraeli negotiations leading up to the 1979 peace treaty between the two countries, that 
cracks had not appeared in the unwritten rule of not publicly criticizing Jerusalem's government. American Jewish groups which promoted left-wing sentiment amongst the Jewish community's positions on the Israeli government's peace moves -- such as Breira, the New Jewish Agenda, and Americans for Peace Now (APN) -- were started, often mirroring similar efforts in the left-wing segment of the Israeli political spectrum.

Still, none of these American groups were considered major players on the country's organizational Jewish scene. Indeed, it would not be until the advent of the Oslo process in mid-1993 when one of them, APN, would be elected to the President's Conference, albeit it in a vote contested by opponents of the emerging peace process. (By then the New Jewish Agenda and Breira had closed shop.) Some groups, keeping with the practice of not publicly criticizing Jerusalem's government, noted that since APN's board contained supporters of Rabin's key coalition partner, the Meretz Party, it would not be right to oppose the membership.

This, too, then offered an important insight into American-Israeli Jewish relations: The composition of American Jewry's top consultative organizational body could be expanded to incorporate the desires of Jerusalem's government. However, such a membership has never been rescinded if Jerusalem's government does not approve of a group. (The membership of vocal peace process critics such as the Zionist Organization of America is a primary example.) There was a cost, however, to this welcoming of new groups such as APN. Since membership in the President's Conference seems permanent, this built a heightened sense of tension into the body's proceedings. That is only because many of these newer members were ideologically based, not the broad-based secular or religious membership operations including veteran President's Conference members such 
as the American Jewish Committee or the Union of American Hebrew Congregations. These newcomers had a single interest, more homogenously based raison'd'etre. This inevitably made compromise or even acceptance of broad positions more difficult for them if the President's Conference proposed policy statements which differed from their specific mission.

\section{VI.6 Jewish Political Power}

At the same time, the overall political position of American Jews seemed to reach new heights in this period. Throughout the decade in which the Oslo process came into being, political appeals to the highly organized and politically dynamic U.S. Jewish community was an undeniable factor in the formation of U.S. policy toward the Jewish state. This was so much the case that an appearance by a major presidential candidate at the American-Israel Public Affairs Committee annual spring meeting was basically mandatory. In fact, it was extremely difficult to imagine that any candidate perceived as anti-Israel by the Jewish and general community could be nominated by the Republican or Democratic parties, let alone win a national election. Likewise, during non-election years the administration and opposition always sent high ranking representatives to the AIPAC conference as well as the Council of Jewish Federations (later the United Jewish Communities) annual General Assembly.

Pro-Israel policies had indeed become such an indisputable bi-partisan feature of the American political scene that even when strains occurred, U.S. officials strove both publicly and privately to assure interested parties that the Washington-Jerusalem bond 
was firm. Any difficulties, it was often asserted, were merely differences amongst friends who shared the goal of the State of Israel's best interests.

This was seen in the contentious relationship between the administration of President George H.W. Bush and that of Prime Minister Yitzhak Shamir during the late 1980s and early 1990s as the latter advocated a West Bank/Gaza Strip settlement building campaign opposed by the former. It also was evident with Bush's ill-worded comments at a press conference on September 12, 1991 regarding his opposition to Israel's request for $\$ 10$ billion in loan guarantees. Within days of the president declaring, "We're up against very strong and effective ... groups that go up to the Hill," he found himself apologizing to Shoshana S. Cardin, the top volunteer leader in American Jewish life, in a letter published by The New York Times even before a private copy reached Mrs. Cardin's house. (By the 1992 election, Bush had learned his lesson the hard way. Mishandling the pro-Israel agenda distracted a campaign with negative national headlines, weakened outreach to the Jewish community, and eroded electoral support.)

The Clinton administration, too, faced challenges in maintaining the appearance of a pro-Israel orientation. While it was extraordinarily close with the Rabin-Peres governments, serious strains developed during Netanyahu's tenure as head of the Israeli government (1996-1999). This stemmed from the slowing down of the Oslo process due to the Israeli's insistence over "reciprocity," which called for full Palestinian compliance - as interpreted by Netanyahu -- on ending media and verbal incitement, and reigning in terrorists and their organizations. Clinton administration officials, despite their private displeasure and what appeared to be Netanyahu's intransigence to move the process forward, continued to go out of their way to reassure the American Jewish leadership of 
their commitment to the State of Israel's safety, which they defined in part as moving ahead with the peace process.

Clinton himself was a powerful symbol regarding the depths of U.S.-Israeli ties. For him, a strong U.S.-Israeli relationship was said to be as personal as it was political. Indeed, the initially unlikely bond he had formed with Rabin seemed to have a profound effect on both American and Israeli Jews. This was best evidenced by his moving response to Rabin's assassination, a murder that had seriously jeopardized the future of the peace process. Then there was the oft-repeated assertion of the U.S. president's childhood preacher that young Bill would one day become the American political leader and that God would never forgive him were he to forsake the State of Israel. Encouraged by this philo-Semitism, Jews as a group (already overwhelmingly supportive of the Democratic Party) enthusiastically supported the Clinton presidency and strongly backed the 2000 presidential bid of Vice President Al Gore, Clinton's anointed successor.

\section{VI.7 Why the Pro-Israel Agenda Matters}

The reasons for the strong bi-partisan pro-Israel sentiment - in addition to the shared values agenda -- were diverse. They include Jewish success in fund raising, providing volunteers, the history of disproportionate Jewish voting in key Electoral College states, and a pro-Israel platform also being important to many non-Jewish voters. The last matter included religious perspectives, indentifying with the only democracy in a region where other countries were often hostile to the United States, and subsequently appreciating the strong U.S.-Israeli military alliance, which could be beneficial in a global conflict. 
When it came to the Democratic Party, despite being only about two percent of the U.S. population in the 1990s (a slow but steady decline for decades), Jews continued to vote heavily for the party's presidential nominees. The importance of these votes was accentuated by heavy Jewish voter turnout in key geographic areas, particularly in the urban centers in which Jews were concentrated. Thus, capturing the enthusiasm of Jewish voters - which could boost turnout and financial contributions -- gained additional importance in the eyes of a Democratic presidential candidate. The best example came in the 2000 presidential elections in which heavily Jewish precincts in central Florida played a role in deciding the election (despite the GOP's Gov. George W. Bush, for whom most Jews did not vote, eventually being declared the winner after complicated legal maneuvering ultimately presided over by the U.S. Supreme Court).

That is not to say that pro-Israel Jews were absent in the GOP. They were, however, a small minority when compared to their Democratic counterparts. Still, while never attracting a majority of U.S. Jewish votes in the $20^{\text {th }}$ century - the greatest gain being the 1980 election in which Ronald Reagan brought in about 40 percent of the Jewish ballots -- the GOP far from gave up courting Jews and from promoting its proIsrael credentials. Prior to the 1990s, much of the reasoning for this was based on Cold War realities of Israel being both western-oriented and the only democracy in a region, which made it a loyal ally were there to be a global East-West conflict. By contrast, for decades most major Arab nations were either non-aligned or outright Soviet allies. This helped to create a generation of pro-Israel policy makers in the Republican Party.

After the Cold War ended with the demise of the USSR in late 1991, the strongly pro-Israel Evangelical Christians, already a factor in GOP politics, were increasingly 
recognized as an important base of the party's electoral support. The Evangelicals - an estimated 60 million to 70 million Americans (almost one in five) -- were as a bloc seen as being as pro-Israel as were American Jews. Evangelicals, however, often took a harder line against Israeli land-for-peace compromises (or any compromises) than did most American Jews. That's because the reasons behind this Christian support for the Jewish state differed from that of American Jews. Indeed, such Christian pledges of help made many Jews nervous due to the role they were slated to play in Evangelical "end time scenarios." That theology featured the death of non-believers in the divinity of Jesus as part of his second coming to the Jewish-ruled Holy Land. It also included great battles which, after much Jewish bloodshed, would begin a millennium of Christian peace, leaving Jews not killed in the battles to worship Jesus as "fulfilled Jews."

Still, despite such bi-partisan support for a pro-Israel agenda, U.S. administrations were not naïve when it came to understanding that there were splits amongst American Jews when it came to defining their pro-Israel stands. As such, they often took into their confidence groups that best fit their own agenda - such as President Clinton inviting representatives of pro-Oslo process groups to meetings in the White House while avoiding Oslo detractors, which of course angered those not invited.

Finally, the pro-Israel agenda benefitted in part due to the disproportionate service of American Jews as elected and appointed officials, natural outgrowths of the community's strong political orientation and participation. While it is unlikely that these individuals could get elected and reelected were they not in sync with their constituents on this and other matters, it also is likely that they were conversant in the Jewish community's concerns with the complicated and nuanced issues of Arab-Israeli 
negotations. Likewise, the presence of high ranking Jews in both elected and appointed positions gave Jewish organizational leaders contacts within the highest ranks of the U.S. government. Sen. Lieberman's being on the board of the OU was a prime example of this.

With such heavy bi-partisan support amongst the electorate and elected officials for a pro-Israel orientation, the U.S. government invariably found itself involved in Mideast peacemaking efforts.

\section{VI.8 The Shock of Oslo}

The APN membership debate at the President's Conference was just one example of a broader explosion of dissent unleashed by the September 13, 1993 signing of the first Oslo Accords (often referred to as Oslo One). Indeed, what it triggered surpassed any previous level of discord among American Jews (which only mirrored the more intense and dramatic debate taking place in Israel). Indeed, the famous Rabin-Arafat handshake opened vigorous and often nasty debate across the spectrum, particularly between nonOrthodox and Orthodox Jewish groups. Some Israeli and American Orthodox Jews eventually condoned the right of refusal for Israeli soldiers when it came to acting against Jewish settlers and increasingly radical acts against those who would relinquish land to Israel's enemies - in this case Rabin and Peres.

Yet, the Oslo process unquestionably had both major positive as well as negative impacts on Arab-Israeli peace making and on the American Jewish scene as well. For Israel, most of the positive gains came in the 26 months that Rabin was at its helm, a period in which Palestine Liberation Organization leader Yasser Arafat - who until 
recently for most American and Israeli Jews had personified Israel's enemies triumphantly returned to Gaza at the invitation of the Israeli government. He was charged with laying the foundations for a peaceful Palestinian entity; there was not yet talk of an independent state by the Israelis, despite the clear Palestinian hopes of that being the end result of the Oslo process.

The results for Israel's relationship with the broader Arab world were quick in coming. They included an Israeli-Jordanian peace treaty the next year and low level ties with numerous other Arab states. In addition, serious peace negotiations were conducted with Syria, which if successful were likely to lead to peace with Lebanon and possibly the entire Arab League. In addition, there was continual cooperation between top Israeli and Palestinian officials in numerous areas, including the critical joint security patrols.

Rabin was an unusual candidate to be at the helm of such a process. His previous term as prime minister (1974-1977), and his subsequent years as Defense Minister, showed him to be a strategic, cautious leader who gave great weight to strong relations with the U.S. government. No doubt this stemmed in part from his years as U.S. ambassador (1968-1972), a period in which he cultivated deep friendships with both leading American Jews and top administration officials. Indeed, during Rabin's period in Washington he saw up close the mechanisms of U.S. diplomatic oversight regarding Israeli-Arab negotiations, in particular with the negotiations leading up to the signing of the Sinai I and Syrian Disengagement Accords, which would bring a formal end to the 1973 Yom Kippur/October War.

Despite Rabin having put so much stock in Israel's relationship with the American government - both the White House and the Congress - he came into office 
with a substantial grudge against the formal apparatus of American Jewry, particularly AIPAC. This reflected a flaw in understanding of American Jewry by Rabin, one that would be echoed in Barak's behavior as well in the late 1990s. Since the 1977 elections, which for the first time brought the party of opposition Likud Party leader Menachem Begin to power, Israel had been ruled or co-ruled by Likud governments (including the 1984-88 national unity government with the Labor Party in which Labor's Peres ruled as Prime Minister from 1984-86 and Likud's Yitzhak Shamir was his Foreign Minister, after which they swapped places). Thus, for 16 years American Jewry and U.S. governments had adjusted to governments headed or co-headed by adherents of the Greater Israel philosophy, which rejected the "land for peace" formula on which the Oslo process would be built.

It would be unexpected and unnatural for a generation of American Jewish leadership to switch as quickly as the majority of the Israeli electorate could on how to best implement the State of Israel's national priority of best defending its borders both in the short-term and long-term. That's not to say that American Jewry enthusiastically lined up to support the governments of Begin and Shamir, particularly their oft-stated desire to bolster and increase Jewish West Bank/Gaza Strip settlements. In fact, privately some American Jewish leaders, such as Conference of Presidents chair Shoshana S. Cardin asked Shamir to cool the confrontational policies with the Bush administration. Yet publicly the general approach of supporting the decisions of the democratically elected government of Israel remained the community mantra.

Ironically, while Shamir rarely publicly criticized U.S. Jews, the gruff Rabin had no such inhibitions. On his first trip to Washington after being reelected Prime Minister, 
he lashed out at AIPAC for its loyal defense of Shamir's insistence that Israel should be granted by the United States $\$ 10$ billion in loan guarantees regardless of the White House's strong opposition to its settlement policies. For his part, Rabin could point to the success of his methods; the Bush administration granted his government the loan guarantees (minus $\$ 400$ million that it deducted for West Bank/Gaza settlement building during Shamir's tenure).

In fact, dissension with American Jewry was a theme of Rabin's 1992-95 prime ministership. To be sure, he would apologize for various outbursts, seemingly with an internal understanding that ultimately American Jewry was a critical partner in Washington. Still, only weeks before his murder - a time in which the Oslo process was in full force as the second Oslo agreement had just been signed - Rabin was again publicly and harshly condemning American Jewish leaders who opposed his policies.

Meanwhile, some of Rabin's top lieutenants went far beyond aiming their criticism only at foreign policy issues. Rather, they sought to undermine what they perceived as the outdated and damaging paternalistic attitude of American Jews regarding Israel. Yossi Beilin, Avram Burg and Avraham Shochat and others would belittle the importance of American Jewry's focus on fundraising for the social service needs of Israelis, even declaring that it was time for international Zionist organizations to go out of business as their mission of creating an independent Jewish state had been accomplished. Beilin, in particular, continued to emphasize the joint destiny of the Jewish people while calling for new, more democratic and creative structures to replace the outdated ones in place since the decades before the State of Israel's founding. For his part, Israeli President Ezer Weizman, while not appointed by Rabin, exacerbated tensions in a 1994 
Jewish identity conference with Diaspora leaders at his official residence in Jerusalem. There, he reinforced the traditional Zionist notion of "negating the Diaspora" by lambasting the concept of healthy Jewish life outside of Israel. He even forcefully told his guests that there was no viable Jewish future outside of the State of Israel.

Regardless, Rabin's policies put the Government of Israel back in good standing with the first Bush administration and then with the new Clinton White House, which enabled organized American Jewry to breathe a little more easily. In fact, Rabin and Clinton were to form an unusually close bond, one that many likened to a father-son relationship. When Rabin was assassinated, Clinton emotionally uttered the Hebrew words "Shalom chaver" - goodbye friend, which profoundly touched both Israeli and American Jewry. The expression spoke deeply of the bond Clinton had for Israel and the Jewish people, a tie that would be tested during the coming Netanyahu years. It also in part explained the extraordinary leeway the American leader would give Barak -anointed by public opinion as a leader in Rabin's mold - the chance to shape the style and content of what many believed would be the final and successful effort to craft an "end of conflict" agreement between Israel and the Palestinians, and by extension the Arab world.

Barak also specifically told American Jews that the days of charitable giving to Israel were over. Rather, he said, they should view their relationship toward Jerusalem in crass investment terms: They could invest in the Jewish state and make money there, which would do more to build the country than any charitable donation ever could. After all, it would produce jobs and fuel a healthy economy. While not abandoning their efforts to raise funds for Israel's social service needs, American Jewish communities indeed warmed to the idea of emerging economic ties. Numerous Jewish federations went about 
promoting various state trade commissions and offices designed to promote business ties between business in their states and Israel. Often, leading Jewish businessmen were involved in these efforts. In addition, the Partnership 2000 effort included funding job incubator programs in Israel.

Meanwhile, the increasingly divided response of American Jewry to the Oslo Accords revealed and even accentuated an existing Jewish-Jewish divide in the United States, one often framed in the response of the religious streams. The most obvious schism was between followers of the Orthodox Union and the Union of American Hebrew Congregations, which was Reform Jewry's national congregational arm. The former was nervous about potential and then actual Israeli concessions while the latter gave such moves its enthusiastic support. (The Conservative movement, which according to the National Jewish Population Survey (NJPS) had from 1990 until 2001 lost its standing as the largest Jewish denomination, did not have a Washington presence; thus, despite various pronouncements its religious leaders were not seen as a major factor in the American Jewish debate on the Oslo process.)

Meanwhile, despite primarily secular groups such as the Zionist Organization of American (ZOA) and Americans for a Safe Israel (AFSI) being increasingly vocal in their opposition to Oslo's process, most major organizations - including the so-called "defense agencies" such as the Anti-Defamation League, the American Jewish Committee and the American Jewish Congress, as well as the consensus seeking National Jewish Community Relations Advisory Council (later the Jewish Council for Public Affairs) - were willing to support the Rabin government's peacemaking moves. 


\section{VI.9 A Move Inward}

At the same time, while American Jewry's national agenda was adjusting to the success of its pushes for the Holocaust memorialization and the Soviet Jewry movement, an increasingly important issue for many was advancing the "continuity agenda." The first major signpost of it, one that would give more emphasis to cultivating Jewish identity at home, came with the 1991 release of the 1990 National Jewish Population Study (NJPS) of the Council of Jewish Federations. Its most glaring reported statistic was that 52 percent of new marriages by Jews were to non-Jews. Combined with other studies showing a dramatic decrease in the affiliation rate of the children of such unions, American Jewry mobilized the continuity agenda, which eventually was referred to by some as a "Jewish renaissance."

In doing so, at least at the moment, much of organized American Jewry's apparatus showed an ability to continue rallying around a new central theme. This was seen in the building or expansion of non-Orthodox day schools, more money for Jewish summer camps, and the rise of the spirituality movement as seen in the Jewish Renewal Movement (and the writings of authors such as Arthur Waskow, Zalman Zachter-Shalmi, and Rodger Kamenetz, among others). There also was an infusion of Jewish texts and use of Hebrew, such as the implementation of volunteer created divrei Torah at the start of board meetings of secular social service agencies, Jewish text study at gatherings such as the various federation movement General Assembly meetings, the use of words such as "Shoah" instead of the English "Holocaust," and more.

In part, making room for this shift from worrying about Israel's existential wellbeing toward Jewish identity building were the responses of Israeli leaders themselves. 
Some of them were saying that the historical concern for Israel's survival was at an end. That was because, they said, while the road to peace would be difficult, the path was irreversible. Indeed, even in the Netanyahu years there was no serious talk about ending the increasingly shaky Oslo Accords. Rather, the fight was over implementation and its signposts. After all, Netanyahu eventually gave up Israeli control 80 percent of Hebron (home to the believed burial cave of Judaism's patriarchs and matriarchs). Then at Wye, Netanyahu agreed to further West Bank withdrawals.

Unfortunately, this enabled a further turning inward for American Jews at a moment when the Israeli political climate became increasingly difficult to understand. Long gone were the mythic figures such as David Ben-Gurion, Moshe Dayan and Golda Meir. Instead, newcomers to the study of Israeli politics were left to try and figure out Israel's raucous and increasingly fractured political system, one that reflected the nation's social divides. Indeed, the Knesset itself was now experiencing unprecedented political divides that included conflicts such as Sephardi vs. Ashkenazi religious Jews, religious vs. secular Jews, settlers vs. land for peace advocates, Russians vs. veteran Israelis, and Jews vs. Arabs. Meanwhile, changes in election laws that allowed for one to vote for both a party and prime minister's candidate enabled small parties to have increased political clout.

Clearly, the once easily digestible "Likud vs. Labor" divide was long gone. This all would continue to make Israel a harder place to relate to for American Jews, particularly younger ones without an emotional attachment to the history of Israel's precarious birth in 1948 and then its full scale wars of 1967 and 1973. 


\section{VI.10 New Efforts At American Jewish-Israeli Ties}

At the same time, Israel's well-being was far from absent from the American Jewish agenda. In fact, substantial efforts were made to shift the relationship of American Jews with Israel from one of an Israel in crisis to the development of more personal ties between Jews on both sides of the Atlantic Ocean. As such, person-to-person ties were formed such as Partnership 2000, which focused on joint American/Israel committees deciding on their communities' mutual needs. As similar effort was the Taglit-Birthright Israel effort. One of its more unique features was the equal funding partnership between "mega-philanthropists" such as Charles Bronfman and Michael Steinhardt, the Government of Israel, and the North American Jewish federation system. Indeed, Israel's giving back to the Diaspora, as Netanyahu put it, marked a new turn in ties between the two communities.

On the one hand, some communal planners were encouraged by the rise in percentages of American Jews having traveled to Israel. In fact, that number according to the 2000-2001 NJPS rose to 41 percent from what had been the mid-20s in 1990. But on the other hand, it was sobering to realize that in the time period between those two major population studies, the overall number of American Jews had dropped from 5.8 million to 5.2 million. In other words, on a percentage basis there might have been more American Jews heading to Israel than ever (and there certainly was more money funding such efforts), but overall there were simply fewer Jews than before. In part, this reflected a community in which those on the periphery were leaving more quickly than the growing core could compensate. So while Jewish day schools, particularly non-Orthodox ones, were a sign of openness toward growing commitment by many Jewish families, more 
people were opting out of organized Jewish life than those who were showing deepened allegiance to it. This was particularly true when it came to the children of intermarried Jews, the vast majority of whom were not choosing to live their adult lives as participants in the Jewish community.

In addition, Steven M. Cohen's surveys continued to show generational slides in passion for Israel. That was understandable as older American Jews - ones who personally experienced both the Holocaust and the early triumphs and tragedies of the Jewish state - felt a more powerful inherent bond to the State of Israel and the Jewish people due to their personal understanding that both could be faced with serious existential threats. In fact, in 1995 the pro-Israel agenda of a 25-year-old American Jew would likely have been formed by watching the first intifada and then Israeli peace making efforts while that of a 55-year-old counterpart was likely to have been shaped by responding to the 1967 and 1973 wars.

\section{VI.11 Response To Rabin Assassination}

The November 4, 1995 Rabin assassination was deeply traumatic for the Jewish people in Israel, the United States, and elsewhere. Ironically, its aftermath briefly provided what Rabin had not been able to accomplish in the tumultuous last two years of his life - an inward searching and sense of unity amongst much of the Jewish population. However, such calls for Jewish unity were literally battered within one month. Only 30 days after the murder, a high profile memorial event in Madison Square Garden was lambasted by Oslo opponents as an inappropriate peace rally. Some groups, particularly Orthodox ones, threatened a boycott of the event. This stemmed from the mistake of the 
American Jewish organizers in not allowing opposition Likud leaders to address the crowd, the excuse being that Shimon Peres was Israel's Prime Minister and he would speak for the Government of Israel.

The Rabin assassination, however, did bring at least renewed attempts to calm frayed nerves and increase Jewish civility in the heated communal debates brought about both by the peace process and the long standing strains regarding religious pluralism. As such, upon becoming prime minister, Peres appointed Rabbi Yehuda Amital to nurture a dialogue with both Israeli settlers and the primarily Orthodox American Jewish opponents of the Oslo process. Amital, a respected Haredi rabbi and founder of the prominent West Bank yeshiva (the Har Etzion Yeshiva in Alon Shvoot), was given ministerial status in the Peres government. He soon set off to New York City to meet with leading Orthodox rabbis here, a continuation of similar efforts in Israel. Having a high profile government representative take up the unity mantle was also important to the Netanyahu administration, which appointed the highly respected Yaacov Ne'eman (who was modern Orthodox) and Natan Sharansky (who was traditional in his lifestyle) to direct the effort. Barak continued this new tradition, appointing Rabbi Michael Melchior, his fellow One Israel (the newest name for the Labor Party-led coalition of parties) minister, to the post.

For its part, after Rabin's murder the Clinton administration sought to assure all Americans and Israelis that its commitment to the peace process was unshakeable. In doing so, it all but openly endorsed Peres's unsuccessful May 29, 1996 election bid, a policy it would repeat (successfully this time) with Barak's late May 1999 victory. While the White House's hopes were achieved in one election but not the other, the domestic 
American Jewish and Israeli Jewish interest in the U.S. administration's efforts gave evidence to the weight that communities in both countries placed in strong U.S.-Israeli ties.

\section{VI.12 Netanyahu's Tenure}

Netanyahu came into office but eight months after Rabin's death, an event that still very much tainted the Israeli political scene. In addition to his differences with Peres when it came to the U.S.-backed peace process, Netanyahu arrived to power with a great handicap regarding the traditional use of American Jewry as a conduit to the White House. That was because American Jews had overwhelmingly voted for Clinton in his 1996 reelection bid. But much of Netanyahu's U.S. support came from both the GOP and its conservative Christian base. So in addition to ongoing policy strains with the Clinton administration, Netanyahu's alliance with increasingly partisan Republicans - also a bulwark of hard-line pro-Israel policies - angered the Democratic White House and some of its American Jewish backers.

In fact, Netanyahu at times directly turned to U.S. Christians for support before important Clinton administration meetings, such as the 1998 Wye River negotiations. This aroused great concern for many American Jews not just because of policy differences, but due to the Christians' historic emphasis on evangelism, which included support for Hebrew Christian messianic groups such as Jews for Jesus. There was increasingly little that Jews agreed upon, but minimizing the influence of such missionary groups was on the short list. 
Still, as a keen observer of American political life, Netanyahu knew that in the Republican-controlled Congress, he would have political allies as he sought to blunt the Clinton administration's strong support for the Rabin/Peres land-for-peace policies; he and his supporters in Israel and among many U.S. Orthodox Jews found such concessions anathema to their historical belief in Greater Israel, which incorporated unfettered Jewish settlement in the West Bank biblical heartland, which they referred to by the biblical names of Judea and Samaria.

\section{VI.13 Lessons From The Conversion Crisis}

As the Oslo process continued to stoke the divisions of American Jewish life regarding pro-Israel advocacy, Netanyahu's government in particular accentuated the turmoil in the Israeli-Diaspora relationship with its approach to the "Who Is A Jew" issue. In short, Israeli law was purposely vague regarding who constituted a Jew. It also did not specify whether any rabbi or only Orthodox rabbis could perform a conversion. The de facto understanding since the state's beginning was that in Israel only the life cycle ceremonies of the state-approved Orthodox rabbinate were valid. Yet, those performed outside of the Jewish state by any rabbi would be valid within Israel were the participants in such ceremonies to make aliyah. In other words, if a woman converted by a non-Orthodox rabbi in the United States moved to Israel, both she and her children were to be considered Jewish by the Government of Israel, which entailed certain legal and societal benefits. That, however, violated an Orthodox understanding of Halachah (Jewish law). So bringing the law in line with Orthodox sentiments was a periodic 
demand of Orthodox religious parties as they were wooed by various Labor- and Likudled coalitions.

While far from a new issue - the debate had been part of the country's political scene since the state's founding - it exploded with rancor after the 1996 elections brought Netanyahu and his Orthodox coalition partners (particularly Shas) to power. In fact, by 1997 the "conversion crisis" had become the lead item on the Diaspora-Israel agenda and was the main story of that year's General Assembly. There, Netanyahu asked for U.S. Jews to support the ongoing efforts of his conversion compromise committee. That effort, headed by Ne'eman, would go on to create a conversion court system. As part of the process, the conversion candidate would study with the rabbi of his or her choicemeaning potentially non-Orthodox ones. Yet, he or she would given a final test by and then formally converted by an Israeli Orthodox rabbi. American Jewish Reform and Conservative leaders agreed to the compromise as did their Israeli counterparts. As a result, lawsuits were temporarily shelved, as was potential legislation in the Knesset.

Pressing Netanyahu to make progress in this area was not only the anger of Diaspora Jews, but also the reality that up to one-third of the former Russian immigrants were not considered Jewish according to Jewish law. This, too, offered an important lesson for American Jews who wanted to help shape the Government of Israel's relationship to modern Judaism: Just as the Jackson-Vanik Amendment promoted broader American values, when American Jews could have their concerns relate to broader Israeli ones, they could have more success. Indeed, were Netanyahu not facing pressure to deal with the Jewishness of Russian immigrants (a majority having voted for him on the prime 
ministerial ballot) it is unlikely that he would have been as susceptible to pressure on the conversions issue.

The whole episode showed that American Jewry can play a role in shaping Israel's Jewishness under certain conditions. After all, Netanyahu was not out to please the small and politically unimportant Israeli Conservative and Reform Jews. Rather, as leader of the Jewish state, he seemed bound to both help Russians in Israel - a coalition partner being Sharansky’s Russian-immigrant based Yisrael B’aliyah party - and exhibited a loyalty to the concept of Jewish peoplehood (as seen in his major address remarks at the $1997 \mathrm{GA})$. Likewise, the episode reveals that Israeli leaders do not want to unduly alienate American Jews, whose lobbying influence they needed in Washington.

During Barak's tenure, there was much less focus on the "Who is a Jew?" issue. In large part Barak, a secular product of both the Israeli kibbutz and army sectors, did not seem interested in the topic. Nor did he feel bound to move forward by pressure from his Orthodox coalition partners. That's because he had a very large coalition whose right and left wings could be balanced against one another. In fact, Barak was planning to move so quickly and dramatically on the peace process that within less than one year in office he was preparing for major concessions. There was little talk of little else. In fact, it was over the peace process - not religious pluralism ones - that Barak lost his religious coalition partners.

\section{VI.14 Camp David II Talks And Renewed Violence}

Perhaps the most lasting impact of Barak's time in office was that detailed plans for an Israeli-Palestinian peace agreement were explored during the July 2000 Camp 
David II Summit and afterward - continuing even in the face of violence from late September 2000 to January 2001. For the first time, comprehensive, detailed compromises to the intractable core problems of the conflict - settlements, borders, refugees, governance of Jerusalem (including Har HaBayit/Haram al-Sharif) - were on the table.

Yet, despite two weeks of virtually around the clock U.S.-led efforts, the Israelis and Palestinians would go home without agreement (despite the mutual pledge to continue negotiating). Clinton broke a promise not to blame Arafat for the failure, doing so to help Barak with his tattered domestic political situation in which he now controlled a minority coalition government. This, too, showed the depth of the U.S.-Israeli relationship. Despite his frustrations with Barak during the Camp David talks, as shown in the published biographies of American negotiators, Clinton only had public words of praise for his Israeli counterpart. It is difficult to imagine that had Barak been seen as more intransigent than Arafat, that the U.S. president would have openly blamed the Israeli for the lack of success.

The beginning of the end of the Oslo process, which began with the outbreak of the Al-Aksa Intifada in late September 2000, saw American Jewish leadership return to the "crisis mode" of defending an embattled Jewish state. In fact, American Jewish leadership responded quickly and strongly - as if happy to again have a more focused, unifying role when it came to Israel's well-being. Yet, this also occurred as a younger generation of American Jews had become distanced from Israel. This was in part because they were searching for a sense of belonging for which "spirituality" offered a response. Meanwhile, some felt that cultivating such a sentiment was not offered by traditional 
religious/communal affiliations, a framework whose groups formed the bulwark of the pro-Israel community. It also was in part because Israeli leaders themselves had given their American Jewish counterparts informal permission to focus on domestic needs, saying in recent years that with Israel on the road to peace the paramount need was strengthening American Jewish identity at home.

For some, of course, the crisis for Israel's well-being had never abated. Indeed, the small but vocal American opponents of the Oslo process, such as the Zionist Organization of America and much of the Orthodox community, saw the results of Oslo as inevitable. For them, not only was Israel always under an existential threat, but by September 2000 it was in a much worse position than in early 1993. After all, now Arafat's minions were armed and had gained impressive funding and sympathy from the world community, not to mention a foothold on what they saw as their territory.

Nonetheless, much of organized American Jewry continued to openly hope for not only a cessation of violence, but a return to negotiations. Certainly Barak wanted that as he continued to negotiate with the Palestinian Authority and Yasser Arafat despite the new Palestinian uprising and Israeli counter-attacks. In fact, almost until the last possible moment Barak and Arafat's lead negotiators gave peace process advocates hope as they continued to try and hammer out a final status deal.

That came in two stages, first with Washington taking the lead and then without a White House both exhausted and exasperated by the effort. First came Clinton's final status parameters of late December 2000, discussions over which stretched into January only several weeks before the end of the U.S. administration's tenure. The Israelis accepted the framework based on the condition that the Palestinians would do so as well. 
Yet, Arafat would not give a conclusive answer, effectively ending the Clinton administration's role in brokering a major Mideast peace accord.

There was one more attempt at top-level Israeli-Palestinian negotiations. This was the talks at Taba, Egypt, but they were not conducted with U.S. oversight. Nonetheless, Barak had hoped their successful outcome would lead to his reelection in Israel's February 6, 2001 election. Barak in fact had called for those early elections to spur on the negotiations, which would hopefully result in an agreement. Thus, the Israeli elections ballot would ostensibly be presented as a public referendum of a final status deal, not to mention cement another term for the Israeli leader.

Throughout this period, American Jews continued to become increasingly disenchanted with Barak, who had earlier been seen as the inheritor of Yitzhak Rabin's vaunted mantle of warrior turned peace maker. Yet they continued to support President Clinton's efforts. When the Israelis accepted but the Palestinians rejected the U.S. leader's final status proposals, American Jewish leaders were more confident than ever that Arafat, not the Jewish state, was responsible for the demise of the peace talks.

One result for American Jews, mirroring that of the Israeli electorate, was increasing support for now Likud leader Ariel Sharon, who was challenging Barak in the February 2001 Israeli elections. A few years earlier, such recognition would have been unthinkable. Sharon had long been a lightning rod of anti-Israel criticism, linked to the 1982 Sabra and Shatilla massacres during the Lebanon War and other controversial events in the State of Israel's history.

\section{VI.15 Final Thoughts}


The seemingly relentless involvement of the Clinton administration in ArabIsraeli peacemaking efforts showed the great lengths to which the White House would support serious efforts toward an Arab-Israeli peace, particularly when such initiatives were openly backed by an Israeli prime minister. Even during the Netanyahu years, the Clinton administration refused to walk away from this increasingly difficult area of foreign policy. This also showed how a sense of personal attachment by a U.S. president can keep the process alive. Indeed, this was a world apart from the disparaging comments of Secretary of State James Baker III to the U.S. Congress that when Israel was ready for serious negotiations, its leaders could call the White House switchboard to inform the president. In Clinton, here was a U.S. president who on his own came up with final status parameters meant to give yet another last, best chance to peace - not to mention his own legacy as an historic peacemaker.

When it came to American Jews, and particularly communal leadership, it seemed that nothing could deter them from working for both a political pro-Israel agenda and furthering a sense of personal attachment to the fate of the Jewish state - despite the fraying extremes of American Jewish opinion. Indeed, major new initiatives such as Taglit-Birthright Israel were undertaken to meet the emerging needs of younger American Jews. Examples were shifting from a philanthropic-based relationship to one of financial partnerships, joint-community building efforts, and nurturing professional relationships among equals.

Nonetheless, internal shifts in American Jewish life throughout the Oslo years led to increasing concerns regarding the long-term outlook for American Jews, particularly in numerical terms. If such trends continued, they could impact American Jewish political 
standing, which could damage the community's ability to advance its pro-Israel agenda. At the same time, by the end of the Oslo years in America Jews were politically, socially and financially more secure than at any point since their arrival on the continent.

These contradicting realities left the community with great question marks when it came to where to place its emphasis on next steps regarding strengthening American Jewish identity and the effort to understand and relate to an increasingly complex State of Israel. The Oslo process was at an end, but the quest to forge communal consensus that could result in effective policy making and results had taken new turns. 


\section{Selected Bibliography and Sources}

\section{$\underline{\text { Books }}$}

Albright, Madeline. Madame Secretary: A Memoir. New York: Miramax, 2005.

Ateek, Naim and Rosemary Radford Ruether, Justice and Only Justice: A Palestinian Theology Of Liberation. Maryknoll, N.Y.: Orbis Books, 1989.

Aumann, Moshe. Conflict \& Connection: The Jewish-Christian-Israel Triangle. New York: Geffen, 22003.

Baker III, James A. The Politics of Diplomacy: Revolution, War and Peace 1989-1992. New York: G. P. Putnam's Sons, 1995.

Bar-Zohar, Michael. Shimon Peres: The Biography. New York: Random House.

Beilin, Yossi. His Brother's Keeper: Israel and Diaspora Jewry in the Twenty-first Century. New York: Schocken, 2000.

Brog, David. Standing With Israel: Why Christians Support the Jewish State. Charleston, S.C.: Frontline, 2006.

Michael Berenbaum, After Tragedy and Triumph: Modern Jewish Thought and the 3American Experience. Cambridge: Cambridge University Press, 1990.

Bar-Zohar, Michael. Shimon Peres: The Biography. New York: Random House, 2007.

Cardin, Nina Beth. The Tapestry of Jewish Time: A Spiritual Guide to Holidays and LifeCycle Events. New York: Behrman House Publishing, 2000.

Christopher, Warren. Chances Of A Lifetime: A Memoir. New York: Scribner, 2001.

Clinton, William Jefferson. My Life. New York: Knopf, 2004.

Cohen, Steven M. and Arnold M Eisen. The Jew Within: Self, Family, and Community in America. Bloomington, In.: Indiana University Press, 2000.

Dershowitz, Alan. The Vanishing American Jew: In Search of Jewish Identity for the Next Century. Boston: Little, Brown And Company, 1997.

Diamant, Anita. The Red Tent. New York: Picador USA, 1997.

---. The New Jewish Wedding. New York: Scribner, 2001. 
Elazar, Daniel J. and Rela Mintz Geffen. The Conservative Movement in Judaism: Dilemmas and Opportunities. Albany, N.Y.: State University of New York Press, 2000.

Freedman, Robert O. Soviet Jewry in the 1980s: The Politics of Anti-Semitism and Emigration and the Dynamics of Resettlement. ed. Robert O. Freedman. Durham, N.C.: Duke University Press, 1989.

Gal, Allon. Envisioning Israel: The Changing Ideals and Images of North American Jews. Wayne State University Press: Detroit, 1996.

Goldberg, J.J. Jewish Power: Inside the American Jewish Establishment. Reading, MA: Addison-Wesley Publishing Co., 1996.

Granchow, Mendy. Journey Through The Minefields: From Vietnam to Washington: An Unorthodox Surgeon's Journey. Silver Spring, Md.: Eshel Books, 2004.

Grose, Peter. Israel In the Mind Of America. New York: Knopf, 1983.

Gershom Gorenberg. The End Of Days: Fundamentalism and the Struggle for the Temple Mount. Oxford, England: Oxford University Press, 2000.

Hertzberg, Arthur. A Jew In America. New York: Harper Collins, 2002.

---. The Fate of Zionism: A Secular Future for Israel \& Palestine. New York: Harper Collins Publishers, Inc., 2003.

Heschel, Abraham Joshua. Israel: An Echo of Eternity. New York: Farrar, Straus And Giroux, 1969.

Hazony, Yoram. The Jewish State: The Struggle for Israel's Soul. New York: Basic/New Republic Books, 2000.

Indyk, Martin. Innocents Abroad: An Intimate History of American Peace Diplomacy in the Middle East. New York: Simon \& Schuster, 2009.

Kamentz, Rodger. The Jew in the Lotus. San Francisco: HarperOne, 1994.

---.Stalking Elijah: Adventures With Today's Mystical Jewish Masters. HarperOne: New York, 1997.

Koch, Edward I. and Rafael Medoff. The Koch Papers: My Fight Against Anti-Semitism. New York: Palgrave Macmillan, 2008. 
Kissinger, Henry. Years Of Upheaval. Boston: Little, Brown and Company, 1982.

Kolsky, Thomas. Jews Against Zionism: The American Council for Judaism (1942-1948). Philadelphia: Temple University Press, 1990.

Laqueur, Walter and Barry Rubin. eds. The Israel-Arab Reader: A Documentary History of the Middle East Conflict. New York: Penguin Books, 2008.

Leibler, Isi. The Israel-diaspora identity crisis: A looming disaster. New York: World Jewish Congress, 1994.

Lerner, Michael Lerner, Spirit Matters. Charlottesville, Va.: Hampton Roads Publishing, 2002.

Ian Lustick, Jewish Fundamentalism In Israel: For the Land and the Lord. New York: Council on Foreign Relations, 1988.

Lapin, Daniel. Buried Treasure: Hidden Wisdom From The Hebrew Language. Waterbrook Multnomah Publishing Group: Colorado Springs, Col., 2001.

Maisel, Sandy L. and Ira N. Forman. Jews In American Politics. New York: Rowman \& Littlefield Publishers, Inc., 2001.

Miller, Aaron David. The Much Too Promised Land: America's Elusive Search For Arab-Israeli Peace. New York: Bantam Dell, 2008.

Oren, Michael B. Six Days of War: June 1967 and the Making of the Modern Middle East. Oxford, England: Oxford University Press, 2002.

Putnam, Robert D. Bowling: Alone: The Collapse and Revival of the American Community. New York: Simon \& Schuster, 2000.

Quandt, William. Peace Process: American Diplomacy and the Arab-Israeli Conflict Since 1967. $3^{\text {rd }}$ ed. Washington, D.C., and Berkeley, CA: Brookings Institution Press and University of California Press, 2005.

Rabin, Yitzhak. The Rabin Memoirs: Expanded Edition With Recent Speeches, New Photographs and an Afterward. University of California Press: Berkeley, CA., 1996.

Raphael, Marc Lee. Profiles in American Judaism: The Reform, Conservative, Orthodox, and Reconstructionist Traditions in Historical Perspective. San Francisco: Harper \& Row Publishers, Inc., 1984.

Ravitzky, Aviezer. Messianism, Zionism, and Jewish Religious Radicalism. Chicago: The University of Chicago Press, 1993. 
Rosenthal, Steven T. Irreconcilable Differences: The Waning of the American Jewish Love Affair With Israel. University Press of New England for Brandeis University Press: Hanover, N.H. 2001.

Ross, Dennis. The Missing Peace: The Inside Story of the Fight For Middle East Peace. New York: Farrar, Straus and Giroux, 2004.

Rubin, Barry and Judith Colp Rubin. Yasir Arafat: A Political Biography. Oxford, England: Oxford University Press, 2003.

Sachar, Howard M. A History of Israel: From the Rise of Zionism to Our Time. $3^{\text {rd }}$ ed. New York: Knopf, 2007.

Sanua, Marianne R., Let Us Prove Strong: The American Jewish Committee 1945-2006. Waltham, Mass.: Brandeis University Press, 2007.

Segev, Tom. 1967: Israel, the War, and the Year that Transformed the Middle East. trans. Jessica Cohen. New York: Metropolitan Books, 2005.

Shamir, Yitzhak. Summing Up: An Autobiography. Diane Publishing Co.: Darby, Pa., 1994.

Wertheimer, Jack. ed. Jews in the Center: Conservative Synagogues and their Members. New Brunswick, N.J., and London: Rutgers University Press, 2000.

Woocher, Jonathan. Sacred Survival: The Civil Religion of American Jews. Bloomington, Ind.: Indiana University Press, 1986.

\section{Chapters In Books}

Bick, Etta. "Sectarian Party Politics in Israel: The Case of Yisrael Ba'Aliya, the Russian Immigrant Party," in Daniel J. Elazar and Shmuel Sandler, eds., Israel At the Polls 1996 London: Frank Cass, 1998. 121-145.

Burg, Avraham. "Brit Am: A Covenant of the People, Proposed Policy Guidelines for the National Institutions of the Jewish People," in Richard Juran and Debbie Sapir, eds., Diversity of Voices: Contemporary Jewish Issues in Their Israeli Context. eds. New York: JCC Association of North America, 1998. 64-67.

Cohen, Steven M., "Did American Jews Really Grow More Distance from Israel, 1983 -1993? - A Reconsideration," in Allon Gal, ed., Envisioning Israel: The Changing Ideals and Images of North American Jews. Wayne State University Press: Detroit, 1996. 352-373. 
Eisen, Arnie. "Israel At 50: An American Jewish Perspective." American Jewish Yearbook 1998. New York and Philadelphia: The American Jewish Committee and The Jewish Publication Society, 1998. 47-74.

Feurberger, Marvin. "Israeli-American Relations in the Second Rabin Era," in Robert O. Freedman, ed., Israel Under Rabin. Boulder, Col.: Westview Press, 1995. 9-21.

Eisen, Arnold M. "Israel At 50: An American Jewish Perspective." American Jewish Yearbook 1998. New York and Philadelphia: The American Jewish Committee and The Jewish Publication Society, 1998. 47-71.

Foltin, Richard. "National Affairs." American Jewish Yearbook 2000. New York and Philadelphia: The American Jewish Committee and The Jewish Publication Society, 2000. 149-188.

---. "National Affairs.” American Jewish Yearbook 2002. New York and Philadelphia: The American Jewish Committee and The Jewish Publication Society, 2001. 145-194.

Freedman, Robert O. "Soviet Jewry as a Factor in Soviet-Israeli Relations," in Soviet Jewry in the 1980s and the Dynamics of Resettlement. Durham, N.C.: Duke University Press, 1989.

Goldstein, Sidney. "Profile of American Jewry: Insights From The 1990 National Jewish Population Survey." American Jewish Year Book 1992. New York: American Jewish Committee, 1993. 7-173.

Grossman, Lawrence “American Jewish Communal Affairs.” American Jewish Yearbook 1994. New York and Philadelphia: The American Jewish Committee and The Jewish Publication Society, 1994. 184-205.

---. “American Jewish Communal Affairs.” American Jewish Yearbook 1995. New York and Philadelphia: The American Jewish Committee and The Jewish Publication Society, 1995. 151-180.

---. “American Jewish Communal Affairs.” American Jewish Yearbook 1997. New York and Philadelphia: The American Jewish Committee and The Jewish Publication Society, 1997. 176-214.

---. “American Jewish Communal Affairs.” American Jewish Yearbook 1998. New York and Philadelphia: The American Jewish Committee and The Jewish Publication Society, 1998. 109-149.

---. “American Jewish Communal Affairs.” American Jewish Yearbook 2000. New York and Philadelphia: The American Jewish Committee and The Jewish Publication 
Society, 2000. 208-241.

---. “American Jewish Communal Affairs.” American Jewish Yearbook 2001. New York and Philadelphia: The American Jewish Committee and The Jewish Publication Society, 2001. 221-246.

---. "American Jewish Communal Affairs." American Jewish Yearbook 2002. New York and Philadelphia: The American Jewish Committee and The Jewish Publication Society, 2002. 221-246.

Gruen, George E. "The United States, Israel and the Middle East.” American Jewish Yearbook 2000. New York and Philadelphia: The American Jewish Committee and The Jewish Publication Society, 2000. 189-207.

Jacobson, Kenneth. "The United States, Israel and the Middle East." American Jewish Yearbook 1994. New York and Philadelphia: The American Jewish Committee and The Jewish Publication Society, 1994. 153-183.

Inbar, Efraim. "Labor's Return To Power," in Daniel J. Elaza and Shmuel Sandler, eds., Israel At The Polls, 1992. New York: Rowman \& Littlefield Publishers, Inc., 1995. 2743.

Raffel, Martin J. "History of Israel Advocacy," in A. Mittleman, J. Sarna and R. Lichts, eds., Jewish Polity and American Civil Society:Communal Agencies and Religious Movements in the American Public Square. New York: Rowman and Littlefield, 2002. 103-179

Rubin, Barry. "External Influences on the Israeli Elections," in Daniel J. Elazar and Shmuel Sandler, eds., Israel At The Polls 1996. London: Frank Cass, 1998. 149-166.

Waxman, Chaim I., "Center and Periphery: Israel in American Jewish Life," in Roberta Rosenberg Farber and Chaim I. Waxman, eds., Jews in America: A Contemporary Reader. Hanover, Conn.: University Press of New England, 1999. 212-225.

Wertheimer, Jack, "Breaking the Taboo: Critics of Israel and the American Jewish Establishment," in Allon Gal, ed., Envisioning Israel. Jerusalem: Magnes Press; Detroit: Wayne State University Press, 1996. 397-408.

---. "Current Trends in American Jewish Philanthropy," in American Jewish Year Book 1997. New York: American Jewish Committee, 1997. 3-92.

\section{Journal Articles and Monographs}


Bayme, Steven. "Israel and American Jewry: Oslo and Beyond." Institute for Global Jewish Affairs. 15 Jan. 2008. Web. 22 February 2009.

Ben-Moshe, Danny. "The Impact of the Al-Aqsa Intifada On Israeli-Diaspora Relations." Israel Studies Forum 19.3 (2004): 28-57.

Bleich, J. David. "Withdrawal From Liberated Territories as a Viable Halachic Option." The Journal of Halacha and Contemporary Society 18.3 (1989): 101-110.

"Camp David II: The Aftermath.” Anti-Defamation League, 27 July 2000. Web. 12 July 2009.

Hadar, Leon. "The Real Lesson of the Oslo Accord: 'Localize' the Arab-Israeli Conflict." The CATO Institute, Washington, D.C. 9 May 1994. Web. 15 July 2009. Address.

Halkin, Hillel. "The Jewish State and the Jewish Peoples." Commentary. 105:5 (1998): 50-55.

Hirsch, Amiel et.al. “A Symposium: Reform Judaism and Zionism.” CCAR Journal Spring 1998. 26.3 (1998): 1-54.

Jerusalem In Danger. (New York: Zionist Organization of America, 2000).

Korn, Eugene. Meeting The Challenge: Church Attitudes Toward the Israeli-Palestinian Conflict. (New York: Anti-Defamation League, 2002).

Librach, Clifford E. "Does Conservative Judaism Have a Future?" Commentary. 106.3 (1998): 28-33.

Lerner, Michael, et.al. “Israel At 50.” Tikkun. 13.2 (1998): 33-80.

Liebler, Isi. "The Israel-Diaspora Identity Crisis: A Looming Disaster.” (New York: World Jewish Congress, 1994).

---. “Another Statement on the Peace Process. Commentary. 95.6 (1993): 25-30.

---. “The Peace Process So Far.” Commentary. 96.2 (1994): 21-25.

Pipes, Daniel. “Bush, Clinton, and the Jews.” Commentary. 94.10 (1992): 15-19.

Raffel, Martin J. “American Jewish Public Affairs and Israel: Looking Back, Looking Ahead." The Reconstructionist Spring. 62.2 (1998): 55-65.

---. "History of Israel Advocacy." in Alan Mittleman, Jonathan D Sarna and Robert Licht, eds., Jewish Polity and American Civil Society: Communal Agencies and Religious 
Movements in the American Public Sphere (Lanham, Md. And Oxford, England: Rowman \& Littlefield, 2002).

Raphael, Marc Lee. "The Emergence and Development of Tradition in Reform Jewish Worship.” Jewish History. 15.2 (2001): 119-130.

Rubin, Barry. "The U.S. In The Middle East, 1998." Middle East Review of International Affairs. 1998. Web. 23 June 2009.

Shneyer, Beata. "Anti-Semitism and Pro-Israeli Campus Activism: A Case Study: University of California, Berkeley." Jerusalem Center For Public Affairs Institute for Global Jewish Affairs. Web. 5 Aug. 2009.

Steinberg, Gerald M. "Interpretations Of Jewish Tradition On Democracy, Land, And Peace.”Jerusalem Viewpoints. 439.2 (2000). Web. 14 May 2008.

Streicker, Joel. "Restoring the Prominent Middle.” Judaism. 50.200 (2001). Web. 9 August 2009.

Wertheimer, Jack. “The Orthodox Moment.” Commentary. 197.2 (1999): 18-24.

Yisraeli, Shaul. “Ceding Territory Because of Mortal Danger.” Tehumin. 10 (1989): 2946.

Yosef, Ovadia. "Ceding Territory of the Land of Israel in Order to Save Lives." Tehumim 10 (1989): 11-28.

Zussman, Yale. "How Much Do American Jews Support the Peace Process?" Middle East Quarterly 5.4 (1998): 3-12.

\section{Primary Sources}

1997 Annual Survey of American Jewish Opinion. (New York: American Jewish Committee, 1997).

1998 Annual Survey of American Jewish Opinion. (New York: American Jewish Committee, 1998).

1999 Annual Survey of American Jewish Opinion. (New York: American Jewish Committee, 1999).

2000 Annual Survey of American Jewish Opinion. (New York: American Jewish Committee, 2000). 
2001 Annual Survey of American Jewish Opinion. (New York: American Jewish Committee, 2001).

2002 Annual Survey of American Jewish Opinion. (New York: American Jewish Committee, 2001).

2003 Annual Survey of American Jewish Opinion. (New York: American Jewish Committee, 2001).

1990 National Jewish Population Survey. (New York: Council of Jewish Federations, 1990).

2000-20001 National Jewish Population Survey. (New York: United Jewish Communities, 2002).

"AJC On Israel Diaspora-Relations: A Policy Statement Adopted by the Board of Governors, February 11, 1995.” Web. 15 April 2009.

Ament, Jonathan. "Israel Connections and American Jews." (New York: United Jewish Communities, 2005).

“Bush’s Letter To U.S. Jews.” New York Times. 21 September 1991.

Cohen, Steven M. "Ties and Tensions: Ties And Tensions: An Update: The 1989 Survey of American Jewish Attitudes Toward Israel. (New York: American Jewish Committee, 1989).

"International Financial Aid to the Palestinian Authority Redirected to Terrorist Elements, 5 June 2002. Israel Defense Forces. 5 June 2002. Web. at April 2009.

"Jerusalem: City of Peace: A Statement To President Clinton From Christian Leaders," Churches for Middle East Peace, 6 March 1995. Web. 20 June 2009.

Eizenstat, Stuart. “Treasury Deputy Secretary Stuart E. Eizenstat Remark At The Van Leer Forum Jerusalem, Israel," 31 October 1999. U.S. Department of the Treasury. Web. 22 April 2009. Address.

"Excerpts From President Bush's News Session on Israeli Loan Guarantees." The New York Times. 13 September 1991.

"Fundamental Agreement Between The Holy See And The State Of Israel." Web. 30 June 2009.

“Jerusalem: City of Peace: A Statement To President Clinton From Christian Leaders," 
Churches for Middle East Peace, 6 March 1995.

"Highlights of the 1990 National Jewish Population Survey." (New York: Council of Jewish Federations, 1990).

Katz, Elihu Katz, Shlomit Levi and Hanna Levinsohn. A Portrait of Israeli Jewry 2000. (New York: Avichai Foundation and Israeli Democracy Institute, June 2002)

Kelner, Shaul, et. al. "Making Meaning: Participants' Experience of Birthright Israel." (Waltham, Mass.: Cohen Center for Modern Jewish Studies, 2000).

Mayer, Egon, Barry Kosmin and Ariela Keysar. American Jewish Identity Survey: 2001. (New York: The Graduate Center of the City University of New York, 2003)

"National Jewish Population Survey 2000-2001: Strengthen Challenge and Diversity in the American Jewish Population.” Web. 15 Jan. 2009.

Neeman Report on the Conversion Law. (Jerusalem: The Government of Israel Printing Office, 1998). Web. June 202009.

Newport, Frank and Joseph Carroll. "Republicans and Religious Americans Most Sympathetic To Israel.” (Gallup: Princeton, N.J., 27 March 2006).

"Opinion Poll: Israel and the Palestinians: American Impressions." The New York Times. 26, April 1998.

"Report of the Sharm el-Sheikh Fact Finding Committee." (Washington: U.S. Department of State, 2001). Web. 22 June 2009.

"Resolution on Jerusalem," adopted by the NJCRAC Executive Committee, 13 June 1994.

Protocol Concerning The Redeployment In Hebron. 17 January 1997. (Jerusalem: Government of Israel Printing Office, 1997). Web. 22 June 2009.

Saxe, Leonard, et. al. Birthright Israel Launch Evaluation: Preliminary Findings. August 2000. (Waltham, Mass: Maurice and Marilyn Cohen Center for Modern Jewish Studies, Brandeis University).

Sokhey, Anan Edward and Paul A. Djupe. "Rabbi Engagement With the Peace Process In The Middle East," 1 July 2005. Web. 12 July 2009.

"Statement on the Middle East Peace Process," adopted by the NJCRAC Annual Policy Conference, 21 February 1994. Web. 22 June 2009. 
"Statement on the Middle East Peace Process," adopted by the NJCRAC Executive Committee, 23 October, 1995. Web. 22 June 2009.

"Statement of Principles on Jewish-Arab Relations," adopted by the NCRAC Annual Plenum. 4 May 1995. Web. 22 June 2009.

"The Existing Basic Laws: Full Texts." (Jerusalem: Government of Israel Printing Office). Web. 9 August 2009.

"The Rabinnic Call for a Shared Jerusalem.” The Jewish Peace Lobby, 19 January 2000. Web. 9 August 2009.

Wertheimer, Jack, ed. In The Center: Conservative Synagogues and their Members. (Rutgers, N.J.: Rutgers University Press, 2000).

---. Conservative synagogues and their members: highlights of the North American study of 1995-96. (New York: Jewish Theological Seminary of America, 1996).

\section{$\underline{\text { Newspaper and Magazine Articles }}$}

Agha, Hussein and Robert Malley, "Camp David: The Tragedy of Errors." New York Review of Books. 9 Aug. 2001.

Mitchell, Alison, “The Israeli Vote: The Policy: Clinton Is Shaken, But Reaffirms Tie,” New York Times. 31 May 1996.

Arnold, Michael. “'Don't Legitimize Diaspora,' Israel's New President Warns." Forward. Internet edition. 15 September 2000. Web. 13 June 2009.

Berkman, Jacob. "Rallying The Troops: Protestors charge anti-Israel bias against The Sun.” Baltimore Jewish Times. 20 Oct. 2000, pp. 28-29.

---. "Student Spirit: Local college campuses grapple with the Middle East crisis," Baltimore Jewish Times. 20 Oct. 2000, pp. 34-35.

Berkofsky, Joe. "Population Study Poses Challenges," JTA Wire Service, 8 Oct. 2003.

Besser, James D. “What's Next For Jewish Groups?” Baltimore Jewish Times. 17, Sept., 1993, pp. 20-21.

---. Message For A Changing Era,” Baltimore Jewish Times. 16 Dec. 1994, p. 22.

“ZOA Leadership Fight Reflects Mideast Changes,” Baltimore Jewish Times. 10 Dec. 
1993, p. 31.

---. “Too Close For Comfort: The Clinton administration's embrace for Peres elicits cries of meddling and backlash fears if Netanyahu prevails." The Baltimore Jewish Times. 17 May 1996, p. 22.

---. "Power Trip: An Orthodox group's new office typifies the trend toward religious Jewish political activism.” Baltimore Jewish Times. 8 Jan. 1998, pp. 34-35.

---. "A Yeasty Mix: This year's UJA young leadership conference mixed Middle East politics with spiritual regeneration.” Baltimore Jewish Times. 27 March 1998, pp. 4243.

---. “Separation Anxiety,” Baltimore Jewish Times, 24 April 1998, pp. 54-55

---. Yawning At Zion,“ Baltimore Jewish Times, 23 April 1998, pp. 39-40.

---."Lessons Unlearned.” The Baltimore Jewish Times, 26 May 1999, pp. 36-37

---. "Behind the Wye Victory: Jewish groups played an important role - even in opposition of one another." Baltimore Jewish Times. 12 November 1999, pp. 34-35.

---."Fearless: Israel's new ambassador isn't wasting time in pushing his country's agenda - even if it irritates American Jews.” Baltimore Jewish Times. 25 Feb. 2000, p. 28.

---. "Lemon From Lemonade: American Jewish groups put the spin in high gear in the wake of the Camp David failure.” Baltimore Jewish Times. 28 July 2000, p. 26.

---. "Crisis For Left, Right, Center: Each part of American Jewry's pro-Israel spectrum needs new directions." Baltimore Jewish Times 13 Oct. 2000: 25, 39.

---. "The Hope Deficit: American Jewish leaders are left wondering what message to offer the rank and file about Israel." Baltimore Jewish Times 27 Oct. 2000, pp. 36-37.

---. "Soul Battles: American Jewish wrestle with their role in keeping Jerusalem and its Old City united under Jewish rule.” Baltimore Jewish Times 5 Jan. 2001, pp. 41.

---. “The Great Divide.” Baltimore Jewish Times 12 Jan. 2001, pp. 30-31.

---. “Selling Sharon.” Baltimore Jewish Times 9 Feb. 2001, pp. 34.

---. “Charm Offensive.” Baltimore Jewish Times 16 Feb. 2001, pp. 38-39.

Brinkley, Joel "Shamir Promises New Definition of Who Is A Jew," New York Times. 12 Nov. 1988. 
---. “Soviet Jews Leave At Record Pace, Mostly For Israel.” New York Times. 14 Dec. 1989.

Broadway, Bill. "The Evangelical-Israeli Connection,” Washington Post. 27 March 2004.

Broder, Jonathan. "Heeding The Call.” The Jerusalem Report. 29 March 1999, pp. 34-35.

Brozan, Nadine and Gustav Niebuhr, "Reform Jews Mirror Return to Ritual." The New York Times, 1 June 1999.

Chessler, Chaim. “Solidarity - At All Times,” Jerusalem Post. 30 Oct. 2000, p. 6.

Derfner, Larry. “A Wall Of Support,” Baltimore Jewish Times. 5 June 1998, pp. 36-37.

---. “The Americans Cometh,” Baltimore Jewish Times, 14 May 1999, p. 32.

---. "Secular Revolution: Ehud Barak has given up on Israel's religious parties and is pushing hard for an expanded secular base." Baltimore Jewish Times. 25 April 2000, pp. 33,35 .

---. "Secular Revolt: Ehud Barak pushes a new secular-religious formula." Baltimore Jewish Times. 22 Sept. 2000, p. 38, p. 40.

Dorf, Matthew. "Poll: We Like Barak,” Jewish Telegraphic Agency. 15 July 1999.

---. "Histrionics Over Peace Process Mark Palestinian Aid Hearing." Jewish Telegraphic Agency. 29 Sept. 1995.

Ephross, Peter. Times Boycotts Launched.” JTA Wire Service. 7 May 2001. Web. 5 August 2009.

Erlanger, Steven. "Netanyahu Airs Differences With Clinton On Peace Issues," New York Times. 10 July 1996.

---. “In Netanyahu, Congress Sees Familiar Spin.” New York Times. 11 July 1996.

Dexter Filkins, "The Sharon Victory: Support Mixed With Concern Among U.S. Jewish Groups.” New York Times. 7 Feb. 2001.

Feiden, Douglas. "Baltimore Balks At ZOA Proxy." 12 August 1994. The Forward, p. 1. Freedman, Robert O. “Israel At 50.” Baltimore Jewish Times, 24 April 1998, pp. 8, 12. 
Friedman, Thomas L. Friedman, "Israelis Bar Redefining Of A Jew, Posing Threat To Rule By Shamir," New York Times, 9 July 1987.

---, 'Rabin And Arafat Seal Their Accord As Clinton Applauds 'Brave Gamble.' The New York Times. 14 Sept. 1993.

Gregory, Joseph R. “Hassan II of Morocco Dies At 70.” New York Times. 24 July 1999.

Gilbert, Nina. "Barak, Shohat OK \$70 Million for Birthright Project.” Jerusalem Post. 13 Oct. 1999, p. 5.

Goldberg, J.J. “Love Letters,” Baltimore Jewish Times. 24 April 1998, pp. 56-57.

Julia Goldman, "G.A. Helps Bridge The Division Between Israeli and Diaspora Jews," Jewish Telegraphic Agency. 18 Nov. 1998.

Goodstein, Laurie, "Falwell Offers To Mobilize Churches To Oppose Israeli Pullback," Washington Post, 21 Jan. 1998.

---. “The Religion Issue: Bush's Jesus Day Is Called Insensitive and a Violation of the First Amendment." New York Times, 6 Aug. 2000.

---. “101 Rabbis Call for Sharing Temple Mount.” New York Times. 7 Dec. 2000

---. “Survey Find Slight Rise In Jews Intermarrying.” New York Times. 11 Sept. 2003

Greenberg, Joel. “Trips to Renew Jewish Ties Set Off Debate Over Costs," New York Times. 8 Jan. 2000.

Gross, Netty C. “The Kinship.” The Jerusalem Report, May 25, 1998, pp. 28-33.

Haberman, Clyde. "Rabin and Pro-Israel Group Off to Testy Start.” New York Times. 22 Aug. 1991.

---. “Assassination In Israel: American Jews, Leaders Lay Politics Aside To Mourn Death Of Rabin. New York Times. 5 Nov. 1995.

Harris, David Zev. "Melchior to Establish Unity Council Soon," Jerusalem Post, 6 Aug. 1999, p. 2-A.

Henry, Marilyn. “Melchior's Affirmative Views Charm Conference," Jerusalem Post. 19 Nov. 1999, p. 6-A.

---. “GA Ends With United Body, Divisive Issues,” Jerusalem Post. 21 Nov. 1999, p. 3.

Herz, David. "Staying Informed: The Internet allows for up-to-the-minute information on 
the Mideast crisis.” Baltimore Jewish Times. 20 Oct. 2000, pp. 32-33.

Hirsch, Rona "Call To Arms? Jewish and Arab-American leaders discuss the possibility of violence spreading to their communities." Baltimore Jewish Times 13 Oct. 2000, pp. 32-33.

Hoffman, Gil. “400 Visiting Diaspora Educators Say Katzav Has A Lot To Learn.” The Jerusalem Post. Internet Edition. 14 Sept. 2000. Web. 22 February 2009.

Horovitz, David, Leslie Susser and Vince Beisser. "Who'll Be A Jew?" The Jerusalem Report. 12 December 1996. Web. 25 June 2009, pp. 12-16.

"In The Same Boat,” Editorial. Jerusalem Post. 19 Nov. 1999.

"In the Words of Camp David Negotiators: 'Unprecedented in Both Scope and Detail."' New York Times. 26 July 2000.

Itzkowitz, Shani. "At One With Israel: Thousands gathered at Chizuk Amuno last week to express their solidarity with Israel." Baltimore Jewish Times 27 Oct. 2000, pp. 10, 12.

Jerusalem Post Staff. “1,000 Here On Lengthy Support Mission,” Jerusalem Post. 31 Oct. 2000, p. 4.

---. “Solidarity Missions March to Western Wall,” Jerusalem Post. 1 Nov. 2000, p. 2.

Jordan, Michael J. "For Reform Head, Nixing Israel Trips Is Just Latest Controversy." Jewish Telegraphic Agency. 15 June 2001.

John Kifner, "Clinton Hints That He Is Ready to Move Embassy to Jerusalem." The New York Times. 29 July 2000.

---. "Tale of Two Uprisings: This Time, the Palestinians Have Territory, and Guns." The New York Times. 18 Nov. 2000.

Kleinfeld, N.R. Kleinfield. "Netanyahu, in New York, Promotes His Views on Peace and Invites Investments,” New York Times. 12 July 1996.

Landau, David, "U.S.-Jewish Groups Battle Orthodox-Only Conversion Law," Jewish Telegraphic Agency, 1 Dec. 1995.

MacFarquhar, Neil. “300 Rabbis In U.S. Group Say Jerusalem is Shareable.” The New York Times, 20 Jan. 2000.

Magida, Arthur. “A New Day For Interfaith Talks?” Baltimore Jewish Times, 18 Oct. 
1993, pp. 46, 48.

---. “The Peace Dividend,” the Baltimore Jewish Times, 12 Nov. 1993, pp. 32-33.

Mandel, Saundra. "Successful Conference Spawns New Orthodox Feminist Alliance." Jewish Telegraphic Agency, 4 July 1997.

---. "Modern Orthodox Find Community Amid Struggle to Define an Identity." Jewish Telegraphic Agency, 16 Feb. 1999.

Mcfadden, Robert D. “Abruptly, a U.S. Student In Mideast Turmoil's Grip.” New York Times. 7 Oct. 2000.

---. "The Man In The News: A Man of Steady Habits - Joseph Isador Lieberman." New York Times, 8 Aug. 2000.

Mitchell, Alison. "Rabin Rebukes U.S. Jewish Groups on Lobbying.” 30 Sept. 1995. New York Times.

Mohr, Charles. "Senate, 52-48, Supports Reagan on AWACS Jet Sale to Saudis; Heavy Lobbying Tips Key Votes.” New York Times. 29 Oct. 1981.

Nagourney, Adam. "The World: For American Jews, Israeli Politics Is A World Away," New York Times. 16 May 1999.

Niebhur, Gustav, "Lieberman Is Asked To Stop Invoking Faith In Campaign.” 29 Aug. 2000.

New York Times.

---. "Religion Journal: Ascent of Lieberman Inspires Sermon Ideas," New York Times. 30 Sept. 2000

“Partnership 2000 Supplement,” Haaretz. 9 Oct. 2000.

Pash, Barbara. "Foundations of Giving: Jewish philanthropic organizations are changing the face of Baltimore - and the world." Baltimore Jewish Times. 19 Nov. 1999, pp. 5056.

Pear, Robert, "U.S. Drafts Plan to Curb Admission of Soviet Jews." New York Times. 3 Sept. 1989

Jane Perlez, "Clinton Sends Mideast Sides back Home With Deadline," New York Times. 24 Dec. 2000.

Pipes, Daniel. “A View Of U.S. Jews.” The Jerusalem Post. Internet Edition. 28 Sept. 
1999. Web. 27 July 2009.

Pomerance, Rachel. "New Solidarity Initiative Launched." Jewish Telegraphic Agency. 30 Nov. 2000.

Reuters, "Baker Agrees To Housing Aid For The Israelis.” New York Times. 3 Oct. 1990.

Rosenthal, Andrew. "Bush Acts To Calm Israel Aid Uproar.” New York Times. 21 Sept. 1991.

Rifkin, Ira. "BJC Accepts Peace Now,” Baltimore Jewish Times, 22 Dec. 1993.

Rosenberg, M.J., “Winners And Losers?” IPF Friday \# 7, 22 July 2000. Web 12 July 2009.

Rothenberg, Randall. "Newspaper Faults Columnist For Remarks On Jews.” The New York Times. 20 Sept. 1990.

Rowe, Debbie, "Jewish Agency Takes Steps Aimed at Winning Federations'

Confidence," Jewish Telegraphic Agency.” 2 July 1997.

Rubin, Neil. “Peace: Are We Ready?” Baltimore Jewish Times. 24 Dec. 1999, pp. 34-39.

---. “Unity’s New Warrior.” Baltimore Jewish Times, 7 Jan. 2000, pp. 33-34.

---.“Coming Full Circle: Through Partnership 2000, can Baltimore's Jewish community re-energize its personal ties to Israel?" Baltimore Jewish Times, 10 March 2000, pp. 4246.

---“Left Turn: Baltimore's longtime Mideast peace advocates are distressed, but hold to their principles." Baltimore Jewish Times 20 Oct. 2000, pp. 13-14.

---. "Faulty Print, Frayed Footage: Is the media really biased against Israel, or is it just a product of its limitations?" Baltimore Jewish Times 27 Oct. 2000, pp. 29-31.

---. "Standing With Israel: Baltimore's presence on whirlwind national solidarity tour of Israel is strong." Baltimore Jewish Times 10 Nov. 2000, pp. 42-43, 56.

---. “Rallying Solidarity,” Baltimore Jewish Times. 5 Nov. 2000, pp. 14-15.

---. The Wall Between Us: How close are American Jews to the crisis in Israel?" Baltimore Jewish Times 19 Jan. 2001, pp. 42-45.

Sachs, Susan. "Arabs Strive for New Consensus On an Israeli-Palestinian Treaty," The New York Times. 5 Aug. 2000. 
Schrag, Carl. "Barak to Address G.A. in Chicago Tonight," Jerusalem Post. 13 Nov. 2000.

Schultz, Kenneth. "Collaboration Is Name of Game in World of Jewish Philanthropy." Jewish Telegraphic Agency, 29 April 1999.

Sciolino, Elaine Sciolino, "U.S. To Contribute \$250 Million In Aid For Palestinians," The New York Times. 21 Sept. 1993.

----. "Assassination in Israel: Washington; American Officials Warmly Remember Rabin As A Friend They Came To Trust Deeply." New York Times. 6 Nov. 1995.

Schmemann, Serge, “The Israeli Vote: Man In The News: The 'American' Premier," The New York Times, 1 June 1996.

---. “'Who’s a Jew’ Puzzle Gets More Tangled,” New York Times, 27 Jan. 1998.

---“Israel's Chief Rabbis Reject Call By Non-Orthodox on Conversion," New York Times, 10 Feb. 1998.

Schemo, Diana Jean. "Holocaust Museum Hailed As Sacred Debt to Dead." The New York Times. 23 April 1993.

---. "Barak, Addressing American Jews, Stresses Israel's Yearning for Peace." New York Times. 21 Nov. 1999.

Schleifer, Yigal. "U.S. Jews Mourn The Absence of Dialogue With Arab Americans." The Jerusalem Report. 6 Nov. 2000, p. 5.

Seelye, Katharine Q. "Relocating Embassy in Israel: Move Could Backfire on Dole." The New York Times. 18 May 1995.

Shipler, David K. "The Golan Heights Annexed By Israel In An Abrupt Move.” The New York Times, 15 Dec. 1981.

---. "Begin Agrees To Establish A Panel To Investigate The Beirut Massacre.” The New York Times. 29 Sept. 1982.

Silver, Eric. "'Arab CNN': A 24-hour Mideast television news station soars in the wake of the Second intifada." Baltimore Jewish Times. 8 Dec. 2000, p. 38.

Sol Stern, "Menachem Begin vs. the Jewish Lobby." New York Magazine. 24 April 1978, pp. 59-63. 
Sontag, Deborah. "Non-Orthodox Rabbis Win A Court Skirmish in Israel," New York Times, 13 Dec. 1998.

---. “Israel's 'Who Is a Jew’ Perennial Sprouts Anew,” New York Times, 7 Jan. 1999.

---. “Two Candidates Quit In Israel on Day Before Elections,” New York Times. 17 May 1999

---. "Barak's Coalition Crumbles On Eve Of Summit Talks.” New York Times, 10 July 2000.

---. "Israel Is Studying Negotiating Ideas Once Unthinkable," New York Times. 23 Sept. 2000.

---. "Huge Rally In Jerusalem Protests U.S. Proposal to Divide Sovereignty." The New York Times. 9 Jan. 2001

Steinfels, Peter. “In Memorial For Rabin, Jews Forge Fragile Unity. New York Times. 8 Dec. 1995.

Stout, David. "The Israeli Vote: In America: In Reactions, Jewish Groups Echo the Split Of the Results." New York Times. 1 June 1996.

Susser, Leslie. "Brief Encounter.” The Jerusalem Report. 7 June 1999, p. 11.

Swarns, Rachel L., "Netanyahu Stresses Cultural Bonds for Jews in New York and Israel.” The New York Times. 14 July 1996.

Tigay, Chanan . “A New Trend in Jewish Giving?” Jewish Telegraphic Agency, 30 Nov. 1999.

Troy, Gil. “Birthright Israel - Why I Was Wrong.” Moment, May 2000, p. 54.

Wagner, Donald. "Evangelicals and Israel: Theological Roots of a Political Alliance," in Christian Century, 4 Nov. 1998, pp. 1020-1026.

Waldman. Amy. "Israel’s Leader Highly Praises Hillary Clinton,” New York Times. 22 Nov. 1999.

Weinberg, David. “Melchior's Promising Moderation,” Jerusalem Post, 14 Nov. 1999, p. 6.

Weiner, Julie. "Israel Returns to G.A. Spotlight.” Jewish Telegraphic Agency, 1 Nov. 2000 . 
---. "YU Confronts Fault Lines of Modern Orthodoxy." Jewish Telegraphic Agency, 20 March 2001.

"World News Briefs: Syrian Foreign Minister Meets American Jews," New York Times. 7 Oct. 1994.

\section{$\underline{\text { Press Releases }}$}

Anti-Defamation League. “ADL To Senator Lieberman: Keep Emphasis On Religion Out Of Campaign.” 28 Aug. 2000.

Orthodox Union Institute for Public Affairs. "Orthodox Union Criticized Vatican-P.A. Pact On Jerusalem.” 23 Feb. 2000.

Union of American Hebrew Congregations. "Nation's Largest Jewish Organization Reacts to End of Camp David Summit." 25 July 2000.

---. "Reform Jewish Movement Launches Major Mideast Peace \& Justice Initiative.” 4 Dec. 2000.

Union of Orthodox Jewish Congregations of America. "OU Congratulates Prime Minister-elect Barak on Election Victory.” 24 May 1999.

---. “OU Urges Preservation of Jewish Character of State of Israel.” 25 Sept. 2000.

\section{Speeches}

Barak, Ehud "Excerpts from Remarks by Prime Minister Ehud Barak to the General Assembly of The United Jewish Communities.” Chicago. 13 Nov. 2000. Address.

Bayme, Steven. "Changing Patterns in Israel-Diaspora Relations." (New York: American Jewish Committee, 1994). American Jewish Press Association. San Francisco. Address.

Clinton, Bill. "Eulogy for the Late Prime Minister and Defense Minister Yitzhak Rabin by U.S. President Bill Clinton.” Jerusalem. 6 November 1995. Address.

"In The Words of Camp David Negotiators: 'Unprecedented in Both Scope and Detail," New York Times. 26 July 2000.

Netanyahu, Binyamin. "Address by Prime Minister Netanyahu to the Council of Jewish Federations General Assembly, 15 November 1996.” Seattle, Washington. Address. 
---."Address by Prime Minister Benjamin Netanyahu at the General Assembly of the American Council of Jewish Federations.” Indianapolis. 16 November 1997. Address.

---. "Address by Prime Minister Benjamin Netanyahu to the UJA-CJA General Assembly.” Jerusalem. 16 Nov. 1998. Address.

Rabin, Yitzhak. "Address by Prime Minister Rabin to the $32^{\text {nd }}$ Zionist Congress -30 July 1992." Address.

---. "Address by Prime Minister Rabin to the General Assembly of the Council of Jewish Federations-Montreal-18 November 1993.” 18 Nov. 1993. Address.

---. “Address by Prime Minister Rabin to AIPAC Conference - 21 March 1993.” Washington, D.C. Address.

Yoffie, Eric. H. “Installation Sermon.” Temple Shaarey Tefila, New York City. 8 June 1996. Address.

---. “An Address to the $33^{\text {rd }}$ Zionist Congress.” Jerusalem. 24 December 1997. Address.

---. The Masks Are Off: Palestinians, Israelis, And The Problem Of Peace.” UAHC National Board Meeting, Temple Tifereth Israel, Cleveland, Ohio. 1 June 2001. Address.

---. "We Don't Make Political Statements With Children: Remarks to the UAHC Board of Trustees on the Suspension of Trips to Israel." Jerusalem. 2 June 2001. Address. 


\section{CURRICULUM VITA}

NAME: Neil Rubin

PERMANENT ADDRESS: 2419 Lightfoot Drive, Baltimore, Md. 21209

PROGRAM OF STUDY: History/Political Science

DEGREE AND DATE TO BE CONFERRRED: Doctorate of Philosophy, 2009

Secondary education: Pikesville High School, Baltimore, Md., May 1981

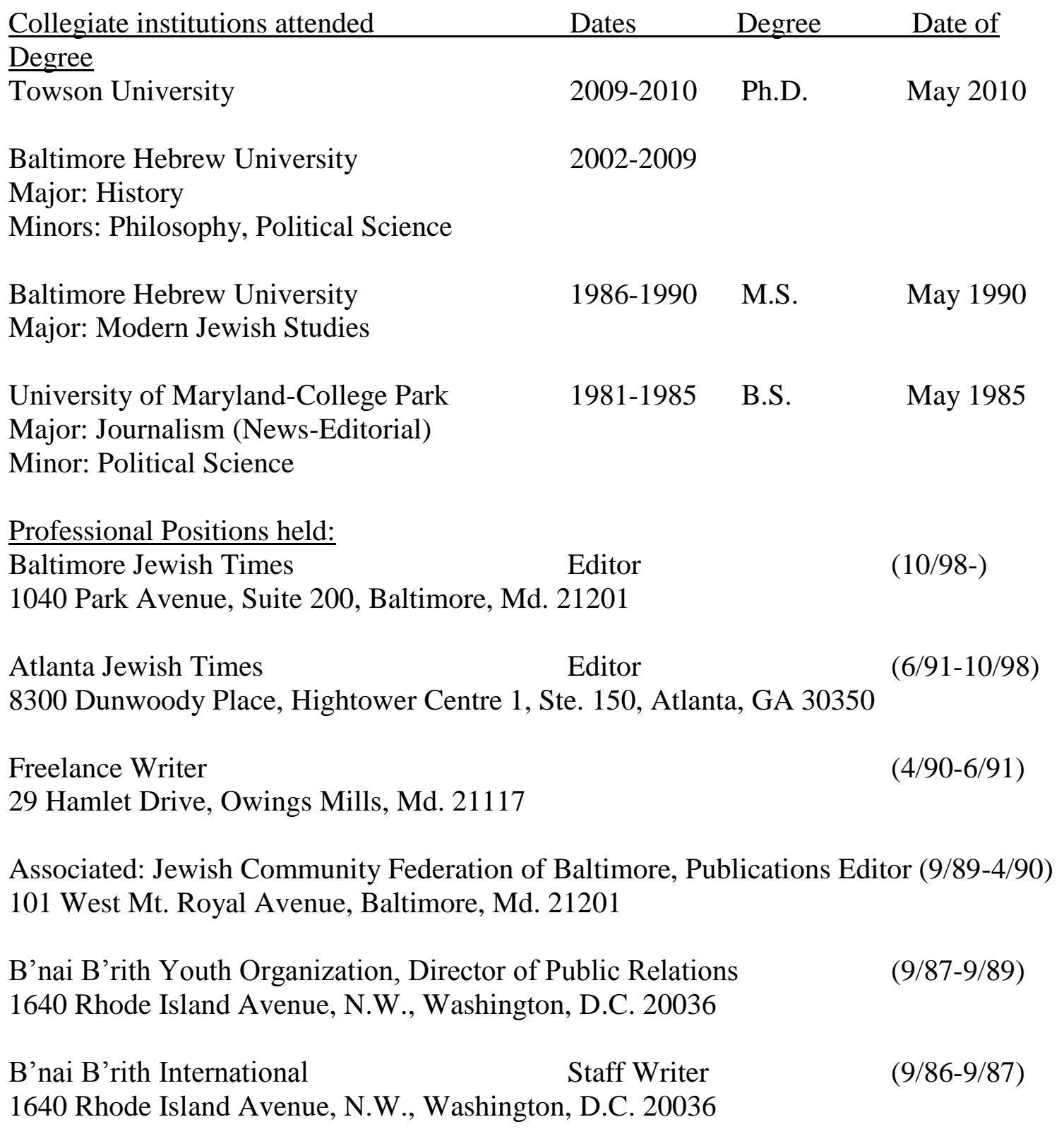

